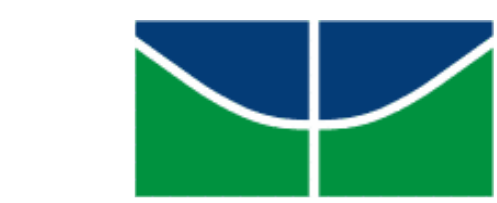

UNIVERSIDADE DE BRASÍLIA

INSTITUTO DE PSICOLOGIA

Programa de Processos de Desenvolvimento Humano e Saúde

CARTOGRAFIA DAS PRÁTICAS DE SUBJETIVAÇÃO

EM EXPERIÊNCIAS TRANS

Polianne Delmondez

Brasília, março de 2017 


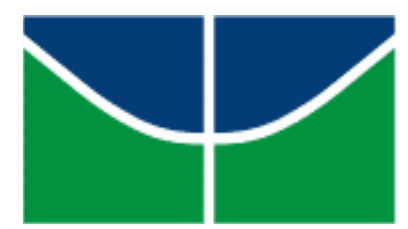

UNIVERSIDADE DE BRASÍLIA

INSTITUTO DE PSICOLOGIA

Programa de Pós-graduação em Processos de Desenvolvimento Humano e Saúde

\title{
CARTOGRAFIA DAS PRÁTICAS DE SUBJETIVAÇÃO EM EXPERIÊNCIAS TRANS
}

\author{
Polianne Delmondez
}

Tese apresentada ao Instituto de Psicologia da Universidade de Brasília, como requisito parcial à obtenção do título de Doutora em Processos de Desenvolvimento Humano e Saúde, na área de Desenvolvimento Humano e Educação.

ORIENTADORA: Profa. Dra. Silviane Bonaccorsi Barbato 
Ficha catalográfica elaborada automaticamente, com os dados fornecidos pelo(a) autor(a)

Delmondez, Polianne

Cartografia de práticas de subjetivação em

DD359c experiências trans / Polianne Delmondez; orientador Silviane Barbato; co-orientador Pedro Paulo Bicalho. -- Brasília, 2017. $145 \mathrm{p}$.

Tese (Doutorado - Doutorado em Processos de Desenvolvimento Humano e Saúde) -- Universidade de Brasília, 2017.

1. Metodologia da cartografia. 2. Processos de produção da subjetividade. 3. Transgeneridade e transexualidade. 4. Desenvolvimento psicológico. 5. Práticas e discursos psicológicos. I. Barbato, Silviane, orient. II. Bicalho, Pedro Paulo, co orient. III. Título. 
UNIVERSIDADE DE BRASÍLIA

INSTITUTO DE PSICOLOGIA

TESE DE DOUTORADO APROVADA PELA SEGUINTE BANCA

EXAMINADORA:

Profa. Dra. Silviane Bonaccorsi Barbato - Presidente

Universidade de Brasília

Prof. Dr. Pedro Paulo Gastalho de Bicalho - Membro

Universidade Federal do Rio de Janeiro

Prof. Dr. Wanderson Flor do Nascimento - Membro

Universidade de Brasília

Profa. Dra. Lúcia Helena C. Zabotto Pulino - Membro

Universidade de Brasília

Profa. Dra. Tatiana Lionço - Membro

Universidade de Brasília

Profa. Dra. Ondina Pena Pereira - Suplente

Universidade Católica de Brasília

Brasília, março de 2017 


\section{UMA CARTA DE AGRADECIMENTOS}

No princípio: os afetos. Não há nada melhor do que começar o texto por aqui. Ao longo de todo o caminho, diga-se quatro anos (uma sensação de que foram longos e, ao mesmo tempo, curtos, talvez fuja de qualquer cronologia pontual), houve um instável rebuliço de novidades, dúvidas, ambições, conquistas. Estas se deram, principalmente, pela minha necessidade de tecer parceiras. Entendi que "o pensar" só se torna mais potente, ou até possível, quando se faz associações entre pessoas e suas ideias.

Quem é o sujeito da pesquisa? Como ele se auto finaliza a partir de suas hesitações? Não é fácil fazer um doutorado, principalmente, quando o nível de auto-exigência é bastante alto. Escrever uma carta de agradecimentos é também se colocar como um ser humano que também faz pesquisa e se mantém em contato direto com a vida.

Tão trabalhada como conceito ao longo do texto, é preciso perguntar o que, então, significa propriamente a vida. Qual é seu teor? Sua natureza? Para mim, trata-se de "uma nova concepção de vida", uma vontade de potência, tal como afirma Nietzsche. Vontade no sentido de um impulso ou uma tendência, e potência, por sua vez, no mesmo campo semântico que produzir, criar ou formar. A minha experiência passou a ser critério de avaliação porque permitiu dar sentido a elementos antes não observados. Assim, foram mobilizadas forças criadoras advindas de meus processos de aprendizagem, de afetos e de perceptos.

Neste doutorado, fui feliz a cada processo e a cada encontro. Teci muitas amizades, que de um modo ou de outro, contribuíram para que as minhas ideias pudessem nascer e ganhar corpo.

Aos meus pais Vênus e Evandro, em primeiro lugar, por me ensinarem valores como responsabilidade e ética, por estimularem minha liberdade e o impulso pela criatividade.

Ao Samir, pelo cuidado, amor e oportunidade de me fazer sonhar.

Às minhas irmãs Christiane, Keyfanne e irmão Evandro, pelo respeito e solidariedade.

À minha orientadora Silviane, pelas perguntas desafiadoras e pela alegria.

Ao meu orientador do período sanduíche, Pedro Paulo, pelo acolhimento, inteligência e parceria.

Aos grupos de pesquisa do GPPCult da UnB e GrupoPPPos da UFRJ, pelas trocas de ideias.

Às/aos amigas/os (pesquisadoras/es) que me acompanharam nessa jornada de me tornar doutora, Lúcia Pulino, Marcus de Jesus, Zahra, Wanderson, Ana Paula Carlucci, Nicole Zanetti, Jéssica, Nadielle, Tainá, Roberta, Malu, Diana, André Santos, Ju Lopes, Lucas Seco, Jef Cardoli.

Às pessoas trans, pela coragem de dizer e viver a verdade de suas experiências. Dedico agradecimentos, em especial, às/aos participantes da pesquisa pela disposição em colaborar com a realização deste estudo.

Ao CNPq, pela bolsa de doutorado como apoio financeiro. 
"E quanto a você?

Quais são as suas máquinas desejantes?

Num difícil e belo texto, Marx invocava a necessidade de pensar a sexualidade humana não apenas como uma relação entre dois sexos humanos, masculino e feminino, mas como uma relação entre "o sexo humano e o sexo não humano", ele, evidentemente, não se refere aos animais, mas ao que há de não humano na sexualidade humana: as máquinas de desejo".

Gilles Deleuze (2004) in A Ilha Deserta e outros textos

"Nós nos dirigimos aos inconscientes que protestam.

Buscamos aliados. Precisamos de aliados".

Gilles Deleuze (1992) in Conversações

In this short life That only (merely) last an hour How much (how little) is with our power 


\section{RESUMO}

Essa tese analisa como as pessoas trans dão sentido a sua experiência de subjetivação, ou seja, como constroem explicações acerca de si, do outro e do mundo, levando-se em consideração as dimensões envolvidas no seu desenvolvimento psicológico. Assim, a pesquisa foi realizada a partir das narrativas e das argumentações de pessoas que vivenciam a experiência da transgeneridade e da transexualidade, com foco em processos de autorreflexividade e de autorregulação psíquica diante da experiência. A perspectiva pósestruturalista de M. Foucault, G. Deleuze e J. Butler fornecem instrumentos conceituais para pensar como as subjetividades têm sido produzidas no espaço-tempo contemporâneo. Podese dizer que a construção do saber acerca das experiências trans está imersa numa série de aparatos técnico-discursivos que visam ditar uma verdade sobre quem é e como deveria viver. Nesse sentido, o objetivo é tecer um diagnóstico contemporâneo dos regimes de verdade existentes no dispositivo da transexualidade que, inclusive, está presente nas práticas e nos discursos psicológicos, e historicamente tem incitado e formado determinadas práticas de produção de sujeitos. A constituição das subjetividades está relacionada ao modo como o dispositivo da transexualidade, como um regime discursivo de poder-saber, também se reproduz nas práticas de subjetivação de sujeitos trans. Por outro lado, na contemporaneidade, há a emergência de sujeitos políticos que se articulam coletivamente e propõem novas possibilidades de reconhecimento social e de cidadania. Todo o percurso teórico e metodológico baseou-se cartografia, com o desenvolvimento da política da escrita enquanto poiesis para acompanhar os campos de força e a processualidade da investigação. Além disso, a análise de dispositivos e de seus desdobramentos, em analisadores, revelouse essencial, como, por exemplo, as políticas da amizade observadas durante a prática de pesquisa com as/os participantes. A investigação empírica foi realizada em encontros coletivos e individuais e subdividiu-se em três momentos principais. No primeiro momento, foi acompanhada uma prática profissional em psicologia; no segundo, foram feitas observações do movimento social de homens trans e LGBT; no terceiro, envolveu a participação voluntária de seis transexuais (trans binários e não-binários) em encontros de entrevistas nas modalidades narrativas e episódicas. A análise do dispositivo da transexualidade tem evidenciado como as práticas de si podem se desenvolver em técnicas de autoprodução a partir de resistências às hegemonias cisheteronormativas e ao binarismo de gênero, que são modos de governamentalidade. Com este estudo, foi possível propor uma nova compreensão sobre a relação constituinte entre gênero e processos de subjetivação, situado no âmbito das experiências trans, e, assim, permitiu a tessitura de um saber psicológico na perspectiva da despatologização.

Palavras-chave: cartografia; práticas de subjetivação; experiências trans. 


\begin{abstract}
This thesis analyzes how trans individuals give meaning to their experience of subjectivation - how they construct explanations about themselves, others and the world taking into consideration the dimensions involved in their psychological development. The research is based on the narratives of people who experience transgender and transsexuality, focusing on the processes of self-reflexivity and psychic self-regulation arising out of experience. The poststructuralist perspectives of M. Foucault, G. Deleuze and J. Butler provide conceptual tools for thinking about how these subjectivities are produced. Using these tools, this thesis argues that the construction of knowledge about trans experiences occurs in a series of technical-discursive assemblages that aim to dictate a truth about who someone is and how they should live. In this sense, the objective of the thesis is to provide a contemporary diagnosis of the regimes of truth that exist in the transsexual assemblage, which is present in psychological practices and discourses, and historically has incited and shaped certain practices of subject production. The constitution of subjectivities is related to the way the assemblage of transsexuality, as a discursive regime of power-knowledge, also reproduces itself in the practices of subjectivation of trans subjects. On the other hand, in this context, the emergence of political subjects that are collectively articulated and propose new possibilities for social recognition and citizenship. The entire theoretical and methodological framework is based on cartography, with the development of a politics of writing as poiesis to accompany the fields of force and procedures of the investigation. Further, the analysis of assemblages and their unfolding proved to be essential, as, for example, the politics of friendship was observed during the research practice with the subjects. The empirical investigation was carried out in collective and individual meetings and subdivided into three main moments. First, it was accompanied by a professional and research practice in psychology; second, observations were made of the trans and LGBT social movements; third, narrative and episodic interviews were conducted involving the voluntary participation of six transsexuals (trans binaries and non-binaries). The analysis of the assemblage of transsexuality has shown how the practices of the self can develop in techniques of self-production out of resistances to cisheteronormative hegemonies and gender binarism as modes of governmentality. With this study, it was possible to propose a new understanding of the mutually constituting relationship between gender and processes of subjectivation, situated within the scope of trans experiences, and, thus created psychological knowledge from the perspective of depathologization.
\end{abstract}

Key-words: mapping; subjectivation practices; transgender experiences. 


\section{LISTA DE DIAGRAMAS}

DIAGRAMA 1. Isso não é um cachimbo por Magritte

DIAGRAMA 2. O diagrama de Foucault

DIAGRAMA 3: Desenvolvimento psicológico numa perspectiva processual 


\section{SUMÁRIO}

Introdução: uma chave de leitura $\quad 12$

$\begin{array}{ll}\text { Objetivos da pesquisa } & 21\end{array}$

Fundamentação teórica $\quad 22$

Cartografia dos processos de subjetivação 22

$1.1 \mathrm{O}$ que são práticas de subjetivação? 34

1.2 Memória e o tempo dos processos de subjetivação 45

1.3 Gênero e as práticas de subjetivação 53

Produção de novas subjetividades 63

$\begin{array}{ll}2.1 \mathrm{O} \text { dispositivo da transexualidade e suas racionalidades } & 67\end{array}$

2.2 O lugar da Psicologia no debate sobre as experiências e os estudos transgêneros 77

Método: a oficina da pesquisa $\quad 85$

Poiesis: a técnica processual $\quad 85$

3.1 Cuidado ético-institucional $\quad 87$

3.2 Descrição espaço-temporal do processo de pesquisa 88

3.3 Quem são os sujeitos participantes da pesquisa? $\quad 89$

3.4 Como foi possível engajar o campo de pesquisa? 89

3.5 Dispositivos da pesquisa: instrumentais, operacionais e teórico-analíticos $\quad 90$

Analisadores e diagramas $\quad 91$

3.6 Procedimentos de construção e de análise das informações 91

- Análise do diário de campo da pesquisadora $\quad 91$

- Análise das entrevistas narrativas e episódicas $\quad 91$

\section{Resultados e discussão}

Os resultados do experimento ou as imagens da experiência 94

4.1 Análise de implicações e avaliação de efeitos 97

I. Do diário de bordo $\quad 97$

a. As memórias da cartógrafa $\quad 98$

b. A pesquisadora-participante da cartografia 101

II. Da prática de pesquisa: confiança na pesquisadora 104

a. Políticas da amizade na prática de pesquisa com pessoas trans 104

b. Linhas de visibilidade do TCLE: sobre o próprio nome 105

4.2 Cartografia de práticas de subjetivação 106

$\begin{array}{ll}\text { a. Narrativas das experiências trans } & 108\end{array}$

$\begin{array}{ll}\text { I. Dan } & 109\end{array}$ 
II. Jackie 111

III. Roberto 113

IV. João 115

V. Lee 117

$\begin{array}{ll}\text { VI. Gustavo } & 119\end{array}$

b. Desenvolvimento, gênero e processos de subjetivação 121

$\begin{array}{lr}\text { Considerações finais } & 129\end{array}$

Referências bibliográficas 132

$\begin{array}{ll}\text { Anexo1 } & 144\end{array}$

$\begin{array}{ll}\text { Anexo } 2 & 145\end{array}$ 


\section{INTRODUÇÃO: UMA CHAVE DE LEITURA}

Nesta tese de doutorado foram traçadas coordenadas para uma imersão na experiência de pesquisa. Durante o trajeto desenhou-se uma cartografia das práticas de produção da subjetividade no espaço-tempo contemporâneo. Nesse sentido, o cartografar possibilitou a idealização de um projeto teórico-metodológico para psicologia do desenvolvimento numa perspectiva pósestruturalista e crítica. A processualidade configurou-se como o principal modus operandi tanto do campo de pesquisa como do método numa agência de critérios processuais entre teoria, técnica e acontecimento.

O mencionado cronotopo $^{l}$ foi constituído pelas imagens dos processos de subjetivação dentro de uma determinada geografia. Este delineamento implicou o esboço de planos coexistentes a paisagem investigada e sugeriu a existência de regimes de verdade, a partir de articulações entre sujeitos, sistemas de signos, dispositivos técnicos e institucionais (Deleuze \& Guattari, 2000; Guattari, 2008). Esse modo de fazer pesquisa entende que os objetos de investigação em psicologia estão circunscritos numa dimensão histórica transitória em constante tensão e inacabamento.

Nesse sentido, houve a preocupação da cartógrafa em localizar as informações da pesquisa devido ao seu caráter de provisoriedade. A ideia é questionar as generalizações e as essencializações durante as análises sem cair num relativismo epistemológico. No ato de cartografar, tempo e espaço foram tomados como elementos indissociáveis: duração, velocidades e movimentos passaram a ser percebidos como índices do tempo que se desvelam no espaço (Bakhtin, 2011; Deleuze, 2006). Tempo e espaço constroem as imagens de uma realidade que pode tensionar um novo cronotopo, numa coexistência entre planos sobrepostos, onde um passa a se incorporar ao outro (Bakhtin, 2010; 2011).

Assim, notou-se que cada período histórico traz consigo uma concepção específica de humanidade, cada novo tempo corresponde a um modo diferente de produzir-se como humano. $\mathrm{O}$ processo de transformação no ser dos sujeitos implica uma variação no espaço e no tempo e novas articulações: o desenrolar de realidades possíveis, seus campos de força ${ }^{2}$ e as heterogêneses de fabricação de humano (Guattari, 2008; Haraway, 2009; Preciado, 2014).

A prática de pesquisa com cartografia é, portanto, desafiada a lidar com eventos, estados de

1 Deriva das palavras gregas cronos e topo, que significam, respectivamente, tempo e lugar. Atua neste texto como sinônimo da expressão espaço-tempo.

2 Compreende-se que "campos de força" significa o poder de transformação sobre a realidade e implica a ação de uma força sobre a outra, "que está no próprio processo de constituição do mundo" (César, Silva \& Bicalho, 2014, p. 161). A dialética ou a dialogia, que são noções diferentes, podem ser exemplos de vetores de força. Enquanto a dialética é um método lógico de síntese ou de superação entre teses (ou de vetores de força), a dialogia é o confronto de vozes e de sistemas de valores em que se posicionam os mais variados pontos de vista dentro de um campo de visão (Bakhtin, 2011), ou seja, os vetores de força se movimentam de forma múltipla, em diferentes direções, em um mesmo plano de análise. 
transitoriedade, dispositivos, processos de subjetivação. Nesse sentido, a/o cartógrafa/o tem consciência de que as estratégias de escrita fornecem o principal suporte para manejar estados de movimento e repouso durante todos os momentos da investigação. Deleuze e Guattari (2000) reforçam que "escrever nada tem a ver com significar, mas com agrimensar, cartografar, mesmo que sejam regiões ainda por vir" (p. 5-6).

Eis o exercício e o estilo da/o cartógrafa/o: pensar com imagens, capturar formas, delimitar os enquadres ou ainda construir os diagramas. Assim, após os recortes feitos na delimitação do problema, nas idas ao campo, no modo de lidar com as informações e na construção das análises, a escrita teve a principal função de garantir vida ao processo realizado. Há de se considerar que o texto só ganhou potência quanto mais conexões foram realizadas entre todas as etapas da investigação, por isso o escrever teve a intenção de produzir acontecimentos e mobilizar afetos na tentativa de agenciar a/o leitora/or.

O principal aforisma das pesquisas com cartografia é a de pesquisar o que está em processo, sendo necessário manter o caráter processual dos "objetos" " durante a análise. Pesquisadoras/es que não conhecem este modo de fazer pesquisa poderiam pensar que isto não é possível, pois os dados ficariam cristalizados no papel após a finalização tanto da pesquisa de campo como da escrita final da tese. Na cartografia, como o foco não é reproduzir dados e objetos prévios ou representar mundos, a processualidade visa promover agenciamentos com o fora do texto, "um fora suficiente com o qual ele possa agenciar no heterogêneo" (Deleuze \& Guattari, 2000, p. 33), no intuito de tornar o pensar polifônico e coletivo.

Segundo este critério, o trabalho não finaliza em si mesmo, pois pode, sempre que possível, tornar-se outro. As/os leitoras/es assumem a importância de propiciar ressonâncias ou de desestabilizar o texto, por isso são convidadas/os a participar da jornada. Escritora/or e leitora/or são incitadas/os a performar, juntos, uma oficina de escrever-COM. Surge, portanto, a questão de como atraí-las/os a colaborar com o processo.

Pode-se dizer que, a princípio, toda pesquisa requer a concepção de uma determinada política de escrita e de tecnologias metodológicas. Estas funcionam segundo zonas de implicação (Lourau, 1993; Deleuze, 2006), pois qualquer saber como prática situada está sempre implicado: o modo como a/o pesquisadora/or compreende a si, o outro e o mundo gera efeitos na sua escrita, produz subjetividades e marca o seu lugar de fala. Conforme a política de escrita aqui desenvolvida, não há possibilidade de conceber sujeitos na/da práxis sem implicação. Além disso, a implicação diz respeito aos movimentos realizados para descrever relações da/o pesquisadora/or e de seu pesquisar, num campo de exterioridade: é um/a sujeito/a, ao mesmo tempo, interessado/a e implicado/a, é pesquisador/a e pesquisado/a, é analisador/a e analisado/a, o que inclui, inevitavelmente, a sua auto-

3 A noção de "objeto de estudo" foi ressignificado pela cartografia como campo problemático. Pode-se dizer que, para a cartografia, sujeito e objeto são elementos interdependentes e, portanto, são identificados como partes integrantes de um campo problemático durante o processo da investigação. 
análise imersa num dado campo de problematização ${ }^{4}$.

A cartografia investe no acesso a um plano que agrega uma série de vetores heterogêneos atrelados à pesquisa: a pesquisadora e seus instrumentos técnicos, suas posições políticas, seu campo problemático, o grupo de pesquisa, as alianças institucionais e um conjunto de interlocuções acadêmicas, esses elementos contribuem para o traçado de um plano comum e heterogêneo. Além disso, é necessário que a pesquisadora desenvolva a construção de determinadas estratégias, que serão explicitadas posteriormente, para engajar seu campo de pesquisa. Trata-se do que é compartilhado no coletivo e o que existe de abertura comunicacional entre os sujeitos participantes das investigações, o que inclui, nesse plano, pesquisador/a e pesquisados/as, por isso a cartografia aposta na construção coletiva do conhecimento (Kastrup \& Passos, 2014).

A prática de escrita é, a partir de procedimentos que lhe são próprios, um momento crucial onde são construídas possibilidades de entradas e saídas de um texto. Inicialmente, este pode ser concebido como um mapa heterogêneo e móvel que apresenta conexões entre signos e campos de forças. Sem saber por onde começar, a escritora cartógrafa ${ }^{5}$ vê a sua pesquisa como mergulho num campo de problematizações; quando se deparou com a sua própria política de escrita foi mobilizada a descobrir algo que forçava seu pensamento, abalasse-o e o arrastasse a uma busca. Sendo necessário encontrar ferramentas e significantes para afirmar determinados modos de narrar, que apresentasse, além de efeitos e implicações, a passagem de um saber técnico para uma forma de arte.

Narrar, recontar, descrever, explicar, produzir um texto-experiência, fazer do mesmo texto matéria de expressão de um registro inevitável, do vivo e do vivido. Traduzir a experiência solicitou que a escritora cartógrafa capturasse o que havia de inédito na linguagem, o que não era dito e nem visível, num primeiro momento, mas sensorialmente perceptível. Para tal, foi necessário convidar afetos e perceptos, fazê-los mover, dar-lhes corporeidade. O que se evoca é a possibilidade de pensar por sensações e gerá-las no convite a leitura desta tese, pois entende-se que, a partir de uma erotização da experiência estética com a linguagem (Barthes, 1973), a escrita diz respeito a sucessivos momentos de êxtases com o ato da leitura. A todo momento, questionei-me se o meu processo de escrever poderia garantir o acesso e o prazer da/o leitora/or ao texto.

4 Não se trata de um ato fortuito colocar em análise toda uma teorização sobre o meu processo de escrita no início desta apresentação, pois compreendo que o doutorado é o momento que temos para nos tornarmos responsáveis por nossa própria autoria; a escrita da tese se configura, portanto, como um ponto de partida de uma jornada. Na cartografia, entende-se que quando o trabalho de pesquisa interroga o/a próprio/a pesquisador/a, há a abertura de uma zona de implicação, o que passa a exigir do/a autor/a "uma capacidade de explicitar o jogo de validação também como sujeito implicado" (Merhy, 2004, p. 6).

5 A reflexão metodológica apresentada em terceira pessoa do singular e no feminino visa marcar um determinado lugar de fala que, por vezes, é relatada na primeira pessoa do singular para situar a trajetória da pesquisa. Trata-se de uma técnica que procura demonstrar a polifonia e a mistura de vozes na possibilidade de construção de uma autoria na escrita científica. Por outro lado, é um recurso importante quando me trato como pesquisadora no feminino, pois posso colocar em xeque a linguagem neutra da ciência: o masculino como ponto de vista dominante na produção do conhecimento. 
Por isso a política da escrita enquanto poiesis ${ }^{6}$ é uma importante orientação em que se visa acesso ao plano intensivo de forças. Trata-se de um plano movente que circunscreve sentidos e perspectivas sobre a realidade e a experiência humana, gera possibilidades de transformação do mundo e põe em jogo as aporias do método. Assim, o modo de pesquisa pela cartografia é concebido como invenção da escrita de si, do outro e do mundo. É importante pontuar que determinados modos de narrar acrescentam rigor à investigação, implicam em uma formação estético-política da pesquisadora e ainda podem colocar em xeque o paradigma representacional em ciência. Neste trabalho, por exemplo, tomou-se a posição de questionar as máquinas de produção do poder sobre o gênero e a sexualidade e incomodar os modos hegemônicos de produção da subjetividade.

A concepção de autoria desenvolvida no ato de cartografar opera diferente de um método de pesquisa que se dá pela interpretação como reprodução do mesmo. Em qualquer processo de análise existe a aparição de vozes distintas, "sempre uma voz numa outra voz" (Zourabichvili, 2016, p. 20), por isso as enunciações dos sujeitos participantes, pesquisador/a e pesquisados/as, apresentam-se e organizam-se de modo plural no traçado do plano comum. Assim, pode-se notar que esta autoria se formou por meio de singularidades e posições de sujeito; só foi possível realizar a tessitura de ideias mediante sistemas variáveis de signos. Contraria-se, então, o método que toma o procedimento da interpretação como reprodução, quando o/a pesquisador/a acredita que faz coleta e análise com rigor e não observa que imprime sua voz nos "dados" ". Ele pode fazer a sua própria a dos participantes e confia, acima de tudo, na existência de uma neutralidade inabalável no seu processo de pesquisa.

Segundo Deleuze e Guattari (2000), o pensar se dá a partir de colagens, roubos, linhas de fuga. Por sua vez, Bakhtin (2010) afirma que a construção do nosso discurso se dá a partir da apropriação da palavra alheia. Para este autor, a polifonia pode ser caracterizada tanto pela heterogeneidade enunciativa, em caso de evocações de autores em obras acadêmicas, como pela forma constitutiva, onde não há menção ou citação direta, mas a autoria é apresentada de forma evidente no texto (Bahktin, 2010). De acordo com tais perspectivas e reafirmando o ponto de vista desta autora, o escrever se movimenta por heterogeneidades que habitam zonas de implicações e é situado exatamente na articulação com o que há no fora do texto. O escrever somente é possível a partir de variadas maneiras de pensar-COM alguém.

Essa incursão acerca da cartografia contextualiza a trajetória da pesquisadora segundo um

6 Poiesis é um termo etimologicamente derivado do grego que significa criar, inventar, produzir. É a raiz para o nosso conceito moderno de poesia. $\mathrm{O}$ trabalho poético conduz a um encontro do ser humano com o mundo através da arte com a escrita. Kastrup e Passos (2014), do mesmo modo, entendem que "há uma dimensão da realidade em que ela se apresenta como processo de criação, como poiesis, o que faz com que, em um mesmo movimento, conhecê-la seja participar de seu processo de construção" (p. 16).

7 Pode-se citar o exemplo do que acontece em ciências duras sob a nomenclatura de "erro de paralaxe". Trata-se de um erro que ocorre devido à influência da observação do/a pesquisador/a no seu campo de investigação. Pode acontecer em pesquisas físicas, quando durante a leitura de uma escala de graduação há um desvio óptico causado pelo ângulo de visão do/a observador/a. Por outro lado, na cartografia, não se parte da ideia de neutralidade, sempre vai existir a influência da/o pesquisadora/or no seu campo, mesmo no campo de estudo da psicologia. É importante, portanto, colocar em análise essa dimensão. 
ethos próprio de fazer pesquisa. A ideia é também localizar pontos importantes como apresentar quando surgiu o interesse pela metodologia trabalhada e ainda situar o porquê conceber uma pesquisa sobre experiências trans ${ }^{8}$ pela cartografia. Pode-se dizer que a ideia inicial do trabalho partiu de insatisfações com modelos tradicionais de produção do conhecimento e com perspectivas acríticas em psicologia do desenvolvimento. Portanto, tive a preocupação em traçar novas questões endereçadas à psicologia mediante uma saída metodológica.

O interesse pela perspectiva pós-estruturalista surgiu desde a graduação em Psicologia na Universidade de Brasília, quando comecei a participar de cursos de extensão sobre a filosofia da diferença e pude me aprofundar no assunto por meio de diversas leituras individuais. Uma delas foi o livro Mil Platôs (Deleuze \& Guattari, 2000), que é um marco para o surgimento da pesquisa cartográfica. Tais interesses têm a ver com a minha afinidade por temáticas interdisciplinares na aproximação entre a psicologia e a filosofia. Ao longo do mestrado e doutorado busquei imprimir essa influência em minhas investigações.

Gostaria também de situar o porquê ter realizado o doutorado sanduíche no Brasil, no Instituto de Psicologia da Universidade Federal do Rio de Janeiro, posso afirmar que foi por uma dimensão política. Antigamente, tinha-se a prática de ir para a Europa ou Estados Unidos, pois não havia doutorado no país, foi na década de 90 que essa realidade começou a ser possível. Hoje começamos a observar que temos oferecido, em muitos momentos, teorias e propostas metodológicas inovadoras. Minha ideia foi a de trazer a perspectiva de uma produção científica em psicologia a partir de uma problematização acerca do colonialismo cultural. Este ponto de partida não diz respeito a somente pesquisar nossos problemas de pesquisa a partir da localização de nossas perspectivas, mas a se refere a geração de novos delineamentos de pesquisa a partir de nossos próprios saberes. Essa pode ser uma estratégia utilizada para nos valorizar enquanto pensadoras/es, quando redescobrirmos nosso potencial na geração de novas tecnologias de análise. Assim, a internacionalização das trocas de conhecimentos poderia fazer sentido, quando pudermos descentralizar a produção hegemônica de políticas de saber, poder e verdade. Ou como poderíamos, nós, latino-americanos, levar nosso conhecimento produzido para os centros do poder econômico numa vertente decolonial?

8 Experiências trans é um termo guarda-chuva que apresenta as especificidades das experiências transgêneras, travestis e transexuais. No contexto deste trabalho, foi importante aproximar os conceitos de transgeneridade e de transexualidade, pois se tratam de vivências diferentes, mas próximas no que se refere aos seus questionamentos aos regimes hegemônicos de produção de subjetividades pautados pela cisnormatividade. Para a American Psychological Association (APA, 2015), "pessoas transgêneras ou as que apresentam a não-conformidade de gêneros (TGNC) são aquelas que têm a identidade de gênero não totalmente alinhada com o seu sexo atribuído ao nascimento. A existência das pessoas TGNC tem sido documentada em várias culturas e contextos históricos" (p. 832). A APA escolheu o termo TGNC, que significa pessoas trans e que apresentam a não-conformidade de gêneros, por considerar o mais inclusivo a ser adotado, até então. De maneira distinta a das pessoas transgêneras, o termo "cisgênero" é usado para se referir àqueles sujeitos cujo o sexo designado ao nascer é alinhado com a sua identidade de gênero (Serano, 2007; APA, 2015). 
O problema de pesquisa escolhido para o doutorado, portanto, foi pensado para dar uma continuidade ao meu trabalho de mestrado, que produziu campo fértil para a constituição da minha trajetória como pesquisadora. Nesse sentido, trata-se de um prolongamento de reflexões anteriores, que abarcam, inclusive, os meus contatos com a pesquisa na iniciação científica. Nesta época, o interesse de investigar os conceitos de identidade e diferença se deu no intuito pensar a produção da subjetividade entre o individual e o coletivo (Delmondez \& Pulino, 2014). Enquanto a identidade foi avaliada como posições de sujeito dentro de um arcabouço político-representacional, a diferença é o principal constructo para se referir aos processos de subjetivação da experiência de sujeito(s), no sentido em que a subjetivação traduz a experiência de diferenciação no próprio self do sujeito.

No mestrado, a trajetória se centrou na seguinte questão de pesquisa "o nosso momento presente tem inaugurado novas subjetividades", em que foi realizada uma contextualização geral do cenário contemporâneo no intuito de fazer uma leitura sobre o tempo presente e suas transformações, traçando um impacto sobre a teorização da subjetividade. Houve uma transição de escolhas de campos problemáticos entre o mestrado e o doutorado, da diversidade sexual à identidade de gênero.

No primeiro momento, a diversidade cultural era o foco de pesquisa e a questão da diversidade sexual apareceu como efeito de um analisador, a partir da abertura de um plano comum entre a pesquisadora e os/as sujeitos/as participantes. Tanto a delimitação teórica do respectivo trabalho quanto a pesquisa de campo, cujos resultados enfatizaram discursos e experiências acerca da diversidade sexual e de gêneros (Delmondez, 2013), fizeram-me pensar no fio condutor conceitual do doutorado, em que se pretendeu investigar as experiências trans a partir de narrativas.

É importante situar que, por um lado, os atuais coletivos feministas e LGBTQ ${ }^{9}$ têm promovido pautas sobre gênero, corpo e práticas sexuais e por isso têm alcançado visibilidade pública sobre a importância de suas demandas. Por outro lado, percebe-se a existência de correntes político-ideológicas, no cenário institucional brasileiro, que objetivam uma regulação unilateral dos discursos sobre gênero a partir da preservação de seus privilégios.

Neste sentido, pode-se perguntar o porquê da escolha do método da cartografia para analisar as práticas de subjetivação em experiências trans, a partir do conceito de dispositivo da transexualidade? Historicamente, modelos tradicionais de investigação tornaram padronizadas determinadas formas de se apresentar como humanos e, com isso, os resultados de pesquisas com tais sujeitos foram concebidos como regimes de verdade. Trata-se de um pensamento advindo de uma matriz colonial que generaliza casos exclusivos e não leva em conta a singularidade de cada sujeito.

A cartografia apresenta o que há de relevante no âmbito singular da experiência e considera a influência dos modos dominantes de produção do conhecimento na vida de sujeitos. Estes são

A sigla LGBTQ significa Lésbicas, gays, bissexuais, transexuais e queers. Estes/as últimos/as podem incluir também a expressão "identitária” de pessoas trans não binárias. 
vistos como máquinas de produção que se organizam a partir de determinadas racionalidades, a saber: o binarismo de gênero, o falocentrismo, a cis ${ }^{10}$ e heteronormatividade. Portanto, pode-se abordar, conforme este método, os modos hegemônicos de produção de subjetividade e analisar como sistemas de saber-poder ou biopolíticas podem afetar "outras vidas". Interessa conhecer também quais são as estratégias usadas para a formação de hegemonias machistas, homofóbicas ou transfóbicas e entender como os preconceitos surgem e ainda são reforçados. Enquanto o modelo standard não traz visibilidade à produção de conhecimento em si, a cartografia visa mapeá-la ao apresentar as racionalidades dos regimes dominantes.

$\mathrm{O}$ trabalho evoca uma crítica que diz respeito à escassez de estudos sobre gênero e sexualidade no âmbito da psicologia do desenvolvimento (Burman, 2008; 2010; 2011). O que denota uma concepção tradicional de desenvolvimento como progresso inserida dentro do projeto moderno enquanto paradigma de objetividade e neutralidade (Castro, 1992; Mattos, 2011). O não reconhecimento e a consequente não representação de determinados sujeitos no registro da ciência psicológica conduz a um enquadramento seletivo de opressão e subalternidade, segundo as normas conduzidas pela colonialidade do poder (Quijano, 2002; Alves \& Delmondez, 2015). Ao colocar um tópico de estudo em análise é possível desdobrar as racionalidades que o subjazem e colocar em questão o que antes era assumido como dado ou óbvio. Por sua vez, a desconstrução de discursos hegemônicos traz o diagnóstico de verdades que foram historicamente legitimadas, sendo viável identificar pesquisas que privilegiaram determinados conhecimentos em detrimento de outros.

A proposta é apresentar um modo particular de promover a crítica ao tomar a análise do desenvolvimento psicológico como campo problemático. Nesse sentido, esta tese tem o compromisso de ensaiar uma perspectiva diferenciada e com isso traz interrogações à psicologia a partir do seguinte eixo: a política de pesquisa da cartografia é uma entrada que poderia permitir a revisão dos conceitos de "desenvolvimento" e de "transexualidade". Ou seja, trata-se de uma cartografia em que o propósito é pesquisar as experiências trans como categorias de subjetivação para desobjetivar e desindividualizar sujeitos e, consequentemente, despatologizar as categorias de gênero e de sexo. Assim, passam a ser lidas como produções de si e modelos emergentes de diversidade, pois as vivências trans, hoje, têm se articulado mediante novas possibilidades de reconhecimento social e de cidadania.

É possível dizer que essa experiência tem emergido na história a partir do momento em que sua identidade tem sido posta como "problema ${ }^{11}$ ". A possibilidade da pessoa trans narrar a si pode

10 O termo "cis", ou correlatos como cisgeneridade, cisnormatividade ou cishegemônicas (último termo utilizado por mim), "diz respeito a um sistema cultural e ideológico que nega, difama, ou patologiza as identidades de gênero que são (auto)identificadas com base no não-alinhamento de gênero designado ao nascer". Por sua vez, "a ideologia da cisgeneridade endorsa e perpetua a crença de que as identidades e expressões cisgêneras são as melhores e agregam mais valores que as expressões e as identidades trans" (Lennon \& Mistler, 2014, p. 63). De outro modo, as práticas de si em experiências trans têm resultado em modos singulares de se comportar, numa outra expressão pessoal e em uma nova construção coletiva.

11 Segundo o dicionário de sinônimos Houassis, a palavra "problema" é adequada nesse texto, pois denota o 
ser vista como um ato de resistência, consistindo num processo de criação ativa do sujeito ao poder transformar a sua situação de vulnerabilidade e tornar a sua vivência comunicável. Assim, o sujeito pode se expressar e compartilhar aquilo que é na relação com o outro, quando se torna narrador de sua própria experiência. Subjetividades trans, como subjetivações políticas, podem criar seu próprio discurso como uma estratégia de empoderamento de si mesmos e de resistência às produções hegemônicas.

Os meus contatos iniciais com sujeitos trans se deram em atendimentos como psicóloga e em grupos de discussão em movimentos sociais LGBT. Houve a possibilidade de habitar um território (Alvarez \& Passos, 2009) para um aprendizado do processo de pesquisa, inclusive para se construir uma teorização através da prática em psicologia. Nessa cartografia foi importante, então, delimitar um território existencial, implicando-se nele para realizar um saber-COM. Assim, muito do que foi pensado partiu do contato pessoal da pesquisadora com as experiências trans. $\mathrm{O}$ campo da investigação, que se constitui nesse território existencial, redirecionou algumas perguntas: como o gênero participa dos processos de constituição da subjetividade? Ou ainda, como pensar o "desenvolvimento" a partir das práticas de produção da subjetividade na perspectiva da filosofia da diferença?

Nesse sentido, o trabalho introduz a temática da cisnormatividade e das experiências trans no contexto da psicologia do desenvolvimento, defendendo-se que em vez de se buscar uma gênese dos eventos psicológicos para compreender o que levou uma pessoa a se definir como trans, a constituição de gênero se dá a partir de práticas de produção da subjetividade, sendo que o gênero se constitui a partir de processos de autorreflexividade e de autorregulação psíquica ao longo da experiência humana, assim, é processual, dialógico e não demarcado/definido a priori.

Entende-se, portanto, que durante a pesquisa, o nomear a transgeneridade ou a transexualidade, e esta, por sua vez, como dispositivo, só fez sentido devido à hegemonia da cisnormatividade, pois se não houvesse a norma cis não poderia ser nomeável a experiência de "desvio". Nesse sentido, o gênero faz parte de ideais regulatórios discursivos e não discursivos que se materializam no corpo, nas práticas sexuais e no processo de apresentação do eu para si e para o outro. É em espaços de desenvolvimento mútuo mediante modos de objetivação/subjetivação que os sujeitos são posicionados numa determinada relação de verdade e de poder, por isso existem aquelas/es que ousam rebelar-se dessa relação emanada das normas cishegemônicas.

Trata-se de observar como as pessoas trans constroem suas práticas de subjetivação em situações concretas. Neste contexto, interessa salientar como as práticas de subjetivação se constroem pela transgressão. O enfoque realizado é sobre a produção de si por meio do gênero,

seguinte campo semântico: "1) problema como assunto, ponto, questão, tema. 2) como dificuldade, transtorno, vicissitude; 3) distúrbio, disfunção, doença; 4) dilema, impasse; 5) enigma, incógnita". (Houaiss, 2012, p. 581). Tal campo semântico traduz as inúmeras possibilidades de significação postas em disputa acerca das experiências trans. 
buscando pensar como o/a sujeito/a trans se relaciona consigo (com sua própria história, com seu corpo e sua "identidade"), autorregula-se e produz a si mesmo no contexto das relações humanas. Durante a pesquisa, recorreu-se às narrativas de pessoas trans que trouxeram indicadores sobre o ato de recorrer a determinadas memórias para justificar a sua transgeneridade ou a sua transexualidade. Neste trabalho, a concepção de memória diz respeito à produção de performances discursivas, que podem criar efeitos na conexão do sujeito com a sua experiência presente e motivar a emergência de novas interações socais.

Nesse sentido, pretende-se observar as dinâmicas envolvidas na subjetivação humana a partir de alguns eixos conceituais escolhidos: a de práticas de subjetivação em Foucault (2006a; 2006b; Candiotto, 2008; Pelbart, 2013, Rose, 2011), de memória e subjetividade pensada por Deleuze (1988/2006; 2012; Pelbart, 2007; Hur, 2009; 2013a; 2013c) e a de gênero e subjetivação por J. Butler (1997; 2001; 2013a; 2013b; Salih, 2012).

Objetiva-se neste texto superar a utilização do conceito de identidade de gênero no sentido de reificação ou ainda a representação do sujeito psicológico idêntico a si mesmo ao longo do seu desenvolvimento. Tal compreensão serviu para subsidiar a ideia de "Transexualismo", "Transtorno de Identidade de Gênero" ou "Disforia de gênero" que são categorias patologizantes e constam nos manuais internacionais de diagnósticos, a saber: o CID 10, DSM IV e DSM V ${ }^{12}$. No entanto, a concepção de identidade de gênero é um importante marcador de nossa (auto)apresentação como mulheres, homens e, acima de tudo, humanos no mundo. Ou talvez, seja melhor pontuar que as categorias de "homens", "mulheres", "feminino" e "masculino" não são mais suficientes para representar as inúmeras variações de identidades de gênero existentes, pois tem havido processos de desidentificação de gênero em relação ao sistema binário.

Percebe-se, portanto, que o problema é quando a identidade transforma o que é processual e múltiplo em algo estático e essencializado, por isso é importante ressaltar que, para Butler, não é necessário utilizar nenhum marcador de identidade para se almejar uma participação política e lutar por direitos humanos.

Nas democracias, os posicionamentos identitários constituem as posições de sujeito e a política passa a existir mediante dispositivos de subjetivação contingentes à realidade social. A ideia de pesquisar os coletivos trans visa saber como eles têm participado da produção de novas formas de sociabilidade, por meio de políticas de amizade, em práticas de cuidado de si mesmos. Os sujeitos representados pelos atuais movimentos sociais são atravessados por desigualdades de classe, gênero, sexualidade, raça, também de modo interseccional. No caso da transexualidade, há a necessidade da assistência pelo Estado de demandas jurídicas e médicas pautadas por diferentes modalidades de representação política e simbólica. Por outro lado, entende-se que os processos de reconhecimento

12 Código Internacional de Doenças $10^{\mathrm{a}}$ versão, Manual Diagnóstico e Estatístico de Transtornos Mentais, $4^{\mathrm{a}}$ e $5^{\mathrm{a}}$ versões, respectivamente. 
na atualidade precisam contemplar sujeitos políticos e modos de subjetivação.

A presente tese está dividida em dois momentos teórico-conceituais. No primeiro, apresentar-se-á as dinâmicas dos processos de subjetivação segundo M. Foucault, G. Deleuze e J. Butler. No segundo, será realizado percurso sobre a produção de novas subjetividades no contexto contemporâneo e sobre a Psicologia como um saber também constituinte do dispositivo da transexualidade.

Em seguida, será apresentada a seção oficina da pesquisa com base na delimitação dos seguintes dispositivos: 1) diário de campo da pesquisadora; 2) entrevistas narrativas e episódicas com seis pessoas trans (binárias e não-binárias). Por fim, a análise dos resultados foi separada em dois momentos: análise de implicações e avaliação de efeitos e cartografia dos processos de subjetivação. Nesse sentido, o desenvolvimento da tese foi pautado por uma pesquisa com base nos seguintes objetivos:

\section{$\rightarrow$ Objetivo geral:}

Analisar como se constituem as práticas de subjetivação em experiência trans para tecer um diagnóstico contemporâneo dos regimes de verdade presentes no dispositivo da transexualidade.

\section{$\rightarrow$ Objetivos específicos:}

- Identificar como são construídos os marcadores, em narrativas autobiográficas, para justificar a transgeneridade ou a transexualidade a partir de um olhar centrado numa perspectiva de desenvolvimento em psicologia;

- Explicar pelas narrativas de pessoas trans como se desenvolvem os processos de autorreflexividade e autorregulação psíquica;

- Cartografar a produção de novas subjetividades na contemporaneidade segundo a análise de práticas que se efetuam pela transgressão às hegemonias. 


\section{CARTOGRAFIA DOS PROCESSOS DE SUBJETIVAÇÃO}

Nessa seção será construído o referencial teórico-metodológico no intuito de orientar a condução dos processos desta pesquisa. A introdução como uma chave de leitura desta cartografia forneceu as pistas para que a/o leitora/or pudesse saber como o texto seria operado. Partindo da pergunta sobre o que é cartografar, produz-se um percurso inventivo e árduo de se realizar, visto que se trata de um procedimento ainda novo de construção científica, ainda mais no âmbito da psicologia do desenvolvimento.

A proposta mostra-se relevante devido à característica processual dos objetos de estudo dessa área de conhecimento, sendo que, em geral, são trabalhados os seguintes temas: a aprendizagem, a personalidade, os ciclos vitais humanos, entre outros. Do mesmo modo, o interesse neste trabalho é o de discutir outros aspectos como a subjetivação humana, o tempo da experiência e a constituição de gênero em experiências trans, a partir da perspectiva pós-estruturalista de M. Foucault, G. Deleuze e J. Butler.

Entende-se que a proposta da cartografia é a de pesquisar o que está em processo ou o inacabado de um como: "investiga-se como, produz-se com" (Costa, Angeli \& Fonseca, 2012, p. 46). Muda-se, então, o foco da investigação da pergunta 'por quê' para 'como', pois, assim, é possível traçar uma compreensão do modus operandi de um processo psicológico. É uma perspectiva pautada por um paradigma científico estético-político (Guattari, 1990), que visa ultrapassar modos de produção de conhecimento concebidos pela tradição moderna de ciência. "Pesquisar com a cartografia é encontrar-se com reentrâncias fugidias de dimensões mínimas que abrem problemáticas ilimitadas, sem espaço para binarismos advindos da partição abstrata do mundo em categorias estanques" (Costa, Angeli \& Fonseca, 2012, p. 46). Por exemplo, no âmbito deste trabalho, em vez de se querer traçar as verdadeiras etiologias da transgeneridade e da transexualidade e descrevê-las, busca-se analisar como o dispositivo da transexualidade se efetua também na vida de pessoas trans.

A cartografia surgiu dos trabalhos teóricos de Deleuze/Guattari (2011), principalmente em Mil Platôs, e tem sido um método relevante de produção de conhecimento em psicologia. Como um modo de pesquisa escolhido possibilitará traçar um percurso para a construção da proposta que se pretende investigar. Encontra-se na abertura do trabalho, pois se objetiva construir um novo referencial metodológico para a psicologia do desenvolvimento humano, junto à produção teórica a ser realizada, que dá sentido ao caminho da investigação. Para tanto, a principal preocupação é seguir diretrizes coerentes ao longo da tese para a validação do procedimento escolhido.

Passos e Kastrup (2013), no intuito de qualificar a prática de pesquisa, desenvolvem as seguintes diretrizes de validação: o acesso à experiência, a consistência cartográfica e a produção de efeitos. Estas precisam ser avaliadas em três níveis: a autoavaliação produzida pela/o própria/o pesquisadora/or, a das/os participantes e a avaliação por pares. Todos os níveis devem ser observados em todas as três diretrizes para compor uma validação distribuída e integrada. 
Por exemplo, no que se refere ao acesso à experiência, as/os autoras/es definem questões orientadoras: a/o pesquisadora/or fez parte e ainda avaliou a sua experiência no processo de pesquisa? Os/as participantes imergiram na experiência no intuito de avaliá-la? O texto da investigação possibilita que as/os avaliadoras/es acessem a experiência da pesquisa realizada? Por sua vez, o conceito de consistência orienta o processo de validação pois diz respeito aos agenciamentos realizados durante a pesquisa, como "a relação entre a perspectiva teórico-conceitual, a constituição dos dispositivos, a orientação da produção dos dados e os resultados e efeitos observados" (Passos \& Kastrup, 2013, p. 405). Há consistência quando é realizado o maior número de conexões entre cada um desses elementos. A validação da pesquisa cartográfica precisa avaliar os efeitos produzidos, nos três níveis, dos processos disparados pelos dispositivos e compreender se e como foram geradas transformações durante a intervenção no campo de problematização.

O caminho metodológico a ser seguido afirma que a prática de pesquisa advém de um saber da experiência: "do saber na experiência à experiência no saber (...) o que tem primado é o plano da experiência enquanto intervenção, em que estão sempre encarnadas as ferramentas conceituais e os operadores analíticos" (Passos \& Barros, 2009, p. 18). Para a cartografia toda pesquisa implica uma intervenção na realidade e, dessa forma, há uma dependência intrínseca entre o conhecimento e a prática e entre pesquisar e intervir. Em outras palavras, a experiência é compreendida como um saber-fazer, um saber que surge do fazer e, nesse sentido, trata-se de transformar para conhecer e não de conhecer para transformar a realidade. Para Foucault (2012b), a teoria é sempre local e nãototalizadora, sendo indissociável da prática. Nesse sentido, não se trata de uma representação ou aplicação da teoria, pois se constitui em si mesmo uma forma de se fazer a prática.

$\mathrm{Na}$ cartografia, os dispositivos fazem a pesquisa operar em diferentes níveis ou relevos. Ao mesmo tempo em que cada dispositivo faz emergir regimes de saber-poder e de subjetivação, pode ser concebido como um pré-texto ou um disparador inicial (cada um dos procedimentos da pesquisa). Nesse sentido, traz à tona elementos antes dispostos de maneira difusa para, depois, possibilitar o desenredo de nós em possíveis linhas de análise. Os dispositivos podem ainda mobilizar a transformação de mecanismos ou de práticas ao promover operações nas engrenagens do socius, ou seja, tem uma função estratégica concreta na realidade analisada pelo seu caráter de positividade ${ }^{13}$.

Para Deleuze (2003), são vistos como máquinas que possibilitam ver e falar, mediante

13 Agamben pontua que a noção de "positividade" dá a Hegel uma conotação histórica para a sua filosofia, pelas relações estabelecidas entre as regras, os ritos, as instituições e como estas são impostas aos sujeitos pelo poder que lhes é exterior, e pela sua interiorização em seus sistemas de valores e em seus sentimentos. Nesse ínterim, Foucault toma emprestado o termo "positividade" para depois classificá-lo como "dispositivo" e articulá-lo a seguinte proposição: "a relação entre os indivíduos como seres viventes e o elemento histórico, entendendo com este termo o conjunto das instituições, dos processos de subjetivação e das regras em que se concretizam as relações de poder. O objetivo último de Foucault não é, porém, como em Hegel, aquele de reconciliar os dois elementos. E nem mesmo o de enfatizar o conflito entre estes. Trata-se, para ele, antes de investigar os modos concretos em que as positividades (ou os dispositivos) atuam nas relações, nos mecanismos e nos 'jogos' de poder" (Agamben, 2005, p. 10). 
campos de visibilidade e dizibilidade. Neles aparecem relações forjadas por discursos e suas estratégias de poder-saber. No entanto, para Foucault, o dispositivo se apresenta como um conjunto heterogêneo composto por ditos e não ditos de discursos, instituições, decisões regulamentares, leis, enunciados científicos, proposições epistemológicas, enfim, configura-se em formato de rede que se estabelece entre esses elementos. Tanto 'o dito e o não dito' quanto 'o visível e o não-visível' constituem os elementos do dispositivo.

Agamben (2005), leitor de Foucault, por sua vez, entende que o conceito de dispositivo traz em questão o modo como algo tem de "capturar, orientar, determinar, interceptar, modelar, controlar, e assegurar os gestos, as condutas, as opiniões e os discursos dos seres viventes" (p.13). Assim, entende que os objetos tecnológicos, a escritura ou a linguagem ${ }^{14}$ mesma levou e ainda nos leva a consequências de nos deixar capturar de determinada forma e condições. Ou seja, é possível dizer que todo dispositivo tem como efeito atuar em sujeitos e por isso implica num processo de subjetivação. Quando colocamos em análise as suas positividades, o que lhes constituem são seus efeitos discursivos e não-discursivos, passamos a intervir sobre tais dispositivos.

No contexto desta pesquisa, o dispositivo é visto como uma ferramenta para a composição do problema de pesquisa, ele auxilia a observar as racionalidades técnicas e institucionais do respectivo problema e produz visibilidades. Em síntese, é pelo dispositivo que se constrói a pesquisa, pois, a partir de sua operação, pode-se enunciar outros dispositivos e linhas de natureza heterogêneas (visibilidade, enunciação, força e subjetivação) ${ }^{15}$ que os compõe. Além disso, quando se põe em análise os elementos dos dispositivos, alguns analisadores emergem como um de seus efeitos num movimento de produção de sentidos.

Trata-se de uma proposta concebida pela Análise Institucional Francesa (Lourau, 1993; Guattari, 2008). Consoante tal perspectiva, os analisadores são elementos que podem ser observados em pontos de discussão importantes, são ainda vistos como acontecimentos singulares e podem trazer o registro de novos regimes de visibilidade. Nesse sentido, os analisadores são acontecimentos dispostos em formações discursivas e não discursivas e possibilitam fazer com que uma dimensão analítica opere a partir de suas linhas de força. De acordo com o paradigma não-representacional em ciência, pode-se dizer que propicia um excedente de visão devido à geração de sentidos em várias dimensões da realidade.

Esse excedente de visão envolve a responsabilidade na constituição de sujeitos e de mundos com os quais interagimos no processo de pesquisa em ciências humanas (Bakhtin, 2010; 2011). Esse

14 Segundo Agamben, cada um desses exemplos pode ser citado como um dispositivo: objetos tecnológicos (celulares, computadores, entre outros), a escrita ou a linguagem, pois tem atuado de diferentes formas nos processos humanos de subjetivação.

15 Deleuze (2003), em $O$ que é um dispositivo?, ainda acrescenta as linhas de estratificação ou de sedimentação, linhas de atualização ou de criatividade. É importante pontuar que, independente da natureza das linhas, o dispositivo opera por decomposição dos elementos analisados em vários e diferentes eixos. 
ethos também diz respeito ao desafio de apresentar os analisadores no intuito de problematizar os seus efeitos discursivos e não discursivos e desnaturalizar racionalidades antes assumidas como dadas e tratadas de forma invisibilizadas. No ato cartográfico, toda análise gera uma zona de implicações que é coextensiva ao modo como a/o pesquisadora/or situa o seu problema de investigação; por isso, nos analisadores, surgem coordenadas e elementos processuais de produção de novos sentidos relacionado ao dispositivo.

Com a proposta de argumentar sobre o conceito dispositivo da transexualidade, coloca-se em evidência um modelo standard de psicologia que evoca uma forma particular de entender "as identidades de gênero". Ou seja, diz sobre concepções historicamente eleitas pela moderna ciência psicológica para traçar um modo determinado de pensar o desenvolvimento ao longo do curso de vida. No contexto deste trabalho, portanto, trata-se de trazer novos regimes de luminosidade no intuito de demonstrar como correntes da psicologia podem ser hegemônicas, pois, a partir delas, organiza-se uma determinada normatividade.

Além disso, o dispositivo da transexualidade diz sobre as formações discursivas das racionalidades hegemônicas em que se produz a cisgeneridade (Serano, 2007, 2013; Stryker, 2008; Ansara \& Hegarty, 2012; Finn Enke, 2013; Aultman, 2014; Lennon \& Mistler, 2014; Cidade, 2016) como norma e regime de governamentalidade ${ }^{16}$, que "cria um sistema inerente e associado ao poder e ao privilégio" (Lennon \& Mistler, 2014, p. 63).

A sugestão é colocar um debate sobre a maneira como tanto as hegemonias cis quanto o binarismo de gênero constroem subjetivações, pois se trata de normas que subjetivam a todos nós. São modos de funcionamento que se operam invisíveis e se organizam a partir de determinadas práticas de governamentalidade ${ }^{17}$. Logo, a cisgeneridade enquanto um regime discursivo de

16 Governamentalidade é uma concepção trabalhada por Foucault para situar, do ponto de vista genealógico, como se processaram os eventos históricos que originaram a passagem da dimensão política da soberania real para o governo estatal na modernidade. Nesse ínterim, Foucault descreve três formas diferentes de governamentalidade que operam de modo concomitante e integrada. Trata-se do conjunto constituído por instituições, procedimentos, estratégias, análises que possibilitam o exercício de uma forma bem específica e complexa de poder. A família assume o papel de ser o catalisador que transformará as táticas de governo em ações concretas no intuito de obter controle sobre a população. Através de um modo de funcionamento cada vez mais capilar, é necessário que haja práticas de governo das pessoas sobre si mesmas, assim, observa-se a diminuição e despersonalização da figura de autoridade do governante. Em um arranjo sincrônico, surgem as ciências de administração do governo que assumem a função de gestão da população: a estatística, a economia e as ciências humanas em geral. Nesse sentido, produz-se a relação de sujeito-objeto ao qual o governo se dispõe para avaliar o direito à educação, ao trabalho, à saúde, e os profissionais, com seus conhecimentos, atuam no sentido de exercer uma prática de governamentalidade para, por exemplo, recuperar ou reintegrar os indivíduos. Há uma função circular entre os governos moral, econômico e político, pois o primeiro está relacionado ao governo de si mesmo, o segundo diz respeito à família e o terceiro ao Estado. Essas três formas de governo se organizam a partir de conexões entre si e por isso há várias modalidades de governo no interior do socius, que não é controlado diretamente pelo poder político de um país como se dava na soberania. A última forma de governamentalidade resultou-se de vários processos pelo qual o Estado de Justiça da Idade Média tornou-se governamentalizado (Foucault, 2012a).

17 Esse debate é demonstrado a partir da própria invisibilidade da discussão cis. É como se existisse a pessoa trans de um lado e o gênero normal e natural de outro; o conceito de "cisgênero" é uma construção discursiva para dar visibilidade a essa hegemonia e para questionar o entendimento de que tanto gênero quanto sexo são 
regulação social objetiva fabricar determinados modos de subjetivação, por isso atua sobre os sujeitos em suas práticas de si mais singulares. Tais práticas podem ser notadas na forma como a pessoa se entende no mundo ou tece explicações de si e do outro.

O que é cisnormativo se opera de acordo com uma racionalidade num jogo entre as concepções de identidade e diferença, em um processo social e cultural de construção de categorias inteligíveis (Delmondez \& Pulino, 2014). Trata-se de uma política de produção da identidade e da diferença organizada por meio de relações macro e capilares de poder (Deleuze \& Guattari, 1997a; Foucault, 2012), é possível situar tais afirmações colocando em evidência um exemplo emblemático: um grupo social - os brancos - é eleito como dominante, torna-se historicamente uma categoria invisível e as diferentes variações sociais são excluídas e demarcadas (Silva, 2007; Woodward, 2007; Hall, 2007).

Do mesmo modo, pode-se notar que há uma organização binária entre o posicionamento e a classificação da identidade e da diferença: masculino/feminino, branco/negro, heterossexual/homossexual ou, ainda, cisgeneridade/transgeneridade (cissexual/transexual). É preciso levar em consideração a existência de uma armadilha em entender esses termos como antagônicos em posições extremas, "questionar a identidade e a diferença como relações de poder significa problematizar os binarismos em torno dos quais elas se organizam" (Silva, 2007, p. 88). A categoria "cisgênero" não pode ser usada para separar pessoas ou grupos, pois as lógicas binárias tendem a manter presente jogos de poder desiguais, de outro modo, é importante utilizá-la para trazer regimes de visibilidade sobre as práticas de subjetivação dos sujeitos.

O dispositivo produz mundos e também se engendra sobre os corpos, o seu efeito, por sua vez, é fazer com que a experiência trans seja objeto de estudo da ciência. Portanto, não há "a transexualidade" e "uma normalidade" como registros separados e antagônicos. A categoria trans só se tornou inteligível porque foram criados entendimentos de que existe um ser humano fora do padrão e o sujeito “cis", por sua vez, tem sido invisibilizado na história desde então. Logo, o conceito cisgênero (Serano, 2007; Stryker, 2008; Finn Enke, 2013; APA, 2015) foi criado para dar inteligibilidade a essa máquina de produção.

Fez-se operar, socialmente, um discurso de que há "os normais" e "os/as trans". Neste contexto, nomear as experiências trans só tem sentido devido à hegemonia da cisnormatividade, senão houvesse essa norma não seria nomeável a experiência de desvio. Torna-se necessário, portanto, colocar em análise o discurso da normalidade a partir dos processos de subjetivação desenvolvidos e construídos através de práticas normativas, segundo um ideal regulatório, pois o que está em jogo é a hegemonia, ou seja, a construção de uma hegemonia cisnormativa assim como a de uma hetero. $\mathrm{O}$ que ambas criam como efeitos são racionalidades para se interpretar uma experiência

entendidos como fabricações naturais. É tão hegemônico que tem sido um conceito marginal no âmbito dos estudos sobre a transexualidade e no senso comum. 
como normal e a outra como desvio.

Apresentar um novo regime de luminosidade passa pelo entendimento não de um sujeito auto-identitário e privatista, de outro modo, vislumbra-se pensar por meio de planos de fabricação da subjetividade. Nesse sentido, a ideia é sair da esfera individual da motivação e da auto-estima para compor um conhecimento sobre como o desenvolvimento psicológico pode ser visualizado de acordo com uma perspectiva de produção, pois a categoria subjetivação não somente desobjetiva sujeitos, mas também os desindividualiza.

Importante salientar que o enfoque é sobre como as práticas de subjetivação se constroem pela transgressão a uma hegemonia cisnormativa. Podemos nomeá-las como práticas de si, que se realizam pelo desenvolvimento de estratégias para não sermos tão governadas/os assim. O conceito dispositivo da transexualidade atrelado às práticas de subjetivação faz operar uma transgressão da ideia de gênero entendido como sexo natural ou biológico, daí avaliar como esses conceitos foram entendidos historicamente e como isto se reflete nas práticas atuais de governamentalidade. Atualmente, a visibilidade da pessoa trans é importante, dentre vários motivos, para nos fazer lembrar que todas as subjetividades são construídas, esse é um indicador discursivo gerado pela análise do dispositivo da transexualidade.

Após essa incursão sobre como o campo problemático foi tecido, tem-se em mente a importância de seguir um rigor durante a prática da cartografia sem perder de vista o seu caráter inventivo. Trata-se de aplicá-lo mediante a descrição das etapas da pesquisa a partir do desenvolvimento de uma determinada política de escrita. Assim, pode ser possível observar as conexões entre os dispositivos, a coerência na forma como é realizada a costura dos conceitos e no modo como os campos de forças tornam visíveis as racionalidades.

Logo, quando se pratica a cartografia não há a possibilidade de coletar dados, seguindo a lógica representacional, pois se entende que o conhecimento é produzido no encontro com a realidade: "a pesquisa se faz como um mergulho na experiência no qual emerge o si e o mundo (...) o entrevistador colhe e acolhe a experiência" (Passos \& Kastrup, 2013, p. 386). Nesse sentido, pela possibilidade de promover intervenção sobre os acontecimentos da realidade ou ainda sobre processos de subjetivação, é necessário redesenhar o sentido comumente concedido ao procedimento "coleta de dados".

De outra forma, define-se como "colheita de dados" para reafirmar o ponto de vista da cartógrafa de que há a produção e não a representação do mundo a ser investigado. $\mathrm{O}$ ato da pesquisa é mais o de colher ou ainda acolher as informações para lhes dar sentido, em que podem ser mobilizados afetos, pois há mais um processo de encontro com o que se quer conhecer (entre a/o pesquisadora/or e os/as participantes) numa agência entre vida e pesquisa. A partir daí, pode-se operar um desenho do campo de problematização, delineando-se diagramas inventivos num plano gráfico-textual, a fim de traçar um novo design metodológico à Psicologia.

Em Mil Platôs, Deleuze e Guattari (2011) desenvolvem um sistema de conceitos em que o 
diagrama aparece como um recurso para analisar os agenciamentos e a processualidade de signos. Para os autores, há regimes de signos que dizem respeito a qualquer formalização de uma expressão linguística. Estes constituem uma determinada semiótica. Por sua vez, a semiótica dos diagramas funciona segundo as variáveis de tempo, espaço e movimento. Nesse sentido, o diagrama é um desenho linear e figurativo realizado para propósitos científicos, sendo que sua função não é representar objetos, mas sugerir e interpretar mundos possíveis.

Na semiótica de Pierce (1999), o processo representacional diz respeito tanto ao pensamento quanto à representação de um objeto externo e se dá a partir da tríade entre signo-objetointerpretante. Peirce (1999) classifica os signos, de acordo com a interação signo-objeto, em ícone, índice e símbolo. Estes representam desde a qualidade pura de um objeto ao processo de convencionalização ou aquisição de conhecimento.

Por sua vez, o diagrama é um sistema de representação móvel, pois, ao derivar de sua condição triádica - da relação com os três níveis semióticos propostos por Peirce -, possui um caráter múltiplo como signo diagramático. O que condiz com a sua forma e constituição, por um aspecto icônico presente na semelhança entre suas partes e entre as do objeto, tornando-se meio de criação. Esta é a condição a partir da qual associam-se outras duas: uma indicial, contemplada nas partes do objeto que nele foram agregadas, o que lhe confere a característica de ser indicador deste objeto; outra simbólica, que diz respeito as regras segundo as quais foi constituído, outorgando-lhe um caráter mediacional ou comunicativo (Pierce, 1999; Sperling, 2003).

Para a semiótica peirceana, há no diagrama o entrelaçamento entre o processo de representação e criação, visto que, por meio do desenho e de sua observação, novas relações entre partes que antes pareciam não ter conexão podem ser criadas. Existe um caráter semiótico eminentemente metaprocessual do diagrama, pois, ao ser um ícone, representa por identificação e promove um mapeamento, ou seja, uma representação do processo que investiga e se torna uma criação (Sperling, 2003).

A formulação do conceito de diagrama por Deleuze/Guattari (2011), se orienta pela qualidade do signo icônico e o corrompe: "é nesse sentido que os diagramas devem ser distinguidos dos índices, que são signos territoriais, mas igualmente dos ícones, que são de reterritorialização, e dos símbolos, que são de desterritoriaização relativa ou negativa" (Deleuze/Guattari, 2011, p. 105). Para Deleuze/Guattari (2011), o diagrama é constituído por uma máquina abstrata que produz conceitos, tornando-se uma promessa do fato e não o fato em si mesmo. Por essa ótica, o diagrama é como um devir e não captura a essência do objeto, mas se constitui como sua possibilidade (Sperling, 2003; Deleuze, 2007).

O diagrama é instável ou fluído e, como uma máquina abstrata, conecta matérias e funções para constituir novos conceitos (Deleuze/Guattari, 1997; 2011). Esta máquina indica aspectos que podem ser compartilhados por conta de suas conexões entre discursos e materialidades (Rose, 2011). Os diagramas surgem, então, para subverter a noção de que se faz pesquisa a partir da coleta de 
dados. Ele não funciona para representar um mundo pré-existente, mas para produzir uma análise e interpretação provisória sobre fatos e objetos de pesquisa. Passa a ser mais uma possibilidade de produção do que de reprodução. Trata-se de um desenho gráfico que descreve, ou ainda explica, mais do que representa relações estratégicas entre objetos ou pessoas. Assim, são construções inéditas sobre um determinado campo problemático investigado, tal como aparece na obra de Magritte "Isso não é um cachimbo", abaixo:

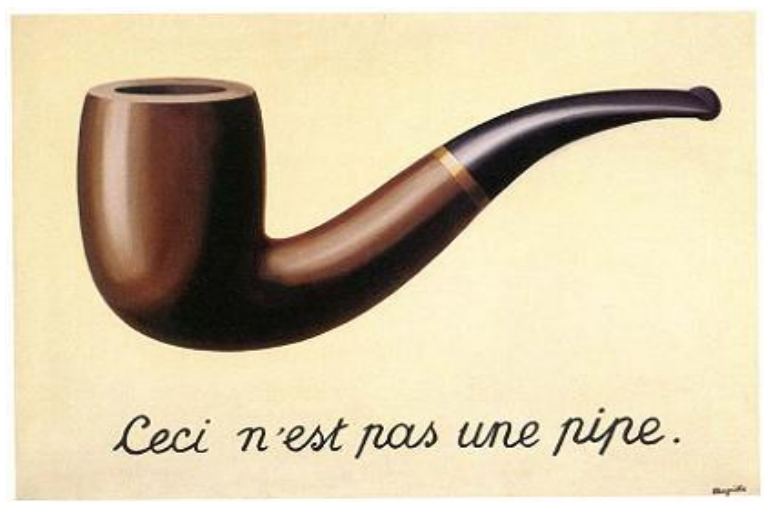

Diagrama 1. Isso não é um cachimbo por Magritte

Para essa pesquisa o diagrama será uma ferramenta teórico-metodológica essencial, visto que será um recurso para a organização das informações construídas em campo e das análises. Além de que, por meio do seu caráter explicativo, poderá permitir a tradução dos processos de subjetivação, das dinâmicas da constituição de gênero, da (co)existência entre o tempo da experiência e o da narrativa, que são outros conceitos a serem trabalhados no âmbito da psicologia do desenvolvimento. Visa-se, por meio desse procedimento, conduzir um texto preocupado em não produzir análises com base em generalizações. $\mathrm{O}$ que ocorre entre o singular e o coletivo tem um peso importante para a psicologia e, de alguma forma, diz sobre a experiência de subjetivação humana.

Importante considerar o que caberia a uma psicóloga que realiza esse modo de fazer pesquisa. A teoria se configurou como uma cartografia em que a prática da cartógrafa é um elemento chave da pesquisa, pois realiza uma análise da subjetividade no campo social. Essa se conduz junto com as paisagens cuja constituição e desenvolvimento ele/a mesmo segue. A cartógrafa definiu primeiro os seus critérios estético-políticos que, depois de efetuados segundo um ethos próprio de fazer pesquisa, partiu para sua expedição em campo. Nesse sentido, serei uma designer de conceitos no intuito de cartografar as práticas de si como estratégias de transgressão às hegemonias, em especial, as cisheteronormativas, no espaço-tempo contemporâneo.

Existem teses brasileiras que se aproximam da análise dos processos de subjetivação na transexualidade numa perspectiva sociológica (Oliveira, 2013) e psicanalítica (Lionço, 2006), mas que a tratam a partir de diferentes domínios teóricos. Foram trabalhadas, respectivamente, os discursos psicológicos de atendimento clínico a transexuais e uma teorização sobre a transexualidade a partir da tensionalidade somato-psíquica. 
Por sua vez, neste trabalho, é conduzida uma pesquisa sobre como as experiências trans podem ser entendidas a partir de suas práticas de subjetivação a fim de se pôr em xeque perspectivas que enquadram vidas humanas dentro de um viés cisheteronormativo e psicopatológico. Por consequência, coloca-se em cena um sentido estético-político do despatologizar. Na tessitura de um diagnóstico contemporâneo dos regimes de saber-poder presentes no dispositivo da transexualidade notei duas principais correntes. Uma como índice de governamentalidade derivada de estratégias e de discursos normalizadores e outra que se efetua como processo de subjetivação.

Portanto, pretende-se defender sobre como as subjetividades trans têm sido produzidas a partir de resistências ao dispositivo da transexualidade, enquanto um paradigma científicoinstitucional (Bento, 2006; Lima, 2010), em movimentos sociais de visibilidade e dignidade trans, numa agência entre sujeitos, coletivos, discursos e instituições, com base em políticas da amizade. Faz-se operar, portanto, outro dispositivo, sendo necessário nomeá-lo.

Neste texto, passa a se apresentar como políticas de subjetivação, pois faz ver e falar determinadas práticas de produção de sujeitos e conduz a novas formas de se constituir como humanos. $\mathrm{O}$ interesse é pelos agenciamentos ${ }^{18}$ e conexões que possibilitam observar processos de constituição de subjetividades segundo a dupla atribuição da palavra sujeito: sujeição/subjetivação (Foucault, 1988; Butler, 1997; Carvalho, 2007).

Nas técnicas de modificações corporais, que não se reduzem ao processo transexualizador ${ }^{19}$, há subversões na matriz hegemônica de identidade como resistência aos regimes hegemônicos de subjetivação. A pessoa trans pode ainda buscar o seu ajustamento social e uma harmonia entre sua expressão corporal e sua concepção de si. Assim, o processo de adequação do sujeito para si e para o outro pode ser ressaltado como um dos principais motivos que levam a realização da retificação de nome e de gênero nos registros de identificação ou ainda na cirurgia de redesignação sexual. No entanto, é importante salientar que as subversões às matrizes hegemônicas se dão em práticas de resistência e de autocriação ativa para transformar a situação de vulnerabilidade social.

O diagrama de Foucault, realizado por Deleuze (2013b) sobre os processos de subjetivação, traz algumas indicações sobre o manejo dessa tese. Trata-se de uma ilustração em que se pode visualizar, através do conceito de dobra, a constituição da subjetividade a partir de dois lados: o lado de dentro e o lado de fora, em que o lado de dentro - o si do sujeito - emerge de uma exterioridade.

18 Para Deleuze, o agenciamento significa "uma multiplicidade que comporta muitos termos heterogêneos e que estabelece ligações, relações entre eles, através das idades, sexos, reinos - de naturezas diferentes. Assim, a única unidade do agenciamento é o co-funcionamento: é a simbiose, uma "simpatia" (Deleuze \& Parnet, 2013b, p. 84)

19 O Processo Transexualizador realizado pelo Sistema Único de Saúde diz respeito ao atendimento de saúde a pessoas trans, incluindo acolhimento e acesso aos serviços do SUS, desde o uso do nome social, passando pelo acesso a hormonioterapia, até a cirurgia de adequação do corpo biológico à identidade de gênero e social. Retirado de: http://portalsaude.saude.gov.br/index.php/o-ministerio/principal/secretarias/1174sgep-raiz/lgbt/21885-processo-transexualizador. 
O conceito de dobra desenvolvido por Deleuze mostra que há, no texto de Foucault, um importante debate teórico sobre como a psicologia ${ }^{20}$ pode entender o modo de constituição da subjetividade. Quando Foucault elabora a perspectiva do cuidado de si em sua obra, por exemplo, não trata esse "si" de forma individual e genérica, pois o cuidado só é possível dentro de uma cultura de "si" em diferentes maneiras de praticar a atividade ética. Consoante tal leitura, não faz sentido a separação entre o que acontece no indivíduo e no coletivo em entidades antagônicas. Há, de outra forma, agências e modos de atravessamentos entre essas duas formações.

É possível visualizar esse manejo conceitual da relação entre sujeito e cultura concebido por determinadas perspectivas em psicologia, pode-se citar a de Vygotsky ou ainda a de Bakhtin. São visões importantes, inseridas num pano-de-fundo marxista, mas não serão tratadas neste texto por um motivo principal. No esforço de avançar no debate sobre questões contemporâneas à psicologia do desenvolvimento, visou-se construir um novo quadro teórico-metodológico.

As dinâmicas que ocorrem entre os níveis pessoal e grupal, de um ponto de vista topológico, podem ser expressas pelos processos e pelas práticas de subjetivação. Existe uma relação dos conceitos entre si, pois, embora não sejam sinônimos, possibilitam pensar como as subjetividades são produzidas por determinados regimes de signos e dispositivos técnicos e institucionais. É relevante pontuar que tais concepções não se limitam a uma análise restrita a uma esfera discursiva, pois os processos de subjetivação estão articulados a mecanismos sócio-técnicos efetuados, também, em planos singulares. Estes se organizam mediante práticas que se originam e se envolvem no âmbito de uma máquina microssocial, o sujeito e suas técnicas de si.

Desse modo, as relações do sujeito com os modos de auto-governo, a partir de normas sociais, podem ser concebidas como práticas de si, quando, apesar das distintas formas de governamentalidades, é possível tecer estratégias para não conceber a si como tão assujeitado assim. À princípio, pode-se dizer que se trata do desenvolvimento de exercícios a fim de serem criadas práticas de resistências aos padrões sociais hegemônicos. Conforme a concepção de uma moral foucaultiana, podem ser tecidas resistências à cisheteronormatividade como uma forma diferenciada de governar a si, por isso ser ou se tornar trans é uma atitude ética e um recurso estético de emergência de "si" enquanto um importante sujeito político na contemporaneidade.

Essas análises preliminares possibilitam contextualizar a organização de conceitos centrais do trabalho. Trata-se de uma proposta que apresenta um interesse, no sentido teórico-prático, de propiciar visibilidade a autores/as considerados marginais no âmbito da psicologia do desenvolvimento e, com isso, também inaugura um novo campo problemático. Nesse enquadre, toma-se como ponto de partida o questionamento de perspectivas hegemônicas. O resultado é

20 Mas ressalto que seria interessante colocar no plural, as psicologias, por entender que se trata de um domínio científico com uma gama variável de tradições, que podem ser conflitantes, mas se mantêm como paradigmas paralelos ao longo de sua história. A própria teorização realizada nesta tese reconhece a pluralidade de paradigmas em que a psicologia do desenvolvimento pode se desenvolver. 
conceber um tema pouco abordado por essa ciência psicológica, a saber: a experiência de subjetivação no que diz respeito ao gênero e à sexualidade, com o cuidado de não tecer perspectivas que retroalimentem as relações de poder.

O conceito subjetivação é tratado dentro de um sistema teórico, como um termo guardachuva, para falar sobre as dinâmicas de identificação, o desenvolvimento psicológico numa perspectiva processual, a ação ética de si para si e ao outro, entre outros. A subjetivação pode também assumir um caráter genético, em que se considera a atuação das forças geradoras de desenvolvimento ou produtoras de processos. Pode-se observar aí a existência de elementos micro-genéticos que são, em geral, importantes fontes de análise para a psicologia. Dessa forma, é possível entender o sujeito a partir de sua singularidade sem ser reduzido ao individual, sendo que o singular se dá como efeito da individuação do sujeito segundo diferentes formas de autoprodução.

A composição diagramática dos processos de subjetivação consiste em uma cartografia em que pode ser ilustrado um desenho ou uma configuração dos modos de subjetividade e de suas formações a partir dos dispositivos - as práticas sociais e as máquinas sócio-técnicas - e dos jogos de verdade.

O recurso imagético que aparece como um diagrama é a noção de dobra, que decorre da força vergada da relação de afeto de si para consigo situada em um determinado registro topológico. A dobra diz respeito a um princípio de regulação interna do sujeito, já que esse lado de dentro não se trata de uma individualidade cognoscente e autocentrada, conforme se sustentou anteriormente, mas de um processo de auto-referência de si diante do poder e seus duplos, os discursos e as práticas extra discursivas. Esses se configuram por uma série de relações de força, que também se dobram sobre o sujeito, transformam-se em dispositivos concretos e apresentam um determinado modo de funcionamento.

Para Deleuze (2013b), "a obsessão constante de Foucault é o tema dos duplos. Mas o duplo não é nunca uma projeção do interior, é, ao contrário uma projeção do lado de fora. Não é o desdobramento do Um, é uma reduplicação do Outro" (p. 105). O interior não é uma reprodução do exterior, mas se deriva de um processo diferenciação: "sou eu que me vejo como duplo do outro: eu não me encontro no exterior, eu encontro o outro em mim" (p. 105).

E o si, o ser-si, é determinado pelo processo de subjetivação, isto é, pelos locais por onde passa a dobra. Em suma, as condições nunca são mais gerais que o condicionado, e valem por sua própria singularidade histórica. Por isso as condições não são "apodíticas", mas problemáticas. Sendo condições, elas não variam historicamente, mas variam com a história. O que elas apresentam, com efeito, é a maneira através da qual o problema se coloca em tal formação histórica: que posso eu saber, ou que posso ver e enunciar em tais condições de luz e de linguagem? Que posso fazer, a que poder visar e que resistências opor? Que posso ser, de que dobras me cercar ou como me produzir como sujeito? Sob essas três questões, o "eu" não designa um universal, mas um conjunto de posições singulares ocupadas num Falase, Vê-se, Combate-se, Vive-se (Deleuze, 2013b, p. 122).

A subjetivação, então, faz-se por quatro dobras ou pregas. A primeira se trata da parte 
material de nós mesmos que se constitui pela superfície da dobra, é a nossa pele, corpo e seus prazeres. A segunda é a da relação de forças e de poder segundo as quais é vergada para constituir a relação do sujeito consigo, diz respeito aos códigos morais e normativos que produzem essa relação; ao mesmo tempo, nessa dobra, são tecidas técnicas de resistência. A terceira é a do saber, a dobra da produção da verdade, por se tratar do contato do sujeito com o que há de verdadeiro em seu ser e servirá para o conhecimento de si, do outro e do mundo; é um eixo de subjetivação do conhecimento por via de uma verdade teológica, filosófica ou ética. A quarta dobra é o lado de fora do qual se deriva, é o conjunto de forças que circunscrevem a própria condição humana. Por sua vez, o lado de fora não é um limite fixo, mas uma matéria móvel e contingencial. As quatro dobras dizem respeito, então, ao status material da subjetividade e a causa formal da relação do sujeito consigo. Essas dobras são variações e funcionam por meio de diferenciados ritmos, sendo que essas variáveis compõe os modos de subjetivação (Deleuze, 2013c; Rose, 2011).

Deleuze (2013b) visualizou o diagrama da subjetivação, a partir das ideias de Foucault, da seguinte forma:

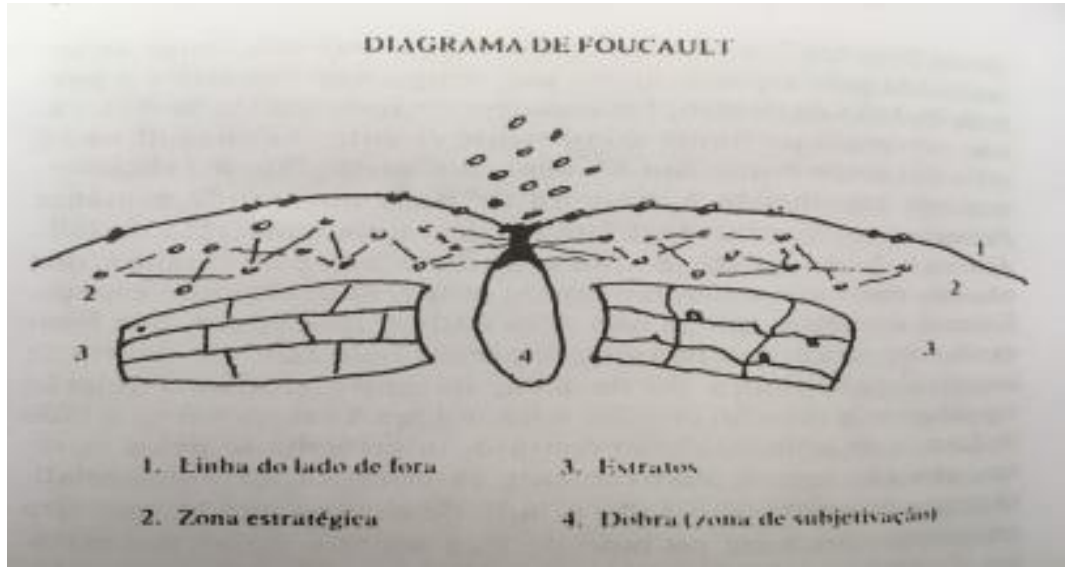

Diagrama 2. O Diagrama de Foucault por Deleuze (2013b).

Procurar-se argumentar como os processos de subjetivação, composto por pregas e fendas (tal como salientado anteriormente), podem se articular com as dimensões de tempo e de gênero. $\mathrm{E}$ se, na verdade, essas são partes integrantes das dobras. A subjetivação deriva de agenciamentos heterogêneos "de corpos, vocabulários, julgamentos, técnicas, inscrições e práticas" (Rose, 2011, p. 235). Nesse sentido, o mais importante é observar a rede de conexões entre elementos processuais e, assim, será possível tecer uma argumentação sobre tais partes constituintes de nossas subjetividades.

Para Deleuze (2013b), a memória é o tempo que se constitui como processo de subjetivação, pois emerge da relação do sujeito consigo e da relação afetiva de si para si; o tempo é auto-afeição, formando "a estrutura essencial da subjetividade" (Deleuze, 2013c). É, então, uma dobra que se reduplica. E quando se torna uma dobra do lado de fora possibilita que o presente seja esquecido, havendo a manutenção do passado na memória; o esquecimento não permite o retorno do sujeito, mas a memória concede um recomeço. Pensa-se o lado de fora como tempo, sob a condição de dobra 
(Deleuze, 2013c).

O gênero, por sua vez, é delineado pelos agenciamentos que ligam o "lado de fora" e o "lado de dentro" (Rose, 2011). Deriva de maquinações e de tecnologias advindas (Lauretis, 1987) de uma série de regimes de signos e de normas, marcando os corpos dos sujeitos. O gênero é produto de atos performáticos $^{21}$ (Butler, 1997; 2013a; 2013b; Salih, 2012), inscreve-se na superfície dos nossos corpos e produz certos tipos de subjetividades - ser-agenciado-junto a partir de determinados instrumentos, técnicas de si e dispositivos linguísticos. Tais indicações serão trabalhadas e aprofundadas ao longo dessa seção.

Para essa primeira parte, mediante a noção "práticas de subjetivação", o trabalho visa situar a relação do sujeito-consigo quando é posicionado na relação com o outro. O processo de constituição da subjetividade pode ser entendido como o modo pelo qual cada sujeito expressa-se no mundo segundo um particular ponto de vista. E esse processo é a própria diferença que se enreda e se dobra no sujeito, contorna-se sobre si mesma e constitui a subjetividade. Além disso, as práticas de subjetivação dizem respeito às dinâmicas pelos quais os sujeitos se identificam com as posições pelas quais estão situados.

As formações discursivas articulam posições de sujeito por meio de termos normativos e regulatórios, assim sendo, os sujeitos regulam a si mesmos e negociam a produção e o exercício dessas posições. É preciso ainda compreender como os sujeitos se posicionam, constroem concepções acerca de si mesmos e se identificam a determinadas posições "identitárias" (Hall, 2007). Nesse sentido, é possível dizer que o ato de se nomear a si como trans, no intercurso das técnicas de si, derivam de práticas de transgressões corporais às normas hegemônicas cisnormativas e ao regime do binarismo de gênero. Estes podem ser vistos como formas de violência institucionalizadas derivadas de gestões biopolíticas contra os corpos que se desenvolvem e se auto-produzem enquanto plurais.

\subsection{O que são práticas de subjetivação?}

Para discorrer sobre a ideia de práticas de subjetivação, tornou-se necessário recorrer à perspectiva de Foucault (1984; 1988; 2006a; 2006b; 2010a; 2010b; 2012; Jay, 2004; Pélbart, 2013), pois permite a construção de uma análise acerca das estratégicas posições de sujeitos, que estão sendo constituídas no cronotopo contemporâneo, levando em consideração o diagrama de Foucault, por meio do conceito de dobra, descrito acima.

A intenção é abordar sobre a produção de subjetividades no cenário contemporâneo a partir de um paradigma de análise foucaultiano, pois o sujeito pode ser concebido a partir de uma perspectiva processual. Além disso, a produção de si por meio do gênero, em experiências trans,

\footnotetext{
${ }^{21} \mathrm{O}$ conceito de performatividade e de atos performáticos serão explicados na seção sobre a teoria de Butler.
} 
pode ser vista de forma dinâmica, e, integrada numa dimensão temporal da narrativa, estabelece-se de acordo com uma organização variável e instável. As narrativas de si, mediante a construção de processos ficcionais diante de experiências vividas, podem mostrar a potência discursiva dos processos de subjetivação que se transformam ao longo da história de uma existência.

Em uma significativa parcela da obra de Foucault (1997) existe uma abordagem de temas relacionados à psicologia como a questão da saúde mental, da sexualidade e das técnicas de cuidado de si, entre outros. Pode-se questionar como seriam realizadas ou desenvolvidas as práticas de cuidado de sujeitos (éticos) na contemporaneidade, se ou em psicoterapia, diga-se em psicanálise, ou em práticas espirituais ${ }^{22}$.

Tanto pela sua proximidade do autor com a área quanto pelas suas relevantes contribuições sobre os processos de autorreflexividade na subjetivação de seres humanos, pensa-se em incorporar a sua perspectiva no âmbito da psicologia do desenvolvimento. Para Morss (1992; 2002), segundo as visões tradicionais que visam observar regularidades e padrões, tratam-se de perspectivas críticas e de desconstrução do desenvolvimento como um processo linear. O trabalho pós-estruturalista, mais entendido como uma perspectiva que inspira a psicologia crítica, não está contaminado por afirmações disseminadas sobre a existência dos padrões típicos de desenvolvimento.

Em um primeiro momento, Foucault pode aparecer como crítico das ciências positivistas de um modo geral e, por conseguinte, de uma determinada concepção hegemônica de desenvolvimento. A sua análise histórica das práticas discursivas e extra discursivas pode ser vista como uma leitura macro do desenvolvimento humano, pois sustenta que os processos de subjetivação são socialmente fabricados. De fato, o que se pode sugerir como padrões são as técnicas de uniformização utilizadas para conferir uma lógica de organização consoante um determinado processo de desenvolvimento (Morss, 2002; Walkerdine, 1993). Subjetividades e qualquer mudança em subjetividades que é associada à idade ou ainda à temporalidade é melhor concebida como produzida a partir de determinados dispositivos sócio-técnicos e institucionais. Ariès (1989), em A história social da infância e da família, por exemplo, pontuou que a infância foi construída em determinado período histórico-cultural.

Pois bem, evidencia-se a relevância do trabalho teórico de Foucault à psicologia do desenvolvimento por alguns motivos principais, a saber: quando o autor analisa os modos como os sujeitos concebem a si e aos outros, crianças, jovens ou adultos, observa que não há, na história ou

22 Allouch (2014), leitor de Lacan e de Foucault, argumenta se o estatuto da psicanálise poderia ser considerado um exercício espiritual, já que, para ele, não é uma psicologia, nem ciência, nem arte, nem religião. Sabe-se que as relações de Foucault com a psicanálise são, em momentos particulares de seu texto, tensas. Especificamente, em A hermenêutica do sujeito, houve uma reconsideração do papel da psicanálise e, ainda que de um modo cauteloso, passou a lê-la não como uma ciência, mas como a possibilidade de um exercício espiritual. Sendo assim, Allouch (2014) salienta que "a psicanálise não soube, notava Foucault, pensar-se 'no divisor histórico da existência da espiritualidade e das suas exigências'. Por conseguinte, ela teria embarcado na amnésia quanto àquilo mesmo que ela é: uma experiência espiritual, pela qual, via um outro, o sujeito opera nele mesmo as transformações necessárias para ter acesso à sua verdade" (p. 32). 
no desenvolvimento, um elemento em comum que pode ser amplamente compreendido como natural. Assim, pode-se dizer que ele dissolve as noções dominantes de continuidade e de naturalidade do desenvolvimento, das pessoas e das culturas, e coloca-as em um patamar de análise histórico, também entendido como regime de verdade. Ou seja, para ele, não existe uma condição humana genérica que se desenrola através do tempo e do espaço; qualquer mudança no curso de vida deriva de eventos contingenciais e de desdobramentos da condição humana. Por isso, não se pode referir à existência de estágios e de sequências universais do desenvolvimento e nomeá-las como "o curso de vida”. Os estágios universais são apenas domínios de conhecimentos, interpretações científicas ou ainda práticas discursivas e extra discursivas realimentadas pelo senso comum e pelos sistemas de poder (Morss, 2002; Walkerdine, 1993). As críticas de Foucault sobre o desenvolvimento no contexto da história convergem com suas análises sobre a produção da subjetividade (Rose, 2011).

A partir de um exercício metateórico, a integração de argumentos do autor, especialmente em termos de suas avaliações e diagnósticos, pode ser importante para o incremento da disciplina. Por esse motivo, objetiva-se situar a influência da teoria crítica ${ }^{23}$ (Butler, 1993; Foucault, 2000; Derrida, 2008; Spivak, 2010) no âmbito da psicologia. Consequentemente, poderíamos discutir em termos de uma psicologia do desenvolvimento crítica (Morss, 1992; 2002; Walkerdine, 1993; 2013; Henriques et all, 2002; Burman; 2008; 2010; 2011; 2015; 2016).

A problemática da experiência da subjetividade se configurou como um tema central nas investigações de Foucault, é teorizada a partir dos modos instituídos do conhecimento de si na história vistos como “técnicas de sì". Para ele, o sujeito se produz como efeito de práticas discursivas e extra discursivas, por isso a sua preocupação principal foi “levar a cabo uma 'história do sujeito' ou, antes, o que denomina modos de subjetivação" (Edgardo, 2009, p. 407).

Ele utiliza o método da pesquisa arqueogenealógica para poder traçar os elementos vinculados a como a subjetividade vem sendo construída durante a modernidade ocidental: "como a experiência que se pode fazer de si mesmo e o saber que se pode fazer de si mesmo, e o saber que deles formamos, foram organizados através de alguns esquemas? Como esses esquemas foram definidos, valorizados, recomendados, impostos?" (Foucault, 1997, p. 109) O ser humano constrói a sua experiência envolvido dentro de um processo que, por meio de um campo de objetos, ao mesmo tempo, muda-o e transforma em sujeito (Jay, 2004).

O objetivo de Foucault consistiu, portanto, em apresentar como as práticas sociais forjam áreas de saber e ainda fazem aparecer novos objetos de investigação, novos conceitos, novas técnicas, "mas também fazem nascer formas totalmente novas de sujeitos e de sujeitos de conhecimento". Logo, "o próprio sujeito do conhecimento tem uma história, a relação do sujeito com

23 Em filosofia, a teoria crítica é considerada a Escola de Frankfurt. Em ciências humanas, de forma mais abrangente, a teoria crítica pode ser definida como a filosofia continental ou as perspectivas que derivam do pós-estruturalismo, como, inclusive, os estudos pós-coloniais. 
o objeto, ou, mais claramente, a própria verdade tem uma história" (Foucault, 2002, p. 8).

O "pessoal" é fruto de uma fabricação inteiramente histórica. A forma da experiência de "loucura", num sentido restrito da palavra, só pode ser compreendida se não for reduzida ao seu aspecto privado, mas devolvido à sua historicidade (...) A experiência, nesse caso, por mais vívida e autêntica que pareça ser, não pode ser naturalizada, ela deve ser historicizada, devolvida a rede de saberes e poderes, para dizê-lo de maneira mais simplificada, que a elucidem, e que, para formulá-lo de maneira ainda mais paradoxal, digam a "verdade" dessa experiência (Pelbart, 2013, p. 211)

A condição histórica da experiência (Benjamin, 1933/1987; Foucault, 1997; 2006b) situa o sujeito e sua vida cotidiana, pois são produzidas entre o ponto de vista coletivo e o biográfico. Do mesmo modo, a experiência não é uma realidade dada ou pré-determinada, mas se trata de um processo histórico-cultural. A experiência social agencia as produções singulares e locais da subjetividade e, ao mesmo tempo, é agenciada por elas ${ }^{24}$. É nesse sentido que os processos de subjetivação podem assumir diferentes configurações a partir de distintos modos de vida e de organizações sociais, mas cabe a pergunta: como os modos de subjetivação transformam-se no decorrer da história?

Há em cada época histórica regimes hegemônicos de subjetivação em que emergem critérios para definir e diferenciar os sujeitos, tais critérios funcionam como dispositivos, pois agenciam modos de ser e de estar no mundo. Além disso, organizam-se como dispositivos porque servem para incluir, mas também para excluir; é, dessa forma, que subjetividades têm sido historicamente excluídas de discursos, de práticas e de normas sociais. Hoje vivemos num período de transição social, política e cultural que gera efeitos sobre o modo como passamos a nos conceber enquanto sujeitos. Consequentemente, é possível dizer que em nosso cenário contemporâneo há transformações nos regimes de subjetivação existentes. Tais mudanças proporcionam o surgimento de novos grupos sociais, em especial os sexuais e de gênero, que se articulam politicamente e demandam direitos em conformidade com essas transformações.

Ao trabalhar a história do sujeito e dos processos de subjetivação, o ponto de partida foucaultiano foi sendo modificado ao longo de sua obra. Primeiro pela epistemologia das ciências humanas para depois tematizar os dispositivos de poder e, por fim, às práticas de si mesmo. Ele é autor recursivo, ou seja, trabalha as suas teses e os seus conceitos, ao mesmo tempo que os reelabora ao longo de sua obra. Por exemplo, em A história da sexualidade - a vontade de saber continua seu trabalho sobre a noção de poder como produção e incitação para apontar novas indicações mediante os conceitos de biopoder, biopolítica e governamentalidade. O poder age não como repressão ou punição, mas a partir de um agenciamento, efetuando-se entre as relações humanas numa tensão de forças. Assim, não se trata somente de um poder de Estado, um macropoder que interfere sobre a vida dos indivíduos, mas de um biopoder que emerge das próprias práticas de governamentalidade.

24 Tanto a experiência social quanto a experiência singular são agenciadas mutualmente. Ou seja, elas se constituem a partir de um modo de co-funcionamento e são vistas como inseparáveis, portanto. 
Existem três modos de subjetivação/objetivação trabalhados em sua obra. Primeiro, em As palavras e as coisas (Foucault, 2000) aparece uma investigação que avalia a objetivação do ser humano enquanto ser falante, vivo e trabalhador na emergência das ciências humanas. Segundo, em A História da Loucura e Vigiar e Punir, dentre outros trabalhos, o sujeito é analisado a partir das práticas e dos modos de sujeição que foram instituídos pelos dispositivos de saber-poder. Terceiro, nos três volumes de A história da sexualidade e nos cursos do Collège de France, o autor trabalha a maneira pelo qual o ser humano se transforma como sujeito de sua própria experiência.

Tal divisão de sua obra pode ser representada da seguinte forma: ser-saber; ser-poder; serconsigo. Como Foucault entende essa constituição do ser humano pelo conhecimento (ser-saber), pela ação de uns sobre os outros (ser-poder), e pela ação de cada um consigo próprio (ser-consigo). Como nos constituímos como sujeitos de conhecimento; como sujeitos que se relacionam social e politicamente entre si; como sujeitos da ação moral sobre nós mesmos. A partir disso, "acentua-se o elemento dinâmico dos modos de subjetivação: as formas de relação, os exercícios pelos quais o sujeito se constitui como objeto de conhecimento, as práticas que permitem ao sujeito transformar seu próprio ser" (Edgardo, 2009, p. 408).

Nesse sentido, o autor vai conduzindo a uma história das práticas nas quais o sujeito aparece como efeito de sua constituição. O sujeito não é uma substância egológica e universal, mas resulta dos processos de subjetivação através de práticas de si (Edgardo, 2009). Este "si" é uma zona relacional de constituição da subjetividade, que está "na passagem entre uma modalidade de assujeitamento para uma modalidade de autocontrole, no sentido de governamentalidade" (Pelbart, 2013, p. 232). Diante disso, diz respeito ao desenvolvimento mútuo dos modos de objetivação/subjetivação do sujeito em que ele aparece como "objeto de uma determinada relação de conhecimento e poder" e, dessa forma, é por meio dos jogos de verdade que pode se tornar objeto do conhecimento científico (Foucault, 2000).

A noção de experiência, em Foucault, é entendida como uma correlação entre formas de conhecimentos, tipos de normatividade e as formas de subjetividade numa determinada cultura. Essas são produções históricas da experiência em "diferentes modalidades de subjetivação, de relação a si ou de modificação de si, cabe a ela produzir, por assim dizer, a subjetivação que lhe corresponde" (Pelbart, 2013, p. 222). Há a possibilidade dessas diferentes práticas implicar uma transformação de si como um abandono de si e originar processos de dessubjetivação, como em casos de experiências-limite. Tratam-se de vivências de constantes assujeitamentos ou de perdas de referências, como nos campos de guerra. Ou ainda quando a auto-reflexividade emerge do discurso do limite, da ruptura e transgressão da subjetividade, essa experiência pode inaugurar uma nova forma de vida a partir de uma ressubjetivação. Por sua vez, a experiência interior ou a experiência do fora pode se mover de uma auto-negação que culmina da loucura, do excesso sexual ou do próprio limite da experiência que é a morte (Jay, 2004).

Ser um sujeito, pois, apenas na medida de uma necessidade estratégica ou tática, princípio 
útil em todos os domínios onde uma prática de si tangencia uma zona de não conhecimento ou de dessubjetivação, onde um sujeito assiste ao seu colapso ou roça a sua dessubjetivação (...) o risco é que se reidentifique, que se invista essa situação com uma nova identidade, que se produza um sujeito novo, seja, mais assujeitado ao Estado, e que se reconduza desde logo, apesar de si, esse processo infinito de subjetivação e de assujeitamento que justamente define o biopoder (Pelbart, pp. 226-228).

Assim sendo, o ser humano está sujeito a um variável conjunto de técnicas discursivas que anseiam dizer uma verdade acerca dele (Foucault; 2010a). O seu principal elemento de análise passa a ser a relação entre verdade e constituição da subjetividade. Essa produção da verdade se organiza em função de certos regimes, num a priori histórico, segundo regularidades discursivas e os aparatos de poder que os subjazem. Tanto nos discursos científicos, jurídicos, médicos ou ainda nas normas sociais, o sujeito vive um processo de subjetivação baseado em uma série de verdades estabelecidas. Por meio de suas análises, compreende-se a importância de levar em consideração os dispositivos que permeiam esses jogos de verdade, "tivessem estes a forma de uma ciência ou se referissem a um modelo científico, ou fossem como os encontrados nas instituições ou nas práticas de controle" (Foucault, 2010a, p. 264).

Foucault analisa as condições concretas de constituição do saber científico e constrói um olhar diferenciado sobre o desenvolvimento do conhecimento humano a partir da relação entre verdade e subjetividade pensadas como produção. Diante disso, a história passa a ser o ponto de partida onde ocorrem os acontecimentos da verdade, há, então, sempre uma perspectiva de verdade, sendo que esta é vista como um acontecimento. Para fundamentar suas ideias, Foucault apoia-se no pensamento de Nietzsche (19873/2007), que em A verdade e a mentira no sentido extra-moral ${ }^{25}$, denuncia sobre como a concepção tradicional de verdade foi constituída e, portanto, não passa de um preconceito moral inventado para validar a hegemonia de determinados valores. Esse é o cerne de um pensamento que pode ser considerado pós-estruturalista, pois a verdade, para ambos os filósofos, organiza-se de modo a legitimar quem pode dizer a verdade,

por isso mesmo, seria preciso examinar as condições concretas de possibilidade de produção da verdade, inscrevendo-a na tessitura do espaço social e da história, para que se pudesse surpreender em estado nascente os processos de produção do verdadeiro e as modalidades de efetivação de sua legitimidade (Birman, 2002, p. 306).

Candiotto (2007, p. 215), estudioso do pensamento de Foucault, exemplifica que as ciências humanas só puderam se constituir a partir de um olhar voltado para a diferença considerada excluída. De acordo com um determinado modo de produção da verdade, pode-se situar o desdobramento da ciência psicológica em suas mais variadas abordagens (Foucault, 2006b). Ao ter tomado como domínio de estudo a loucura, a psicologia encontrou a verdade de um sujeito no enigma do louco que ele é não é, "cada louco traz e não traz em si essa verdade do homem que ele põe a nu na nascença

25 Retirado de http://imediata.org/asav/nietzsche_verdade_mentira.pdf, em 11 de dezembro de 2016. Tratase de um ensaio que foi publicado inicialmente em $187 \overline{3}$. 
de sua humanidade" (Foucault, 2013, p. 522); no surgimento da psicologia da memória, houve a preocupação com o exame das amnésias; a psicologia da linguagem, por sua vez, debruçou-se na correlação com as afasias; na da inteligência o foco passou a ser o estudo da deficiência mental, "a verdade do homem só é dita no momento de seu desaparecimento; ela só se manifesta quando já se tornou outra coisa que ela própria" (Foucault, 2013, p. 545) ${ }^{26}$.

Nos três livros sobre A história da sexualidade, o teórico mostra a passagem de uma leitura sobre a sexualidade como forma de poder, desenvolvendo uma nova noção de biopoder e biopolítica $^{27}$, nas estratégias de gestão sobre a vida e na experiência de si através das práticas de cuidado do sujeito ético. Portanto, apresenta em A vontade de saber sua tese de constituição da sexualidade, ao longo da história no ocidente, como produção de um poder através de três linhas principais de raciocínio: primeiro, o desenvolvimento da confissão cristã a partir do século XIII; segundo, a multiplicação de um certo tipo de discurso sobre a sexualidade; terceiro, a partir do século XVIII e, na mesma altura, a mudança de objetivos de poder cuja atuação procede cada vez mais em linhas ligadas à proliferação e reforço da espécie (Foucault, 1988).

Houve ao longo da história uma transformação das agências de poder. Da Idade Media à Moderna, o rei detinha um poder soberano, que "só exerce, no caso, seu direito sobre a vida, exercendo seu direito de matar ou contendo-o (...). O direito que é formulado como 'de vida e de morte' é, de fato, 'o direito de causar a morte e deixar viver'" (Foucault, 1988, p. 148). Um micropoder foi se tornando cada vez mais disseminado através dos procedimentos criados na sociedade disciplinar. A sociedade disciplinar surge com o nascimento das instituições, com a escola, os manicômios, as instituições penitenciarias e também o fortalecimento do poder do Estado. Isso aconteceu mais especificamente na Europa, ao longo do século XVIII até meados do século XX, e essas práticas disciplinares foram sendo transmitidas para sociedades ocidentais. Hoje passamos de uma sociedade disciplinar para uma sociedade do controle (Deleuze, 2010).

É possível dizer que os Estados modernos passaram a ter a função de gerir a vida: “o princípio: poder matar para poder viver, que sustentava a tática dos combates, tornou-se princípio de estratégia entre os Estados; mas a existência em questão já não é aquela - jurídica - da soberania; é outra - biológica - de uma população" (Foucault, 1988, p. 149). O poder do soberano foi sendo

26 Esse ponto é muito importante para se colocar em questão o estudo da transexualidade e da transgeneridade como um regime de inteligibilidade para se falar de dentro da psicologia.

27 O conceito de biopoder é utilizado por Foucault para situar a regulação das práticas dos estados modernos que atuaram, a partir da criação de variadas técnicas, no intuito obter a sujeição dos corpos e o controle das populações. O autor usou pela primeira vez esse conceito em A história da sexualidade, a vontade de saber e posteriormente nos seus cursos no Collège de France. Por sua vez, a concepção de biopolítica é utilizada por Foucault para descrever a forma que o poder foi assumindo no final do século XIX e início do século XX. Anteriormente, o poder disciplinar tinha como objetivo o governo dos indivíduos, a biopolítica, por sua vez, visa atingir o controle do conjunto de indivíduos, da população. A biopolítica tem como alvo o controle da vida e é aplicada como um sistema de normatização dos corpos e dos comportamentos dos sujeitos. 
substituído pelo poder de causar a vida e devolver a morte. Isso porque foram se desenvolvendo tecnologias agrícolas e medicinais tanto que a morte deixou de ser iminente. Então, o poder do soberano foi sendo substituído pela administração dos corpos e pela gestão calculista da vida, com o aparecimento das práticas políticas e observações econômicas - problemas de natalidade, saúde pública e migração - sob a forma de um biopoder que visava controlar as populações através do controle dos corpos e das práticas de sujeição.

No entanto, o autor rejeita a ideia de que o Estado seria a fonte de onde provêm os poderes periféricos e a instituição que legitima a sua existência. Pelo contrário, o Estado é legitimado pela existência anterior desses poderes e surge a partir deles. São os poderes descentralizados e locais que sustentam a existência de uma instituição estatal. O Estado não é a fonte central do poder, mas sim uma matriz de individualização sobre a qual cada um tem constituído subjetividades ou realiza ações na vida diária. O poder se exerce no Estado, mas não deriva dele; pelo contrário, o poder se estatizou ao se abrigar e se legitimar sob a tutela das instituições estatais (Veiga-Neto, 2003). O autor aproxima a análise do poder das micro-relações cotidianas. É nesse contexto periférico de jogos de força que o poder opera a todo momento concretamente. Difuso por todo o corpo social, o poder perpassa todas as relações humanas e não lhes é externo. Em vez de ter a única função reprimir, como se concebe na soberania, o poder é quem produz. Ele perpassa os corpos, os sujeitos, as instituições, organizando-os e criando formas de existência.

É por meio dessa mesma linha de raciocínio que se pode observar sob que condições os discursos de poder tentam penetrar as mais íntimas condutas dos seres humanos. Em geral, ele consegue interferir nas práticas de si e controlar o corpo e os prazeres dos sujeitos, "tudo isso com efeitos que podem ser de recusa, de bloqueio, desqualificação, mas, também, de incitação, de intensificação, em suma, de técnicas polimórficas de poder" (Foucault, 1988, p. 18). Foucault busca compreender se essas produções discursivas e seus dispositivos de poder permitem que seja tecida uma verdade do sexo por uma vontade de saber que lhe serve de base. Depois do século XVI, houve uma sucessiva recolocação do "sexo em discurso" e os procedimentos de poder buscou constituir, incessantemente, uma ciência da sexualidade.

Dessa forma, Foucault desenvolve, a partir de uma contra-hipótese, o conceito de dispositivo da sexualidade. Ao contrário de ter existido um processo constante de repressão da sexualidade, a partir do séc. XVI, foram multiplicados os discursos de incitação produzidas pela scientia sexualis. Esses discursos não tinham por objetivo reprimir o comportamento das pessoas, mas o de controlálas. Enquanto no mundo oriental, havia um saber sobre o sexo a partir de uma ars erótica para intensificar o uso dos prazeres, no ocidente, esse saber advém do prazer em controlar a sexualidade dos sujeitos. Inventou-se um outro prazer: "o prazer da verdade do prazer, prazer de sabê-la, exibila, descobri-la (...) prazer específico do discurso verdadeiro sobre o prazer” (Foucault, 1988, p. 81). Os discursos sobre o sexo aparecem como produto de uma forma de poder, inclusive, de um poder sobre a vida. 
Laqueur (2001) reforça a tese foucaultiana sobre a constituição de uma ciência em torno do sexo. $\mathrm{O}$ autor tece uma hipótese de que o desenvolvimento dessa ciência passou de uma perspectiva de isomorfismo para o dimorfismo sexual. Nos estudos realizados nos séculos XVI e XVII, a genitália feminina era comparada com a genitália masculina e era subtraída de suas referências diferenciadas, ou seja, o clitóris era comparado ao pênis e considerado um órgão genital masculino inferior. Tratava-se, então, de uma visão de um único sexo - isomórfico. Só depois que as diferenças passaram a ser avaliadas como importantes a partir da existência de dois sexos e essas diferenças se tornaram politicamente relevantes. Só em 1759 é representado detalhadamente um esqueleto feminino num livro de anatomia para ilustrar as diferenças do masculino. Até essa época havia uma estrutura básica do corpo humano - a masculina. E quando as diferenças foram descobertas já eram, na própria forma de representação, profundamente marcadas pela política de poder de gênero.

É importante que se compreenda essa sexualidade como construída discursivamente por meio de vários agenciamentos e das relações que vão sendo efetuadas em nossas subjetividades. Esse saber sobre a sexualidade possibilita a apropriação ou não dos discursos. A scientia sexualis foi sendo produzida ao longo da modernidade e teve por função circunscrever as várias formas de sexualidades existentes: produziu-se um discurso sobre a mulher histérica, sobre a criança e o adolescente masturbador, o adulto perverso, a homossexualidade, o fetichista, enfim, catalogou-se as diversas manifestações da sexualidade com a intenção de controle sobre elas (Foucault, 1988). Não se trata de uma simples exclusão de sexualidades, mas de demarcação e de enquadramentos de suas expressões pelos indivíduos. E isso reflete sobre o contexto em que estamos, houve uma implementação da diversidade sexual através da autoridade do discurso sexual científico.

Nesse sentido, o dispositivo da sexualidade se instaura mediante as técnicas de confissão científicas "ora, através da ciência, a autoridade do ouvinte intensifica-se, não se trata agora apenas de ouvir a verdade e a julgar, mas de construir a própria verdade a partir do discurso de quem confessa" (Foucault, 1988, p. 77). Essa noção de que havia uma verdade oculta e que era preciso revelá-la e interpretá-la deu ao sexo a importância central que tem hoje. Tanto na confissão cristã como nas tecnologias médicas, a revelação da verdade tem o poder de curar, a pess oa que escuta a confissão será uma autoridade que assume a posição de saber sobre uma determinada verdade, sustenta Foucault (1988). Além disso, ele pontua que o sexo ou a nossa sexualidade está cheia de mistérios, quando se fala sobre ela tem o objetivo de descobrir qual é a verdade da experiência:

Declarar alto e bom som e de maneira inteligível a verdade acerca de si próprio - isto é, confessar - foi durante muito tempo considerado no mundo ocidental uma condição de redenção dos próprios pecados, (...) reside no facto de que uma das mais importantes obrigações morais ser, para qualquer sujeito, o conhecer-se a si próprio. A obrigação dos indivíduos à verdade e à consequente organização científica do conhecimento. Dedico-me, antes, a uma história da ciência que, em certa medida, é uma história regressiva que procura descobrir as práticas discursivas, institucionais e sociais a partir das quais essas ciências irromperam. Este projeto procura descortinar o ponto em que essas práticas se tornam técnicas reflexivas coerentes com objetivos definidos, o ponto em que um discurso particular emergiu de tais técnicas e passou a ser visto como verdadeiro, o ponto em que elas se ligam 
à obrigação de procurar a verdade e dizer a verdade. A finalidade do meu projeto é construir uma genealogia do sujeito. O método é uma arqueologia do conhecimento e o domínio exato da análise é aquilo a que eu daria o nome de tecnologias (Foucault, 1993, p. 2-4).

Em vista disso, o autor estabelece a relação entre verdade e subjetividade na emergência do sujeito ético e discorre sobre o desenvolvimento das práticas de si. A problemática dos jogos de verdade pode ser concebida na passagem das práticas de dominação sobre os sujeitos vulneráveis e espoliados de predicados ${ }^{28}$ à análise das práticas de formação desses mesmos sujeitos sobre si: "um exercício de si sobre si mesmo através do qual procura se elaborar, se transformar e atingir um certo modo de ver" (Foucault, 2010a, p. 265).

Consoante a chave de análise foucaultiana, pode-se pontuar que os modos de subjetivação estão circunscritos em determinadas matrizes de racionalidades e regimes específicos de governamentalidade. Assim sendo, os sujeitos só podem reconhecer a si e aos outros em determinados regimes de verdade e de inteligibilidade (Butler, 2015).

A sua abordagem histórica se opôs claramente a perspectiva cartesiana e, por isto, colocou o problema do sujeito mediante a questão histórica da forma-sujeito que "não é uma substância, mas uma forma que não é, sobretudo, nem sempre, idêntica a si mesma" (Foucault, 2010a, p. 275). Esta proposição foucaultiana se insere numa perspectiva de subjetividade para além dos limites de toda e qualquer produção de identidade autocentrada. Foucault pontua a relação do sujeito consigo como política, social e pública, "sustentada inevitavelmente no contexto de normas que regulam as relações reflexivas" (Butler, 2015, p. 147).

É nesse sentido que Foucault $(1985$; 2006a) trabalha, sob o prisma de uma ética e estética da existência, a concepção de "cuidado de si”, vocabulário traduzido da expressão epiméleia heautoû, que foi encontrado pela primeira vez na obra Alcibíades II de Platão. É importante colocar em evidência uma concepção de intersubjetividade no cuidado de si, pois o outro assume uma inegável importância, seja por meio de um mestre ou um amigo com mais experiência de si, "a relação com o outro aparece como uma dobra da relação consigo mesmo: cuidado de si como condição de cuidado dos outros, como um movimento de si para o outro" (Ortega, 1999, p. 129).

Além disso, é importante pontuar a temática do cuidado de si por meio de uma análise da parresía, ou seja, das práticas que dizem respeito a dizer a verdade sobre si mesmo (Foucault, 2011; Candiotto, 2008 ${ }^{29}$. Assim, o filósofo desenvolve um trabalho acerca das práticas de subjetivação do

28 Em teorias acerca do conceito de reconhecimento (Honneth, 2003; Safatle, 2015), a noção de predicados é utilizada pelo fato de denotar a seguinte entrada semântica: segundo a teoria política moderna, os predicados são considerados os privilégios que passam a ser vistos como propriedades, virtudes ou qualidades de indivíduos.

29 Conforme Foucault, "um dos significados originais da palavra grega parresía é o dizer tudo, mas na verdade ela é traduzida, com muito mais frequência, por fala franca, liberdade de palavra, etc. E enfim é uma técnica, é um procedimento: há pessoas que sabem se servir da parresía e outras que não sabem se servir da parresía. (...) E nessa cultura de si, nessa relação consigo, viu-se desenvolver toda uma técnica e toda uma arte que se aprendem e se exercem. Viu-se que essa arte de si necessita de uma relação com o outro. Em outras palavras: não se pode cuidar de si mesmo, se preocupar consigo mesmo sem ter relação 
sujeito ético, em que é necessário um "discurso verdadeiro para poder dar certa forma e determinado estilo à existência (...) a parresía socrática, em uma de suas vias, faz da vida 'objeto de elaboração e percepção’ estética” (Kohan, 2012, p. 114).

Nesse contexto, é possível pensar a formação dos sujeitos políticos através da prática de cuidado de si mesmos em políticas da amizade, pois o outro, em Foucault (1985), é fundamental na constituição da cultura de si. A amizade aparece como um ato de politização do espaço público, organiza-se pela livre escolha ou consoante movimentos de solidariedade (Ortega, 2002). Movimentos feministas, anti-racistas, LGBT ou anti-capitalistas, baseados na irmandade ou na fraternidade, podem colocar em xeque o funcionamento das instituições baseados na idealização da vida familiar e da lógica individualizante do capitalismo (Ortega, 2002). Há, portanto, uma transição da auto-constituição individual à subjetivação coletiva na forma de amizade, "o reconhecimento da esfera intersubjetiva revela-se como necessária na constituição do cuidado de si, a intersubjetividade aparece como resultado do cuidado de si, na forma do cuidado dos outros" (Ortega, 1999, p. 127 128).

Nesse sentido, a liberdade aparece como uma condição essencial para que os sujeitos políticos possam constituir a si mesmos, em processos de subjetivação compreendidos como práticas de si. Nesse aspecto, a liberdade se refere a uma problemática ética, de um ethos que dizia respeito a uma maneira de ser e de se conduzir: "como se pode praticar a liberdade? Pois o que é a ética senão a prática da liberdade, a prática refletida da liberdade?" (Foucault, 2010a, p. 267). Além disso, envolve uma dimensão política, pois esse tema tem a ver, inclusive, com a questão de não se permitir ser escravo de formas de governamentalidade em práticas de dominação de si e dos outros.

Foucault conduz a uma análise daquilo que fizemos para compreender aquilo que somos e sugerir possibilidades de transformação e invenção de nós mesmos. Há que conceber a vida como uma obra estética e trabalhar sobre si para que sejamos autoras/es de nossas suas próprias existências. O que compreende um ethos que diz respeito, invariavelmente, a uma relação com a humanidade do outro. Em outras palavras, o sujeito se forma a partir de uma produção viva de si ao entrar em contato com o outro, atribuindo um sentido as suas experiências. E, assim, a subjetivação política se realiza como processo por meio de práticas e finalizações de si, em que os sujeitos criam a si e uns aos outros numa relação de reconhecimento constitutiva.

A discussão crucial que se põe em análise é sobre a produção de subjetividades contemporâneas em que emergem novos sujeitos políticos. Envolve perceber que, por exemplo, tais sujeitos não se limitam somente a reivindicar lutas políticas visando a representação simbólica e a

com o outro. O dizer-a-verdade do outro, como elemento essencial do governo que ele exerce sobre nós, é uma das condições essenciais para que possamos formar a relação adequada conosco mesmos. (...) O ponto em que os sujeitos empreendem voluntariamente dizer-a-verdade, aceitando voluntária e explicitamente que esse dizer a verdade poderia lhes custar sua própria existência. Ou parresiastas são os que, no limite, aceitam morrer por ter dito a verdade. Ou, mais exatamente, os parresiastas são os que empreendem dizer a verdade a um preço não determinado" (Foucault, 2010c, p. 41 e 56). 
igualdade jurídica. As políticas de amizade aparecem, então, como uma viabilidade de legitimação das diferenças em processos de afirmação de si mesmos, para além de regras normativas e de gestões biopolíticas. De acordo com essa perspectiva reconhecimento, a resistência como uma subjetivação política se dá de outro modo: na invenção de si como sujeito, de uma ética e estética de si mediante um novo estilo de vida, em políticas da amizade.

Nesse sentido, a proposta é a de valorizar as formas pelos quais as pessoas trans podem se reconhecer como sujeitos de suas próprias vidas, como podem pensar-se, sentir-se, dar sentido a si e as suas experiências singulares. A estilística da amizade (Foucault, 1981; Ortega, 1999, 2002), em práticas de subjetivação de pessoas trans (Halberstam, 2005), é um necessário experimento social e político para reabitarmos o espaço público, de outro modo.

\subsection{Memória e o tempo dos processos de subjetivação}

A proposta de trabalhar com a noção de tempo é para considerar sua articulação com as práticas de subjetivação humanas, de acordo com o conceito de dobra explicado pelo diagrama de Foucault na abertura dessa seção. As ideias foram organizadas a partir da questão orientadora: qual o interesse em recuperar a concepção de memória relacionada ao conceito de tempo? Essa temática adveio da tentativa de ensaiar a análise das entrevistas, tendo em mente dois motivos principais, a saber: identificar a relação entre memória e narrativas e construir uma perspectiva sobre as práticas de subjetivação em experiências trans.

Por isso, nessa parte, se abordará as três sínteses do tempo trabalhadas por Deleuze (2006) em Diferença e Repetição: o hábito, a memória e a repetição enquanto eterno retorno (ao longo do texto esses processos serão melhor definidos). Tais sínteses do tempo foram pensadas pelo autor tendo como principais fontes de inspiração as obras de D. Hume, H. Bergson e F. Nietzsche, respectivamente.

A concepção de tempo em Deleuze é importante para o trabalho porque fornece indicadores sobre a memória enquanto construção do presente e criação do novo (Hur, 2009). Além disso, a memória é entendida como multiplicidade e evoca o caráter intersubjetivo e coletivo nos processos de produção de subjetividade. A partir desses entendimentos, pode-se observar que o ato de recordar é constituído por meio de uma múltipla conexão entre diferentes planos temporais e não se trata de algo determinado e fixo para ser acessado.

As novidades das teorizações de Deleuze (2006, 2013a) sobre a memória é que o passado não é decisivo para que o sujeito possa narrar sua história de vida ou para que possa justificar o seu atual posicionamento, pois o que ocorre é exatamente o inverso. O presente aparece como construtor das formações do passado, é a partir do presente que o sujeito seleciona as informações e inicia o seu relato. "O passado é invocado como justificativa para o atual posicionamento, ou seja, há uma modulação, uma plasticidade do passado, que é atualizado para defender as escolhas e 
posicionamentos do presente" (Hur, 2009, p. 206).

Durante o processo de trabalho da memória, pode-se observar, na construção do passado, o surgimento de acontecimentos que não ficam limitados a um passado ensimesmado, mas que constituem, ao mesmo tempo, o presente e o futuro. $\mathrm{O}$ sujeito organiza seus relatos a partir de uma coerência cronológica flexível, em que ele mesmo os seleciona e os organiza. Em A imagem-tempo, Deleuze (2013a) complementa: "as memórias e os sonhos ou até mesmo os mundos são circuitos relativos" (p. 104).

Por isso, coloca-se em análise uma concepção de memória que tem uma dinamicidade própria e apresenta um movimento de atualização do discurso e de produção do sujeito no seu presente. A vida é um filme interativo que sempre (re)compõe distintas imagens; as cenas que se repetem não remetem a um mesmo passado, mas aparecem como retorno de algo que já passa a assumir uma forma diferente (Deleuze, 2006). Então, o que "chama a atenção nessa abordagem é o fato de que a construção da memória produz tanto o presente quanto o passado. E o trabalho da memória, indubitavelmente, constrói acontecimentos e realidades sociais” (Hur, 2009, p. 206).

Há a possibilidade de transitar, deslocar-se em diferentes planos e dobras temporais, sendo que a memória se constrói de forma extensa e dispersa. "O tempo é a conexão entre dimensões heterogêneas e essas dimensões são concorrentes"30 (Deleuze, 2013a, p. 101). Tempo e memória trazem indicadores de processos de produção da subjetividade e assumem características fluidas e múltiplas (Hur, 2013).

Duff (2010) propõe que uma perspectiva do desenvolvimento deleuziana pode ser útil para analisar pesquisas diferentes daqueles modelos tradicionais de investigações (Morss, 2002). O filósofo evoca um olhar sobre a experiência humana em que o sujeito é posicionado num contexto.

Esse empreendimento parte de uma premissa epistemológica nomeada por Deleuze como empirismo transcendental (Deleuze, 2012). O autor elege esses termos de modo paradoxal, empirismo e transcendência, e o toma como ponto de partida de suas elaborações, segundo o qual situa sua filosofia no plano de imanência. Este plano não diz respeito a um sujeito e objeto prévios, tal como são concebidos pela filosofia da transcendência. Trata-se de um plano geográfico, que segue um eixo horizontal, onde se dão as conexões entre elementos e há a desconstrução de uma verdade prévia e essencializada. Assim, revelam o caráter descontínuo e acidental dos acontecimentos.

O campo do empirismo transcendental de Deleuze sugere a existência de agências entre sujeito e mundo, pois o sujeito é atravessado por diferentes planos temporais que o tornam protagonista de uma experiência múltipla. A sua filosofia rejeita o sujeito como uma categoria a priori e defende que a experiência do sujeito não é dada de antemão. Por isso, Deleuze (2012) acredita ter se deparado com o cerne do empirismo na questão da subjetividade. Segundo essas afirmações,

30 Existem segundo graus que se repetem entre o atual e o virtual. Para Deleuze, o atual é sempre objetivo e virtual é subjetivo. 
o conhecimento passa a se originar dos afetos ${ }^{31}$ do ser humano no campo empírico que organizam a experiência a partir de vários agenciamentos.

Essa é a contribuição que Deleuze fornece no intuito de pensar a subjetividade. Não se pode tratá-la a partir de um sujeito genérico e universal, pois existem, na verdade, subjetividades empíricas e sujeitos que constituem a sua experiência a partir de variadas interações em contextos concretos. É uma concepção não substancializada da subjetividade, pois diz respeito a um processo constante de invenção de si: "o sujeito se define por e como um movimento, um movimento de desenvolverse a si mesmo" (Deleuze, 2012, p. 99). O autor sugere um entendimento sobre a experiência não a partir do sujeito, mas a produção do sujeito a partir de sua experiência (Rodrigues, 2009).

Consequentemente, o sujeito não é um dado - um objeto passivo - e nem o desenvolvimento de si é linear. Desse modo, é produzido como criação que se conduz no tempo a partir das condições e dos afetos situados no campo experiencial, portanto, não pode ser concebido como um ser atemporal e imutável.

Deleuze $(2006 ; 2012)$ parte da filosofia de Hume para conceber a sua primeira síntese do tempo: o presente. Para o autor, é por meio da permanente aquisição de hábitos que a experiência se constitui, o hábito se opera por repetição de atividades e de costumes e se situa sempre no presente, ainda é motor de constituição dos organismos de acordo com o funcionamento de suas funções vitais $^{32}$ : “o hábito é a raiz constitutiva do sujeito e, em sua raiz, o sujeito é a síntese do tempo, a síntese do presente e do passado em vista do porvir" (Deleuze, 2012, p. 109).

Se Deleuze, a partir da filosofia de Hume, considera que todos os processos do presente envolvem contrações é porque a síntese passiva do tempo é contraída como hábito e constituem um presente vivido pelo sujeito. Sob o comportamento do hábito, Deleuze unifica o biológico e o psíquico, desenvolvendo a ideia de síntese passiva que dizem respeito as funções fisiológicas e psicológicas do organismo (David-Ménard, 2014). Trata-se de um processo de individuação biopsíquica.

31 "Afeto" é um conceito trabalhado por Spinoza e Deleuze. Para o primeiro, o "afeto" designa a maneira pela qual somos afetados, o que pode implicar ou no aumento ou na diminuição da nossa vontade de agir. Posteriormente, Deleuze indica com Spinoza que um sujeito é concebido pelos afetos de que é capaz; a singularidade da experiência é assim vista pois cada sujeito afeta e é afetado pelos outros corpos de maneira diferente. Portanto, os "afetos" não são sentimentos, mas designa uma mudança de devires "que transbordam aquele que passa por eles (tornando-se outro)" (Deleuze, 2010, p. 171). Segundo Deleuze, no interior dos conceitos filosóficos ou artísticos existem duas dimensões importantes, as dos afetos e dos perceptos. Estes não são vistos como percepções, são, por sua vez, "pacotes de sensações e de relações". Assim, "o afecto, o percepto e o conceito são três potências inseparáveis, potências que vão da arte à filosofia e vice-versa" (Deleuze, 2010, p. 171).

32 Se tomarmos o significado de "hábito" do dicionário, podemos perceber mais claramente o que Deleuze quer dizer. Conforme o dicionário de sinônimos online - https://www.sinonimos.com.br/habito/ - (retirado em 20 de dez. 2016), dentro dos quatro sentidos possíveis, existem dois que interessam para o contexto: prática habitual (costume, prática, rotina, convenção) e constituição de um organismo (constituição, aspecto, aparência, disposição, modo, jeito). Neste último sentido, pode-se aproximar a ideia de hábito ao que acontece nos estágios pré-individuais (de pré-individuação biopsíquica): há, no início, forças produtoras da gênese do indivíduo, tal como pontuado por Simondon. 
Todo organismo é, em seus elementos receptivos e perceptivos, mas também em suas vísceras, uma soma de contrações, de retenções e de esperas. Ao nível dessa sensibilidade vital primária, o presente vivido já constitui no tempo um passado e um futuro. Esse futuro aparece na necessidade como forma orgânica de espera; o passado da retenção aparece na hereditariedade celular (Deleuze, 2006, p. 115).

A contração significa que, nos processos de individuação biopsíquica, a formação do sujeito em sínteses orgânicas envolve uma passividade. Por outro lado, o conceito também expressa que o presente é contraído porque a sua existência é reduzida ao instante, que coexiste a outro instante. Assim, tanto o hábito como o presente são vistos como retraídos ou curtos, pois deriva "da ação instantânea que se compõe com outra para formar um elemento da repetição" (Deleuze, 2006, p. 116). O hábito opera segundo repetições que contém diferenças em si (Deleuze, 2006).

David-Ménard (2014), em Deleuze e a psicanálise, coloca que "o hábito tem por efeito a instauração do princípio do prazer" (p. 83). Nas discussões com a obra de Freud, o filósofo situa a síntese do hábito como constituição do presente e faz do prazer um princípio. Diferente da teoria freudiana, em que vivemos a repetição de um prazer obtido anteriormente ou a ser obtido, Deleuze afirma que "mais do que com o prazer, o hábito tem relação com a necessidade como espera, teimosia ou obstinação. Há, portanto, nesse primeiro registro do tempo, um futuro e um passado relativos ao presente" (David-Ménard, 2014, p. 83).

O sujeito permanece no tempo como duração a partir de uma sequência de técnicas de constituições de si mesmo. Logo, a ideia de hábito diz respeito à própria possibilidade de autoinvenção do sujeito: é em sua experiência empírica no tempo que ele/a se constrói pela incessante produção de si, é, ainda, pela contemplação de si mesmo visto como outro que se pode estabelecer os processos de subjetivação. "Sob o eu que age há pequenos eus que contemplam e que tornam possíveis a ação e o sujeito ativo. Não dizemos 'eu' a não ser por estas mil testemunhas que contemplam em nós; é sempre um terceiro que diz eu" (Deleuze, 2006, p. 118).

A primeira síntese do tempo advém do presente no tempo. Só o presente é a forma de expressão do tempo. A partir de uma síntese intratemporal, o presente constitui o passado e o futuro como as suas dimensões. Trata-se de um presente co-extensivo ao devir temporal. Assim, "basta fazer com que a contemplação se aplique sobre o infinito da sucessão de instantes (...) um organismo dispõe de uma duração de presente, de diversas durações de presente, segundo o alcance natural de almas contemplativas" (Deleuze, 2006, p. 120). Nesse sentido, a primeira síntese do tempo é originária e constitui o tempo como presente, é por onde se origina e se constitui. Há como consequência uma outra modalidade de tempo pelo qual se opera, trata-se da memória como segunda síntese do tempo: "o que faz com que o presente passe e se aproprie de outro elemento, o fundamento do tempo passa a ser a memória" (Deleuze, 2006, p. 123-124).

A memória, como uma síntese ativa que se deriva do hábito, constitui o passado. Num primeiro momento, pode-se dizer que o passado se apresenta entre dois presentes: um que já se foi e 
outro que está em relação ao qual é passado. O passado como reprodução da memória faz a mediação dos presentes - um antigo e outro atual (Deleuze, 2006), "reprodução do antigo presente e reflexão do atual" (p.125). A memória compõe a coexistência de planos temporais diferentes ${ }^{33}$ e, assim, o fluxo temporal adquire certo grau de estratificação e de circulação. Quando presente e passado coexistem entre si, pode-se dizer que há a inauguração da memória.

Existe na segunda síntese uma diferença em relação à primeira: o passado e o futuro deixam de ser dimensões do presente, assim, o presente e o futuro passam a ser contidos no passado em forma de memória. Esta "congrega uma multiplicidade de planos e dobras" (Hur, 2009, p. 218), as dobras significam uma reduplicação dos elementos do tempo (presente, passado e futuro), que se atualizam de forma multidimensional sobre a narrativa de sujeitos. Deleuze (2006) discute sobre o tempo como duração a partir da perspectiva de Bergson (2011), sendo que não há mais uma relação de sucessão e nem de continuidade entre passado e presente.

Em Matéria e Memória, Bergson (2011) sugere a existência de uma síntese transcendental de um passado puro, permitindo a Deleuze pensar os paradoxos constitutivos desse passado. $\mathrm{O}$ primeiro paradoxo diz respeito à contemporaneidade do passado em relação ao presente que se foi. Presente e passado passam, então, a ser contemporâneos e como consequência a memória adquire um caráter múltiplo: “o presente só é o grau mais contraído do passado com que ele coexiste se o passado coexistir primeiramente consigo mesmo numa infinidade de níveis. Consideremos o que se chama repetição numa vida" (Deleuze, 2006, p. 128).

Daí deriva o segundo paradoxo, que é o da coexistência, em que cada atual presente passa a ser o passado em seu caráter mais contraído: o passado inteiro estabelece uma relação de coexistência “com o novo presente em relação ao qual ele é agora passado (...) em vez de ser uma dimensão do tempo, o passado é a síntese do tempo inteiro, de que o futuro e o presente são apenas dimensões" (Deleuze, 2006, p.126).

O terceiro paradoxo é o da pré-existência que se complementa nos outros dois, há um elemento puro do passado que é pré-existente ao presente. É um passado que jamais é representado pelo presente antigo e atual. O passado puro se desdobra em sua forma de representação: "a síntese passiva transcendental diz respeito a este passado puro do triplo ponto de vista da contemporaneidade, da coexistência e da preexistência" (p. 127). Por sua vez, a síntese ativa, é a representação do tempo presente antigo e atual. Como passado transcendental, ele é anterior ao presente, mas é a condição fundamental para a passagem dos presentes (Pelbart, 2007).

A partir de duas coordenadas Deleuze pode contrapor uma memória concebida como síntese passiva, sub-representativa, transcendental, involuntária, à memória voluntária entendida como síntese ativa, representativa, vitória empírica sobre o esquecimento. A síntese passiva não vence o esquecimento, mas penetra no seu elemento. Não se representa o passado na forma de um antigo presente, mas mergulha no em-si do passado, que jamais foi presente -

33 Ou seja, a memória se relaciona ao presente e pode evocar passados próximos e, ao mesmo tempo, distantes do seu presente. Por exemplo, durante uma narrativa, há a possibilidade de lembrar de eventos de um passado ligado à infância que remete a outro passado mais próximo de suas vivências na vida adulta. 
o imemorial que precede qualquer presente, que lhe serve de fundamento, de condição. É nesse passado que constitui o objeto maior da faculdade da memória, onde ela encontra seu limite, isto é, sua potência, e que só ela pode atingir (...). O passado em-si não pode apresentar-se como objeto empírico de uma memória, na forma de uma lembrança, presente antigo, mas apenas como o imemorial, imemorável, o ser do passado, objeto da memória quando ela vai ao seu limite (Pélbart, 2007, p. 126-127)

É possível retirar uma lição dos paradoxos constitutivos do tempo: o passado não pode ser definido somente como um instante preso a um momento que já passou e não se origina apenas do presente. No próprio passado, segundo Deleuze, o imemorial e imemorável contém em si os conceitos de eternidade e imortalidade. É pela narrativa de um tempo imemorável que a experiência humana evoca o seu limite. Por outro lado, o passado é heterogêneo e diz respeito às várias expressões do tempo. Para Bergson (2011), o passado assume uma conotação especial e identifica a nós mesmos como protagonistas de nossas histórias singulares. "Somos nosso passado apenas porque todas as nossas experiências se produzem em nós de duas maneiras: como presentes que absorvem nossa atenção e nossas ações de um lado e como virtualidades que nos constituem sem que tenhamos que nos dar conta" (David-Ménard, 2014, p. 84). Nesse sentido, o passado é atual porque se mantém vivo no presente e dá as nossas vidas presentes um tom especial, embora ele seja somente o que nos remete a "nós mesmos" (David-Ménard, 2014).

A atividade da segunda síntese do tempo confere aos nossos presentes uma tonalidade singular. Na medida em que o passado faz parte de todas as nossas experiências, as mesmas são produzidas "como presentes que absorvem (consomem) nossa atenção e nossas ações, de um lado, e como virtualidades que nos constituem (...) as nossas experiências novas vem dos passados condensados, densos, consistentes (sic) (...) que nos permite reconhecer os presentes a partir de um análogo já encontrado" (David-Ménard, 2014, p. 84).

Bergson define a duração pela virtualidade e pela sincronia de tempos heterogêneos; se refere, então, a simultaneidade de múltiplos e diferentes planos temporais. Tal afirmação diz respeito à coexistência da lembrança e da percepção: é durante a experiência do sujeito com o dado perceptivo que a recordação é evocada. O próprio Bergson (2011) traz um exemplo emblemático da obra de Proust. Este escritor conferiu ao paladar e ao olfato a função de "convocar o passado" e elaborou também o conceito de transformação das próprias lembranças em percepções. Trata-se de um recurso utilizado em sua obra Em busca do tempo perdido que inspirou Bergson meditar sobre o conceito de "duração".

A duração, que é uma sucessão puramente interna a si mesma, opera de forma múltipla, pois se divide em um fluxo de diferenciação através de um processo pelo qual o tempo se difere de si. Ao se atualizar em cada etapa, a duração produz um efeito em que seus elementos continuam presentes mas mudam de natureza. Nesse sentido, "a duração é o virtual à medida que, no movimento de sua atualização, que se faz por diferenciação, se atualiza por linhas divergentes. Ir do virtual à sua atualização significa habitar uma dimensão puramente temporal" (Fornazari, 2004, p. 34). 
Nesse sentido, Bergson (2011) considera que rememorar funciona através de processos e de duração. Tanto a primeira síntese como a segunda apresentam modos diferentes de produzir subjetividades. No entanto, a duração não pode assumir um campo pré-reflexivo e pré-representativo (o presente) pois só existe subjetivada por meio da síntese ativa do tempo que é a memória (Pélbart, 2007). O presente não tem duração, mas os acontecimentos sim. Ou seja, tanto a memória quanto a duração são tempos subjetivados e ambas se compõem de acordo com planos virtuais simultâneos.

A memória se manifesta como uma multiplicidade com distintos níveis de contração e distensão ${ }^{34}$, em que aparecem lembranças e perceptos coexistentes. A memória é mobilidade e inventividade, não se traduz pela remissão do presente ao passado, o que ocorre é o oposto, uma passagem do passado ao presente.

Como já foi mencionado, passado e presente fabricam-se mutuamente. Assim, prefere-se avaliar a constituição de subjetividades como produção, “em que há a coexistência virtual de planos temporais e experienciais. Alguns mais estratificados, mais instituídos e organizados e outros mais fluídos, desorganizados, então, preferimos pensar a maquinaria do psiquismo como uma multiplicidade de coexistência virtual” (Hur, 2009, p. 219).

A aposta de Deleuze (2006) foi a de conceituar a ideia de uma estrutura aberta e, por isso, constrói um estruturalismo composto por multiplicidades. O pós-estruturalismo une a ideia de estrutura com a de excesso, heterogeneidade e agenciamento. Logo, com base na teoria de Deleuze, os processos de investigação se baseiam na produção de sentidos que operam de modo mais flexíveis e não estáticos (esse ponto será recolocado no método e durante as análises). Na sua filosofia, o autor pensa por imagens e elabora um sistema em rede que se organiza a partir de diversos blocos e linhas, que assumem posições diferentes ou ainda coexistentes (Hur, 2009). As imagens de um mosaico ou de um caleidoscópio poderiam ser evocadas para descrever a operação dos conceitos de tempo e subjetividade.

David-Ménard (2014) elabora sobre o caráter e o efeito eróticos na produção da memória, o que envolve uma ligação entre a reminiscência e o desejo. Aqui Deleuze se aproxima da psicanálise (David-Ménard, 2014). Em Diferença e Repetição, o autor esclarece que os conceitos de fixação, regressão, trauma e cena original são tratados de forma equivocada, visto que pressupõem dois tempos: um original e o outro derivado, em que há a repetição do mesmo, sob um disfarce. "É em relação ao objeto virtual ilocalizável, ele mesmo sendo o disfarce, que os presentes, tanto o atual quanto o passado, constituem duas séries coexistentes, numa repetição tal que nenhuma delas pode

34 Deleuze usa as expressões "contração" e "distensão" relativas ao tempo para caracterizar a qualidade dos processos temporais. A passagem de um tempo ao outro (em diferentes planos) pode ser mais rápida, curta ou simultânea ou ainda mais longa. A contração, portanto, refere-se ao caráter aglutinado (combinado) ou agrupado dos planos temporais; a distensão, por sua vez, diz respeito ao aumento do comprimento ou da duração dos planos entre si, produz um efeito que se prolonga. "O tempo vivido não tem a regularidade dos relógios, pois parece arrastar-se em situações de dor e sofrimento, enquanto aparentemente acelera-se quando a felicidade ou o prazer estão ou são presentes" (Gurgel, 2012, p. 74). 
ser dita original ou derivada" (Pelbart, 2007, p. 128).

Nessa relação, o efeito erótico da memória se dá porque seu objeto de reminiscência não é o antigo presente, mas se trata de uma matéria virtual e imemorial de um passado puro. Deleuze exalta as relações entre Eros e Mnemósina ao trabalhar a sua teoria sobre o passado. A principal característica dessa conexão é sua mobilidade errática, pois não tem relação com o presente antigo e o atual.

É a partir desse ponto que se desdobra a terceira síntese do tempo: os objetos de desejo são virtuais e não coincide com algo presente e real. Isso quer dizer que o presente não permite a repetição de um tempo anterior, "a psicanálise está errada ao deixar que se acredite no caráter primeiro dos amores infantis. A teoria freudiana da posterioridade da instauração bifásica dos objetos sexuais, como uma realização do passado, como se este fosse uma fonte" (David-Ménard, 2014, p. 88). O amor não advém de uma atualização de um passado remoto, o amor que remete à mãe, mas assume uma relação com um objeto virtual e imemorável. Há um caráter de originalidade e ineditismo a cada experiência amorosa (Deleuze, 2006; Pelbart, 2007).

David-Ménard (2014) complementa: “não é porque a ideia de sexualidade infantil seja um erro, mas porque uma filosofia do tempo como repetição exige que se coloque radicalmente em causa uma unificação de uma história" (p. 89). O sujeito, capturado por um desejo e em busca de um tempo perdido, tenta descobrir nas virtualidades de um passado remoto um elemento secreto para dar sentido ao seu destino. No entanto, a busca em dar sentido ao segredo que move sua história e a sua singularidade é compreendida retrospectivamente como um efeito de ótica: “"o em-si' do passado e a repetição na reminiscência seriam uma espécie de 'efeito', como um efeito ótico, ou antes o efeito erótico da própria memória” (David-Ménard, 2014, p. 90)

Na primeira síntese do tempo o hábito mobiliza a força de constituição do sujeito e é a fundação do tempo, na segunda síntese há a articulação entre os presentes e os passados, em que aparece a inauguração da memória como fundamento do tempo. Na terceira síntese, instaura-se uma brecha para o acontecimento e a indeterminação e a memória aparece como geradora do futuro. Assim, Deleuze elabora uma terceira síntese segundo a concepção nietzschiana de eterno retorno para representar a repetição num modelo espiralado de tempo. Todas as sínteses do tempo são baseadas na ideia de que tudo é repetição, seja no caso do hábito em que há a repetição de instantes e de funções biopsíquicas; no caso da memória, há a repetição de um conjunto de planos temporais virtuais e coexistentes e, por fim, na terceira, há a repetição do futuro como eterno retorno (Deleuze, 2006; Hur, 2009). É a repetição da diferença a que chamou de futuro:

Na verdade, é o passado, como também o presente, que é repetição em si mesmo, de dois modos diferentes que se repetem um no outro. Não há fatos de repetição na história, mas a repetição é a condição histórica sob a qual alguma coisa de novo é efetivamente produzida (Deleuze, 2006, p. 138).

Nesse sentido, a terceira síntese do tempo promove um rompimento e uma fragmentação em 
direção ao futuro, bem como projeta uma abertura para o acaso, o indeterminado e o acontecimento. Apesar de haver uma linearidade do tempo na terceira síntese, que não é simples e se apresenta como uma imagem do novo, do começo e da criação. A linearidade implacável da terceira dimensão da repetição do tempo renuncia o presente inaugurado por um passado puro e evoca a ilusão de um horizonte originário. É a própria representação do que Deleuze chama de devir como afirmação de um futuro a ser produzido e criado constantemente. Para Hur (2013), nesse contexto, a memória passa a se caracterizar por ser geradora de futuro: "podemos entender, então, que a repetição do eterno retorno é a produção de uma memória ligada ao novo, à diferença e a criação" (p. 188).

Na terceira síntese, o tempo aparece em sua forma pura e vazia, pois se trata do "fundamento ultrapassado em direção a um sem-fundo, a-fundamento universal que gira em si mesmo e só faz retornar o por-vir" (Deleuze, 2006, p. 139). O presente e o passado passam a ser dimensões do futuro. É assim que a terceira síntese age no intuito de estabelecer uma organização, um processo em série e a finalização do tempo. "O eterno retorno só afeta o novo, isto é, o que é produzido sob a condição de insuficiência e por intermédio da metamorfose" (Deleuze, 2006, p. 138). Nas três sínteses do tempo, elaboradas por Deleuze, existem elementos que permitem observar o processo de constituição da subjetividade quando aborda o hábito formado no presente, a memória como multiplicidade e a memória geradora de um futuro.

Essa incursão teórica sobre o conceito de memória e tempo em Deleuze (2006; 2013a) permite situar um ponto importante para este texto, que será utilizado para as análises das entrevistas. Trata-se de avaliar a experiência do sujeito no presente a partir de suas experimentações no mundo. Assim, a memória passa a ser vista como uma forma de organização subjetiva múltipla que desperta para novas possibilidades de subjetivações. Do mesmo modo, a intenção é relativizar o conceito de história como evolução e de vida como desenvolvimento linear de um específico indivíduo, "o homem". O ato de lembrar de si e do outro passa a não ser visto apenas como um processo individual e abstrato, se produz, porém, em um plano comum e coletivo.

\subsection{Gênero e as práticas de subjetivação}

Para complementar o eixo teórico na tessitura dessa cartografia, utiliza-se a perspectiva de gênero de J. Butler (1997; 2001; 2013a; 2013b; Salih, 2012) para refletir sobre como o gênero participa e se articula com os processos de constituição da subjetividade. Considerada representante do pensamento queer, a teoria de Butler está em consonância com as ideias de Foucault e Deleuze, uma vez que também se apoia no pensamento francês contemporâneo. A autora traz uma problematização acerca da metafísica da substância quando questiona o gênero como uma categoria fixa e a priori. Essa crítica é central na elaboração de suas teses sobre a performatividade que será explicada mais adiante.

Em A vida psíquica do poder, Butler (1997) toma a perspectiva de Foucault como peça 
fundamental de suas análises. Assim, considera a subjetivação como uma instância material da constituição de sujeitos segundo uma forma paradoxal de poder. É inegável que se trata do diagrama da subjetivação descrito pelo conceito topológico de dobra no início dessa cartografia. Butler, então, entende que o poder forma o sujeito, também possibilita e condiciona a sua existência. Por isso, o poder não é algo que apenas lutamos ou resistimos, mas é o meio pelo qual dependemos para a nossa preservação enquanto seres humanos. A subjetivação consiste na dependência de um discurso que estamos enredados e não escolhemos fabricar, ao mesmo tempo inicia e sustenta a produção de nossas agências. Nesse sentido, "a subjetivação significa o processo de se tornar subordinado pelo poder, assim como o processo pelo qual nos tornamos sujeitos (...) o sujeito é iniciado através de uma submissão primária ao poder" (Butler, 1997, p. 2).

A partir dessas elaborações, Butler questiona qual é a forma psíquica que o poder apresenta. Por isso justifica a importância de pensar numa teoria do poder junto a uma teoria sobre o psiquismo: o poder aparece primeiramente como externo, pressiona o sujeito pela subordinação, para depois assumir uma forma psíquica que constitui a auto-identidade do sujeito. A consciência passa a ser compreendida como uma operação psíquica reflexiva advinda de normas regulatórias, estabelece-se pelos efeitos de poder num trabalho psíquico e social (Bulter, 1997). A formação do sujeito se dá a partir de uma configuração de poder tomada pela figura do retorno, que volta sobre si mesmo. É uma modalidade de poder que retorna sobre si, sendo o sujeito efeito do poder em processo de recuo. Por sua vez, a figura do retorno opera a partir da explicação: trata-se do modo pelo qual o ser humano é produzido quando assume a função topológica de sujeito. O dilema topológico, então, determina como o poder produz seu sujeito e como o poder (re)cria a si mesmo.

É nesse sentido que a subjetivação é inaugurada de um paradoxo situado topologicamente. Um paradoxo da subjetivação ligado ao problema da referencialidade, pode-se exemplificar tal afirmação da seguinte forma: mediante o ato de se nomear ou de ser citado pelo outro, pois não há possibilidade de se referir aquilo que ainda não tem existência. Nesse sentido, a subordinação do sujeito acontece através da linguagem, que é a instância primeira de inauguração e representação do sujeito a partir do domínio do simbólico: "o sujeito é uma ocasião linguística para a conquista individual e uma reprodução de inteligibilidade, a condição linguística para sua existência e agência" (Butler, 1997, p. 4)

O processo de sujeição se refere a uma pré-condição para que vários agenciamentos de poder produzam o sujeito e garantam a sua existência. Nesse sentido, o poder passa a ser concebido como prioridade do sujeito em sua eficácia instrumental, sendo marcado pelo problema da agência. É possível dizer que o sujeito é a condição e o impasse dessa agência. Para Butler (1997), essa perspectiva do poder diz respeito ao que é trabalhado em nós mesmos, constituindo o sentido da agência mediante a atualização constante de nossos atos e a expansão de seus efeitos.

A importância de Butler para esse trabalho é fundamental, pois a autora situa o conceito foucaultiano de subjetivação no âmbito da vida psíquica: "nós recusamos o dualismo ontológico que 
posiciona a separação do político e do psíquico, isso parece crucial para oferecer um relato crítico da subjetivação psíquica em termos de regulação e produção de efeitos de poder" (Butler, 1997, p. 29). Se existem formas regulatórias que proporcionam a emergência do sujeito e se sua constituição segue alguns critérios do poder através da incorporação das normas, a teoria de formação do sujeito deve levar em conta um importante processo de interiorização. Numa topografia, a norma se torna psíquica. O processo de interiorização revela uma diferença existente entre a vida interior e a exterior, entre o psíquico e o social e a internalização psíquica das normas mediante um procedimento ativo e não mecânico.

A forma da norma funcionar no psiquismo conduz a uma regulação do poder, cuja proposta é fornecer uma operação estratégica no meio social. Em seu modo de funcionamento psíquico, a norma não apenas situa o poder social, mas tem um modo diferente de operação em condições específicas, podendo situar, inclusive, as de vulnerabilidade. Algumas formas de categorizações sociais podem estabelecer uma vulnerabilidade do sujeito no âmbito da linguagem a partir de mudanças históricas e psíquicas. Segundo Butler (1997), a normatividade psíquica e linguística tem a prioridade de realizar modalidades de restrições no social: "o sujeito devém das condições de poder que o precede. Nesse sentido, a operação psíquica da norma é derivada, embora não mecanicamente ou predicativamente, de práticas sociais" (p. 29).

A partir dessas elaborações, pode-se dizer que a subjetivação é um efeito paradoxal dos regimes de poder. Ao derivar tanto das condições de existência quanto da possibilidade de reconhecimento social, requer uma formação que mantém o sujeito numa ambivalência. A subjetivação psíquica evidencia como o poder social modela a subjetividade ao mesmo tempo que limita a sua sociabilidade. Por isso as análises sobre o processo de subjetivação precisam seguir uma direção dupla, das condições de formação do sujeito e do retorno contra as condições para que o sujeito possa emergir. Ou seja, é o desenvolvimento do sujeito pelas práticas de resistência. (Butler, 1997).

Essas formulações sobre o conceito de subjetivação, segundo uma perspectiva foucaultiana, permite a Butler pensar acerca dos regimes de poder reguladores das normas de gênero (Butler, 2013a). Então, é possível afirmar que as práticas de constituição do sujeito são engendradas por normas regulatórias de gênero. No livro Problemas de gênero - feminismo e subversão da identidade, a autora realiza um debate sobre como a categoria de gênero foi sendo compreendida pela teoria feminista contemporânea, em que a noção de gênero passa a ser entendida como uma interpretação cultural do sexo. Ao ser visto como algo que é construído socialmente, passa a ser utilizado como uma categoria instrumental e política. O problema dessa perspectiva é vê-lo a partir de um determinismo social que exclui a possibilidade de agência e transformação (Butler, 2013a).

É importante explicitar os vários sentidos dados ao conceito de gênero na teoria social e nas vertentes feministas. Quando o gênero é entendido como um índice de diferenciação biológica, linguística e cultural pode representar como significado um corpo que já foi diferenciado 
sexualmente, mas esse sentido precisa ser lido de modo relacional. Algumas autoras feministas, como Scott (1995), sugerem o gênero como uma relação ou um conjunto de relações. Há outras, dentre as quais Beauvoir (2009), que afirmam ser o feminino o gênero marcado, pois o masculino é o universal, portador de uma individualidade abstrata e desencarnada. Irigaray (2009) elabora a impossibilidade de o "sexo" ser simbolizado como uno e a noção de "homem" representar o todo, por isso sobrepesa com base em sua ética da diferença sexual ${ }^{35}$, que, para ela, constitui uma importante fonte de análise e coloca visibilidade no modo como o ocidente tendeu à reprodução dos corpos em determinados sistemas de inteligibilidade.

Butler (2013a) discorre acerca dessas assertivas para confirmar o seguinte: "o sexo que não é uno propicia um ponto de partida para a crítica das representações ocidentais hegemônicas e da metafísica da substância que estrutura a própria noção de sujeito" (p. 29). Ao longo da modernidade ocidental foi se construindo um discurso sobre o sexo e a sexualidade advindos de uma ciência sexual. Foucault nomeia esse processo com a inauguração do dispositivo da sexualidade, "o sexo se torna um lugar de poder, ele se torna um objeto de discursos legais e reguladores; ele se torna aquilo que o poder em seus vários discursos e instituições cultiva na imagem de sua própria construção normativa" (Butler, 2013b, p. 96) Nesse sentido, Butler (1988) entende que a categoria de sexo e de gênero nem sempre se constituiu da mesma maneira em diferentes períodos históricos. Quando Foucault usa o termo sexo ao conduzir a história da sexualidade, o que chama de sexo-rei devido ao seu caráter altamente produtivo e regulatório, Butler prefere usar o termo gênero para falar de algo muito semelhante.

Assim, ela desfaz a distinção que separa as noções de sexo e gênero para defender a tese de que não há sexo que não seja já e, desde sempre, gênero. Em outras palavras, a categoria sexo faz parte de uma demarcação discursiva apoiada em práticas sociais. Não existe possibilidade de existência humana que não seja social, significa que não existe corpo natural (sexo biológico) préexistente a sua inscrição cultural. A autora feminista, então, salienta:

O 'sexo' não apenas funciona como norma, mas é parte de uma prática regulatória que produz os corpos que governa (...). Ele não é um simples fato ou condição de um corpo, mas um processo pelo qual as normas regulatórias materializam o 'sexo' e produzem essa materialização através de uma reiteração forçada destas normas (...) as normas regulatórias

35 A ética da diferença sexual consiste em interrogar o lugar das categorias mulheres e homens. Para Salomon (2010), uma leitura queer dos trabalhos de Irigaray implica em colocar que os corpos, as fronteiras entre as categorias de gênero, e as relações da diferença sexual não precisam excluir a "diferença sexualmente" ou "os sexos vistos de forma diferenciada". Ou seja, a ética da diferença sexual permite colocar as relações humanas fora do escopo das estritamente cisheteronormativas. Assim, as configurações corporais ou as identificações não podem ser entendidas como estritamente masculinas ou femininas. Por exemplo, Irigay situa a experiência da mulher na história: "o feminino permanece num lugar separado de seu próprio lugar, ela é ou incessantemente torna-se o lugar de um outro que não separa o homem de si mesmo. Sem conhecer como funciona esse processo e é um ser ausente de desejo, a mulher é ameaçada pelo o que a falta: seu próprio lugar. Ela deveria 're-envelopar' a si como si mesma, ao menos duplamente" (Irigaray, 1993, p. 10-11). Salomon, por isso, questiona como poderíamos traçar uma cartografia dos corpos a partir da diferença sexual entre mulheres, entre homens, ou o que há entre o somático e o psíquico, que não seja em um lugar estável e facilmente identificável. 
do 'sexo' trabalham de uma forma performativa para construir a materialidade dos corpos e, mais especificamente, para materializar o sexo do corpo, para materializar a diferença sexual a serviço da consolidação do imperativo heterossexual (Butler, 2001, p. 153-154).

Segundo Butler (2001), é a cultura heterossexual que mantem o argumento da distinção essencialista entre sexo e gênero. No nosso cotidiano vivemos nossas vidas sem notarmos que somos regulados por normas generificadas, pois são concebidas pela nossa cultura a partir de regimes discursivos de verdade; do mesmo modo, a linearidade gênero-sexo-sexualidade é entendida como o padrão de "normalidade", também denominado heteronormatividade.

Assim, a autora compreende que as normas de gênero são constituídas socialmente e mantém a exclusão de sujeitos que não se conformam ao sistema de uma "heterossexualidade compulsória" (Butler, 2013a; 2013b). Pode-se dizer que as subjetividades normativas emergiram na modernidade através da matriz heterossexual por meio das relações de poder (Arán, 2006). A heteronormatividade passou a ser um padrão de sexualidade que tem regulado hegemonicamente a produção dos processos de subjetivação nas sociedades ocidentais.

Wittig (1992), outra representante do pensamento queer, também tematiza sobre a categoria de sexo quando problematiza a concepção de "pensamento hetero", dizendo que é "a opressão que cria o sexo e não o contrário" (Wittig, 1992, p. 2). Como consequência dessa afirmativa não há, para a autora, "distinção entre sexo e gênero, a própria categoria de 'sexo' traz marcas de gênero, é politicamente investida, naturalizada e não natural” (Butler, 2013b, p. 164). O "pensamento hetero" tende a demarcar nítidas fronteiras entre subjetividades; por sua vez, a sociedade "hetero" é marcada pela hegemonia de um grupo social que domina as diversas formas de singularidades. Só há o outro como diferente e abjeto, porque há a produção de uma identidade normalizadora socialmente constituída. A sua tarefa é desconstruir a operação discursiva sobre o sexo e subverter a gramática que estabelece o gênero como o "sexo fictício". Assim, a heterossexualidade se estabelece a partir de um discurso pautado por um regime político e social que oprime as mulheres, as lésbicas, os gays e os/as transexuais.

É nesse sentido que Wittig entende a categoria de "sexo" como uma abstração forjada para imprimir uma forma de inteligibilidade social, produzindo uma realidade reificada. Apesar de o sexo ser visto como um dado empírico que descreve a nossa experiência corpórea, Wittig afirma que esse dado perceptivo tem sido inserido de forma violenta em nossas vidas e é, muitas vezes, tratado de forma natural. Essa forma de violência advém de um regime de heterossexualidade compulsória que opera segundo uma matriz de reprodução sexual. Tanto o masculino como o feminino só existem devido a um sistema heterossexual. Comentando Wittig, Butler afirma que “'sexo' é efeito de realidade de um processo violento, dissimulado por esse mesmo efeito. Em outras palavras, o sexo impõe uma unidade artificial a um conjunto de atributos de outro modo descontínuo" (Butler, 2013b, p. 163).

Nessa mesma linha de raciocínio, discorre sobre o problema de definir as posições de sujeito 
com base em categorias binárias de sexo, gênero e sexualidade. De outro modo, a categoria de sexo está ancorada na concepção de performatividade de gênero, em que há uma vinculação direta entre a materialidade do corpo e a forma de como o sujeito realiza as suas práticas sexuais. Portanto, o gênero é performativamente constituído, "o gênero não é algo que somos, é algo que fazemos, um ato, ou mais precisamente, uma sequência de atos, um verbo em vez de um substantivo, um 'fazer' em vez de um 'ser'” (Salih, 2012, p. 89).

A partir dessa ideia, pode-se compreender que as subjetividades são performativamente constituídas. Dessa forma, Butler afirma que o gênero demonstra ser performativo, quer dizer, constituinte da identidade que pretende ser ou que simula ser. Nesse sentido, o gênero é sempre um fazer, embora não um fazer por um sujeito que possa dizer que preexista ao feito: "não há identidade de gênero por trás das expressões de gênero; a identidade é performativamente constituída pelas próprias 'expressões' que supostamente são seus resultados" (Butler, 2013b, p. 48).

O ponto central é que o gênero se constitui a partir das normas e os seres humanos atuam segundo essas normatizações. Tais normas constitutivas do gênero poderão ser repetidas ou citadas de tal modo que passam a reproduzir a normatividade genérica, ou ainda, de tal maneira que possam questionar e subverter a normativa em questão. A todo momento se atualiza as normas de gênero a partir das relações sociais e para atuar não precisamos de um personagem ou um papel pré-definidos. O gênero é efeito de uma repetição de normas e se constitui por meio de atos, de hábitos, de uma materialidade dos nossos corpos em interação.

É importante considerar que Butler faz uma distinção entre performance e performatividade, argumentando que, enquanto a performance supõe um sujeito preexistente, a performatividade contesta a própria noção de um sujeito a priori e substantivo. Ela usa o conceito de performatividade da teoria linguística de Austin (1975). Assim, para a autora, as enunciações performativas possibilitam a criação de realidades de sexo e gênero tal como os compreendemos.

O gênero é um ato que faz existir aquilo que nomeia, pode fabricar um homem "masculino" ou uma mulher "feminina". As identidades de gênero são constituídas pela linguagem, o que significa que não há identidade de gênero que a preceda. Não é uma identidade que faz o discurso, mas precisamente o contrário, o discurso ou a linguagem é que fazem o gênero. Não existe um "eu" fora da linguagem, uma vez que a constituição da subjetividade é uma prática simbólica e os sujeitos culturalmente inteligíveis são efeitos e não causas de discursos. É nesse sentido que o gênero é performativo. As subjetividades, antes de ser escolhida por um agente individual, precedem e constituem esses agentes ou sujeitos. Pode-se usar a analogia do guarda-roupas ao argumentar que o gênero é performativamente constituído, do mesmo modo que a escolha de roupas de alguém é delimitada, talvez até pré-determinada pela sociedade, economia e contexto no qual alguém está situado.

Sexo e gênero são construções culturais "imaginárias" que demarcam e definem o corpo. Por isso, o gênero é sempre um fazer, não se trata de um fazer realizado por um sujeito preexistente 
ao feito. Existem três exemplos relevantes que podem ilustrar essas teses de Butler. Primeiro, através do anúncio sobre se um feto será "uma menina" ou "um menino"; a constatação realizada por um especialista diante da tela de um aparelho de ultrassonografia inicia um processo de produção de um corpo definido como feminino ou masculino. Este ato de fala tem um caráter performativo e estabelece uma série de atos que vai constituir uma pessoa com sexo e gênero determinados. Segundo, o caso de um/a hermafrodita em trabalho produzido por Foucault retrata a incapacidade de Herculin Barbin em se adequar os binarismos de gênero, mostrando a instabilidade das categorias de sexo e gênero como substâncias fixas. Assim, a confusão entre os gêneros pode mostrar o seu caráter ilusório. Terceiro, as normas de gênero quando vistas em diferentes contextos exibe, de forma contundente, o seu modo construído ou fabricado. A drag queen, ou o drag king, se aproxima do seu objeto de imitação ao mesmo tempo que o expõe e o critica. E demonstra, mediante o exagero, que as normas de gênero possuem um caráter artificial.

Tais exemplos são vistos como as várias possibilidades de agências da constituição de gênero, tanto pela subversão como pelo reforçamento das hierarquias e das diferenças sexuais. Nesse contexto, é entendido como um conjunto de normas que se efetiva apenas em função de sua permanente atualização, por isso se encontra aberto a um processo de ressignificação. Por sua vez, a ressignificação das normas de gênero dependerá da composição de protótipos que possibilitam a sua transformação. Dessa forma, a significação ou ressignificação das normas está relacionado às tramas do poder sob os quais o gênero do sujeito é constituído (Butler, 1997). Com efeito, essa perspectiva sobre o poder torna-se fundamental, pois diz respeito a como a reprodução do reconhecimento social está ligada à imposição de uma hierarquia. A contestação desse regime político-social pode ser castigada, seja pela discriminação, exclusão ou até mesmo pela morte. A normativa de gênero impõe um sistema de reconhecimento que pode vulnerabilizar, de diferentes modos, os sujeitos que dela participam.

No entanto, há a possibilidade de criar no interior do poder normativo uma performatividade como movimento de resistência. Ao se habilitar algumas mudanças é possível questionar a agência política atual sem enclausurar os sujeitos num sistema de inteligibilidade. As atuais políticas sexuais no contexto das democracias estão vinculadas à regulação da vida sexual tal como Foucault colocou em A história da sexualidade. Pode-se questionar se é possível pensar tais políticas mediante o gerenciamento da diversidade sem privar os sujeitos de suas liberdades sexuais no âmbito dos direitos civis. Da mesma forma que implica em alguns avanços no campo dos direitos, pode impor certas limitações nos ideais de justiça e liberdade. As ideias butlerianas abrem espaço para dizer que as normas sexuais e de gênero podem ser questionadas ou interpretadas de diferentes formas, por isso ressignificar as normas cria brechas para a sua subversão. Só há possibilidade de mudança política e social por meio da ressignificação das normas (Sabsay, 2014).

A emergência dos movimentos de gênero e dos movimentos queer tem alcançado alguns direitos sexuais em países latino-americanos, europeus e nos Estados Unidos. É inegável que o 
horizonte de conquistas ainda é muito longo. Para contextualizar, tais movimentos estavam se consolidando quando Butler elaborava a suas teses sobre performatividade de gênero. Nesse momento, ser queer tinha por função questionar a vigilância constante sobre a sexualidade das pessoas e se opor aos complexos regimes de poder produzidos pela heteronormatividade. A novidade foi promover uma subversão das normas psíquicas (heteronormativas) que pudesse conferir inteligibilidade e organizar, de outra forma, o meio social (Sabsay, 2014).

Nesse sentido, a perspectiva queer de Butler busca contestar e desconstruir os binarismos dessas categorias e anuncia, com base na concepção de performatividade, a instabilidade e a indeterminação das identidades. Pode-se dizer que as experiências trans subvertem a gramática normativa do sistema sexo-gênero, visto que pressupõe a não conformidade entre os termos, produzindo outros efeitos de gênero e de sujeito. Esse modo de constituição da subjetividade, como sugere o próprio movimento instável do queer, perturba aqueles/as que estão preocupados/as em conservar as oposições entre macho/fêmea, masculino/feminino, homo/hetero e assim sucessivamente.

Pode-se observar esse processo de normalização ou subversão das normas de gênero tanto do ponto de vista micropolítico quanto macropolítico. Micropolítico no âmbito da agência de poder que acontece entre nossas relações e do nível macropolítico no das agências de poder que se dá entre movimentos sociais e Estado, por exemplo. O contexto político da contemporaneidade tem se salientado por novas modalidades “de regulação sexual e pela produção de outros modos de exclusão que se somam às formas tradicionais, tornando mais complexo, deste modo, o cenário de lutas e das reivindicações direcionadas à liberdade e à justiça genérico-sexuais" (Sabsay, 2014, p. 30). Tem-se uma série de acontecimentos em na sociedade brasileira contemporânea, como o embate entre o fundamentalismo religioso e os movimentos feministas e LGBT. O momento da história em que vivemos é privilegiado para discutirmos sobre essas análises da Butler e de Foucault, em que há o acirramento dos jogos de disputa para a regulação das normas de gênero.

A perspectiva de Butler desconstrói o determinismo social e cultural em torno da categoria de gênero, questionando visões e referências teóricas que se reduzem às armadilhas das identidades. Nesse sentido, a sua teoria sobre a performatividade tem por finalidade mostrar a existência de possibilidades para uma ação política transformadora, em que se pode ressignificar as normas de gênero mediante novas agências. Como consequência, é possível estabelecer o reconhecimento social e legal por meio da constituição de novos direitos.

Isso porque o giro butleriano se dá no âmbito do poder como uma instância psíquica reguladora e, assim, situa-se no âmbito dos processos de subjetivação, em que pode haver a emergência de novas subjetividades. As normas de gênero são psiquicamente incorporadas e se constituem pela ambivalência, que é explorada pelo próprio poder regulatório, entre a sujeição e a prioridade de existência social. É possível dizer, então, que as subjetividades são produzidas a partir de agências e operações estratégicas entre formas mútuas de regulação tanto do poder quanto do 
psiquismo. Essa assertiva mostra a complexidade dos processos envolvidos na formação de sujeitos.

Nessa seção, buscou-se realizar um percurso teórico e metodológico com base numa cartografia. A perspectiva de M. Foucault, G. Deleuze e J. Butler fornecem instrumentos conceituais para pensar como as subjetividades têm sido produzidas na contemporaneidade. Em especial, situase no âmbito de subjetividades de pessoas trans. Tais teóricos e teórica foram aproximados como panorama no intuito de teorizar acerca das dinâmicas psicológicas envolvidas nas práticas de subjetivação, como a autorreflexividade, a memória e a autorregulação psíquica.

A noção de dobra indica um modo de funcionamento da subjetivação humana por uma duplicidade e uma ambivalência que lhe é constituinte: o sujeito não é idêntico a si mesmo, é assujeitado aos poderes e aos discursos, mas, ao mesmo tempo, produz-se a partir de resistências aos dispositivos de poder. A partir desse movimento, passa a reivindicar um lugar e um nome que lhe são próprios.

Do desafio de conectar as categorias de subjetivação com as de gênero e tempo numa imagem topológica mediante o recurso do diagrama, que, num primeiro momento, aparece sob a imagem da dobra, surge a ideia de fazer com que tais conceitos funcionem como dispositivos da pesquisa, pois apresentam um modo de operacionalidade dentro da tese. Ou seja, tal teorização será um recurso importante durante as análises, pois fazem operar os procedimentos de investigação e a tessitura vertical desta tese.

É importante assinalar que a cartografia trabalha com imagens e movimentos situados num espaço e tempo específicos. Nesse sentido, trata-se de um exercício de localização que conecta formas heterogêneas num plano de imanência. Este plano de organização móvel mostra como se dá a produção dos sujeitos e objetos da realidade social, "longe de limitar seu olhar à realidade fixa, tal como propõe a abordagem da representação, a cartografia visa a ampliação de nossa concepção de mundo para incluir o plano movente da realidade das coisas" (Escóssia \& Tedesco, 2009, p. 92).

O próximo momento dessa cartografia situa a formação do problema acerca dos processos de subjetivação no âmbito de uma experiência singular. A produção de novas subjetividades está vinculada com o modo pelo qual o dispositivo da transexualidade (Bento, 2006, Lima, 2010) também se reproduz nas práticas de constituição de sujeitos trans. A ideia é coordenar um percurso sobre como subjetividades transgêneras e cisgêneras têm sido produzidas por um conjunto de técnicas, práticas e dispositivos. A construção do saber acerca da transexualidade está imerso numa série de aparatos técnico-discursivos que visam ditar uma verdade sobre quem é o sujeito e como deveria viver. O que se coloca em evidência é o papel da Psicologia e de suas práticas no arranjo dos regimes de saber-poder em questão.

Nesse sentido, o dispositivo da transexualidade conforma, apresenta ou ainda fabrica determinadas práticas de produção de sujeitos. É preciso levar em consideração que tal dispositivo, como um regime de verdade ou ainda de poder-saber, subjuga-os ao mesmo tempo que possibilita a constituição de práticas de resistência, tal como diz Foucault (2010a; 2011) e Butler (1997). No atual 
espaço-tempo, tem emergido como uma nova forma de constituição subjetiva de um "si" singular e coletivo, sendo que existem várias formas de ser e se dizer trans. Logo, é importante questionar qualquer tipo de universalização, pois se trata de uma experiência singular, coletiva e múltipla. 


\section{PRODUÇÃO DE NOVAS SUBJETIVIDADES}

Nessa seção conduz-se um percurso sobre a produção de novas subjetividades no contexto contemporâneo. O manejo teórico-conceitual realizado anteriormente é considerado instrumental para a construção dos dispositivos, pois faz operar o campo problemático ${ }^{36}$ (Fonseca \& Costa, 2013) desta cartografia. A teorização sobre como as novas subjetividades têm sido constituídas será trabalhada no âmbito de experiências transgêneras e transexuais, trata-se de investigar as produções de si como trans.

É preciso dizer que os conteúdos da subjetividade dependem de uma relação entre vários elementos (Guattari, 1996) discursivos e não-discursivos. Nesse sentido, a constituição da categoria transexual, em especial, está hegemonicamente ligada ao desenvolvimento indissociável da oferta de tecnologias médicas, sobretudo hormonais e cirúrgicas.

Rose (2011) explicita que a experiência humana é fabricada, intrisecamente, pelos agenciamentos sócio-técnicos historicamente localizados. Há um campo da subjetividade composto por saberes e por elementos materiais, sociais, políticos, linguísticos e tecnológicos. Esse campo constitui tanto sujeitos quanto objetos técnicos, por isso ambos emergem dessa relação heterogênea inserida numa rede de conexões, que está constantemente em processo de transformação e agenciamento (Kastrup, 2007).

A psicologia, por sua vez, é uma tecnologia intelectual (Rose, 2011) ou uma expertise capaz de tornar inteligível esse campo de problematização da subjetividade. Inspirado pelos trabalhos de Foucault, Rose (2011) ainda pontua que o desenvolvimento "do saber psi tem estado conectado, de forma significativa, com transformações nas formas de subjetividade" (p. 24). As concepções que, em geral, tecemos sobre as pessoas e faz com que possamos compreendê-las estão vinculadas à "correlação entre campos de saber, tipos de normatividade e formas de subjetividade em uma cultura particular" (Foucault, 1984, p. 3).

Essa assertiva foucaultiana elucida acerca dos modos em que os processos de regulação social e psíquica produzem regimes inteligíveis de subjetivação. Portanto, trata-se de algumas indicações sobre como os sujeitos trans têm sido regulados e regulam a si mesmos no intercurso dos jogos de verdades. É nesse sentido que Castel (2001) trata o "fenômeno transexual” como um indicador das transformações históricas ocorridas na ciência e das modificações culturais e políticas da identidade sexual do século XX. Ou seja, experiências trans são vistas como produções localizadas em determinados regimes de saber-poder e, a partir de um processo ativo e dialógico ${ }^{37}$,

36 Como pontuado anteriormente, o delineamento dos objetos de pesquisa na cartografia está circunscrito no modo de construção do problema de pesquisa. Compreende-se os termos a partir de sua dependência intrínseca a fim de produzir consistência entre as variáveis processuais constituintes da investigação.

37 Dialogia é um termo utilizado por Bakhtin para descrever as relações entre as produções inerentes à vida com as trocas simbólicas, compostas pelos sistemas de signos. As relações dialógicas não são reduzidas as lógicas dialéticas nem as estritamente linguísticas, mas se situa no âmbito do jogo polifônico. O outro é 
tem imprimido modalidades de intervenção na realidade social. Essa experiência é produzida num dado contexto e, da mesma forma, interfere nos modos contemporâneos de subjetivação.

Num primeiro momento, a transgeneridade e a transexualidade podem ser consideradas experiências bastante complexas. Arán (2006) pontua que essa experiência pode ser "caracterizada pelo sentimento intenso de não pertencimento ao sexo anatômico, sem a manifestação de distúrbios delirantes e sem bases orgânicas" (p. 50). Não se trata, portanto, de alucinações de metamorfose sexual que ocorrem na esquizofrenia e, além disso, descarta-se o diagnóstico de intersexo ou qualquer outro distúrbio endócrino (Castel, 2001).

$\mathrm{O}$ contato com a experiência trans possibilita o acesso a uma realidade desconhecida para a maioria das pessoas. Dessa forma, "a identidade trans provoca incômodo, estranhamento e incompreensão" (Zambrano, 2011) e, na maioria das vezes, tenta-se enquadrá-la em qualquer uma das categorias inteligíveis da sexualidade humana. Para o senso comum a concepção de gênero equivale à noção de sexo ou sexualidade (Butler, 1993; 2001). Na nossa cultura contemporânea ocidentalizada, muitas vezes, o que se coloca em questão não é a identidade de gênero, mas sim a orientação sexual e todas as repercussões relativas ao papel da heteronormatividade e do binarismo como dinâmicas de regulação sociais dominantes.

Segundo Stryker (2006), autora norte-americana de referência internacional no âmbito dos "Estudos Transgêneros" (Transgender Studies), a palavra "transgênero" foi utilizada pela primeira vez por volta da década de 80 por Virginia Prince (1980), uma ativista trans que se tornou responsável pela publicação da Revista comercial Travestia, desde a década de 1960, e que visava propagar, mediante seus relatos autobiográficos, a liberdade de expressões de gênero. Prince utilizou o termo para se referir a pessoas como ela que se encontravam dentro do espectro entre "transvestite" (um termo cunhado em 1910 pelo médico Magnus Hirschelf) e "transexual" (uma expressão popularizada na década de 1950 por Harry Benjamin).

Em 1992, a expressão "transgênero" começou a ser empregada conforme o sentido que lhe é atribuída atualmente. Na década de 90 , os movimentos sociais queers e trans começaram a ter proeminência nos Estados Unidos, por isso o termo passou a ser utilizado em textos manifestos Transgender liberation: a movement whose time has come - por Leslie Feinberg (1996), outra ativista trans também conhecida pela publicação Transgender Warriors: Making History from Joan of Arc to Dennis Rodman. Neste livro, a autora define o conceito de "transgênero" para evocar seu sentido como um adjetivo e não como um substantivo. Isto porque "o termo define uma aliança política entre os sujeitos que têm sido marginalizados pelas diferenças marcadas pelas normas de gênero e que lutam juntos por justiça social, política e econômica” (Stryker, 2006, p. 4, tradução livre).

Um outro marco do movimento trans nos EUA é a publicação do Manifesto Posttransexual

central para a produção de novas subjetividades e possibilita que das contradições (estas apresentam diferentes vetores de forças) emerjam a constituição de novos sentidos. 
(Stone, 2006). Na tentativa de ocupar um espaço como um sujeito no escopo dos discursos tradicionais sobre gênero, Sandy Stone pontua que a sua tarefa é a de "desconstrução". Das experiências trans vistas como produções textuais pode-se "encontrar o potencial para mapear o corpo simbolizado no discurso de gênero convencional e, assim, é possível interrompê-lo, aproveitando as dissonâncias criadas por tal justaposição para fragmentar e reconstituir os elementos do gênero em geometrias novas e inesperadas" (Stone, 1993/2006, p. 232, tradução livre).

Nesse sentido, "Estudos Transgêneros" é um projeto crítico relativamente novo que tem tomado corpo nas duas últimas décadas e está diretamente relacionado com as emergentes "condições pós-modernas", por isso tem se pautado por uma produção teórica e metodológica inovadora (Stryker, 2006; 2008). No Brasil, tem sido constituído, no contexto acadêmico, por ativistas transfeministas $^{38}$ (Jesus, 2014, 2016a; 2016b; Jesus et al, 2014; Vergueiro, 2015) e por pesquisadoras/es interessadas/os em fomentar discussões de ordem teórico-prática sobre a transexualidade (Arán, 2006; Bento, 2006; Lionço, 2006; 2009; Teixeira, 2009; Lima, 2010; Ávila, 2014; Porchat, 2014). Além disso, é importante ressaltar o papel que o ativismo LBGT e, particularmente, o transexual e o travesti têm assumido nos últimos anos, como protagonistas de suas próprias experiências, na luta pela promoção e igualdade de seus direitos.

Stryker (2006) defende que “os 'Estudos Transgêneros', através da subjugação de formas previamente marginalizadas de conhecimento sobre a subjetividade de gênero e a incorporação sexuada, prometem uma intervenção crítica radical" (p. 12). No livro Em defesa da sociedade, Foucault (2010d) pontua que os conhecimentos que foram historicamente subjugados estão inseridos em um conjunto de pensamentos funcionais e sistemáticos, todavia, foram encobertos e a arguição crítica se tornou preparada e pôde divulgar a sua existência no âmbito do saber científico. Assim, quando Foucault fala sobre como determinados conhecimentos foram subjugados, aponta uma saída por meio da partilha política da comunidade envolvida. Este raciocínio é um ponto de partida metodológico e é essencial para avaliar os efeitos da relação entre as novas subjetividades produzidas e os conhecimentos gerados a partir de suas práticas sociais.

Os "Estudos transgêneros" se posicionam na tentativa de articular produções teóricas inovadoras com um trabalho de pesquisa com arquivos históricos (as primeiras publicações científicas sobre as experiências trans). Na metade do século passado, uma literatura especializada sobre a "disforia de gênero" agregou as investigações de Harry Benjamin e seus colegas John Money e Robert Stoller, o que resultou, em 1980, na homologação de uma categoria clínica definida como psicopatologia então validada pela APA (2002; Stryker, 2006; 2008).

A fim de situar como o dispositivo da transexualidade foi sendo produzido pelo discurso científico, realiza-se uma breve cronologia do seu desenvolvimento. As primeiras referências

38 Existem várias publicações veiculadas na internet como blogs e perfis de facebook, como exemplo, cito: https://feminismotrans.wordpress.com/tag/transfeminismo/. Retirado em 06 de janeiro de 2017. 
encontradas na literatura sobre a experiência trans podem ser situadas no final do século XIX e início do século XX, no momento em que a sexologia e a psiquiatria começam a realizar uma semiologia das identidades sexuais. Krafft-Ebing, um proeminente sexólogo alemão, relata o primeiro caso de "transexualismo" em 1893, enquanto Magnus Hirschfeld, em 1910, utiliza pela primeira vez o termo para descrever o que nomeou como "transexualismo psíquico" (Leite Júnior, 2008; Murta, 2014).

O endocrinologista Harry Benjamin desenvolveu inicialmente o que podemos chamar de dispositivo da transexualidade devido ao fato de ter descrito as experiências trans como uma síndrome. Seus trabalhos se tornaram uma das principais referências na construção das nosografias psiquiátricas (Bento, 2006; Arán, Murta \& Lionço, 2009). Nesse sentido, tem sido diagnosticada segundo as nomenclaturas "transexualismo", "transtorno de identidade de gênero" ou "disforia de gênero" pelo discurso médico desde o século XX. É inegável a importância do desenvolvimento da ciência médico-endocrinológica para a produção do que se chama "fenômeno transexual" (Castel, 2001; Murta, 2014). Trata-se de referências cientificas que, a partir da produção de uma etiologia somática da síndrome, tinha por objetivo realizar uma prática terapêutica hormonal.

É possível dizer que se passa a assumir a si como "transexual” quando se toma conhecimento da cirurgia de mudança de sexo a fim de se adequar aos padrões de normalidade. Trata-se de um discurso que constrói um "transexual oficial" a partir do dispositivo da transexualidade (Bento, 2006; Lima, 2010). Zambrano (2003; 2011) afirma que "as premissas que orientam o discurso médico quanto ao diagnóstico e à realização de transgenitalização são heteronormativos" (p. 104), ou ainda cisnormativos, pois partem do pressuposto de que existem dois sexos e dois gêneros equivalentes, que apresentam como orientação normal a heterossexual. E, assim, é necessário que haja uma concordância harmônica entre esses termos.

As experiências trans, todavia, estão fora das regras da cisheteronormatividade e os/as transexuais, por sua vez, "constroem uma história de vida adequada aos critérios diagnósticos de maneira a garantir a cirurgia, submetem-se ao discurso médico para garantir um direito (o acesso à cirurgia) que deveria ser seu, sem questionamento" (Zambrano, 2011, p. 104).

Conforme a Portaria 1482/97 do Conselho Federal de Medicina (CFM), é necessário a interferência do profissional de psicologia e apresentação do relatório psicológico que apresente um parecer técnico especializado e ateste a condição psicológica da transexualidade. Hoje tornou-se importante discutir a formação deste profissional nos cursos de graduação e pós-graduação devido às atuais demandas no que tange as relações de gênero e sexualidade com os processos de subjetivação humanos.

Ainda que a categorização diagnóstica seja útil para a conquista de direitos à assistência à saúde, como a realização de cirurgia pelo serviço público de saúde, ela não deve ser a meta final do atendimento psicológico, visto que a categoria "transexualismo" ou todas as variações patologizadoras obscurece uma importante questão a ser considerada: "a transfobia inerente ao diagnóstico" (Murta, 2007, p. 85; Jesus, 2014). Salienta-se, portanto, que há uma tendência que se 
refere à transfobia de um modo geral presente em toda a sociedade brasileira e abre um debate absolutamente contemporâneo sobre a constituição de direitos à cidadania para as pessoas trans, em geral.

A principal ideia, para esse capítulo, é problematizar a complexidade de elementos envolvidos na produção de subjetividades, bem como dos dispositivos envolvidos em sua constituição. Há de se discutir o papel da Psicologia, enquanto ciência e prática social, para a promoção de saúde e cidadania das pessoas trans. Por isso, torna-se imprescindível questionar o modelo de diagnóstico psicopatológico (de TIG, "transexualismo" ou "disforia de gênero") que tem o intuito de conceder um parecer técnico favorável. Este se apoia, muitas vezes, na ideia de cura da experiência trans e se fundamentam institucionalmente na retificação de nome e de gênero nos registros civis e na cirurgia de redesignação sexual. Ou seja, a própria cirurgia é vista pelos saberes médicos e jurídicos, que forma o dispositivo da transexualidade, como uma possibilidade de cura da dissonância que há entre o corpo, a percepção psíquica sobre o corpo e a identidade de gênero (apresentação social de si como homens, mulheres ou variações).

Uma das possíveis formas é a revisão de critérios psicodiagnósticos normativos, uma vez que "transexualidade e travestilidade não constituem condição psicopatológica, ainda que não reproduzam a concepção normativa de que deve haver uma coerência entre sexo biológico/gênero/desejo sexual" (CFP, 2013, p. 2). Trata-se de não reforçar estereótipos de gênero e de sexualidade para não visar a normalização das práticas de constituição desses sujeitos, segundo o viés do binarismo de gênero, da cisheteronormatividade e da transfobia.

Os movimentos sociais para a despatologização das subjetividades trans (STP, 2012) inserem, nessa discussão, uma mudança de paradigmas no modo de conceber das expressões de gênero: "de um ponto de vista de transição de gênero como uma desordem mental ao reconhecimento dos seus direitos humanos e a expressão da diversidade sexual" (Suess, Espineira \& Walters, 2014, p. 74). Por isso, uma questão importante é debater a perspectiva de despatologização das subjetividades trans sem colocar em risco a assistência à saúde, em que se podem agravar as desigualdades sociais de acesso aos serviços médicos-jurídicos.

A ideia é conceber o direito à saúde e o direito à despatologização da experiência como dimensões fundamentais de direitos humanos, "a partir de estratégias que facilitem o acesso ao sistema de saúde para cuidados especiais à população trans dentro de uma perspectiva de despatologização" (Suess, Espineira \& Walters, 2014, p. 75). Na contemporaneidade, as experiências trans estão envolvidas em múltiplas composições e embates discursivos, sendo uma expressão provocativa das formas hegemônicas de subjetivação e da ordem social de gênero.

\subsection{O dispositivo da transexualidade e suas racionalidades}

A noção de dispositivo pode ser considerada um recurso transversal a essa cartografia, pois 
compõe conjuntos de elementos discursivos, que, uma vez conectados, exibem modos específicos de operacionalização. Trata-se de um aspecto inerente à própria pesquisa cartográfica. No mapa textual dessa tese, as coordenadas da investigação são traçadas por determinados dispositivos. Estes se configuram como mecanismos que possibilitam circunscrever a problematização central e se efetuam nos procedimentos da pesquisa, por isso conduzem à geração e ao desdobramento de determinados efeitos e resultados.

Pode-se dizer, dessa forma, que o dispositivo da transexualidade conduz a certos tipos de operações e de agências em que modos de subjetivação em experiências trans são produzidos. Assim, os dispositivos emergem de algumas dinâmicas de saber-poder instituídas, o saber surge como componente no exercício do poder e tem uma importância capital na forma como é exercido. É possível observar essa relação entre saber, poder e subjetividade pelo diagrama de Foucault (Deleuze, 2013) trabalhado no primeiro capítulo. Segundo Butler (1997), tal diagrama diz respeito à influência das dinâmicas de saber-poder exercidas sobre os processos de autorregulação psíquica e, portanto, das práticas de subjetivação.

Por meio da noção de dispositivo da sexualidade, Foucault (1988) explora o cenário de transformações ocorridas entre os séculos XVII a XIX em que o sexo passou a ter legitimidade científica na emergência e na constituição de uma scientia sexualis, passando a ser utilizado como um instrumento para a normalização e a regulação social no interior de espaços institucionais. Assim, a partir da consolidação do biopoder e do investimento cada vez maior sobre o corpo dos sujeitos, a sexualidade passou a ser, progressivamente, objeto de análise das relações de saberes e poderes. Tal contexto inaugura modalidades de "operações nos corpos das pessoas, sobre suas almas, sobre seu próprio pensamento, sobre sua própria conduta" (Foucault, 1993, p. 209), podendo ser elaboradas nas técnicas de si mediante operações sobre o próprio corpo e a própria subjetividade sob os regimes de saber/poder.

A transexualidade se desenvolve a partir desse dispositivo descrito por Foucault (1988), podendo ser situada num dado momento histórico (Bento, 2006; Lima, 2010). É possível dizer que ao longo do século XX, especificamente, após a década de 1950, foi se consolidando um conhecimento capaz de descrever e explicar as experiências trans sob a nomenclatura de transexualidade. Bento (2006) pontua que a pessoa transexual passa "a se constituir como um dispositivo específico, que se encontra em pleno período de operacionalização, com a organização crescente de comissões ou projetos vinculados a hospitais visando a 'tratar' os 'disfóricos de gênero"” (Bento, 2006, p. 128). O objetivo era a construção de um determinado dispositivo que apresentasse a verdadeira etiologia da transexualidade, sendo criados os sintomas e diagnósticos psiquiátricos específicos para essa experiência (Bento, 2006).

A construção do transtorno de identidade de gênero consolidado num F.8x no âmbito do Diagnóstico de Saúde Mental (DSM) é resultado de um complexo processo que envolve diferentes domínios de saberes e de relações de poder com a ideia da transexualidade (Lima, 
2010, p. 65).

Segundo Castel (2001), o conceito de identidade de gênero é anterior a nosografia diagnóstica que compõe a transexualidade como dispositivo e foi pensada pelo viés do behaviorismo endocrinológico. Essa vertente introduziu uma aceitação das teses sociológicas realizadas em meados da década de 40 sobre o conceito de identidade sexual. Ainda no século XIX, a endocrinologia já demonstrava resultados sobre o funcionamento dos hormônios sexuais e contribuiu para uma compreensão acerca do sexo biológico e das variações sexuais, sendo interpretadas como falhas do desenvolvimento sexual. Assim, os conceitos de sexo e de gênero foram diferenciados no intuito de construir uma patologia psiquiátrica, o gênero tornou-se "uma noção mais clara que a de sexo e consagrou o triunfo em psiquiatria de uma concepção sociológica particular da identidade" (Castel, 2001, p. 78).

Murta (2011) diz que a história científica e cultural do que se chamou de experiência da transexualidade está relacionada, principalmente, a duas situações: primeira, ao surgimento de uma leitura acerca das bases biológicas do sexo e do gênero e, segundo, ao desenvolvimento das tecnologias de mudança cirúrgica de sexo. "A partir da análise do avanço da tecnologia médica que, no século XX, viabilizou a relação de modificações corporais do sexo e a construção da categoria de gênero que fundamentou o diagnóstico de transtorno de identidade de gênero" (Murta, 2011, p.14$15)$.

Dessa forma, é importante pontuar como as categorias de sexo e de gênero têm sido compreendidas no interior do registro científico. Por exemplo, Stryker (2006) apresenta que um determinado paradigma científico tem imprimido uma escritura sobre o corpo dos sujeitos a partir da fundação de um "sexo" ideal. A consequência disso é a produção de regimes de verdade que visam representar uma realidade objetiva a partir do mapeamento de uma subjetividade particular. Logo, as práticas de subjetivações

das/os transexuais, das travestis e da inversão de gênero dos butches e dos queers trabalham para confundir as noções simplistas do determinismo material e do paradigma representacional em ciência (que são vistos de modo especular), em relação às questões de gênero. De outro modo, o "sexo", que quer se tornar outro, não é o fundamento do gênero, da mesma forma que uma maçã não é o fundamento de um reflexo de frutos vermelhos no espelho, o "sexo" é a fusão de elementos distintos, uma história que misturamos sobre o que o corpo significa, quais são as partes que mais importam e como elas se inscrevem em nossa consciência ou em nosso campo de visão. A ideia de "sexo" é construída para servir de fundação a um projeto e ocupa um espaço escavado por uma determinada construção epistemológica (Stryker, 2006, p. 10, tradução livre).

É possível observar um panorama de como houve as transformações conceituais dos termos sexo e gênero, no intuito de promover os procedimentos de mudanças corporais, por meio das teorizações acerca da transexualidade enquanto um dispositivo de saber-poder, tal como já salientaram Bento (2006) e Lima (2010). Dentro de um determinado paradigma, trata-se das 
elaborações de Krafft-Ebing (1893/2006), Hirschfeld (1910/2006), Cauldwell (1949/2006), Harry Benjamin (1966/1999; 2006), Money (1969) e Stoller (1982; 2006). Esses autores motivaram a circunscrição da transexualidade como uma patologia e de sua construção como nosografia psiquiátrica, deram origem ao conceito de "Transtorno de Identidade de Gênero", a partir de minuciosas descrições examinaram aspectos biológicos, sociais e psíquicos. Portanto, atuaram de modo "a fundamentar a discordância entre sexo e gênero e na proposição de modelos de trabalho para esses casos baseados na correlação de sexo" (Murta, 2014, p. 68)

Nesse sentido, o desenvolvimento das técnicas de modificações corporais devido aos hormônios e aos procedimentos bem-sucedidos das cirurgias plásticas contribuiu para a construção, a partir dos anos 50, do "transexualismo" (Castel, 2001). O conceito "disforia de gênero" foi elaborado por Norman Fisk em 1973 (Castel, 2001), segundo uma compreensão híbrida psiquiátricosociológica. Essa categoria visava responder às legislações jurídicas que exigiam a medicalização da redefinição do sexo. Consoante Castel (2001), "os avatares da disforia de gênero abriram em seguida um caminho nas nosografias oficiais (as versões sucessivas do DSM), no quadro global dos 'distúrbios da identidade de gênero"” (p. 90).

Assim, foi forjada pelo discurso médico como uma doença mental de identidade e enquadrada no DSM-III como "transexualismo". Enquanto este último manual foi publicado na década de 1980, em 1994 houve a substituição do termo "transexualismo" pelo "transtorno de identidade de gênero" indexado no DSM-IV (2002). No DSM-V voltou a ser classificado como "disforia de gênero", em que é destacada a seguinte consideração: "é importante notar que a não conformidade de gênero não é, em si, uma desordem mental. O elemento crítico de disforia de gênero é a presença de sofrimento clinicamente significativo associado à condição" (APA, 2013, p. 1). É importante considerar que "a disforia", como um conceito psicopatológico, apresenta a conotação de um mal-estar transitório, de origem vaga e é acompanhado de sentimentos de tristeza e angústia.

Nas últimas décadas, muito se discutiu sobre a necessidade de adequação das pessoas trans em relação ao corpo biológico que se sentem pertencer. Desse modo, o desejo de adaptação às normas de sexo e gênero produz uma determinada expressão de subjetividade às experiências trans. No entanto, o dispositivo da transexualidade estabelece nítida diferença entre sexo e gênero, sendo que a dissonância entre os termos designa um caráter psicopatológico.

Seguindo essa linha de raciocínio, médicos pensaram sobre os procedimentos de tratamento para essa condição por meio da cirurgia de redesignação sexual e, assim, foram institucionalizados espaços de assistência a pessoas trans. Trata-se da Fundação Harry Benjamin e da Fundação de Pesquisa Identidade de Gênero, que realizavam pesquisas científicas no intuito de estabelecer a etiologia da transexualidade e construir terapias adequadas à demanda. A partir de uma parceria entre Benjamin e Money foi iniciada, em 1966, no Hospital Johns Hopkins, a primeira clínica para a realização da cirurgia de redesignação sexual nos Estados Unidos (Bento, 2006; Lima, 2010; Murta, 2007; 2011). 
No Brasil, muitos programas de assistência a essa população específica foram regulamentados, inclusive o direito de fazer cirurgia de transgenitalização pelo SUS. O Conselho Federal de Medicina (CFM), mediante a já mencionada Resolução 1482/97, em novembro de 1997, realizou a aprovação das cirurgias de transgenitalização nos hospitais públicos universitários do Brasil. Posteriormente, a Resolução $n^{\circ}$ 1652/2002 revogou a anterior para regulamentar a organização da rede de assistência e normatizar os procedimentos de transgenitalização em hospitais públicos e privados ${ }^{39}$. Em seguida, foi publicada, em 2008, a Portaria 457 da Secretaria de Assistência à Saúde que estabelece diretrizes com o objetivo de promover o acesso assistencial com qualidade e equanimidade. De acordo com a referida Portaria, foram estipulados como Unidades de Atenção Especializada no processo transexualizador quatro hospitais universitários, Hospital de Clínicas de Porto Alegre (UFRGS), Hospital Universitário Pedro Ernesto (UERJ), Hospital das Clínicas da Faculdade de Medicina da USP e Hospital das Clínicas da Universidade Federal de Goiás (Teixeira, 2009; Lima, 2010; Murta, 2011).

A cirurgia de redesignação sexual passa a ser, então, legalizada no Brasil, mas como condição o CFM estipula que se torna necessário realizar uma avaliação criteriosa por uma equipe multidisciplinar de saúde composta endocrinologista, cirurgião/ã plástico/a, psiquiatra, psicólogo/a, enfermeiro/a e assistente social (Arán, Murta \& Lionço, 2009; Borba, 2014). Nos últimos anos, tem aumentado significativamente a demanda de assistência específica às pessoas transexuais (Murta, 2011). Consoante Murta (2011), esse fato tem mostrado tanto o processo de constituição de programas especializados a essa população como a exposição à vulnerabilidade no que se refere ao acesso à saúde. Do mesmo modo,

a reivindicação transexual desenvolveu-se numa dialética sutil entre a oferta tecnológica (a dos endocrinologistas e cirurgiões movidos pela compaixão, mas também preocupados em testar hipóteses sobre a natureza humana e suas determinações biológicas) e uma demanda de cuidados mais e mais estruturada por um discurso padronizado, oferecendo aos médicos a imagem exata do que eles esperavam de seus doentes (Castel, 2001, p. 78).

Segundo as diretrizes baseadas pelo Instituto Internacional de Disforia de Gênero Harry Benjamin, que orientam as normativas e portarias brasileiras, é necessário o acompanhamento psicológico por dois anos previamente às cirurgias de redesignação sexual. Dessa forma, antes dos procedimentos cirúrgicos, tornou-se obrigatório a apresentação do diagnóstico de "transexualismo" (F. 64), de acordo com o Código Internacional de Doenças (CID-10), de "transtorno de identidade

39 Segundo tal documento, o atendimento em serviços privados é legalizado somente para casos de mulheres transexuais, condicionando aos homens transexuais a falta de assistência à saúde em clínicas privadas, mas também em outras redes de assistência do SUS, devido ao caráter de pesquisa para transexuais masculinos. Vale ressaltar também que travestis não têm o mesmo acesso aos serviços públicos de saúde. Segundo Lionço (2009) existe um caráter ambivalente e parcial dessa regulamentação, pois as normativas brasileiras do processo transexualizador têm velado, no âmbito do diagnóstico de Transtorno de Identidade de Gênero, os preconceitos de identidade de gênero e orientação sexual existentes na sociedade brasileira e no acesso aos serviços de saúde. 
de gênero" (TIG) segundo o DSM-IV e hoje tem se utilizado a nomenclatura "disforia de gênero" (DSM-V). Para Murta (2011; 2014), o acesso de pessoas trans aos serviços públicos de saúde tem sido condicionado, infelizmente, ao diagnóstico psicopatológico pela equipe técnica.

Por conseguinte, para usufruir dos serviços de atenção especializada do Programa Assistencial é necessário atender aos critérios estabelecidos pela descrição nosográfica e comprovar ser um “transexual verdadeiro" (Benjamin, 1966/1999). Então, é realizada uma avaliação inicial para saber se o paciente pode ou não entrar no projeto e, depois de incorporado ao mesmo, é reavaliado durante todo o procedimento terapêutico. Usualmente, o processo de acompanhamento é realizado de acordo com as etapas a seguir: avaliação psiquiátrica para a confirmação do diagnóstico; psicoterapia individual ou de grupo; terapia hormonal; avaliação genética e, por fim, a cirurgia de redesignação sexual (Arán, Murta \& Lionço, 2009). Todos esses procedimentos estão condicionados para o atendimento na assistência de saúde pública no Brasil e em iniciativas privadas tem sido considerado apenas o relatório psicológico.

Assim, a/o psicóloga/o ou psiquiatra deveria apresentar um laudo com tal diagnóstico como parecer favorável à realização da cirurgia. Vale ressaltar que tanto "transexualismo" quanto "transtorno de identidade de gênero" são conceitos eminentemente médicos e não conseguem dar conta da problemática das construções discursivas das expressões de gênero sob o viés da normatividade cis e heterossexual. Por isso, estabelece um olhar estigmatizante sobre as pessoas trans ao enfatizar o que é patológico ou anormal, criando, ainda, possibilidades de mais discriminações. Dessa forma, são considerados, dentre os indivíduos que pertencem aos grupos de lésbicas, gays, bissexuais e transgêneros/as (LGBT), os que mais sofrem preconceitos e são estigmatizados.

Durante a sua pesquisa de campo com o público transexual, Bento (2006) encontrou na fala de seus entrevistados a interseccionalidade de processos de exclusão: "pode-se notar que há um viés de classe social constante: muitos/as (sic) são oriundos de camadas sociais excluídas. O fato de vivenciarem a experiência transexual, ou seja, de estarem fora das normas de gênero, torna essas pessoas duplamente excluídas" (Bento, 2006, p. 61). Tais pessoas são excluídas de um conjunto de instituições e de espaços sociais, mantendo-se permanentemente marginalizadas.

A discussão proposta permite contextualizar a Psicologia como um saber também conformador do dispositivo da transexualidade (Bento, 2006; Lima, 2010; Borba, 2014), visto que a relação característica entre a subjetividade e a sexualidade, tratada pela ciência psicológica, revelase crucial na sua constituição. De fato, o dispositivo da transexualidade se delimita por um conjunto de saberes e domínios interdisciplinares: a Medicina, em especial a Psiquiatria e Endocrinologia, a Sexologia, a Psicologia e a Psicanálise (Lima, 2010). A socióloga brasileira Berenice Bento, em sua tese $A$ (re)invenção do corpo: sexualidade e gênero na experiência transexual, foi a primeira autora a cunhar a expressão. Posteriormente, a antropóloga Fátima Lima dos Santos buscou traçar a genealogia do termo em sua tese de doutoramento (Oliveira, 2013; Borba, 2014a). 
O dispositivo da transexualidade precisa ser compreendido dentro da racionalidade de um projeto científico que visou medicalizar e enquadrar tanto o corpo individual quanto o social. Segundo as indicações deixadas por Foucault (1988), a sua gênese pode ser localizada nos séculos XVIII e XIX com o desdobramento da chamada scientia sexualis. Importante ressaltar que "o processo de medicalização da sexualidade, principalmente, a separação dos comportamentos perversos dos patológicos e dos normais, foi o movimento que redefiniu as classificações e as condutas no que se refere aos comportamentos sexuais" (Lima, 2010, p. 61).

Pode-se citar como exemplo as elaborações do médico Krafft-Ebing (1897/2006), que, no final do século XIX, classificou e descreveu em sua obra Psychopathia sexualis às patologias relacionadas sexualidade, e do sexólogo Hirschfeld (1910/2006) em The Transvestites - the erotic drive to cross-dresses. Este se trata de um projeto taxonômico abrangente que considera os inumeráveis tipos de "intermediários sexuais" existentes dentro do espectro hipotético entre a "pura feminilidade" e a "pura masculinidade" (Hirschfeld, 1910/2006). É um dos primeiros estudos sistematizados sobre a sexualidade humana com o desenvolvimento de diferentes descrições, da falta de atração pelo sexo oposto às inversões sexuais. Apesar do caráter psicopatológico do material devido à época de sua escrita, tanto Krafft-Ebing como Hirschfeld apresentam, respectivamente, a homossexualidade como uma das possíveis variações de gênero e diz que a transexualidade não pode ser reduzida à homossexualidade, ao fetichismo ou a qualquer perspectiva patológica.

Esse processo teve início com a clínica voltada para a homossexualidade, procurando diferenciar as monstruosidades, as anomalias e perversões. Posteriormente, a transexualidade se constituirá em objeto de observação, cujo movimento será o de inicialmente a separar do campo da homossexualidade e, posteriormente da intersexualidade (Lima, 2010, p. 64)

Castel (2001) conseguiu delimitar a história científica da transexualidade em quatro períodos claramente definidos: no primeiro momento, no início do século XX, com a emergência da Sexologia de Magnus Hirschfeld (1910/2006), se pautou numa taxonomia positivista da sexualidade; no segundo, durante as décadas de 1930 a 1960 com o desenvolvimento da endocrinologia e da perspectiva do behaviorismo endocrinológico; no terceiro, situado na década de 1950, durante a criação do conceito de gênero pela sociologia empírica norte-americana; no quarto, desde a década de 1970 há a reivindicação política pela despatologização da experiência da transexualidade (Castel, 2001; Borba, 2014a).

Em 1949, o termo "transexualismo" passou a ser utilizado por Cauldwell com a publicação do seu artigo Psychopathia transexualis. Nesse texto, o autor apresentava o caso clínico de uma menina que apresentava o anseio de ser menino, descrevendo, assim, a transexualidade como uma predisposição patológica de pertencer ao sexo oposto do de nascimento (Castel, 2001). A obra de Cauldwell apresenta materiais de cunho altamente psicopatológica, pois considera $\mathrm{o}$ "transexualismo" como uma predisposição geneticamente adquirida, que é combinada a 
determinadas disfunções na infância resultantes de uma imaturidade mental. Lima (2010), por sua vez, cunha o termo "norma transexual" para descrever a ordem discursiva que toma a transexualidade como uma patologia.

Conforme Bento (2006), a descrição dos sintomas e a construção científica da transexualidade seguiram duas correntes distintas: uma biológica, que visou traçar uma compreensão a partir da perspectiva de transtorno mental e de elementos biológicos do corpo, em que a cura de tal transtorno se daria pelas cirurgias de redesignação sexual; e a psicanalítica, que evidenciava a importância dos processos primários de socialização para a constituição da identidade de gênero. Alguns autores dessa última vertente questionam a importância dos procedimentos de redesignação sexual, pois acreditam que se trata de um desvio no desenvolvimento psicossexual, sendo resultado de um sintoma no registro do simbólico (Lionço, 2006).

No campo que se define como o dispositivo da transexualidade, pode-se citar três personagens principais, que têm as suas obras situadas na segunda metade do século XX. Eles contribuíram para o que o DSM-IV e o DSM-V chamam de "Transtorno de Identidade de Gênero" e "Disforia de Gênero", respectivamente. Trata-se do endocrinologista Harry Benjamin, do psicólogo John Money e do psicanalista Robert Stoller. Embora tais autores tenham concebido, de forma diferenciada, o atendimento clínico às pessoas transexuais, pois não existe unanimidade quanto a etiologia da transexualidade (Ceccarelli, 2003), "as teorias de Benjamin, Money e Stoller são textualizadas nos critérios diagnósticos da APA (American Psychiatric Association), da OMS (Organização Mundial de Saúde) e da WPATH (World Professional Association for Transgender Health) solidificando recursos semióticos que indexicalizam a transexualidade autêntica e servem de arcabouço diagnóstico para identificar 'transexuais verdadeiros'” (Borba, 2014a, p. 31).

O endocrinologista alemão, Harry Benjamin (1966/1999), publica o livro The transexual phenomenon e se torna uma das figuras científicas mais importantes quando se trata da experiência transexual. Ele teceu sistemáticas pesquisas mediante teses endócrinas sobre a estrutura do sexo humano e a gênese da transexualidade. Benjamin entendia que o sexo era composto por oito diferentes tipos: o cromossômico, o gonádico que se dividia em germinal e endocrinológico, o fenotípico, o psicológico, o jurídico e o social.

Para o cientista, o sexo psicológico era o mais fluido e poderia se desenvolver de forma autônoma aos demais. Porém, esse não era resultado de processos psicossociais, mas da ação de hormônios no comportamento de seres humanos. De acordo com o distanciamento entre o sexo psicológico e as outras modalidades, há diferentes níveis de intensidade que resultam em seis diferentes exemplares de transexualidade. Apenas os tipos $\mathrm{V}_{\text {e }} \mathrm{VI}^{6}$, que apresentam maior intensidade podem ser classificados como os "transexuais verdadeiros", os únicos a se beneficiarem

6 "Os tipos de transexual, segundo Benjamin, são: pseudo travesti (tipo I), travesti fetichista (tipo II), travesti verdadeiro (tipo III), transexual não-cirúrgico (tipo IV), transexual de intensidade moderada (tipo V) e transexual com alta intensidade (tipo VI)" (Borba, 2014a, p. 32). 
das cirurgias de redesignação sexual (Benjamin, 1966/2006; Borba, 2014). O autor os descreve como invertidos, ansiosos, assexuados ou, paradoxalmente, heterossexuais.

1) vive uma inversão psicossocial total; 2) pode viver e trabalhar como uma mulher, mas apenas vestir as roupas não lhe dá alívio suficiente; 3) intenso mal-estar de gênero; 4) deseja intensamente manter relações com homens e mulheres normais; 5) solicita a cirurgia com urgência; 6) odeia seus órgãos genitais (Benjamin, 1966/1999, p. 45).

Benjamin (1966/1999) descreveu "os transexuais verdadeiros" como aqueles que apresentavam um distanciamento entre o sexo de nascimento e o sexo psicológico pelo qual se identificavam. Assim, classificou o fenômeno a partir de suas especificidades, conferindo uma inteligibilidade, e estabeleceu nítidas diferenças entre as experiências da travestilidade, da homossexualidade e da intersexualidade. Lima (2010) ressalta que toda a tentativa de Benjamin resultou em classificar e tornar a transexualidade uma experiência singular.

$\mathrm{Na}$ década de 50, outro importante projeto que integrou a genealogia do dispositivo da transexualidade (Bento, 2006; Lima, 2010) foram os trabalhos realizados pelo psicólogo John Money e sua equipe. Também conhecido pela sua ocupação com crianças intersexuais no Hospital Universitário John Hopkins, no qual desenvolve parceria com Benjamin e Stoller.

Uma vez influenciada pela tradição da sociologia funcionalista norte-americana e na teoria de papéis de Parsons, a abordagem de Money (1969) se torna proeminente e diferenciada devido à inserção das noções de gênero e de sexo no contexto médico da época. Nesse sentido, pôde ampliar as discussões sobre as categorias de gênero, de identidades sociais e de papéis sexuais nas pesquisas sobre sexualidade até então pautadas sob parâmetros biológicos. Conforme tais ideias, ele publica, em 1955, as suas primeiras teses sobre a noção de identidade de gênero. Pode-se afirmar que a construção do seu pensamento foi marcada pelos estudos sobre a intersexualidade, diferenciando-a da transexualidade (Money, 1969; Lima, 2010).

Nesse sentido, o conceito de gênero foi trabalhado em suas publicações tendo proporcionado profícuo efeito na literatura científica do período. No entanto, é importante ressaltar que as suas ideias sobre os papéis sexuais reproduziam rígidos estereótipos de feminilidade e masculinidade e ainda traziam uma visão alinhada sobre expressão corporal, identidade de gênero e orientação sexual. A sua abordagem de gênero foi inserida no contexto médico para colaborar com a construção do diagnóstico de "Disforia de gênero" e de "Transtorno de Identidade de Gênero", visto que determinava a relação linear entre sexo, gênero (masculino e feminino) e sexualidade.

As explicações de Money (1969) sobre a formação da identidade sexual, que seria ter o sentimento de ser homem ou mulher, estava ligada às influências das relações familiares nos primeiros três anos de vida do ser humano. Condizia, dessa forma, ao mesmo momento de aquisição da linguagem e da estruturação do pensamento verbal. Tanto as relações familiares como as interações sociais ao longo do desenvolvimento humano seriam essenciais para a construção da identidade sexual. 
O psicanalista norte-americano Robert Stoller (1982; 2006) é também uma importante figura histórica que constitui a genealogia do dispositivo da transexualidade. Trata-se de um dos principais partidários da abordagem psicanalítica que defende o atendimento clínico para sujeitos transexuais. Seus livros A experiência transexual e Sex and gender tornaram-se um marco para os estudos transgêneros da época, pois participaram da consolidação de um projeto que tornou a transexualidade um fenômeno detalhadamente descrito pela ciência positivista. Stoller (1982) é uma das principais referências para profissionais de saúde que trabalham com transexuais até hoje (Borba, 2014), dada sua atribuição ao conceito de gênero.

A análise de Stoller (1982) enfatizou a influência das relações edípicas, ao longo da vida dos sujeitos, para o desenvolvimento da identidade de gênero condizente ao sexo atribuído de nascimento. O psicanalista se centrou em casos clínicos em que pais atribuíam problemas no processo de socialização de meninos vistos como "efeminados", termo tão qual é mencionado pelo autor. Nesse sentido, em seus livros concebe a gênese dos comportamentos de gênero considerados inadequados nessas crianças, que poderiam na vida adulta desenvolver o interesse pelas cirurgias de redesignação sexual.

Stoller (1982) afirma que a etiologia da transexualidade se refere ao trauma advindo de processos psicossociais decorridos de uma passagem defeituosa pelo complexo de castração. Por isso descreve a mãe do "transexual verdadeiro" como portadora de ciúmes dos caracteres masculinos e sente um desejo inconsciente de ser homem (Stoller, 1982; Bento, 2008). Ele torna-se um dos principais defensores contrários à cirurgia de transgenitalização, uma vez que acredita na possibilidade de evitá-la pela abordagem psicoterapêutica adequada, fazendo com que crianças "efeminadas" se desidentifiquem psiquicamente com a mãe masculina e freudianamente invejosa.

A partir das elaborações de Krafft-Ebing, Caudwell, Benjamin, Money e Stoller, do final do século XIX à segunda metade do século XX, a transexualidade passa a ser uma experiência compreensível dentro de determinado regime de inteligibilidade devido ao desenvolvimento da ciência sexológica. Hoje, no âmbito dos estudos queer e transgêneros, assume uma conotação radicalmente diferente.

Dentro da perspectiva psicopatológica, pode-se dizer que as pesquisas sobre a experiência seguiram duas correntes principais. Uma delas diz respeito ao seu afastamento dos distúrbios psicóticos tal qual a esquizofrenia. Essa vertente conseguiu classificar, mais especificamente, a transexualidade como um transtorno psicológico ligado ao sexo e ao gênero. A outra se conduziu por meio de sucessivos questionamentos da definição de sua gênese segundo bases orgânicas, essas críticas se fundamentam em pesquisas com pessoas intersexuais.

Desse modo, o dispositivo da transexualidade guiou-se principalmente por duas racionalidades distintas, mas complementares: a biomedicina e a matriz de inteligibilidade de gênero (Borba, 2014a; 2014b). Lima (2010) ressaltam que "esse duplo caminho proporcionou à transexualidade uma especificidade, uma tipologia, umas características e uma condução terapêutica 
própria, materializada nos centros de referência e nas equipes específicas no tratamento da transexualidade" (p. 61).

É importante complementar que existe, no regime de produção da verdade presente no dispositivo da transexualidade, um conceito de cura da experiência desviante, que está atrelada a um determinado padrão de saúde psicológica pautados por critérios sociais cisheteronormativos. Esse ponto de vista aponta que há, dentre todas as experiências sexuais e de gênero possíveis, um único processo de subjetivação possível e inteligível. A realização de desdobramentos do dispositivo da transexualidade permite contestar a ideia de "sexo" construída para subsidiar a manutenção de um projeto representacional em ciência.

\subsection{O lugar da Psicologia no debate sobre as experiências e os estudos transgêneros}

A Psicologia é constituída por um conjunto de saberes, técnicas e práticas, e, inegavelmente, traz indicações sobre o manejo das práticas de subjetivação. É importante, por isso, discutir sobre a importância do saber psicológico na esfera da constituição das subjetividades trans. A partir de um breve panorama, situa-se algumas concepções de gênero e de sexualidade no âmbito da Psicologia para contextualizar o seu papel enquanto dispositivo partícipe do processo transexualizador.

O debate que se evoca diz respeito a como as/os psicólogas/os podem se encontrar numa posição paradoxal a que são convocadas/os, entre realizar pareceres psicológicos a partir de critérios e protocolos normativos e promover atendimentos com base na saúde mental de pessoas trans, pois a demanda de acesso à saúde está vinculada à psicopatologia de formas singulares de subjetivação. Trata-se de analisar, inclusive, o contexto em que a pesquisadora se insere: o setting de atendimento clínico às pessoas trans solicitantes da cirurgia de redesignação sexual.

É possível observar, mediante um recorte histórico, a trajetória em que a Psicologia, juntamente à Psiquiatria, tem se constituído discursivamente como saber estratégico para patologizar as experiências sexuais e de gênero (Rose, 2011, Foucault, 1988; 2001). As Ciências Humanas, incluindo a Psicologia, produziram determinados discursos sobre gênero e sexualidade ao longo da modernidade ocidental. Borges, Canuto, Oliveira e Vaz (2013) mostram que o saber psicológico tem se baseado numa visão normativa e polarizada no que diz respeito às expressões de gênero e às sexualidades. Além disso, as/os autoras/es pontuam que as temáticas de gênero permanecem marginais ou ainda invisíveis no campo de estudos da Psicologia (Narvaz, 2009; Maués, 2007; Nuernberg, 2005).

É importante ressaltar a existência de várias psicologias comprometidas com diferentes projetos políticos, por isso existem várias abordagens de gênero na área. Desde o século XIX, enquanto produção de uma expertise, tem sido formada no interior de uma tecnologia biopolítica, ou seja, de um gerenciamento sistemático da subjetividade (Rose, 2011). Assim sendo, compõe-se como uma autoridade heterogênea e "um amálgama de conhecimentos e técnicas oriundos de diferentes 
fontes" (Rose, 2011, p. 123). Enquanto disciplina, "a Psicologia oferece tanto uma fundamentação na verdade como algumas fórmulas de eficácia" (Rose, 2011, p. 124). É exatamente essa a abordagem a ser discutida no que se refere aos jogos de verdade produzidos pela disciplina.

Então, as ciências psicológicas têm sido capazes de desenvolver tecnologias de gênero com base em dispositivos discursivos para gerir modos de subjetivação. Os/as sujeitos/as se tornaram objetos do conhecimento psicológico, o que tem conferido inteligibilidade a sua existência, para serem filiados/as aos padrões de normalidade. Passam a ser objetos determinados dotados de subjetividade e alvo de controle biopolíticos, a partir de um conjunto de agências, por isso algumas Psicologias (muitas delas seguem correntes positivistas) remetem ao gênero como uma categoria pautada por regras normativas. A partir de discursos produzidos, há a possibilidade de gerar resultados nocivos a algumas experiências humanas, pois podem autorizar a naturalização da violência e reforçar os binarismos de gênero. É inegável, por exemplo, a contribuição dos saberes psi (a Psicologia, a Psiquiatria e a Psicanálise) para a construção do dispositivo da transexualidade (Bento, 2006; Lima, 2010).

Assim, a Psicologia constituiu-se enquanto saber científico, na modernidade, juntamente às outras Ciências Humanas, desenvolvendo-se como produções instituintes de práticas de observação e de descrição de comportamentos. Tais procedimentos e tecnologias tinham como objetivo vigiar, controlar e disciplinar os comportamentos das pessoas. Para exemplificar, a categoria de "identidade de gênero" foi construída para tornar os seres humanos objetos inteligíveis e, portanto, passíveis de governamentabilidade. Segundo a cronologia do fenômeno transexual delineada por Castel (2001), essa noção foi criada para validar o conceito de "Transtorno de Identidade de Gênero". Daí a construção do conhecimento científico se apresenta com o objetivo de medicalizar a transexualidade e construir sua nosografia psiquiátrica.

Pode-se localizar o surgimento dos saberes psi no contexto de proliferação dos discursos sobre a sexualidade simultaneamente ao aumento das práticas de confissão e ao surgimento da subjetividade como domínio de investigação. As relações de poder-saber ligadas às práticas de confissão se transformaram ao longo da modernidade e se conformaram no que Foucault (1988) denominou de scientia sexualis, como foi explorado anteriormente. É nesse sentido que a sexualidade passa a ser um domínio de conhecimento a partir dos processos considerados psicopatológicos, em que são requeridas intervenções terapêuticas para a normalização dos sujeitos.

No marco das diferentes epistemologias, os estudos de gênero foram introduzidos na Psicologia a partir de duas correntes principais: uma empiricista, baseada em duas abordagens diferentes e seguiram uma perspectiva essencialista de socialização, dizendo que existem diferenças inatas e estáveis entre os sexos; a outra construcionista que depois derivou a pós-moderna, pautada por uma concepção da construção dos gêneros de modo social e discursivo (Nogueira, 2001a; 2001b; Harding, 1986). A partir das décadas de 70, houve uma revisão de conceitos na psicologia científica 
realizada até então devido às críticas das autoras feministas da segunda geração ${ }^{40}$. Mas, de acordo com Nogueira (2001a), muitas dessas críticas seguiram o paradigma empiricista e mais recentemente seguem o viés pós-moderno. Na Psicologia, o empiricismo feminista questionou os vieses sexistas e androcêntricos da pesquisa científica.

Durante a Segunda vaga do feminismo, quando das primeiras críticas à Psicologia e ao estudo das diferenças sexuais em particular, estas foram essencialmente do tipo empiricista, isto é, eliminados pela adesão estrita às normas metodológicas já existentes da pesquisa científica. Desafiam essencialmente o método científico que consideram incompleto, não as normas da própria ciência, isto é, embora admitam a emergência de novas questões, mantêm sem questionar a lógica do processo de pesquisa e a lógica da explicação científica (Nogueira, 2001b, p. 12).

Na primeira metade do século XX, a perspectiva essencialista direcionou o paradigma das diferenças sexuais na Psicologia e indicou que havia diferenças inatas e imutáveis entre os sexos. $\mathrm{O}$ gênero passou a ser compreendido como uma categoria estanque e assumiu um caráter altamente determinista, sendo que era concebido como um marcante traço de distinção entre as personalidades e os processos cognitivos ditos "masculinos" e "femininos", ou seja, era visto como "uma propriedade estável, inata e bipolar de diferenciação sexual" (Nogueira, 2001; Borges, Canuto, Oliveira \& Vaz, 2013, p. 733). Assim, as diferenças de gênero eram observadas como qualidades essenciais de dois gêneros psicológicos distintos, coerentes com os sexos biológicos e estáveis ao longo do desenvolvimento humano.

Nogueira (2001b), ressalta que "desde 1910 que se assiste na psicologia à afirmação das diferenças sexuais para sustentar a inferioridade feminina, limitando a sua esfera de ação, restringindo a sua autonomia e liberdade de movimentos" (p. 10). No contexto dessa posição empiricista, o gênero passa a ser visto segundo a perspectiva do dimorfismo sexual (Laqueur, 2001) e, assim, tem sido definido em termos de uma diferença dicotômica e hierárquica.

Nesse sentido, a diferença entre os gêneros passou a ser explicada, num primeiro momento, pela androginia que desafiou a ideia da existência de um dualismo de gênero e da ligação entre o sexo biológico e o gênero psicológico (Morawski, 1990) e, num segundo, pela teoria dos papéis sociais no âmbito da Psicologia Social, em que homens e mulheres passam a internalizar papéis específicos, tomados a priori, no processo de socialização.

É importante explicar o modelo da androginia. Esse "continua a reconhecer os conceitos

40 A primeira onda do feminismo pode ser localizada entre os séculos XIX até meados do século XX. As feministas desse período tiveram como objetivo a luta pela promoção da igualdade de direitos ao voto, por isso foram também chamadas suffragettes. Desde o início do movimento feminista houve campanhas pelos direitos sexuais, reprodutivos e econômicos das mulheres. A segunda onda é marcada pela obra $O$ segundo sexo de Simone de Beauvoir e se inicia na década de 60. As feministas de segunda geração questionavam as estruturas de poder sexistas do patriarcado, dessa forma, analisaram os fatores que reproduzem as desigualdades culturais e políticas das mulheres, lutaram pelo direito à autonomia do próprio corpo e pela igualdade entre os gêneros. A terceira onda do feminismo, que se iniciou no final da década de 80, deu especial atenção a dimensão micropolítica, por isso questionou a universalização da categoria "mulheres" do feminismo de segunda geração, ao levar em consideração o recorte social de raça e classe. Foi marcado pelas obras de bell hooks, Audre Lorde, Judith Butler, dentre outras importantes autoras. 
convencionais de feminilidade e masculinidade, retendo o dualismo clássico e a afirmação de algumas diferenças de gênero reais e internas do ponto de vista psicológico" (Nogueira, 2001b, p. 14). Segundo algumas análises quantitativas, houve uma valorização da masculinidade ao representar os avatares do comportamento andrógino. Enquanto na teoria dos papéis há de forma implícita, ou ainda explicita, a incitação dos estereótipos de gênero, "os papéis de gênero são definidos como aquelas expectativas partilhadas acerca das qualidades e comportamentos apropriados dos indivíduos, em função do seu gênero facilmente definido" (Nogueira, 2001b, p. 15). Então, essa abordagem empiricista, que tentou explicar a socialização em relação ao gênero, entendeo como um desenvolvimento interno ao sujeito e se conduz de forma contínua e estática.

A segunda perspectiva identificada na Psicologia, segundo Nogueira (2001a; 2001b) e Harding (1986), é a construcionista ou pós-moderna. Essa tem sido baseada nos trabalhos das feministas da terceira geração, que começaram a surgir por volta dos anos 80, e toma como uma de suas principais referências a obra de M. Foucault. O pós-modernismo evoca a multiplicidade, o inédito e o paradoxal, trata-se de características que, em geral, o positivismo e o empiricismo buscavam suprimir em suas teorizações. Tal concepção questiona a universalidade das noções de sexo, gênero e sexualidade, isso porque não há um saber pré-discursivo, ou seja, todo conhecimento é gerado pela linguagem, que é capaz de representar as experiências humanas. Assim, contrapõe-se a essencialização do feminino e do masculino concebidos pelos determinantes biológicos:

o construcionismo social assume o gênero como uma construção social, um sistema de significados que se constrói e se organiza nas interações, e que governa o acesso ao poder e aos recursos. Não é por isso um atributo individual, mas uma forma de dar sentido às transações: ele não existe nas pessoas, mas sim nas relações sociais (Nogueira, 2001a, p. 21).

Por isso, as experiências homossexuais e trans são vistas como historicamente construídas, depende da cultura e das relações sociais estabelecidas, o que possibilita pensar que há diferentes formas de expressão de gênero e de sexualidade. Além disso, houve a introdução da perspectiva queer que rompe com a ideia de uma "identidade de gênero" estável, inata e coerente. As ideias de Butler, discutidas na primeira sessão do trabalho, problematizam a categoria de sexo, pois é também socialmente constituída. É relevante ressaltar que há uma diferença entre o queer e o construcionismo, pois a primeira perspectiva tece uma crítica radical à ontologização das identidades, ao questionar os papéis sociais de gênero e a instabilidade das diferentes expressões sexuais.

Tanto a perspectiva construcionista quanto a queer produziram transformações epistemológicas no campo. As teorias pós-estruturalistas se propagaram por todas as disciplinas nas Ciências Humanas e geraram um impacto na teorização sobre gênero na psicologia. Esse é o arcabouço teórico em que esse trabalho se inscreve. Assim, é inegável que a análise crítica do feminismo pós-modernista tem oferecido importantes contribuições para as categorias do discurso psicológico, conferindo uma abordagem dinâmica e auto-reflexiva. A construção de uma produção 
científica feminista (Haraway, 2006) colabora com a compreensão das dinâmicas e dos processos psicológicos pelos quais o gênero exerce influência. Sendo analisado a partir do qual as narrativas pessoais e coletivas são criadas (Nogueira, 2001a; 2001b), o gênero é construído processualmente e pode ser lido como produto das práticas de subjetivação.

O desafio é fazer com que muitas dessas contribuições pós-estruturalistas permita conceber uma Psicologia ou, particularmente, uma psicologia do desenvolvimento numa perspectiva crítica, politicamente implicada e que possa desconstruir os posicionamentos tradicionais de sexualidade, de gênero e de subjetividade (Fausto-Sterling. 2012). Ou seja, trata-se de questionar qualquer generalização ou essencialismo discursivo presente nessas concepções, sem cair num relativismo epistemológico. No percurso dessa cartografia, os processos investigados são situados num locus específico de problematização, pois se parte de reflexões sobre um ponto de ruptura paradigmático em Psicologia, a saber: o desenvolvimento de novos regimes de subjetivação no contemporâneo em que se evoca as experiências trans.

É preciso salientar as demandas específicas de direitos às pessoas trans como "a despatologização da experiência” (Bento, 2006; Murta, 2011) para o acesso aos serviços de saúde e a retificação de nome e de sexo nos documentos de identidade. Ambos podem sustentar a ideia "da necessidade da cirurgia". No entanto, hoje, estas modificações garantem a legalidade dos documentos e a sua adequação à identidade social do sujeito, podendo minimizar possíveis experiências de constrangimento cotidianas.

A Nota Técnica sobre o processo transexualizador e as demais formas de assistência às pessoas trans e a Resolução 001/99, ambas do Conselho Federal de Psicologia (CFP), configuram um marco nas políticas de promoção da saúde e da cidadania para as pessoas LGBT $^{41}$. Numa atitude preocupada com aplicações nocivas do saber psicológico, a classe profissional estabeleceu regras normativas e parâmetros éticos no combate ao diagnóstico do gênero e a patologização de todas as possibilidades de expressão que diferem da norma heterossexual (Kahhale, 2011). No entanto, é importante considerar que a categoria "cisnormatividade" não estava presente nos documentos à época de suas publicações.

O que antes era tratado como psicopatologias sexuais e transtornos de identidade de gênero,

41 Atualmente o CFP alimenta o site http://despatologizacao.cfp.org.br para a divulgação de materiais como publicações audiovisuais, blogs, links diversos, sites das Associações (Nacional de travestis e transexuais, do IBRAT - Instituto Brasileiro de Transmasculinidade, entre outros), legislações nacionais e internacionais, últimas notícias que abrangem a temática da transgeneridade à nível mundial ou restritas ao território brasileiro. Trata-se de uma iniciativa que visa a interlocução de pessoas trans, através do relato de suas próprias experiências de vida, e de psicólogos/as que têm trabalhado com esse público. A ideia é ampliar o debate para as/os psi, visando a desconstrução de visões psicopatológicas e de estigmas que retroalimentam a transfobia no âmbito da prática profissional. Por isso, é um projeto que visa fomentar o relato de experiências inovadoras, por meio de relatórios psicológicos diferenciados ou de outros modelos de atuações nos serviços de saúde direcionadas à comunidade trans em ambulatórios do Sistema Único de Saúde, em práticas psicoterapêuticas privadas ou espaços educacionais (educação básica, em geral) e universitários. 
agora passa por um processo de revisão de posturas, conceitos e práticas, especialmente, devido às reivindicações das teóricas feministas, transfeministas e dos movimentos sociais LGBT, em geral. Mediante tais revisões epistemológicas, a sexualidade e o gênero são vistas como social e historicamente construídos, possibilitando-nos pensar que existem diferentes formas de constituir variadas e múltiplas expressões. É evidente a necessidade de se produzir discursos em Psicologia que se articulem a uma nova prática política, problematizando teorias patologizadoras sobre a sexualidade e o gênero segundo tentativas de reificação das experiências de mulheres, homossexuais e de pessoas trans. Em especial, faz-se necessário questionar a cisheteronormatividade como um discurso capaz de regular as relações de gênero e as práticas sociais.

A escuta clínica do/a psicoterapeuta ou de profissionais psi em outros contextos de atuação, como hospitalar, organizacional ou educacional, não poderia reforçar aspectos estereotipados dos gêneros masculino e feminino como critérios psicodiagnósticos e nem os fixar como obrigatórios para a sua condução. O que foi pensado a partir de uma cartografia do espaço-tempo da pesquisa é a possibilidade de construir uma teoria sobre a produção da subjetividade que não reproduza o dispositivo da transexualidade. Este seria um viés de normalização dos sujeitos no âmbito da prática terapêutica ou profissional, em geral, consoante um determinado parâmetro de saúde mental relacionado ao gênero e à sexualidade. No entanto, é preciso situá-lo e discuti-lo, visto que, de algum modo, as sessões terapêuticas funcionam como dispositivos agenciadores de subjetividades (Oliveira, 2013; 2014).

A Psicologia, especialmente a Psicanálise de vertente freudiana, foi construída com base em teorias que articulam o desenvolvimento sexual ao desenvolvimento psíquico. Na mesma linha de raciocínio, pode-se afirmar a necessidade de um ambiente psíquico seguro para o desenvolvimento de uma sexualidade saudável e livre de repressões. Dessa forma, torna-se um dever da Psicologia enquanto ciência, e nosso enquanto profissionais dessa área, atentar para o desenvolvimento das questões políticas em torno da sexualidade e seu impacto na psiquê.

Muitos/as psicólogos/as têm se deparado com as experiências trans, tanto os/as que atuam do processo transexualizador do SUS como aqueles/as que acompanham pessoas trans no contexto de seus consultórios particulares e, em geral, tem assumido posturas segundo performances discursivas (Borba, 2014a). Oliveira (2013; 2014) e Borba (2014a) analisaram práticas de profissionais, que atendiam transexuais no contexto do hospital, e observaram estratégias de negociação implicadas nas narrativas de psicólogos/as e psiquiatras.

Para Borba (2014), existe uma receita ou uma pedagogia promovida pelos profissionais de saúde, que objetiva tornar as pessoas com demanda cirúrgica de transgenitalização "transexuais verdadeiros", ou seja, devem assumir, para as/os profissionais, a sua condição de portadores/as de um "transtorno de identidade de gênero" e seguir um script previamente estipulado. Trata-se de cumprir critérios validados por protocolos do Instituto Internacional Harry Benjamin importados ao contexto brasileiro. O processo transexualizador passa a ser uma trajetória de socialização e de 
convencionalização de discursos performáticos da ciência moderna norte-americana. A partir do conhecimento das regras impostas para o acesso à cirurgia de redesignação sexual, a pessoa trans passa a atuar conforme uma estratégia discursiva para provar e convencer a equipe multidisciplinar de que é "um/a transexual verdadeiro/a" (Bento, 2006; Teixeira, 2009; Oliveira, 2013; Borba, 2014a; 2014b).

O Relatório de Força-Tarefa da Associação Psicológica Americana (APA) publicou, em 2009, uma pesquisa com a participação de estudantes de pós-graduação para compreender suas familiaridades com questões referentes às identidades de gênero e às diferenças de gênero ${ }^{42}$ (APA, 2009). Durante a investigação realizada, encontrou-se como resultado a formação insuficiente e limitada de psicólogos/as e de outros/as profissionais de saúde mental para lidar com situações e especificidades das experiências de pessoas trans, em geral. Pela ausência de critérios quanto aos cuidados afirmativos, essa escassa formação pode causar danos às pessoas que vivenciam tal condição.

O nível significativo de estigma social e discriminação que TGNC associadas às consequências da saúde mental e da falta de familiaridade dos/as psicólogos/as (sic) com os cuidados trans-afirmativos levaram a força-tarefa da APA a recomendar que as diretrizes de prática psicológica sejam desenvolvidas para ajudar os/as psicólogos/as a maximizar a eficácia dos serviços oferecidos e evitar danos ao trabalhar com pessoas TCNC e suas famílias (APA, 2015).

Tecer uma compreensão psicológica sobre a constituição da subjetividade em pessoas trans é um desafio, ainda mais pensada a fim de conduzir critérios psicodiagnósticos para a cirurgia de redesignação sexual, pois nos faz pensar sobre qual ética e política queremos conduzir a prática em psicologia. Por isso, busca-se contribuir para o avanço das diretrizes de atendimento psicológico aos sujeitos trans, discutindo o lugar do psicodiagnóstico e o papel da/o psicóloga/o nesse contexto.

Um psicodiagnóstico não patologizante seria aquele que apontaria a condição de vulnerabilidade social em que o sujeito se encontra por viver sua condição de resistência às normas de gênero. Além disso, seria importante apontar a necessidade de uma rede de assistência para os sujeitos e não reproduzir a nomenclaturas de manuais de diagnósticos. A ideia é promover uma

42 “Em 2005, Representantes do Conselho da APA autorizou a criação de uma força-tarefa sobre Identidade de Gênero e Diferença de Gênero, cobrando que, após o relatório publicado, fosse necessário revisar as políticas da APA relacionadas com as pessoas TGNC e oferecer recomendações à APA para melhor atender às necessidades das pessoas TGNC. (...) Em 2009, em um extenso relatório sobre o estado atual da prática psicológica com as pessoas TGNC, a Força-tarefa (composta por dez membros com uma prática psicológica e expertise acerca da experiência de pessoas TGNC, dos quais cinco eram pessoas identificadas dentro de espectro variado de identidades de gênero e as outras eram cinco pessoas cisgêneras) determinou que havia conhecimento suficiente no campo para justificar o desenvolvimento de diretrizes práticas para as populações de TGNC (...) A relativa falta de conhecimento dos/as psicólogos/as sobre o TGNC e os cuidados trans-afirmativos, o nível de estigma social e discriminação que as pessoas da TGNC enfrentam e as significativas consequências de saúde mental que as pessoas vivem oferecem como resultado uma necessidade obrigatória de diretrizes de prática psicológica para esta população.” (APA, 2015, p. 833, tradução livre). 
discussão sobre a possibilidade de uma prática psicológica "trans-afirmativa" (APA, 2015) ${ }^{43}$, uma vez que é necessário um exercício profissional que promova cuidados "respeitosos, conscientes e que apoia as experiências de vida das pessoas transgêneras e daquelas que apresentam a nãoconformidade de gêneros (TGNC)" (APA, p. 832-833, tradução livre).

À primeira vista, a pessoa trans realiza a cirurgia com o objetivo de readequação às normas e para atuar de acordo com os papéis de gênero masculino e feminino esperados socialmente. No entanto, é preciso considerar que há o desejo do sujeito de ser reconhecido como uma pessoa digna de respeito, independente da realização da cirurgia, sem estar, portanto, sujeito à exclusão e às formas específicas de violência como a transfobia (Jesus, 2014). Por outro lado, é inegável que a transformação corporal do processo transexualizador forja um lugar para pessoas trans na sociedade contemporânea.

Pensar o lugar da psicologia no âmbito das experiências trans, visando a despatologização e a desestigmatização, envolve recriar uma leitura singular sobre quem é e o que pode se tornar o/a humano/a. Nesse sentido, a experiência de transitar entre os gêneros é uma experiência de constituição do ser humano na cultura, traduzindo como uma das formas de subjetivar-se.

O que a experiências trans indicam é que as nossas subjetividades são constituídas por determinados dispositivos de saber-poder normalizadores, que determinam o que é normal ou saudável. Trata-se de avaliar um determinado modo de produção da verdade, sendo relevante ponderar acerca da atuação das/os profissionais psi por meio de práticas de resistências aos padrões hegemônicos de psicodiagnósticos, ambos evocados pelo saber médico-psiquiátrico e pelas práticas psicológicas historicamente consolidadas.

As práticas profissionais psicológicas, que visam promover ações afirmativas para as experiências trans, é um vasto território ainda a ser explorado, pois é ainda um campo emergente de literatura acadêmica e pesquisa (APA, 2015). Devido ao fato de os "Estudos Transgêneros" ser um domínio formado a partir de uma perspectiva interdisciplinar, tem sido uma das principais referências para se avaliar possíveis orientações para a atuação de psicólogas/os. Estas podem aspirar a formação de práticas profissionais ética e politicamente implicadas com as atuais demandas de gênero e sexualidade.

43 As "Diretrizes para a Prática Psicológica com pessoas trans e pessoas que apresentam a nãoconformidade de gêneros (TGNC)" da APA considera a singularidade das experiências humanas e, assim, põe em evidência as especificidades das instruções apontadas no referido texto. Desse modo, salienta que "como as questões de identidade de gênero são muitas vezes confundidas com questões de expressão de gênero ou orientação sexual, a prática psicológica com a população da TGNC garante a aquisição de conhecimentos específicos sobre preocupações exclusivas das pessoas da TGNC que não são abordadas por outras diretrizes práticas (APA, 2012). É importante notar que estas Diretrizes não pretendem abordar alguns dos conflitos que as pessoas cisgêneras podem experimentar devido às expectativas da sociedade com relação aos papéis de gênero, nem se destinam a tratar pessoas intersexuais" (p. 833, tradução livre). 


\section{MÉTODO: A OFICINA DA PESQUISA}

Construir um projeto de pesquisa envolve saber que há uma atitude de acolhimento ao tema e um delicado processo de encontro com o que se quer conhecer. Observar como o método se insere durante a construção de um projeto tem a ver com a própria experiência do pesquisar: o método possibilita caminhar a partir de uma dada direção e dá contorno à trajetória da pesquisadora.

No entanto, a perspectiva representacional em ciência não condiz com o pesquisar com a cartografia. O conceito de método assume um sentido que diz respeito à tradição de um determinado paradigma. Trata-se de uma corrente filosófica realista de origem cartesiana e positivista. Para a primeira, a mente é o espelho de representação da realidade, uma vez que todos os fatos estão incorporados à mente do cientista, a pesquisa não necessita envolver a sua experiência. No positivismo, a corrente filosófica inspiradora é o empirismo que presume o conhecimento pautado na atitude natural, assim, a ideia de representação cartesiana é descartada ao se enfatizar que os fatos e dados reais são os objetos a serem pesquisados pelo cientista. Existem abordagens em psicologia que nasceram dessas perspectivas de valorização do real como meta de investigação dos seus objetos/campos de estudo.

A intenção é promover um deslocamento no uso da palavra método e, a partir de uma mudança de vocabulário, propõe-se uma reversão de sentido para não mais se pautar por técnicas que visam ordenar o mundo e regular a vida dos seres humanos segundo uma única via. A técnica moderna, segundo a qual a noção de método se insere, põe ordem ao mundo por meio de normas abstratas e concebe o caminho da pesquisa em programas pré-fixados. De outro modo, indica-se a técnica em cartografia como poiesis ${ }^{44}$, porque é durante o percurso que se criam os propósitos de uma investigação no intuito de agenciar vida e pesquisa.

É importante, então, delimitar como os conceitos operam e estão implicados ao processo desta pesquisa. Na cartografia, a seção método poderia ser traduzida mediante a união de duas imagens: a atividade da cientista no laboratório e a da artesã num ateliê de arte. Tomando o exemplo da cientista cartógrafa como artesã numa oficina de pesquisa e de escrita, há a possibilidade de incorporar a experiência ao processo de invenção, quando os acontecimentos são produzidos ${ }^{45}$. A noção de experiência é, portanto, um interessante parâmetro conceitual para avaliar as dinâmicas que

44 Nesta tese, desenvolvi uma proposta da política de escrita em cartografia como poiesis.

45 Para Zourabichvili (2016), leitor de Deleuze, "acontecer é o que nunca cessa, apesar de sua instantaneidade. No acontecimento, os diferentes momentos do tempo não são sucessivos, mas simultâneos. Não é somente o presente, é Cronos inteiro (sucessão dos presentes) que vacila. $\mathrm{O}$ acontecimento se desdobra em dois modos temporais concomitantemente, Cronos e Aion. A distinção de Cronos e Aion pode, portanto, ser enunciada de outra maneira: o tempo já não mede um movimento. A conexão de subordinação é revertida, e agora o movimento é que é subordinado ao tempo, à sua heterogeneidade, à infinidade de suas dimensões. O acontecimento já não é o que tem lugar no tempo, simples efetuação ou movimento, mas a síntese transcendental do irreversível, que reúne e distribui o antes e o depois de ponta a ponta de uma cesura estática, o Instante" (p. 117-118). 
existem entre os projetos científico e artístico, por isso seria interessante articulá-los dentro da acepção travessia. Nesse sentido, a experiência é uma força motriz para a política de escrita em qualquer pesquisa, pois faz mover os significantes, promove ondas entre o saber e o fazer, oferece ao sujeito perícia durante o caminhar.

O sujeito da experiência é, segundo Larrosa (2014), um sujeito que se "ex-põe" às situações de desejo, de vulnerabilidade e de risco. Desse modo, o desafio da pesquisadora cartógrafa é exporse ao que a toca, ao que mobiliza seus afetos e perceptos. A própria palavra experiência vem do latim experiri e significa provar e experimentar: "a experiência é, em primeiro lugar, um encontro ou uma relação com algo que se experimenta e se prova" (Larrosa, 2014, p. 26). Além disso, Larrosa complementa, "o radical peri, que se encontra também em periculum, perigo, dá a conotação de que a experiência apresenta a dimensão de travessia e de perigo" (p. 26).

Pode-se dizer que o saber da experiência se deu, historicamente, numa relação entre conhecimento e vida, mas a partir de regimes diferentes ou, melhor, opostos. Um concebeu a experiência como resultado de um experimento, trata-se da perspectiva da ciência moderna que a converteu em um elemento seguro do método. A outra perspectiva, dentro da qual a prática da cartografia pode se inserir, concebe a experiência como processo e, assim, é possível traçar um conhecimento contingencial e subjetivo. Se o resultado do experimento é generalizável, a experiência é singular, relativa, não-linear, um meio pelo qual é possível tecer um saber encarnado.

O desafio é, para todos os efeitos, o escrever ou reescrever a ciência e não produzir um texto puramente literário, autobiográfico ou ainda poder-se-ia pensar na confecção de uma obra de arte. Não se trata disso. Para se traçar a escritura de uma tese é necessário encontrar um diagrama textual que esteja adequado unicamente com o seu campo problemático (Arendt, 2016). De acordo com tal proposta, constrói-se uma oficina de pesquisa onde se elaboram os dispositivos de pesquisa e onde são constituídos os analisadores por meio de uma prática ética, estética e politicamente implicada.

Durante a investigação, a pesquisadora primeiro avaliou como poderia desenvolver as estratégias de como habitar um território de pesquisa mediante um princípio principal: construí-lo sem metas rígidas e pré-fixadas. Ao longo do trajeto, buscou-se, portanto, traçar uma linha de coerência entre os acontecimentos e as escolhas feitas logo em seguida. Ou seja, a oficina de pesquisa com a cartografia é uma prática inventiva, pois os acontecimentos são analisadores que, em geral, enunciam uma "questão problema" na medida em que surgem.

A ideia central foi acompanhar um percurso sobre como subjetividades contemporâneas têm sido produzidas por um conjunto de técnicas, práticas e dispositivos. Nesse sentido, propõe-se argumentar sobre as práticas de subjetivação a partir da análise dos regimes de verdade presentes no dispositivo da transexualidade. É possível dizer que ele conduz a certos tipos de operação e de agências em que os modos de subjetivação são produzidos em experiências tanto transgêneras quanto cisgêneras. Por isso, traduz visibilidades e produz enunciações sobre os regimes de saber-poder normalizadores. Estes se organizam e se efetuam em modelos dominantes de relações de gênero 
marcados pela cisheteronormatividade e pelo binarismo de gênero, que são vistos como lógicas de captura e de relações de exploração sobre os sujeitos.

O campo problemático é sobre como os processos de subjetivação e gênero se agenciam mutualmente, com foco em práticas que se constroem a partir de transgressões às hegemonias. Então, analisa-se discursos para desnaturalizar lógicas tratadas como invisíveis dentro de sistemas de representação relativos ao sexo e ao gênero. Assim, o conceito de dispositivo da transexualidade como um processo de subjetivação possibilitou construir um contexto analítico propício no intuito de problematizar perspectivas que tratam as experiências trans a partir de um viés cisheteronormativo e psicopatológico.

Eleger o gênero como critério de subjetivação numa perspectiva processual permitiu considerar como a experiência humana pode ser vista a partir de uma multiplicidade constituinte, sem uma demarcação a priori sobre o que cada sujeito é ou como deveria viver. De outro modo, as experiências trans são pensadas a partir de seus processos de produção da subjetividade.

Nesse processo, a preocupação principal foi possibilitar que o próprio campo de investigação trouxesse indicadores, incluindo os encontros e os desencontros, para que as escolhas ou os desenhos da problematização fossem delimitados. Existe uma semelhança entre esta escrita e o modo de como o campo foi conduzido, pois foram pensados como contingentes entre si.

Houve um convite para que os acontecimentos e os analisadores pudessem emergir, bem como houve um atrativo à participação dos sujeitos, uma vez que a interação foi conduzida com base nas políticas de amizade, a fim de traçar um plano de acesso à experiência. Dessa forma, o percurso seguiu a seguinte trajetória: 1) atuação como psicóloga; 2) as observações exploratórias do movimento social de homens trans e de um grupo de jovens LGBT da cidade de Brasília; 3) a realização das entrevistas narrativas e episódicas, mediante um roteiro (anexo 1) com os sujeitos trans, auto-denominados binários ou não-binários, em encontros que variariam entre um a três momentos para cada sujeito.

Com a intenção de possibilitar o entendimento de como se desenvolveu a pesquisa, esta seção foi dividida em tópicos: cuidado ético-institucional; descrição espaço-temporal do processo de pesquisa; quem são os sujeitos participantes da pesquisa?; como foi possível engajar o campo de pesquisa?; os dispositivos da pesquisa (instrumentais, técnicos e teórico-analíticos); os analisadores e os diagramas; os procedimentos de construção e de análise das informações: observações exploratórias com base no diário de campo da pesquisadora e análise das entrevistas narrativas e episódicas.

\subsection{Cuidado ético-institucional}

Para que se desse início à pesquisa de campo, o projeto foi submetido à Plataforma Brasil pelo site http://aplicacao.saude.gov.br/plataformabrasil/login.jsfe e, posteriormente, aprovado pelo Comitê de Ética em Pesquisa do Instituto de Ciências Humanas (CEP/IH) da Universidade de 
Brasília (Parecer n. 820.944). Nesse sentido, respeitou todas as Diretrizes e Normas de Pesquisa Envolvendo Seres Humanos, instituídas pela Resolução 466/12 do Conselho de Saúde do Ministério da Saúde. Durante a pesquisa empírica, os procedimentos éticos, como a apresentação da pesquisa, a garantia do sigilo e a assinatura de consentimento livre e esclarecido pelos/as participantes (anexo 2), foram cuidadosamente obedecidos.

\subsection{Descrição espaço-temporal do processo de pesquisa}

É importante ressaltar que o momento inicial dessa pesquisa se deu a partir do contato da presente pesquisadora com a experiência trans, em um contexto de atuação profissional em psicologia. O que consistiu em uma matéria de reflexão para o trabalho e surgiu como um acontecimento inesperado, ou seja, um analisador. Observar a experiência investigada e a própria prática profissional desafia os padrões de neutralidade na produção científica positivista, no entanto, constitui-se como um recurso metodológico na cartografia: "a instalação da pesquisa cartográfica sempre pressupõe a habitação de um território, o que exige um processo de aprendizado do próprio cartógrafo (...) o aprendiz-cartógrafo deve cultivar uma posição de estar com a experiência e não sobre esta" (Alvarez \& Passos, 2009, p. 135). Assim, essa imersão permitiu compor o delineamento do campo problemático da investigação de modo processual. A relação direta com a vivencia de pessoas trans me ofereceu suporte para saber o que e como pesquisar a produção de subjetividades, no que tange ao gênero e à sexualidade, a partir de experiências concretas.

O que se constituiu como análise foi o meu processo como psicóloga e pesquisadora. Esse contato inicial foi produtivo e permitiu pensar como poderiam ser confeccionados o roteiro de entrevistas (que serão explicados mais adiante nesta seção) e também se constituiu um desafio, principalmente, no momento de produzir um laudo não pautado por critérios psicopatológicos. Durante a realização de tal procedimento, é necessário atender aos critérios exigidos pelas normas dos Conselhos de Medicina e de Psicologia, pois tanto para o caso de da cirurgia de redesignação sexual como para a bariátrica, o/a psicólogo/a foi solicitado pelo CFM como um profissional informante sobre a condição favorável ou não do/a paciente para operação solicitada (pelo próprio cliente ou pelo médico). Para muitos casos, é necessário pontuar o CID ou o DSM coincidente com a demanda ou o sintoma relatado. No entanto, é possível substituir as descrições psicológicas meramente psicopatológicas e, assim, pode-se traçar linhas de fuga, uma vez que é possível apontar outros aspectos psíquicos como as condições vulnerabilidade dos sujeitos.

Tais elementos se configuram como um dos analisadores da pesquisa, que precisou ser lido pela pesquisadora com distanciamento de suas próprias reflexões, para que as análises pudessem ser feitas. Trata-se de um recurso importante para a validação do método cartográfico: o acesso da/o pesquisadora/or à experiência investigada. Nesse sentido, por meio do olhar da pesquisadora sobre o contexto pesquisado e os discursos focalizados, foram observadas como as narrativas são discursivamente construídas e posicionadas, possibilitando, ao mesmo tempo, dispô-las sob o 
escrutínio de avaliadores/as para acessarem à experiência da pesquisa realizada.

Considerou-se como delineamento espacial desta pesquisa um processo de habitação de um território que se desenrolou por dois anos e meio. Assim, contou com o setting de atuação profissional da pesquisadora; a participação em cinco encontros no grupo de homens trans e dois encontros no coletivo de jovens LGBT, ambos da cidade de Brasília; e as entrevistas narrativas e episódicas com seis pessoas auto-denominadas transexuais, travesti ou trans não binárias/os.

\subsection{Quem são os sujeitos participantes da pesquisa?}

Foram considerados sujeitos participantes da pesquisa, a pesquisadora, seis pessoas trans (auto-denominadas/os binários e não-binários) jovens e adultos (dentro da faixa etária entre 21-50 anos), em entrevistas narrativas e episódicas com a pesquisadora.

Para as entrevistas individuais foram escolhidos/as aqueles que aceitaram a participar da pesquisa, tanto aqueles/as que já realizaram quanto os/as que estão prestes a realizar a cirurgia de redesignação sexual. Ou ainda que não fazem questão de qualquer cirurgia. Assim, foi entregue a cada um/a dos/as participantes da entrevista um Termo de Consentimento Livre e Esclarecido (TCLE) para que estivessem cientes dos objetivos, dos cuidados éticos, da minha proposta de tese (em alguns momentos, apresentei o próprio texto da qualificação) e, assim, declararam a concordância em participar. A quantidade de participantes se justificou, pois, tratou-se de uma pesquisa que visou se aprofundar na compreensão dos processos de constituição da subjetividade por meio da história de vida dos sujeitos, com foco no desenvolvimento e nos marcadores de trajetória.

\subsection{Como foi possível engajar o campo de pesquisa?}

Para cartografia, é necessário que a pesquisadora desenvolva a construção de determinadas estratégias para engajar o seu problema de pesquisa e traçar um plano coletivo e comum de participação entre os sujeitos (a pesquisadora e as/os participantes). Ou seja, torna-se importante delimitar o modo como engajou o seu campo problemático ou ainda colocar em evidência a maneira de como produziu com cada participante o envolvimento necessário para que estivessem à vontade para contar suas histórias de vida.

Realizar uma pesquisa com dois ou mais encontros é um desafio, pois o sujeito pode ou não querer aparecer no segundo ou no terceiro encontro, ou pode recusar a participar de antemão, as pessoas transgêneras, em geral, não têm se disponibilizado a colaborar com investigações realizadas por pessoas cisgêneras. Para elas/es, trata-se de um posicionamento político de não assujeitamento como objetos manipuláveis e de não subalternização de suas experiências, preferem compartilhar entre si suas vivências ou divulgar em redes sociais as suas práticas pessoais.

No primeiro momento de minha pesquisa, fui logo confrontada por ser uma mulher cisgênera que estava no grupo de mulheres trans para fazer a "coleta de meus dados" ou "pesquisar sobre a 
transexualidade" para fins estritamente pessoais. Elas compartilhavam entre si as suas particularidades. Foi o próprio campo que me disse como melhor agir, a partir de desencontros e encontros ou, ainda, de analisadores.

Aos poucos fui desenvolvendo um ethos de como elaborar o estudo. Havia um domínio inexplorado que o próprio campo me apontou. Nesse contexto, surgiu a possibilidade de fazer uma pesquisa com aquelas pessoas que estavam sendo deslocadas ou invisibilidades de vários contextos sociais. Além disso, foi possível habitar outros contextos da pesquisa como os grupos de movimentos sociais de homens trans e LGBT, ambos por meio de políticas da amizade. Assim, o contato entre a pesquisadora e os participantes mostrou-se convidativo e engajado ou desenvolveu-se a partir de uma implicação mútua.

\subsection{Dispositivos da pesquisa}

O conceito de dispositivo é um dos mais importantes desta pesquisa, por isso pode-se dizer que o ele envolveu diferentes níveis de caracterização e de delimitação. Durante o processo foi visto como uma espécie de manejo ao mesmo tempo instrumental, operacional e teórico-analítico; porém, com a indicação de diferentes entradas, sendo importante descrever cada uma delas.

Dentre os seus atributos instrumentais, é visto uma categoria de fácil acesso e apreensão, trata-se dos objetos utilizados durante a investigação (um gravador digital para registro e transcrição das entrevistas com os/as participantes, um diário de bordo para os demais procedimentos de observação e um roteiro da entrevista episódica e, por fim, o material transcrito). Após a transcrição feita pela própria pesquisadora, como uma tarefa de pré-análise, leu-se as entrevistas diversas e sucessivas vezes para conhecer intimamente e se familiarizar com o material, sempre com os objetivos em mente.

Dentre os atributos operacionais, pode ser considerado um pré-texto ou um disparador inicial, trata-se de cada um dos procedimentos da pesquisa. Tendo a intenção de trazer à tona elementos dispostos no campo de problematização para, logo em seguida, permitir o desenvolvimento em linhas analíticas. Foram considerados os procedimentos para a construção da pesquisa e para a posterior apreciação: as observações exploratórias com base no diário de campo da pesquisadora e as entrevistas narrativas e episódicas com seis pessoas.

Dentre os atributos teórico-analíticos, o dispositivo é o motor principal de geração de análises, pois, a partir do conceito de dispositivo da transexualidade, se propôs analisar como se constituem as práticas de subjetivação em experiências concretas. De acordo com o resultado gerado, visou um diagnóstico contemporâneo de regimes de verdade. O desdobramento de tal dispositivo se deu a partir da observação de três eixos de inovação considerados essenciais para este trabalho: explorar uma psicologia do desenvolvimento crítica e pós-estruturalista; a despatologização das experiências trans; ampliar a utilização da metodologia da cartografia na Psicologia, visando destacar uma perspectiva não-representacional de análise. 
A partir do trabalho com os dispositivos, surge dois outros elementos analíticos: os analisadores e os diagramas. Os analisadores são acontecimentos inesperados e altamente frutíferos para o trabalho, eles serão caracterizados na seção de resultados. Um dos analisadores citados neste texto foi o modo como o campo foi engajado por meio de políticas da amizade. Por outro lado, o diagrama é a operação interna ao sistema dos conceitos, isto é, traduz o modo como os conceitos atuam no texto, nesta tese, formam o diagrama de análise dos processos de subjetivação contemporâneos. Para exemplificar, a leitura de Deleuze, sobre Foucault (Deleuze, 2013c), pontua que enquanto o panóptico é um dispositivo de vigilância, construído na modernidade, e utilizado para almejar o controle dos corpos e dos indivíduos, a sociedade de controle é o diagrama de organização da sociedade atual.

\subsection{Procedimentos de construção e de análise das informações}

- Análise do diário de campo da pesquisadora:

As observações na pesquisa de campo foram realizadas mediante uma pista essencial da cartografia: o funcionamento da atenção do cartógrafo, em que atenção não se dá pela simples seleção das informações, mas é flutuante, concentrada e aberta. Durante o procedimento de pesquisa foi feita uma observação participante em contextos de socialização, mais especificamente, em encontros vinculados ao movimento social de homens trans e ao movimento social de jovens LGBT, como mencionado anteriormente. As observações serviram como meio de contextualização e inserção da cartógrafa em campo e fundamentaram as análises das entrevistas e a teorização do trabalho.

A fase exploratória para esta cartografia consistiu em um processo de habitação de um território ao mesmo tempo investigativo e existencial. Além disso, envolveu a consciência da pesquisadora acerca das tecnológicas metodológicas que precisavam ser desenvolvidas. O campo problemático foi se formando na fase exploratória, sendo possível traçar os procedimentos (os dispositivos operacionais) utilizados. Tratou-se de um processo de sondagem, com vistas a elaborar as ideias e construir, posteriormente, as hipóteses da pesquisa. As estratégias usadas atuam como implicação que diz respeito a descrever as relações da/o pesquisadora/or e de seu pesquisar. Por isso, foram feitas análises de implicações (Barros \& Barros, 2014) do meu processo como pesquisadora baseadas no meu diário de campo, com a identificação dos analisadores que se processaram durante a pesquisa.

- Análise das entrevistas narrativas e episódicas:

No contexto dessa cartografia, a entrevista é considerada um contexto essencial de negociação e produção de sentido, por isso exige do entrevistador, sobretudo, uma postura de escuta ao que é inédito: "uma entrevista poderia ser o traçado de um devir" (Deleuze \& Parnet, 2013). Por 
isso, em geral, mantinha-me em silêncio a fim de ouvir as suas narrativas e, em momentos específicos, introduzia questões do roteiro previamente elaborado ou a partir de perguntas que surgiam no próprio contexto da interação ${ }^{46}$ (Tedesco, Sade \& Caliman, 2014), tendo em vista o andamento da conversa.

A entrevista instaura uma questão capaz de atravessar a subjetividade do/a entrevistador/a e daquele que é entrevistado/a. "Ao fazer uso das entrevistas, interessa à cartografia promover o acesso ao plano coletivo de forças e de sua indeterminação, a pluralidade de vozes na experiência compartilhada de dizer" (Tedesco, Sade \& Caliman, 2014, p. 123).

Diante disso, para atender aos objetivos específicos do presente estudo, realizou-se um método de entrevistas em profundidade mediante vários encontros. Foram realizadas entrevistas narrativas individuais com seis pessoas trans jovens ou adultos/as, com duração entre 40 a 70 minutos cada (em local público, tranquilo e confortável ao/à entrevistado/a, previamente combinado), totalizando treze horas de material em áudio. É importante considerar que a quantidade de entrevistas não foi padronizada, pois teve situações em que o/a participante se disponibilizou aos três encontros, outros a dois, e teve um entrevistado que só quis participar de uma sessão. Em cartografia, não se trabalha com descarte de participantes que não conformam o padrão da pesquisa, todo material é analisado e os desencontros do próprio campo são vistos como acontecimentos inesperados ou analisadores.

Assim, as entrevistas foram divididas em dois momentos principais (foi o que aconteceu com quatro dos/as participantes): no primeiro, foi realizada uma entrevista aberta individual em que se privilegiou a narrativa livre do/a participante; no segundo, realizou-se a entrevista episódica em que a pesquisadora retomou alguns eventos narrados na primeira sessão a partir de conversas; e, por fim, o que aconteceu em apenas um caso, o terceiro encontro foi marcado por uma conversa em que o/a participante levou fotografias de sua infância, adolescência e idade adulta.

A entrevista narrativa foi escolhida, pois se aproxima da autobiografia, consistindo no ato de narrar o próprio desenvolvimento. As entrevistas episódicas foram utilizadas para investigar os processos de identificação construídos em suas históricas. Enquanto a entrevista narrativa aprofunda a narrativa biográfica, as detalhadas estão relacionadas às situações da entrevista episódica. Segundo (Flick, 2000), "o conhecimento episódico se organiza acerca das experiências e se associa a situações e a circunstâncias concretas" (p. 114), é o momento segundo o qual a/o entrevistada/o dedica atenção especial às situações ou aos episódios que tem vivenciado.

As análises foram feitas com base nos dispositivos construídos ao longo da cartografia.

46 Para Tedesco, Sade e Caliman (2014), "na cartografia, a escuta acompanha a processualidade do relato, a experiência em cuja base não há um eu, mas, sobretudo, linhas intensivas, fragmentos de sensações, sempre em vias de constituir novas formações subjetivas. Neste sentido, a entrevista se aproxima de uma conversa. Usando a distinção sugerida por Deleuze e Parnet (2013), não como uma conversação entre sujeitos preestabelecidos, mas como uma conversa que procede por intersecções, cruzamentos de linhas, agenciamentos coletivos de enunciação" (p. 109-110). 
Como já mencionado, os dispositivos estão relacionados com a atividade de produção da pesquisa e, por isso, possibilitaram observar as relações dos processos de subjetivação inseridos as narrativas dos participantes. Nesse sentido, das narrativas dos/as participantes, extraiu-se a sutileza de argumentações singulares, posicionando-as de modo destacado para produzir vários eixos de análise. A ideia que aparece na cartografia é a da não universalização do caso pesquisado, visto que se dá no âmbito da experiência de cada sujeito. Trata-se do cerne das elaborações teóricas desenvolvidos anteriormente.

Para a análise do diário de bordo e das entrevistas, foram citados trechos de fala, por entender que se trata de analisadores situados como acontecimentos (Lourau, 1993), além disso, eles podem ser "auto-enunciativos, na medida em que ocorrem, chegando até dispensar interpretações posteriores" (Hur, 2009, p. 199).

A fim de proceder uma perspectiva não-representacional de análise, recorreu-se a concepção de linguagem de Deleuze/Guattari (2011) e Bakhtin (2010; 2011; Brait, 2014). Segundo a pragmática desenvolvida pelos autores, foi possível conceber análises processuais, levando-se em conta três dimensões importantes: a produção de sentidos, que são mais dinâmicas, ambivalentes e depende do contexto da interação social; de outro modo, o significado tem uma dimensão estrutural e estática, que tem a ver com os regimes de enunciação, ou seja, com regimes de verdade culturalmente negociados (neste contexto, entende-se que existem estratégias usadas para manter um regime de enunciação linguístico como verdadeiro); por fim, o papel da autora-pesquisadora nas suas análises é ativo, pois tende a imprimir a sua leitura e sua voz nos "dados". Segundo tal parâmetro, é possível dizer que não existe neutralidade durante a produção e análise das informações. 


\section{RESULTADOS E DISCUSSÃO \\ Os resultados do experimento ou as imagens da experiência}

A organização e a tessitura das ideias realizadas até o momento permitiram situar um modo particular de ler a experiência da pesquisa propriamente dita. Durante o percurso, a cartógrafa teve o cuidado de indicar quais seriam as estratégias utilizadas e ainda apontou uma dada possibilidade de análise do próprio fazer científico, com o desenvolvimento de uma narrativa sobre a produção de subjetividades no contemporâneo.

Diante disso, a política de escrita escolhida passou a ser uma técnica segundo a qual se pôde evocar uma crítica a métodos representacionais de investigação e, por isso, permitiu o desenho de novos mapas. Entende-se que produzir mapas envolve o delineamento de elementos processuais na formação do campo problemático, esses são contingentes entre si e próprios à prática da pesquisa. Em cartografia, por exemplo, é importante questionar para que serve delimitar um momento específico apenas para a análise dos resultados, se esta atravessa todo o trajeto da investigação e, consequentemente, há uma abertura de zonas de implicações entre a pesquisadora e o seu pesquisar durante a construção de cada um dos dispositivos. Na tentativa de traçar uma resposta para essa problemática $^{47}$, a discussão metodológica tem sido tratada de modo transversal em todas as seções.

A proposta a ser desenvolvida emerge de uma articulação entre o que poderia ser os resultados de experimentos com seres humanos ou as imagens que poderiam apresentar a experiência da pesquisadora e dos/as participantes, no traçado de um plano comum. Trata-se de uma importante discussão sobre o que significa fazer ciência com a cartografia. Em psicologia, implica avaliar com criticidade o papel de pesquisadoras/es, engajar uma prática de pesquisa politicamente implicada e colocar em xeque modelos representacionais de investigação e de análise dos resultados, para sugerir outras alternativas. Por conseguinte, elaborar uma possibilidade inovadora se configurou como a intenção essencial deste trabalho.

Deleuze (2015) faz uma crítica ao ponto de vista da representação em ciência mediante a perspectiva da "produção de sentidos". O "sentido" gira em todas as direções, permitindo que o processo de experimentação se desloque do idêntico (plano de representação) para o problemático (plano do acontecimento). Essa função criativa e produtora permite traçar o sentido não como uma propriedade original de algo, podendo-se separar de seu suporte empírico e problematizar a própria capacidade genética da produção de sentidos. É necessário desenvolver uma lógica do acontecimento que coloca em questão uma mudança em relação ao sentido. Não se trata do problema de interpretar

47 É uma exigência do Programa de Pós-graduação em Processos de Desenvolvimento Humano e Saúde (PGPDS) apresentar a escrita da tese em seções designadas: introdução, fundamentação teórica, método, resultados e análises. Também tem sido uma exigência histórica de muitos periódicos científicos em Psicologia internacionais e nacionais. 
a origem, mas de evocar uma gênese, pois não se objetiva uma "regra de soluções", mas a possibilidade do germinar de seu poder genético, o seu poder de constituição de um campo de problematização (Deleuze, 2015).

Se o/a pesquisador/a examina as informações com rigor, recorta-as em unidades de análise e, a partir delas, atribui um significado a expressões ou a sentenças escolhidas por ele/a (independentemente se o método é quanti ou quali), é possível que ele/a imprima a sua "voz" nos dados. Ou seja, durante o procedimento, coloca em evidência o que elege como elemento principal para sua observação. Em potencial, existem várias construções analíticas para um dado texto e as interpretações tendem a ser diversas, uma vez que dependem da subjetividade de um/a determinado leitor/a para lhes dar sentido. Geralmente, o/a investigador/a acredita na neutralidade do seu fazer científico e se propõe a sistematizar e a atribuir significados específicos aos "dados coletados". Porém, é possível dizer, de forma provocativa, que ele/a pode não estar somente interpretando, mas os modificando ou transformando-os.

Segundo Deleuze (2015), “interpretar” é criar um novo sentido e observar o que está por atrás do que está sendo observado. Nas pesquisas interpretativas com sistemas de informação, há sempre uma categorização que visa dar legitimidade aos resultados. Até então, interpretar consiste em estabelecer relações entre os eventos, sendo possível descrevê-los para descobrir o significado desse algo. Os/as matemáticos/as criam sistemas com linguagens específicas para descrever os objetos ou a relação entre objetos, por isso entendem a realidade como um processo em curso e, dessa forma, objetivam mais descrever e explicar do que interpretar (Passos, Kastrup, \& Tedesco, 2014).

Diante disso, a cartografia assume o fator "subjetividade" na leitura do/a pesquisador/a aos dados (como no que ocorre sob o "erro de paralaxe") e, por isso, não pretende negá-la ou ocultá-la. Dessa forma, evidencia que o processo de análise não se faz com o "interpretar", mas se dá de outra maneira, por meio da criação de uma outra narrativa, a partir da descrição de como os eventos acontecem e se desenrolam. Por isso, "descrever" mais do que "interpretar" pode dar sentido as relações da/o pesquisadora/r com o seu pesquisar, ainda podem mobilizar a processualidade e o campo de forças da respectiva investigação.

Diz-se, portanto, que, em cartografia, a intepretação ocorre por meio de processo de tradução. A escuta ao campo e aos dados é a de uma tradução ou a de uma travessia da experiência, o que vai sempre implicar um desvio de sentido (Passos, Kastrup \& Tedesco, 2014). Há, então, uma transformação do que se quer conhecer mediante o contato da/o pesquisadora/r com o campo, sendo que durante a tradução ocorre a criação de algo novo e a/o cartógrafa/o utiliza a inventividade a seu favor. Nesse sentido, compreende-se a importância de desenvolver estratégias de processualidade coerentes às políticas de escrita e consistentes à toda a pesquisa e, além disso, é importante observar o seu campo de forças. A partir daí, é possível avaliar se o processo de "tradução" dos resultados foi desempenhado com rigor. 
Traduzir é realizar a passagem de uma língua a outra, sem que haja uma língua por trás, que pudesse funcionar como um ponto de vista externo, garantido ou afastado. Estamos sempre numa língua ou noutra, não há uma língua por trás que constitua um solo seguro que garanta a passagem de uma a outra (...). Não podemos contar com invariantes que nos abririam para uma universalidade supostamente dada. Temos, ao contrário, que encontrar ou produzir equivalentes. Nos termos da pesquisa cartográfica, a equivalência produzida não é sinônimo de correspondência, mas se dá como sintonia no plano das forças (Kastrup \& Passos, 2014, p. 274).

Para a cartografia, a ciência é vista como uma prática realizada por cientistas, por isso a discussão metodológica tem sido tratada de modo transversal ao texto. Sair da zona de conforto oferecida pelo modelo da representação não tem sido uma tarefa fácil, por outro lado, entende-se que "pesquisar é acompanhar processos e não representar mundos" (Barros \& Kastrup, 2015). Assim, tem sido construída uma oficina de pesquisa inventiva baseada na dimensão singular da experiência. Durante a construção da oficina, houve o desenvolvimento de um ethos próprio de se fazer pesquisa e as estratégias utilizadas aqui podem ou não funcionar para outros contextos, ou seja, esta pesquisa não visa em hipótese alguma a sua replicação. Uma vez que um determinado território, antes não conhecido, foi habitado, o campo traduziu a/o pesquisadora/r de um determinado modo e a pesquisadora precisou se envolver em políticas da amizade.

Estas se efetuaram mediante a construção de um mundo comum e heterogêneo em que foi produzido efeitos de transformação da experiência. Nesse sentido, foi possível refletir sobre a possibilidade de inventar novos mundos para traduzir as relações entre singularidades e não entre identidades prévias ou já constituídas.

Após todo percurso realizado, pode-se trazer novamente o conceito de dobra para mobilizar os campos de força da pesquisa. O intuito é avaliar quais as estratégias de resistência poderiam ser utilizadas quando estamos situadas/os num mundo em que só se faz e fala do mesmo, ou seja, da manutenção de normas e lógicas baseadas em privilégios. Ao ser possível colocar em análise tanto um território existencial quanto o processo de intervenção sobre esse território, há a possibilidade do conceito de dobra sugerir um mundo como potência criadora e é por meio dela é que o novo se produz (Deleuze, 2013c).

Por meio de diferentes ângulos ou pontos de visibilidade, a imagem da dobra informa a relação do sujeito consigo, com o outro e com o mundo, simultaneamente. Desse modo, evidencia as relações e as contingências entre acontecimentos e as singularidades que marcam os processos de produção da subjetividade em seus macros ou microníveis de análise. Assim, observa-se as circunstâncias de formação das práticas de subjetivação contemporâneas, para saber quem somos e que período e mundo são estes no qual estamos vivendo, a fim de criarmos novos sentidos e outros modos de vida.

Esta seção de análise será composta por dois momentos: no primeiro, aparece a análise de implicações e avaliação de efeitos, em que serão apresentados os analisadores da pesquisa; no segundo, compõe-se a cartografia dos processos de subjetivação com as narrativas das/os 
participantes, a fim de defender relação dinâmica e não linear entre memória e narrativa, e com as análises gerais dos resultados a partir de minhas contribuições e inovações teóricas, nomeada "desenvolvimento, gênero e processos de subjetivação".

\subsection{Análise de implicações e avaliação de efeitos}

Neste trabalho, a operação de cada um dos dispositivos escolhidos e apresentados na seção oficina da pesquisa permitem observar as racionalidades que os compõe. O próprio dispositivo da transexualidade tem possibilitado observar as racionalidades presentes em determinados discursos ou em práticas extra-discursivas, como nas práticas de si em experiências trans.

Ao longo da pesquisa de campo, apareceram alguns analisadores como resultados da operação dos dispositivos, por isso a ideia é a avaliar os efeitos produzidos. Nesse sentido, os analisadores trouxeram o registro de problematizações essenciais quando a pesquisadora começou a habitar um território antes não conhecido e ainda levantou hipóteses sobre como poderia engajar o seu campo de pesquisa, por isso são apresentados os analisadores do diário de bordo e da prática de pesquisa.

\section{Análise de implicações e avaliação de efeitos do diário de bordo da pesquisadora}

O diário de campo foi utilizado como orientação e apoio ao trabalho de campo da pesquisa, uma vez que apresentou marcadores com base em registros que delineavam a trajetória da cartógrafa e indicavam pistas conforme os acontecimentos ocorriam. Tomado como um dispositivo, fez operar ligações entre os signos temporais, espaciais (contexto) e afetivos. É relevante destacar que o registro precisa envolver tanto o que é pesquisado como o processo do pesquisar.

Os registros fazem surgir uma determinada política da escrita. Assim, possibilitam a análise das implicações da cartógrafa, que se entrelaçam durante o trabalho, por isso apresenta a função de ser um disparador de desdobramentos da investigação (Lourau, 1993). A partir de um olhar sobre a experiência, a própria cartografia requer o desenvolvimento de uma narrativa, que permitiu a elaboração de registros com base nas impressões da pesquisadora feitas durante o período da pesquisa. A política de escrita do diário a ser apresentado permitiu a construção de uma nova narratividade e indicou os efeitos, ou seja, os analisadores da própria prática da pesquisa. Serão apresentadas as memórias da cartógrafa e, em seguida, as respectivas análises, que foi intitulada como a pesquisadora-participante na cartografia.

\section{a. As memórias da cartógrafa}

Neste momento, será apresentada uma seleção de memórias escolhida pela própria 
pesquisadora. Elas se referem a momentos anteriores às entrevistas com os sujeitos e estão relacionadas a forma de como o campo começou a ser habitado. Apresentar algumas recordações permite contextualizar e apontar os momentos em que os "acontecimentos singulares" da investigação surgiram e ainda como se manifestaram. Por isso, o papel das memórias é colocar visibilidade nas linhas de força da pesquisa, a partir dos analisadores contidos dispositivos (diário de campo e entrevistas narrativas e episódicas com cada um dos participantes).

Dessa forma, evidencia e realça elementos essenciais com os quais pretendeu argumentar como as práticas de resistência em processos de subjetivação de experiências trans. No contexto deste trabalho, as anotações da cartógrafa podem indicar acontecimentos singulares. Assim, a função de referência, situada no diário, cria territórios e contornos necessários à investigação, é possível perceber elementos que assinalam a orientação de sentidos.

Antes de apresentar as memórias, torna-se importante situar quais os analisadores podem surgir delas, sendo nomeados, neste contexto, como: a pesquisadora-participante na cartografia, políticas da amizade na prática de pesquisa com pessoas trans e as linhas de visibilidade do TCLE (Termo de Consentimento Livre e Esclarecido).

\section{Entrando em campo: negociação de territórios}

\section{Escrito 01: ser interpelada como cisgênera}

Ultimamente, as pessoas (muitas, cisgêneras) de fora do contexto da pesquisa têm me perguntado o porquê escolhi estudar práticas de subjetivação de experiências trans, se eu sou uma pessoa cisgênera. Ou ainda, qual a minha intenção senão pertenço a nenhum grupo LGBT. As pessoas também questionam sobre a minha sexualidade.

\section{Escrito 02: primeiro contato}

Ontem fui ao Seminário Internacional de Direitos Humanos em Brasília. Participei como ouvinte de uma roda de discussão sobre os direitos das pessoas LGBT. Foi o meu primeiro contato com pessoas auto-denominadas trans. No final da roda de conversa, fui conversar com as pessoas (os homens trans da mesa) mais diretamente. Trocamos contatos e conversas informais. Houve um encontro bem amistoso.

\section{Escrito 03: a instituição hospitalar e seus discursos}

Primeira visita à instituição visada para a investigação segundo o projeto e o planejamento realizados. $O$ primeiro contato foi feito com a psicóloga responsável pelo atendimento às pessoas trans. Foi feita uma observação inicial. Os discursos da profissional atuavam de modo a facilitar a entrada dalo transexual no sistema de saúde, não existe uma rede profissional de assistência multiprofissional na instituição observada, mas indicações de profissionais "disponiveis" a atender a questão trans fora do contexto. Foi passada uma impressão de uma precariedade do serviço multiprofissional da instituição (mas não digo da profissional, pois era capacitada para a escuta das especificidades dessa experiência), $e$ uma perspectiva de patologização, inclusive, no próprio discurso das pessoas trans, devido ao fato de o grupo ser conduzido no próprio contexto hospitalar. 
Escrito 04: os incômodos da pesquisa

Antes de apresentar o meu interesse de pesquisa para o grupo, conduzido por um sexólogo, fui confrontada pelas participantes (mulheres trans). Elas logo disseram que não gostariam de participar da investigação, pois houve pesquisadores/as que foram fazer as suas procuras no referido contexto e nunca voltaram a fim de realizar a devolução de seus resultados. Definitivamente, isso me fez pensar em como engajar o meu campo de pesquisa, como fazêlo "acontecer" para que os sujeitos se sentissem interessados ou ainda valorizados ao compartilhar suas vivências para o meu doutorado. Posso dizer que o fato de ter sido questionada e o imediato confronto produziram efeitos sobre o desenvolvimento de meu ethos como pesquisadora. Posso dizer também que me senti desconfortável, foi o primeiro momento da minha vida acadêmica que, de fato, um sujeito de pesquisa tinha se recusado. Mas havia um incômodo tanto meu quanto das pessoas "investigadas" que deveria ser levado em consideração.

\section{Escrito 05: os homens trans}

Percebi, a partir do contexto anterior e durante o processo de habitação do território, que os homens trans, em particular, trocam informações em redes virtuais sobre atendimento multiprofissional capacitados e especializados às suas demandas. Percebi que não existe profissionais especializados a uma escuta diferenciada. Há um/a ou outro/a endocrinologista, cirurgião/ã plástico/a, psicólogo/a; não existe assistência profissional especializada sobre o que seria um híbrido entre um ginecologista ou urologista.

\section{Escrito 06: o corpo errado}

A partir da minha experiência prática e escuta ao campo, observei a possibilidade de existir um preconceito internalizado que os fazem se sentirem "no corpo errado", será a sociedade que fabrica esse corpo mutilado? Errático? E retira a pluralidade de sua vida? As pessoas têm medo de serem descobertas pelo que elas são ou sentem ser, tanto em relação à sexualidade quanto à identidade de gênero. Não é uma vida fácil, precisam de uma escuta que os compreendam pelo o que são e estão sujeitos às violências brutais, pautados pela transfobia.

\section{Territórios em transição}

\section{Escrito 07: as experiências trans}

Em mais um dia de habitação ao território da pesquisa, tenho percebido falas importantes das pessoas: "quando era criança me entendia como menino, quando me tornei adolescente já não sabia mais quem era". "Gostaria que minha identidade de gênero estivesse em consonância com meu corpo". Em relatos feitos por várias pessoas, há uma tentativa de negociação sobre o uso de roupas masculinas desde a infância e sobre uso gêneros para se referir a si mesmo e aos outros. As pessoas trans se comunicam pela internet e pelo whatsapp e fazem uma rede de cuidados entre eles, são muito bem informadas sobre leis e conceitos. A narrativa de João W. Nery, para saber como se definir (como transhomem? homem trans? homem?), tem sido um marco histórico-social muito relevante. Em geral, há algo na cultura e na experiência do outro que fala sobre a história de vida de uma pessoa singular (identifica-se e se posiciona).

Escrito 08: O que as pessoas trans tem a dizer para o direito e a psicologia?

Encontro sobre nome social para as pessoas transexuais, transgêneras, travestis e intersexuais do DF. Há pessoas cisgêneras como profissionais do campo do Direito, da Saúde e pessoas transgêneras, que abordam seus relatos de vida. Falam sobre constrangimentos cotidianos em relação ao nome social. A identidade com o nome 
designado ao nascer tem sido um documento que não os representa, tanto no que diz respeito ao nome quanto ao gênero e visam, por meio da justiça, um processo de retificação nos documentos mais célere. Há ainda uma demanda de uma ampliação do debate para toda a sociedade que vislumbre o respeito à dignidade humana. Existem falas como: "quando o meu nome chegou, eu nasci de novo (emoção): nome que você merece, e o que você é"; "sou homem trans pansexual". "Na transição, a gente não tem tanta auto-estima". "Há uma preocupação com a imagem que passa para a sociedade". Sobre os laudos comentam: "Não é todo mundo que tem todos os atendimentos e um laudo, mas, uma vez que, nele está a nossa dignidade, precisamos questionar isso. Há muitos psicólogas/os que não conhecem a experiência trans, por isso é necessária a revisão do processo diagnóstico". (...) "Existe a questão do suicídio e da mutilação corporal, quando não tem a aparência masculina suficiente. Além disso, não tem demanda médica para homens trans". Sobre as práticas de si como resistência: "Se não formos atrás dos nossos direitos, eles não acontecem". "Até poucos anos atrás não se ouvia falar em transexualidade, e tive que, em muitos momentos, viver uma vida dupla". "Ser uma mulher trans e ao mesmo tempo ser representada pelo feminismo". "Há ainda as pessoas trans não binárias que visam a sua dignidade". "Precisamos de um Estado verdadeiramente laico".

\section{Escrito 09: resistência à patologização da experiência}

Encontro sobre nome social, segundo dia. Outras vozes apareceram e a questão do laudo psicossocial continuou sendo um foco importante de discussão. Talvez esse seja o principal foco de resistência "a despatologização das identidades trans" e o papel do relatório psicológico. E assim, questionam: "sobre o relatório psicossocial, porque o juiz se sente amparado com esse relatório? No contexto do atendimento, reescrevemos o laudo com o profissional que está nos atendendo". Fala da psicóloga na mesa, "com o nosso saber e posição enquanto profissional, elaboramos um relatório para saber se podemos contribuir. Ouvimos e resumimos o que foi falado pelo cliente. Há um saber-poder da própria experiência, mas também há a possibilidade de onipotência do saber do profissional". Atualmente o atendimento psicológico tem sido feito em seções psicossociais de órgãos públicos diferentes e em contextos de atendimentos clínicos privados. $E$ importante questionar como tem sido feito o acompanhamento. Há outra crítica de outra pessoa trans na mesa quanto ao processo de retificação de nome nos documentos: "Há uma violência psicológica quando cerca o direito do outro, ser da forma como você se identifica".

\section{Escrito 10: Luta pelos direitos humanos: resultados como promessas ou práticas efetivas?}

Atualmente tem sido feito encaminhamentos para a melhoria de direitos da população trans no Distrito Federal (DF) quanto ao nome social devido à visibilidade e à luta do movimento trans. Segundo relatos, tem sido fomentado pelo Governo do Distrito Federal um programa para a erradicação da LGBTfobia. Precisamos observar se tem sido colocado em prática.

\section{Escrito 11: As novas expressões de gênero e de sexualidade}

Nos dois encontros no coletivo de jovens LGBT percebi um movimento engajado e bem organizado entre eles. São promovidas palestras para a comunidade em geral e universitária. Os jovens estão utilizando outras expressões corporais e outras linguagens de gênero. Há um terceiro, quarto ou quinto jeito de se expressar, existem pessoas que se (auto)denominam como trans não-binárias, travestis, bigêneras, agêneras. Existe uma outra tentativa para ocupar o espaço público fora dos regimes de inteligibilidade prévios. As novas expressões de identidades de gênero têm se apresentado de forma mais fluidas. Há um potencial político no questionamento das normas binárias de gênero ou no que significa ser mulher (cis), homem (cis), mulher (trans) ou homem (trans), o que é ser feminino ou masculino. Expande-se as fronteiras. 
Escrito 12: As políticas da amizade nas entrevistas

Só foi possivel iniciar as entrevistas com os/as participantes quando houve uma sintonia, que é próximo ao conceito de simpatia como agência, em Deleuze. Em geral, as pessoas transgêneras não tem se disponibilizado a participar em pesquisas com cisgêneros/as. É uma forma de resistência a serem tratados como objetos de pesquisa. Assim, só foi possível fazer as entrevistas, inclusive nas de mais de um encontro, porque houve uma agência da pesquisadora com o campo de investigação mediante políticas da amizade. Só assim foi possivel habitar o campo das entrevistas.

\section{b. A pesquisadora-participante da cartografia}

Neste momento, são apresentadas as discussões referentes aos escritos, ou seja, às memórias. Na cartografia (Kastrup, Passos \& Tedesco, 2014), a presente pesquisadora pode ser considerada uma participante de sua própria investigação, sendo necessário conceber uma análise de implicações com a avaliação dos efeitos produzidos pela sua prática de pesquisa. É relevante observar que "o pesquisador é o analista e não o analisador (...) somente os analisadores o constituem como analista, que não pode subtrair os efeitos analisadores do dispositivo de intervenção" (Barros \& Barros, 2014, p. 179). As estratégias utilizadas foram conduzidas de acordo com diferentes implicações da pesquisa com o campo, por isso tem sido relevante descrever as relações da pesquisadora com o seu pesquisar, sendo possível identificar quais os analisadores se processaram durante a condução dos procedimentos.

A leitura do diário de campo possibilita observar os elementos essenciais da temática que se pretendeu investigar com base nos objetivos definidos durante o percurso. Além disso, para a cartografia, a proposta "da análise é validar o analisador" (Barros \& Barros, 2014, p. 179), consequentemente, constata-se que a chave é manter uma processualidade da discussão em forma de resultados provisórios: "o que move a análise em cartografia, portanto, são problemas. É a um problema que ela se volta e são também problemas o seu resultado. (...) Analisar é, assim, um procedimento de multiplicação de sentidos e inaugurador de novos problemas" (Barros \& Barros, 2014, p. 178). Por meio do olhar da pesquisadora sobre o contexto pesquisado e os discursos focalizados, estudou-se como as narrativas foram sendo produzidas pelos participantes na medida que se manifestavam.

Tem-se como ponto de partida identificar qual é a função do conceito de memória utilizado na fundamentação teórica e o que diz sobre implicação da pesquisadora no seu próprio campo. As memórias da cartógrafa têm uma função de atualizar o passado vivido e de sempre ressoá-lo sobre o tempo presente e sobre o porvir da experiência, por isso optou-se por não fazer marcações temporais específicas. Habitar diversos campos, a prática como psicóloga, o movimento social e encontros com os participantes em entrevistas, possibilitou um engajamento ético e político da pesquisadora, uma vez que se tornou sujeito de sua própria investigação. Assim, pôde propiciar a cartografia de um 
território existencial, com o delineamento de práticas que se efetuavam pela transgressão às hegemonias.

É possível avaliar efeitos gerados em meus próprios processos de subjetivação como pesquisadora, que se referem à análise de implicações. Tais elementos fazem elo e revelam sentidos. No início, a minha atenção enquanto cartógrafa passeava entre os elementos dispostos no campo de pesquisa. O encontro com o problema de pesquisa foi um desafio produtivo, sendo que, ao mesmo tempo, foi possível conceber um saber-fazer engajado. $\mathrm{O}$ interesse em oferecer uma escuta diferenciada, a partir do que o próprio campo me dizia ou tensionava, revelou-se essencial. Foi se consolidando, cada vez mais, a importância de que meu trabalho pudesse propiciar um espaço de atuação e de reflexão para uma das atuais demandas contemporâneas do movimento trans, que é a da despatologização de suas experiências.

Uma vez que uma pesquisa com cartografia implica habitar um território, foi necessário um aprendizado da cartógrafa para cultivar a experiência e não se colocar numa posição de neutralidade sobre esta (Alvarez \& Passos, 2009). A relação direta com a vivência de pessoas trans me ofereceu suporte para saber o que e como pesquisar a produção de subjetividades, no que tange ao gênero e à sexualidade, a partir de experiências concretas. As reflexões desenvolvidas sobre os processos de subjetivação em experiência trans partiram desse profícuo contato.

As implicações da pesquisadora nesse território, ao mesmo tempo investigativo e existencial, envolveram traduzir a experiência investigada com o participar, o conhecer, o intervir e, assim, houve possibilidade de construção de outras formas de sociabilidade, em políticas da amizade. E, por isso, se buscou reconhecer a necessidade da criação e da efetivação de políticas públicas em respeito à plasticidade das expressões de gênero e de sexualidade, articulada aos seus processos de subjetivação. A minha formação enquanto cartógrafa implicou também em outros modos de narrar processos de produção da subjetividade em relação ao gênero, consoante leituras mais flexíveis sobre o devir humano na contemporaneidade.

Um acontecimento importante para a análise se refere as primeiras recusas à participação de minha pesquisa. Essas foram vistas como uma possibilidade de práticas de transgressão às pesquisas hegemônicas conduzidas por pessoas cisgêneras. "É importante pensar esse desconforto como inquietação, postergando uma avaliação que tente a caracterizá-lo como problema. Tratá-lo como dúvida, que pode fazer emergir outras linhas destoantes, tensionadoras, inquietas" (Sade, Ferraz \& Rocha, 2014, p.79).

No entanto, para a cartografia, as recusas são vistas como analisadores, também designado, para Latour (2000), como a recalcitrância da pesquisa. Esta significa a possibilidade de que as/os participantes de pesquisa têm de resistir ao que tem sido historicamente enunciado sobre elas/es, por sua vez, proclamam, a partir dos saberes sobre suas próprias experiências, a tessitura de novas problematizações no âmbito da produção científica ou social. "Nas pesquisas com humanos, a relação com a recalcitrância não é apenas epistemológica, relativa aos modos de conhecer, mas 
também ética, relativo ao reconhecimento e à valorização da experiência do outro" (Sade, Ferraz \& Rocha, 2014, p. 79).

Então, a recalcitrância diz respeito a um engajamento ético e político da pesquisa e, assim, foi necessário criar táticas específicas de como conduzir o campo. No contexto deste trabalho, lançou-se questões estratégicas como pontos de partida: num primeiro momento, a perspectiva do entrevistado para a pesquisadora: "qual a intenção desta pesquisa? O que ela tem a me oferecer?"; num segundo, com a ótica da pesquisadora para o seu campo: "qual é o meu objetivo com essa pesquisa? Qual é a minha proposta diferenciada para o campo?" Se colocar como sujeito e participante é também poder traçar um plano comum da experiência cartográfica e o seu resultado é o de co-implicação. Uma vez que a proposta compartilhada da pesquisadora e dos/as participantes era pela despatologização de processos de produção de subjetividades, houve a abertura de uma zona de interesses. Por isso, foi importante colocar em análise a resistência dos participantes trans aos padrões de um determinado fazer científico em psicologia ou, ainda, às pesquisas que visam retroalimentar às normas de gênero hegemônicas e, consequentemente, às relações de poder e de privilégio social.

As interrogações que o movimento trans tem trazido para a psicologia e sobre como produzir o relatório psicossocial é de suma importância, pois envolvem a dimensão de sua obrigatoriamente e psicopatologização da experiência, ou seja, existem jogos de poderes imbricados nessa relação. Por sua vez, no contexto hospitalar, as atuações das/os profissionais se restringem às práticas de socialização e aos discursos vinculados, em geral, ao processo transexualizador. No entanto, a escuta clínica pode ser viável quando estiver pautada pela promoção da saúde psicológica devido à vulnerabilidade e ao mal-estar psicossocial a que as pessoas estão sujeitas. Uma vez condizente com o respeito à diversidade de expressões de gênero e de sexualidades, esse pode ser um importante parâmetro no que tange à atuação de psicólogos/as para atendimentos clínicos ou psicossociais.

Assim, a partir de ideias de Foucault apontadas anteriormente, tecer um diagnóstico contemporâneo dos regimes de verdade colocaria em xeque o fazer ciência psicológica com neutralidade. Pode-se dizer, nesse sentido, que o dispositivo da transexualidade (Benjamin, 2006; Money, 1969; Stoller, 2006) foi culturalmente construído com base em estratégias linguísticas, uma vez que esteve fundamentado em regimes de enunciação vistos como verdades. O conceito de "transexual verdadeiro" (Benjamin, 1966; 1999) é uma prova disso, pois foi forjado dentro de um sistema de inteligibilidade científica. Por sua vez, esta análise poderia sugerir sobre como as práticas de subjetivação, em experiência trans, têm sido produzidas em políticas de amizade ${ }^{48}$ mediante novas relações sociais que marcam o atual espaço-tempo. A estilística da existência compreende práticas culturais diferentes, alianças políticas alternativas e outras formas de relação consigo mesmo e seus próprios corpos, bem como outros modos de vida possíveis (Halberstam, 2005).

$48 \quad$ Esse analisador será apresentado mais adiante. 


\section{Análise de implicações e avaliação da prática de pesquisa: a confiança na/o pesquisadora/or}

A partir das linhas de visibilidade observadas nas memórias apresentadas da cartógrafa, foi possível indicar um importante componente da pesquisa, a confiança dos participantes na pesquisadora e, assim, foram especificados os analisadores contidos no dispositivo entrevista. Estes podem engajar e operar o campo de forças da pesquisa de determinado modo, por isso um determinado manejo do dispositivo entrevista pode fazer com que os vínculos entre os participantes se articulem e produzam uma zona de confiança. Assim, "é possível construir dispositivos que reconheçam a experiência do outro, que contribuam para a emergência de novas subjetividades, de novas possibilidades de ação e de conexão com o mundo" (Sade, Ferraz \& Rocha, 2014, p. 68).

$\mathrm{O}$ modo de fazer pesquisa com a cartografia implica práticas de pesquisa com base em um processo coletivo de produção do conhecimento. O plano comum precisa ser construído e, por isso, demanda o desenvolvimento estratégias, como já foi mencionado anteriormente. Trata-se de um elemento ético em conexão com o aspecto metodológico que opera o coletivo de forças da pesquisa. "A aposta é que a confiança na experiência implica a promoção de uma experiência compartilhada que amplia a nossa potência de agir" (Sade, Ferraz \& Rocha, 2014, p. 69). Desse modo, torna-se importante descrever como foram construídas as relações de confiança da pesquisa.

O modo de condução do dispositivo entrevista pode vir a incorporar e fomentar uma relação de confiança. "Isso significa que a confiança não é um sentimento pessoal, mas sim uma ciência (awareness) que se ancora em um plano comum da experiência" (Sade, Ferraz \& Rocha, 2014, p. 75). É por meio dessa relação que o participante menciona elementos de sua experiência que jamais pensou ou, ainda, vivencia um processo de awareness, por isso é importante preparar o comum da entrevista, colhendo o que foi cultivado. Além disso, em cartografia pode ser interessante compartilhar o problema de investigação, a pesquisadora pode apresentar a sua dúvida para produzir interesse e o/a pesquisado/a passa a ser assumir uma posição de um co-expert. Diante disso, as estratégias desta pesquisa foram pensadas consoante políticas da amizade com pessoas trans e o TCLE foi visto um dispositivo de construção do plano comum que garantiu o protagonismo das/os participantes.

\section{a. Políticas da amizade na prática de pesquisa com pessoas trans}

As políticas de amizade na pesquisa dizem respeito a uma condução de encontros por meio da sintonia afetiva entre sujeitos. Na cartografia, a dimensão do manejo dos vínculos, entre pesquisador e participantes, e as ações conduzidas durante o processo de pesquisa corresponde "tanto ao regime afetivo de articulação quanto à abertura para as transformações decorrentes dessa articulação" (Sade, Ferraz \& Rocha, 2014, p. 69). À primeira vista, pode-se dizer que pesquisadoras/os e participantes tem avaliações, concepções e interesses diferentes ou, até mesmo, 
sobre um assunto relevante à própria pesquisa. Assim, foi pela conquista de relações de confiança que houve a possibilidade de tecer os encontros da pesquisa (um, dois ou três momentos), de modo horizontalizado e co-implicado.

No intuito de produzir zonas de interesse, apesar de possíveis pontos de vista diferentes entre participantes, houve a viabilidade de articular as narrativas que compareceram no campo. A pesquisadora, primeiro, mostrou as suas questões de pesquisa e as/os participantes só puderam se engajar porque sentiram confiança. No primeiro encontro, apresentei o tema de minha tese e disse que visava uma perspectiva psicológica pela despatologização das experiências trans. Por isso, longe de acreditar que neutralidade e objetividade farão com que o pesquisador obtenha informações completas e imparciais, esse procedimento possibilitou que o participante pudesse compartilhar informações de sua história de vida, que são de foro íntimo e que, muitas vezes, lhes causa sofrimento. Diante disso, houve uma partilha entre práticas de resistência, que diz respeito a possibilidade de poder transgredir juntos, a pesquisadora também se mostrou disposta a suscitar questionamentos a um determinado fazer científico em psicologia no seu próprio texto. Então, foi possível a constituição de um plano da experiência compartilhada, "em que as singularidades dos encontros que se fazem presentes no campo concorram para multiplicar as possibilidades de conexões entre sujeitos e mundos" (Sade, Ferraz \& Rocha, 2014, p. 68). O modo de condução das perguntas e o cuidado durante os encontros possibilitou que as entrevistas ocorressem, a partir de uma condução pela amizade, uma vez que "a pesquisa cartográfica opera confiando na potência dos encontros estabelecidos no processo do pesquisar" (Sade, Ferraz \& Rocha, 2014, p. 70). Assim, a amizade teve relação com uma prática de cuidado entre sujeitos, pautado por uma cultura do cuidado de si (ter aceito participar foi uma demonstração de cuidado com a minha pesquisa, e a relação em que as pessoas trans têm é a de uma amizade, de união e de afetividade entre si, por meio do compartilhamento de suas vivências ou de dificuldades).

É importante colocar em evidência uma concepção de intersubjetividade no cuidado de si, pois o outro assume uma inegável importância, seja por meio de um mestre ou um amigo com mais experiência de si. Durante a pesquisa, não houve nenhuma relação de maestria, sobre o que o outro deveria fazer para cuidar de si, mas sim encontros entre co-experts da experiência investigada. Uma vez que um efeito importante de uma cartografia é criar a dissolução do papel hierarquizado da/o pesquisadora/r, não existindo, assim, um objeto de pesquisa a ser representado, sujeitos da pesquisa - participantes e pesquisadores/as - passam a ser concebidos/as como partes constituintes do processo, mesmo ocupando diferentes posições.

\section{b. Linhas de visibilidade do TCLE: sobre o nome próprio}

Para a perspectiva cartográfica, é necessário que pesquisadora/r e praticantes, portanto, encarnem o território da pesquisa e ambos passam a ser interessar pelos seus efeitos, por isso, os 
afetos $^{49}$ da pesquisa precisados ser levados em consideração, pois não é necessário assegurar um plano de representação da experiência ao manter sujeito e objeto como entidades separadas. O que é uma visão bem diferente do modelo representacional de se fazer ciência, uma vez que este visa manter o fato científico purificado. E, assim, usualmente há a preferência de manter a posição de um sujeito anônimo, não dando possibilidade para a visibilidades ou articulações históricas do próprio participante.

Esta pesquisa apresenta como um dos analisadores o fato de que cinco dos seis participantes, no momento de assinatura do Termo de Consentimento Livre Esclarecido (TCLE), não quiseram colocar um nome fictício quando perguntados sobre qual poderia ser o utilizado para que eu pudesse referi-los em minha investigação, mas enfatizaram que eu poderia utilizar o nome que elegeram para si como trans. O dispositivo TCLE promoveu uma outra forma de garantir a legitimidade da escolha de como assinar o próprio nome. Esse acontecimento passou a ser uma questão de análise para esta pesquisa.

Em um primeiro momento, me senti numa posição de ambivalência ética ${ }^{50}$ entre salvaguardar o sigilo pelo anonimato ou promover a visibilidade de suas histórias de vida pela alusão ao nome próprio auto-designado. Segundo os efeitos desse analisador há a emergência de uma dimensão crucial: as/os participantes de minha pesquisa marcam um posicionamento sobre suas memórias e as suas histórias de vida pessoais passam a ser lidas como uma posição social e política no atual momento em que vivemos. Ou seja, para narrar o que pertencem a si (seus segredos, suas confissões ou ainda vivências) almejam uma visibilidade história. A partir dos relatos de cada sujeito, tentou-se produzir um regime de visibilidade sobre os agenciamentos que justificam seus discursos entre a multiplicidade de suas biografias e a história de cada participante vista pelo ponto de vista político-social.

\subsection{Cartografia de práticas de subjetivação}

Neste momento, realiza-se uma cartografia das narrativas produzidas por meio das entrevistas com as/os participantes, em que a proposta é contemplar aos objetivos específicos desta pesquisa como tecer uma análise de práticas que se efetuam pela transgressão às hegemonias pautadas pelas normas de gênero, identificar os argumentos enunciados pelas pessoas entrevistadas para justificar a sua experiência a partir de uma perspectiva de desenvolvimento em psicologia e, além disso, pontuar o que significa, para este estudo, os conceitos de processos de autorreflexividade

49 Afetos, neste contexto, são entendidos como sintonia, emoção, afinidade, incômodo, desconforto, entre outros.

50 Por considerar ainda arriscado, para esta pesquisa, colocar os próprios nomes que os participantes se autodesignaram, e assim escolheram, optou-se por eleger nomes fictícios. Todavia, foi importante pontuar o potencial de discussão desse analisador contido no TCLE, que tem a ver, inclusive, na confiança que os participantes tiveram na produção de efeitos de minha investigação. 
e autorregulação psíquica. Para a realização das análises, esta seção foi dividida em dois momentos, a saber: "narrativas de pessoas trans" e "desenvolvimento, gênero e processos de subjetivação".

Então, esta cartografia sugere uma determinada leitura situada no atual cenário em que estamos e, por isso, concebe um esboço sobre como regimes de verdade podem estar correlacionados com processos de produção da subjetividade, tal como pontua Foucault (1993). Por meio da construção dos analisadores da pesquisa, o intuito foi tecer um diagnóstico provisório de discursos e dos elementos extra-discursivos que os subjazem. Dessa forma, a análise do dispositivo da transexualidade tem evidenciado como as práticas de si podem se desenvolver em técnicas de autoprodução a partir da resistência às hegemonias cisheteronormativas e ao binarismo de gênero.

A partir das entrevistas narrativas e episódicas realizadas, ambas vistas como dispositivos da pesquisa, foi possível observar as experiências de seis pessoas a partir de seus discursos. Nesse sentido, entende-se que a linguagem utilizada na narrativa de si possibilitou observar os possíveis arranjos de processos de subjetivação. É importante também considerar o fato de que podem existir determinados padrões nas narrativas dos participantes. Com base nessa inferência e a partir da afinidade com o conteúdo das entrevistas, foi realizado uma tradução do material ${ }^{51}$ com base em categorias que foram construídas pela pesquisadora e, assim, foi possível realizar uma análise de sentidos e de significados presentes nas narrativas. É importante evidenciar que se tratam de leituras abrangentes, mas não abstratas ou generalizantes, visto que estão contextualizadas às experiências e a um espaço-tempo específicos. As falas do coletivo de entrevistados sugerem uma compreensão sobre as práticas de produção de subjetividade no âmbito das experiências trans.

Nesta pesquisa, os sujeitos foram convidados a relatar as suas próprias histórias de vida. $\mathrm{Na}$ primeira etapa das entrevistas, o intuito foi que cada um dos participantes falasse livremente como se estivesse escrevendo um livro de suas autobiografias. Na segunda, foram escolhidos elementos de suas falas e formuladas perguntas para que cada a/o participante pudesse se aprofundar em pontos específicos. É importante esclarecer que o roteiro previamente estipulado serviu como suporte para as entrevistas episódicas, mas não foi rigorosamente utilizado, pois dependeu de cada caso estudado. Percebeu-se que o roteiro estava muito ligado à etapa do processo transexualizador e dois das/os entrevistadas/os não visavam qualquer modalidade de cirurgia. Decidiu-se, portanto, utilizar perguntas diferenciadas, para estes dois casos, que foram estudadas após a transcrição, e estavam relacionadas às situações apresentadas por cada um dos sujeitos.

A proposta desta cartografia é apresentar o que há de singular em cada experiência e, por isso, esse modo de encaminhar as entrevistas revelou-se essencial. Além disso, entende-se que, pelas

51 Tal como se entendeu no início desta seção que o processo de interpretação se refere ao de tradução, neste caso, das entrevistas. Por sua vez, a categorização diz respeito a como a pesquisadora olha e imprime sua voz nos dados de uma determinada forma. Além disso, a tradução refere-se a um mecanismo de apropriação da palavra do outro que busca um retorno à própria língua, isto é, ao próprio território da pesquisa. 
narrativas, é possível observar como a memória está relacionada aos processos de subjetivação, uma vez que passado e presente passam a coexistir entre si e diz respeito ao modo como as narrativas dos/as entrevistados organizam suas memórias. Essas posicionam as explicações de si na relação com o outro e situam os processos de transição da subjetividade relacionados ao desenvolvimento. Então, o recorte conceitual tem o objetivo de identificar como são construídos os marcadores, em narrativas autobiográficas, para justificar a transgeneridade ou a transexualidade a partir de um olhar centrado numa perspectiva de desenvolvimento em psicologia.

Os/as participantes narraram seu passado e se projetaram no futuro. Por sua vez, o passado constituído pela memória foi concebido no tempo presente. Além disso, pode-se dizer que há um caráter ficcional no conteúdo narrado, que não se deve a imperfeições do relato, mas se referem aos eventos seletivamente lembrados e à produção de sentido, pelo próprio sujeito, que requer mais descrições ou ainda novas leituras. A memória apresenta uma função criativa e é produtora de realidades, de performances ou ainda de modos de subjetivação. De acordo com Deleuze (2006; 2013a), a memória se efetua como concretização no presente ou invocação de um futuro, por isso não é somente um produto de um passado ou, para o contexto das experiências trans, não se reduz somente a infância do sujeito.

\section{a. Narrativas das experiências trans}

Neste contexto, a proposta é apresentar quem são as/os seis participantes com um breve resumo de suas biografias e exposição de seus trechos de fala. Após a familiaridade da pesquisadora com o material, as narrativas foram separadas em cinco eixos relacionados às hipóteses da pesquisa, tais como: 1) autoexplicações; 2) olhar sobre seu desenvolvimento; 3) críticas aos sistemas de gênero; 4) como buscam se inserir e sobreviver ao sistema; 5) conquista de inteligibilidade e formas de resistência a partir de coletivos, amizades, família. Assim sendo, o outro concede um espaço, reconhece, dá inteligibilidade e o sujeito passa a existir com um outro nome e um outro corpo, aqueles que foram entendidos como legítimos para se auto-significar perante às suas relações ou às instituições sociais.

Depois da organização dos relatos, as análises foram sendo realizadas conforme a singularidade de cada uma das entrevistas, observando-se, também, para criar o diagrama da pesquisa, como os processos de subjetivação são produzidos em experiências humanas. Em um primeiro momento, foram descritos breves relatos sobre a experiência de cada participante, depois se recorreu a trechos de suas falas, referentes às autoexplicações e às justificativas sobre desenvolvimento, para, por fim, serem produzidas as análises de cada um. 


\section{Dan}

Dan é um jovem homem trans. Diz ter começado a se identificar com o gênero masculino desde a sua infância. Escolheu um nome fictício que seria utilizado nesta pesquisa. Mostrou-se disponível a participar de três encontros e levou fotos de diferentes momentos de sua vida. À época das entrevistas, estava em processo de terapia hormonal com testosterona havia mais de dez meses, em que buscou acompanhamento com endocrinologista da rede privada, e ainda realizava o acompanhamento psicológico em serviço público de atendimento psicossocial. Também abordou as suas expectativas, que já estava se preparando para a entrada do processo de modificação do nome autodesignado pela defensoria do Estado e para a cirurgia mamoplastia masculinizadora. Dentre suas ambições, destacou-se o desejo de ser feliz, o de construir uma família a que pudesse dedicar seu amor e obter apoio no que diz respeito às suas demandas pessoais e a conquista de respeito pelos seus familiares. Ainda, visava ter um bom emprego, concluir o ensino superior e ter liberdade de ir e vir sem esconder o seu corpo e sua história pessoal, mas, naquele momento, vivia resguardando a sua imagem pessoal pelo fato de sofrer transfobia em sua vida diária, seja no trabalho, no contexto público, ou nas relações interpessoais. Dan justifica a sua transexualidade com conceitos bem definidos e as entrevistas, segundo ele, ofereceu uma oportunidade para uma autorreflexão, pelo fato de poder pensar mais sobre si mesmo. Abaixo serão apresentados trechos de fala, que são vistos como auto enunciativos para a pesquisa, e em negrito significam as falas da pesquisadora:

Melhor começar da parte que eu me identifiquei trans... A melhor forma de se nomear? Um transhomem... na verdade, um homem trans... A diferença é do fato de você se considerar, primeiramente, transexual do que homem. Por exemplo, transhomem, você primeiro se considera um transexual antes de ser homem e um homem trans se considera um homem e depois um transexual, do meu ponto de vista, né?

Como você foi se constituindo a sua masculinidade ao longo da sua experiência?

Ah, eu acho que desde a infância, né? Eu nunca vi um padrão para ser homem ou uma mulher... Então eu acho que do meu ponto de vista não há um padrão pra ser homem ou mulher, você simplesmente, desde a infância eu sempre tive atitude mais masculinas, sempre gostei de jogar bola que, na minha época, que não faz muito tempo assim, a gente sempre tinha essa separação "ah, isso aqui é coisa de menina, isso aqui é coisa de menino" eu nunca gostei de usar roupa feminina, tanto por isso que eu sempre corria praticamente sem camisa o tempo todo, entendeu? Então assim, nunca tive, não sei definir essa diferença de feminilidade e masculinidade, entendeu? Não sei definir a data exata, o momento certo. Então, não tenho essa concepção de momento, acredito que desde quando eu nasci, né? Por não ter esse momento exato de "ah, eu sou homem" (...). É, foi mais ou menos aos 16 anos... é... e assim, momento dificil, adolescência, você não conhece bem as coisas, né? Não sabe como funciona, né? Foi mais aí que eu percebi que tinha algo errado comigo. Que eu não gostava das coisas que aconteciam naqueles momentos. (...) O crescimento de coisas que não eram para ter nascido, outras coisas que deviam ter nascido e não nasceram, né? Tipo assim, os seios, a parte que a gente, que faz a masculinidade, né? Do gênero, né? O gênero, o sexismo, seria mais ou menos isso e a parte assim, que eu fiquei muito indignado, muito triste com o aparecimento dos seios, eu tentava negar de todas as formas, a família pressionando, achando bonitinho e lindo e eu odiando aquilo eu nunca gostei... 
É na parte de se identificar, porque todo mundo, até nesse meio tem um preconceito com quem usa roupa masculina, com quem se trata no masculino, se identifica no meio deles como sapatão macho. (no meio das...?) dos homossexuais, das lésbicas no caso, e ali eu não me encaixava, nunca me encaixei certamente naquele meio e aí conforme o tempo foi passando e eu fui entendendo e aprendendo da vida também, porque eu não sabia nada, não conhecia nada e com o tempo foi passando e eu fui entendendo, até que eu vi uma entrevista do João (W. Nery) na televisão e eu fiquei meio, tipo, encabulado com aquilo que ele disse...

Você lembra o que ele disse? Ele disse que... a primeira coisa dele, a chamada da televisão dizia que a Luciana Gimenez entrevista um homem trans e eu falei assim "pô, que massa véi, vou assistir esse bagulho e ver o que que dá" e ai eu resolvi assistir, eu assisti e ele falava que... ele falou basicamente, porque eu não lembro as palavras corretas, mas mais ou menos isso que o padrão da sociedade poderia mudar, e isso me abriu um pouco os olhos pra eu me entender um pouco melhor, isso eu tinha 16 anos quando vi essa entrevista, né? Aí eu peguei e comecei a pesquisar mais sobre isso, sobre esse padrão da sociedade que poderia mudar, se você nasce num corpo feminino, não é preciso viver com aquilo te angustiando, você pode muito bem mudar e isso me chamou atenção. Fiquei muito feliz quando descobri que poderia sim, ser o que eu achava que eu era desde de pequeno então eu comecei a pesquisar sobre o assunto, não entendo ainda, mas comecei a pesquisar, comecei a ir atrás e saber como, onde, porque e ai eu fui meio que deixando o tempo passar e o tempo passou e sempre me indignando mais com as coisas que aconteciam com o corpo e com o tratamento da pessoas na rua e tal, e aí eu resolvi, no ano de 2010, se não me engano, no ano de 2010 que eu iria sim fazer o tratamento e iria mudar o que deveria já ter nascido comigo, né? Então eu decidi...

Durante a entrevista, busquei assumir uma postura de escuta à história pessoal e posso dizer que acompanhei aspectos ligados à produção da subjetividade, como, no caso específico, envolveu o relato sobre a passagem da utilização do gênero feminino ao masculino para referir a si mesmo. Dan explora o fato de viver a sua transexualidade desde a infância. Um aspecto ainda mais importante refere-se ao momento que assumiu para si a sua condição, que ocorreu na adolescência. É relevante considerar que as transformações corporais, por meio da utilização de hormônios, configuram-se um marco muito importante, porque, para ele, iniciou-se um processo em que passou a ser lido socialmente conforme a auto-expressão de gênero vivenciada.

Relatou a tomada de decisão quanto a assumir-se como trans quando tomou conhecimento da existência do primeiro homem trans no Brasil, João W. Nery, mediante a exposição do autor na mídia ou nas redes sociais. João Nery teve a sua formação em psicologia, mas na década de 70, após a cirurgia da mamoplastia masculinizadora e da retificação do nome nos registros civis, foi impossibilitado ao exercício de sua prática profissional como psicólogo. Hoje se tornou um personagem essencial e atuante na militância social dos homens trans.

Outro fator relevante de análise da fala de Dan se refere ao deslocamento do grupo social de lésbicas, pelo fato de sofrer preconceito da forma masculinizada como expressava seu gênero, na época, como mulher. $\mathrm{O}$ fato de não se sentir incluído o faz se sentir diferente e querer se expressar de outro modo. O grupo social de homens trans surge para dar inteligibilidade social para essa 
experiência.

À primeira vista, pode-se dizer que a transgeneridade e a transexualidade são experiências reveladoras de nosso processo de desenvolvimento cultural da personalidade, uma vez que estão situadas num determinado contexto histórico e social. Nesse cronotopo, há as identificações dos sujeitos entre si a partir de seus relatos autobiográficos. Na busca de integração do eu (self) com a sua expressão e sua materialidade corpóreas, pois há muitos relatos que pontuam a assertiva: "nasci com o corpo errado", os processos de subjetivação em experiências trans são produzidos mediante, em primeiro lugar, uma busca de coerência interna ao sujeito; em segundo, à conquista de um lugar para si na relação com o outro.

\section{Jackie}

Jackie é jovem e uma pessoa trans não-binária. Preferiu utilizar o seu nome social considerado neutro, mas aqui se trata de um nome fictício, escolhido por mim. Utilizo o termo "pessoa", por ele/a não se considerar nem homem e nem mulher ou ainda por performar os dois gêneros ao mesmo tempo. Faz questão de questionar as normas de gênero fabricadas socialmente. Troca as suas vestimentas em cada contexto e faz do seu corpo um ato de liberdade e de manifestação política. Sentiu confiança em mim como pesquisadora e se disponibilizou para vários encontros, houve sintonia e amizade devido ao clima de conversa da entrevista. Introduziu-me ao movimento LGBT do qual ele/a tem participado há dois anos. Fica evidente a forma de como se posiciona em relação às mulheres (de uma valorização das mulheres em sua vida) e menciona a violência de gênero relacionada à interseccionalidade. Nesse sentido, contextualiza as experiências trans de contextos periféricos e a importância da experiência travesti, bicha ou veado, valorizando-as. Jackie opina teoricamente no que diz respeito às relações de poder e de privilégio, inclusive, para situar a sua própria experiência como trans não-binária.

Eu me identifico como uma pessoa trans não binária... eu vou falar naturalmente como se a gente tivesse conversando... uma pessoa que não se identifica dentro da binaridade de gênero. Que não se reconhece dentro da binariedade de gênero que seria homem e mulher. Como eu falei, eu nunca me identifiquei nem como homem e nem como mulher e a primeira vez que eu tive contato com a transgeneridade... humm... da expectometria não binária foi com um caso de uma pessoa não binária que conseguiu o reconhecimento no Canadá. Ela gosta de ser tratada com o pronome no feminino... e... ela conseguiu vencer nos tribunais a identidade de gênero neutra. E eu lendo a matéria, eu... nossa ... eu nunca me identifiquei como homem e como mulher, então... será que eu sou isso? Tipo, agora eu tenho um nome para poder... será que esse é o termo que eu precisava encontrar na minha vida, sabe? A palavra não-binária foi muito depois, o meu primeiro contato foi com gênero neutro. Então, desde então, eu passei a me identificar com o gênero neutro, porque foi o único termo que eu consegui me reconhecer, foi a única ... a primeira forma de expressão de gênero que eu tive para eu me identificar com aquela expressividade, porque eu não me identificava nem como homem nem como mulher. Hoje em dia eu me coloco como uma pessoa não binária, dentro da não binariedade de gênero existem várias variáveis, vários espectros. Então, é muito mais dialogável eu me identificar como não-binária, do que eu me identificar com um 
determinado segmento da binariedade, você falar que é não-binária, as pessoas vão estar cagando para você, porque elas não têm conhecimento sobre a não-binariedade de gênero.

Então, dentro da escola eu sofria muito essa... eu não sabia o que era ser veado, eu não sabia o que era ser bicha. Eu apenas era colocado assim pela minha feminilidade. Por eu ser uma pessoa afeminada, por eu ser o contrário do que os outros meninos eram ou expressavam ser. Eu não entendi porque eu não me expressava daquela maneira, forma, $e$ eu era enquadrado em um outro local, entendeu? Em uma outra tonalidade, isso foi muito choque para mim. Quando eu descobri o que era ser veado, que eu vim ter a percepção de tudo aquilo que eu sofri, sabe? Eu sofri por uma coisa que eu não sabia o que era, entendeu? É muito, é muito agonizante você ser estigmatizada e a primeira coisa que você... a primeira impressão que você tem, nossa... isso deve ser algo ruim. Então, eu não vou tentar ser aquilo que eles estão dizendo que eu sou. Então, como eu vou fazer isso sem saber o que. Você não sabe o que é a palavra, você não sabe o que, porque eles estão te enquadrando na palavra. Ao mesmo tempo você não quer ser isso, mas não sabe deixar de ser isso, pois você não tem conhecimento sobre isso. Porque até então, a gente cresceu em contexto de 2000 até 2007 onde não havia debate sobre orientação sexual, eu vim a ter mais introdução disso depois de 2007, 2008. Dentro da escola, eu não tive debate sobre identidade de gênero e orientação sexual. Ou então questões de gênero mesmo, homem e mulher, porque meio que a sociedade te empurra esses papéis, aí você tem que se virar para cumpri-los. Então, as normas que a sociedade estabelece são as de gênero. E a da heteronormatividade compulsória. Ao meu ver, é o que chegou para mim, as normas de orientação sexual e de identidade de gênero que a sociedade coloca... ou você é homem ou vocé é mulher, ou você precisa ser hetero ou você pode subverter isso, você desestrutura tudo e você vai ser perseguido por isso, você vai sofrer por isso. Você vai sofrer retaliação tanto da família quanto de amigos, quanto das pessoas da própria militância, por incrível que pareça. Ainda tem muita opressão dentro da militância em relação ao gênero e à identidade, orientação sexual nem tanto. Mas identidade de gênero e questões de gênero ainda tem muita.

Na verdade, dentro da não binariedade, também tem os gêneros fluidos que seriam aquelas pessoas não binárias que se fluem entre os dois gêneros da binariedade, no caso homem e mulher. No meu caso, a minha expressão de gênero é um pouco fluida também, só que eu não gosto de me reconhecer dentro de um papel de gênero. Eu não vejo nem como homem nem como mulher, eu não me sinto homem e não me sinto mulher e desde, por exemplo, quando eu era criança, mais ou menos na faixa etária de 9, 10, 11 anos até a minha préadolescência e a minha adolescência, dos doze até os dezessete em que eu estava no ensino médio e ensino fundamental e escolar, eu escutava os meninos, principalmente, a falarem "vira homem" e eu não entendia isso. Eu não entendia o que era ser homem, até hoje eu tenho uma dificuldade do que a sociedade considera como homem, né? A sociedade, claro, que já tem uma norma que estabelece isso, assim como tem normas que estabelecem as mulheres, né? Os papéis que estabelecem em cada um desses gêneros e que tem que cumprir dentro da sociedade, então, esses papéis te determinam se você é homem ou se você é mulher... se você não for de algum desses papéis você está subvertendo todo esse sistema que a sociedade criou para estabelecer o gênero e para monopolizar poderes sobre os corpos.

Desde a escola, Jackie tem sido enquadrada/o por uma palavra que o coloca constantemente em outro lugar. Tratou-se do primeiro momento de exclusão nas sucessivas socializações. O que as relações nessa instituição reforçam são violências contra as expressões de gênero fora das normas a partir da preservação de privilégios de um determinado grupo social (nesse caso, o homem masculino heterossexual cisgênero).

A palavra, seja "veado", "bicha" ou "trans", que, muitas vezes, nem ele mesmo conhece, 
designa-o em uma posição de subalternidade na relação com o outro hegemônico. A força e o modo como essas palavras lhe são colocadas marcam seu corpo, tem o poder de falar sobre quem deveria ser e o sentido que assume, para si mesmo, atravessa a sua experiência de diferentes modos. Nesse sentido, o gênero enquanto um dispositivo discursivo funciona como uma regulação (social e psíquica) que se materializa no corpo, nas práticas sexuais e no processo de apresentação do eu para si e para o outro.

A feminilidade é considerada o outro gênero e uma expressão subjetiva que marca negativamente seu corpo. O que não é estritamente masculino não tem lugar: (neste caso) passa a ser "bicha", "veado", "trans não binário", "não é homem nem mulher”. Nesse sentido, pode-se observar como os processos de produção da subjetividade são agenciados aos sistemas hegemônicos de gênero que lhes são subjacentes, como o binarismo e a cishetenormatividade, em que são efetuadas relações de captura sobre sujeitos considerados diferentes das normas.

Uma vez colocado como diferente, Jackie aprendeu estratégias de como sobreviver à imposição de normas que lhe geram vulnerabilidade, pois passa a ser perseguido e capturado. Por outro lado, a concepção de gênero nesta experiência, em particular, é vivida como fluida, performática e múltipla, a não-binariedade é tecida como uma prática de si e uma ação ética e estética, uma autoprodução. Na contemporaneidade, os sistemas de produção da verdade articulados aos dispositivos de poder sobre o gênero têm sido postos à prova e as/os jovens têm articulado outras formas de dizer e de se expressar como trans.

\section{Roberto}

Roberto se considera um dos primeiros homens trans resignificados do Brasil. Está na meia idade, mas vê com muita esperança seu futuro e a possibilidade de realização da última cirurgia (a construção peniana ${ }^{52}$ ). A sua história se confunde com a sua militância política. Resgata seu passado com saudosismo. Disse-me que poderia utilizar o seu próprio nome na pesquisa, e de novo, por conta do sigilo, elegeu-se um fictício. Tal analisador diz respeito à conquista de visibilidade e legitimidade mediante luta e práticas de resistência: há no próprio nome uma conquista de reconhecimento pelo o que são. Trata-se da produção de uma verdade singular. Disse que dentro do movimento de homens trans tem sofrido um processo de apagamento político, por isso me disse que prefere apresentar a sua história para pesquisadores/as.

Sou um homem definido, me encontro e me sinto, aliás, e afirmo que eu sou um homem hetero. Sou um homem binário, contrariando todos os paradigmas na nova égide de subjetividade de homem trans. Eu sou um homem trans hetero binário, não sou gay, não sou bissexual, não sou pansexual. Tenho a minha identidade de gênero definida de homem.

52 O procedimento cirúrgico consiste na transformação genital e inclui uma vaginectomia, uma reconstrução da parte horizontal da uretra, uma escrotoplastia e uma reconstrução peniana usualmente com um retalho radial do antebraço (ou uma alternativa). Após cerca de um ano, a prótese peniana (ereção) e próteses testiculares podem ser implantadas quando a sensação retornou à ponta do pênis. 
Trabalho, contribuo, voto, tenho família. Sou casado. Na minha infância eu fui criado como um homem. Eu assumo essa identidade política para o empoderamento da militância de homens trans hoje no Brasil, que é muito tenra. A minha transexualidade foi atrasada 30 anos, porque não tinha outros pares no Brasil para que eu me identificasse com a causa.

Eu sempre me enquadrei como homem, mesmo que as pessoas não gostassem, reclamassem, entendeu? Eee... o apagamento político que eu sofro e até no meio de homens trans é porque cada um tem a sua história, né? Eu tenho a minha e cada um tem a sua. Depois do João Nery que apareceu muito tempo depois, eu sou o homem mais velho trans do Brasil. Eu tenho a minha história, e a minha história é a minha história. É claro, que é a minha história individual e coletiva. É claro que essa história não é só minha, senão não seria história. Seria um lamento, então... Mas tem forças políticas, de grupo, que não aceitam com facilidade o meu protagonismo intelectual. Aí vem o apagamento, entendeu? Eu sou mais "respeitado" entre aspas dentro da sociedade do que na comunidade LGBT.

Eu tive a seguinte ideia... Tudo o que não ficar escrito, ninguém vai saber. Eu vou escrever a minha história, só eu. Eu tinha uma máquina de escrever da Olivetti. E eu aprendi a escrever com todos os dedos, porque eu fiz um curso no SENAC. Eu comecei a escrever o meu livro, daí, escutando a música um dia. Já tinha escrito umas páginas, eu fiz tipo um diário. Eu pensava em escrever cada dia os meus sonhos e meus projetos, entendeu? Eu pensava que, mais cedo ou mais tarde, eu iria resolver esse problema de fenótipo, de identidade, de gênero, de documento. Eu sempre quis, sabes o porquê? Porque que o homem não foi a lua, não é verdade? Porque que não faz o que está fazendo hoje a medicina. Bom, o direito estava muito acanhado, os direitos individuais não eram regidos pelo Estado, era um Estado de exceção. Era ditadura naturalmente, ninguém tinha direito a nada, nem liberdade para nada. Eu disse que era militante, e eu já tinha ingressado no Partido Comunista clandestino nessa época.

E, eu, ee... tinha vontade de conversar com alguém, mas conversar com que? Sobre esse assunto? Com ninguém, né? Não tinha ninguém no meu bairro, ninguém na minha casa, ninguém no meu estado, que eu pudesse falar alguma coisa sobre minha identidade. Sobre as minhas aspirações, sobre o meu projeto. E como eu aprendi a escrever bem, eu tinha uma máquina de escrever e comecei a escrever meu livro. O meu diário e comecei a escrever coisas eu que imaginava, como está acontecendo hoje, em relação ao registro civil, casar com uma moça(...).

Roberto passou a constituir a sua masculinidade na década de 1970, 1980, 1990 (ao longo de uma vida) o que significa que os padrões de outrora são diferentes dos de hoje em dia. Trata-se de uma importante linha de análise que é um contraponto entre sua fala e as enunciadas por João ou Jackie. Roberto afirma ser um homem binário (homem masculino) heterossexual, pois assim descreve a sua identidade de gênero e ainda acrescenta que sua expressão como homem trans contraria os novos paradigmas de subjetividade (há um termo que Roberto utiliza e que é importante ressaltar, trata-se do/a pansexual que diz respeito a ter relações afetivo-sexuais com pessoas de todos os gêneros). Será que existe uma resistência do movimento social de homens trans em relação à afirmação da masculinidade de Roberto (da linearidade do homem como masculino)? Essa é a questão que Roberto tem tentado negociar com os seus pares, que, atualmente, também lhe dão inteligibilidade mediante a construção de outras masculinidades possíveis.

No entanto, surge uma tensão entre como negociar o fato de se considerar o primeiro homem 
trans no Brasil, ser militante, ter uma história e contá-la para ser ouvido em sua comunidade e seu próprio grupo. Qual é o seu lugar na história? Qual é o lugar da sua história para si e para o outro? Essas perguntas sugerem possíveis interpretações sobre o que pode significar o apagamento político: a necessidade de contar e recontar a sua história que sugere um anseio por protagonismo, reconhecimento e visibilidade social. Suas narrativas indicam a memória como um olhar entre passado e presente, pois é como vê o seu papel no cenário político de democratização na década de 80 e, atualmente, de luta pelos direitos de as pessoas trans. Escrever a sua própria história é uma possibilidade de conceber a escrita de si como uma estética da existência, uma vez que a tessitura dessa escrita como memória tem lhe conferido um espaço para que possa existir consigo e com os outros. $\mathrm{O}$ ato de lembrar de si passa a ser concebido como um processo ao mesmo tempo singular e coletivo, pois encontra inteligibilidade para a sua história a partir da relação que estabelece entre seus pares.

\section{João}

João é um jovem homem trans binário feminista. Aqui também é utilizado um nome fictício. Considera a constituição de uma outra masculinidade um importante parâmetro para repensamos as nossas relações de gênero. Conforme foi observado pelas suas falas, "o outro", que é significativo para João, designa-o como trans, que, no início, parece lhe soar estranho, mas, com o passar do tempo, ele mesmo passa a se nomear homem trans. Nos últimos anos, passou a participar do movimento social a partir de políticas da amizade, em que tem compartilhado experiências e estratégias de resistência. É a partir desse grupo que passa a se sentir acolhido e valorizado e, por isso, passa a encontrar um lugar para si na relação com o outro. Assumir-se como trans tem o mesmo peso social que o se assumir como homossexual, mas este processo ocorreu primeiro em sua vida e, por isso, vivenciou momentos de exclusão que ocorreram duplamente em sua vida.

Eu entendi o que era a minha identidade de gênero em 2014. Eu estava com 24 anos. Eu entendi que era homem trans, porque antes disso eu não tinha acesso a essa discussão, né? E, tipo, eu passei a entender o que era com uma amiga trans, aí a gente passou a conversar e tal... mas ainda não tinha me tocado sobre o que acontecia. Eu já tinha uma namorada na época, mas a gente estava num momento de crise e daí ela chegou para mim e perguntou, perguntou não, afirmou: "eu acho que você é trans". (...) Eu fiz uma viagem, aí outra amiga minha chegou para mim e disse: "Você é trans?" Ai eu fiquei pensando, cara eu vou correr atrás disso e ver, aí eu comecei a ler (sobre) outros meninos e tal na internet ... eu falei... aí eu fui lendo tipo as histórias, muito parecidas, bem parecidas, né?

Da forma como a gente se sente, por exemplo, eu nunca me encaixei nos grupos de mulheres, eu nunca me senti à vontade quando a gente se reunia em casa, as amigas e tal, depois da bola, ai a gente ficou conversando, tomando... e tal... todo mundo falava sobre as relações, sobre as intimidades... eu ficava deslocado, se eu falasse: "ah assim, assim assado" eu ia me denunciar, entende? Sempre que eu falava uma coisa, assim, ao meu respeito... de comportamento, elas falavam assim... ou quando a gente estava comentando com outra pessoa, ai elas falavam assim: "mas, ah, você pode gostar de mulher sendo mulher, você 
não precisa virar homem". Ai: "ah, não precisa se vestir que nem homem ... não sei o que..." Aí a gente sempre comentava daquelas meninas que eram mais masculinas, que tinham uma postura mais masculina.

Foi logo quando eu assumi que gostava de meninas. Num primeiro momento eu me assumi como homossexual. Era o que eu era, entende? Como homem trans eu pensei em muita coisa, eu pensei em tipo, ah as pessoas vão dizer que eu estou ficando louco, que isso é coisa de louco. E talvez isso não aconteça, pois eu não sou assim... eu preciso virar homem, então... ser como homem e tal... Eu estou tentando encontrar motivos para enfrentar tudo isso de novo, entende? Eu me sentia confortável, mas a possibilidade de ter que passar por preconceito, ter que explicar, que é algo que me deixa desconfortável, às vezes.

Começa pelo fato de, tem várias coisas, quando eu me olhava no espelho eu não me identificava, não reconhecia o rosto que estava ali porque no meu imaginário era um corpo e um rosto diferente, né? Sempre era um choque quando eu me olhava no espelho, porque tinham traços delicados, entendeu? Tinham traços finos do rosto, femininos, então ... e me incomodava bastante, com relação a comportamento, com relação aos papéis de gênero muito bem definidos. (...) O meu comportamento seja socialmente, seja me relacionando com outra pessoa, mas a questão do imaginário da figura masculina, da minha identidade, só foi totalmente construída quando eu entendi o que era. (...) Cara, assim, tem a ver como a gente constrói a nossa masculinidade. É como eu falo, ter uma atitude é diferente de se ver como homem, e você ter uma postura machista perante a sociedade. Ter a sua identidade legitimada, entendeu? A gente precisa separar isso. O que é ser homem, então? Para mim, está muito ligado a questão da identidade, das minhas características físicas, ligado a isso, porque é o meu próprio comportamento. Tanto é que eu brinco com meus amigos assim... vivo fazendo trejeitos e brincando, eu não me importo, tem gente que pensa que eu sou gay.

A linha de análise observada nesta entrevista se refere a como a constituição de gênero é entendida por João segundo sua experiência como homem trans. Nas narrativas, é possível observar como funcionam os processos de autorregulação psíquica no tange à constituição de sua masculinidade ${ }^{53}$, a partir dos diferentes sentidos que esta passa a assumir para ele. Trata-se de um processo que se organiza a partir de uma dinâmica móvel (de fora para dentro da experiência e viceversa) e diz respeito a como as definições de gênero foram sendo modificados na relação com o outro. Além disso, tem a ver com o modo como o olhar para si é moldado através do olhar do outro. Segundo esse processo, ele desenvolve uma concepção singular de masculinidade.

Num primeiro momento, o outro o vê como trans, pois passa a lê-lo segundo signos baseados em expressões corporais e ações ditas masculinas, como, por exemplo, apresentar uma determinada performance, ou ainda, cumprir uma expectativa socialmente construída. Para assumir uma performance social masculina, é importante entender qual é o seu significado; para ele, deriva dos seguintes sentidos: assertividade, tomar atitude na relação, maior poder de decisão e de proteção. Num segundo momento, ele quer "virar homem", mas se questiona como ele se define como homem, pois não almeja reproduzir as relações de poder entre os gêneros. A constituição da masculinidade se deu ao mesmo tempo que participava do movimento feminista, então, passou a se constituir como

53 Na seção seguinte, o conceito de autorregulação psíquica será discutido com mais profundidade baseado na relação entre as análises das entrevistas e o sistema teórico realizado na revisão de literatura. 
tal ao mesmo tempo que desconstruía alguns papéis de gênero, visto que visa negar o machismo na produção de si. A partir daí, tem-se a constituição de uma outra masculinidade: ele se define como homem feminista. E isso implica num terceiro momento: para não reproduzir as relações de subalternidade, ele pontua a importância da feminilidade e das mulheres para constituir a sua própria masculinidade a partir de práticas de resistência.

Atualmente, a constituição de outras masculinidades visa tornar tensa a posição histórica do ser humano hegemônico: o homem masculino heterossexual cisgênero como um sujeito abstrato ausente de gênero. Será que poderia haver outra forma de João ser lido como homem? Poderia ser reconhecido como tal apesar da aparência feminina? Como se estruturaria a relação de poder com os outros gêneros?

Ele relativiza a estrutura rígida relativa ao gênero, visto como papel social, e diz estar mais próximo do referencial masculino. Há um questionamento da identidade de gênero entendida como linear e idêntica ao longo do desenvolvimento. E tal elemento está relacionado com desenvolvimento e temporalidade. Uma vez que recorre ao passado ora como uma forma de explicar o presente, nem sempre se considerou um homem trans, mas, em outros momentos de sua vida, uma mulher homossexual; ora utiliza significantes que reforçam o seu posicionamento atual para justificar a sua transexualidade (ele menciona na entrevista que é transexual). O seguinte relato situa este ponto de argumentação: a infância vista como um menino serelepe, brincava com tudo e todos, na adolescência sentia-se estranho e sozinho, não me encaixava nos grupos. A partir desta entrevista, pode-se observar uma perspectiva de desenvolvimento na constituição de gênero entendida como um evento não linear. Não é a infância que explica a transgeneridade ou a transexualidade. É o relato destas que situa a experiência presente do participante em relação ao seu passado e a memória possibilita a produção de novas subjetivações.

\section{Lee}

Lee (nome fictício) nomeia a si mesmo, atualmente, como uma travesti não-binária devido à dimensão política do termo: Eu me vejo como uma travesti, por ter uma identidade, tenho um terceiro gênero, um gênero a mais. É jovem e tem atuado na militância LGBT. Escolhe as vestimentas com cuidado para cada um de nossos encontros. Ultimamente usa o próprio nome de nascimento, mas em sua forma neutra, além disso, tende a performar a identidade feminina. Em outros contextos, em que quer ser reconhecido no masculino, constrói a sua versão masculina. Ao longo de sua vida, tem vivido um processo de estigmatização, seja na família, seja na escola, pelo fato de se auto-produzir com traços de feminilidade.

Apesar de a minha identidade ser feminina e meu nome ser reconhecido socialmente no masculino, eu tenho apego por ele e não é agora que eu vou querer mudar. Eu não me percebo como gênero neutro ou gênero fluído ou agênero, eu me vejo como uma travesti e por ter uma identidade, eu vejo que eu tenho um terceiro gênero assim. Um gênero a mais, 
mas sendo esse gênero a travesti.

Porque era isso, assim. Porque meu avô foi uma figura muito presente. Ainda é hoje, mas na forma de me controlar, principalmente, na minha infância. Porque ele tinha muito temor de ter um filho ou um neto gay. E não lembro o início de alguma coisa, mas eu sempre me senti atraída pela feminilidade de alguma forma. Eu sempre me senti contemplada pelos trejeitos, pelas ações das mulheres, assim. Eu sempre me liguei muito a isso, e eu sempre quis ser uma delas assim. E aí tinha a figura do meu avô, que ele tinha esse pensamento assim. E como criança que é um sujeito frágil, né? Dentro de várias hierarquias, isso era muito fácil de recair sobre mim. E é mais ou menos assim: esse aperto fez formar a minha identidade, entendeu? Eu não vou falar que é uma coisa que eu nasci com, mas eu acho que foram essas estruturas, desses "apertos" institucionais que tanto da escola, que eu não poderia fazer determinados tipos de brincadeiras, que eu não deveria reagir de determinada formas; que eu não deveria andar com certas meninas, com certos tipos de pessoas; que eu não poderia exercer alguns tipos de atividades, que me levaram a escorrer para um determinado lado assim. Isso formou a minha identidade e eu fui desenvolvendo isso e eu fui interditando alguns momentos da minha vida enquanto eu fui crescendo. E até que eu recuperei tudo isso, assim. No sentido de reinterpretar isso, eu recuperei.

Depois de um tempo, depois da violência que eu sofri tanto em casa quanto na escola, principalmente na escola, eu comecei a ocupar um outro espaço. E sempre que a gente volta nas memórias, é sempre uma reinterpretação que a gente faz, a gente não consegue ver como a gente se sentia, mas tentando perceber isso assim... eu percebi quando as pessoas me colocavam no lugar do veadinho, da bichinha, eu sempre tentava escapar por aquilo, $e$ a forma de eu fugir disso era afirmando uma masculinidade que eu tinha, que eu poderia ter, entendeu? Algum resquício de masculinidade que eu queria provar para eles que eu era um menino, entendeu?

Eu me engajei muito assim... principalmente na militância LGBT desde que eu entrei na universidade. Aí, sempre que eu me apresentava, quando eu falava de mim, eu não usava o termo gay, eu falava que eu era bicha, porque bicha era um termo que poderia colocar o meu corpo numa posição intermediária entre o masculino e o feminino.

Segundo a narrativa de Lee, é possível notar como gênero e os processos de subjetivação são agenciados mutualmente. Devido à profundidade de seus relatos, aparecem elementos relativos à autorregulação psíquica, que se diz respeito a como a constituição de gênero pode ser entendida como um processo dialógico, uma vez que há a construção de significados dentro da narrativa a partir de um diálogo consigo mesmo. Nesse sentido, "bicha" é um ponto chave em sua fala, pois é um termo que adiciona elementos de significação ao longo do seu desenvolvimento.

As características de ser "bicha" conduzem a outros significantes, como, no processo de se tornar outro, passa a se assumir como travesti não binária, pois ambas identidades de gênero são construídas de forma intermediária entre o feminino e o masculino. Trata-se de prática de si relacionada ao gênero que lhe é singular. Neste contexto, é possível observar que o significante "bicha" opera como regulação, o que acontece de fora para dentro da experiência, da não dignidade posicionada pelo outro à autoprodução de si mesmo.

Surge a possibilidade de construir a performance de ser "bicha" como uma estratégia para não tecer uma masculinidade dentro dos padrões binários de gênero, ser não binário é exatamente 
uma forma de exercer uma prática de si como resistência. Além disso, Lee diz que pessoas cisgêneras também podem quebrar a estrutura binária, sendo caracterizada pelo ser "bicha" ou "veado". Podese situar tais processos intermediários de constituição de gênero como performances em práticas de si, daí a importância também da produção de outras feminilidades possíveis: "eu poderia ser até um homem, mas eu não queria estar em nenhum dos papeis desempenhados por um homem, entendeu? E eu me colocava como 'bicha' tentando chegar mais perto da feminilidade".

Há em seu relato a necessidade de reivindicar por meio de grupos, em políticas da amizade, exercícios de transgressão das normas de gênero. Nesses espaços, o sujeito passa a ser visto com dignidade, uma vez que o outro lhe dá um lugar e ambos passam a compartilhar suas experiências mediante uma cultura de si. O grupo a que pertence é um espaço político em que as práticas de si se desenvolvem ainda com mais potência: gêneros não binários e práticas de si em estratégias de resistência aos sistemas de inteligibilidade prévios. Por outro lado, o que é binário está relacionado com temporalidade contínua e linear, identifica-se com essa temporalidade no processo de subjetivação em relação ao gênero. Nesse sentido, as práticas de si não binárias dizem respeito a uma temporalidade não linear em relação ao desenvolvimento de gênero.

\section{Gustavo}

Gustavo (nome fictício) é um jovem homem trans binário pansexual. Diz que se considera como menino desde a sua infância e, desde que mudou da cidade do interior para Brasília, tem feito novas descobertas sobre expressões de gênero e relações afetivo-sexuais. Recentemente, escolheu o seu próprio nome baseado em um amigo de infância construído em seu imaginário. Em sua juventude, este é o nome que escolhe para se apresentar como homem trans em seu grupo de amigos. Para Gustavo, ser homem é se apresentar como másculo, é ter atitude e assumir uma masculinidade, que ele mesmo tenta desconstrui-la. Narra que colegas (homens) não entendem o porquê ele assume uma identidade masculina, mas mantém relações afetivo-sexuais com todos os gêneros; muitas dessas pessoas, ele comenta, fala que para se assumir como homem é preciso gostar (ter relações) apenas de mulheres. Esses termos podem nos dizer sobre o conceito social do que é se apresentar como do gênero masculino, além disso, enuncia que tanto a feminilidade quanto a masculinidade são identificações parciais e produtos de atos performáticos.

Eu sabia que era diferente, mas eu não cheguei a me assumir como lésbica, porque eu não era lésbica. Eu já namorei homens e já namorei mulheres, entendeu? Uma lésbica... até hoje eu sou pansexual, entendeu? Naquela época não tinha, nem falava que eu era bi... eu não falava nada naquela época, ainda mais na cidade do interior. Eu até hoje não lembro, eu não conheço uma pessoa trans na minha cidade. Minha cidade tem 40000 habitantes, eu não sei, não tem caso de outra pessoa trans lá. Tem pessoas que se identificam, eu não tenho precedentes. Aí, entrei na UnB, entrei na sala e dou de cara, descobrindo onde que era, aí, eu vi um casal gay. Aí, aquilo para mim já fui um choque de realidade tremenda. Opa, acho que eu estou no lugar certo, eu passei no lugar certo. Já, tipo, assim, eu não achava estranho, eu achava bonito. 
Tomboy, aquilo dali foi a minha infância. Aquilo dali refletia para mim tudinho. Era eu ali, entendeu? Com aquela roupa de menino, eu só vivia de shortão e camisa suja, eu sujava roupa demais. Eu era menino de rua, então. Aí, que eu comecei a ver, que eu comecei a interagir e, aí, fui encontrando os meninos. Que foi no dia que eu me assumi, só que foi da boca para fora. Que eu era trans, foi um dia que eu estava, que eu tinha ido num evento aqui em Brasília e nudista. Aí, a gente estava voltando desse evento e eu estava no carro, já era uma ex e duas amigas. Ai eu falei... eu assumi e já falei o meu nome, porque quando eu era criança eu tinha um amigo imaginário, aí eu coloquei o nome dele, era o Gustavo. Aí quando eu comecei a entender e comecei a lembrar dessas coisas, eu passei, eu entendi que o Gustavo era uma personificação minha. Isso foi um fato interessante, porque eu tive até a minha puberdade assim, quando comecei a me isolar, começaram a falar... minha mãe até lembra disso, sabe? Que eu contava que eu tinha um amigo imaginário. Eu ficava com ele, né? Porque começaram a me isolar. Eu sofri muito preconceito e eu comecei a brincar com esse amigo imaginário. Aquilo que eu queria ser, eu inventei o Gustavo, era tudo aquilo que eu queria ser. Quando eu falei o meu nome eu nasci de novo, mas como eu não sou assumido para minha família totalmente ainda, só algumas pessoas sabem. Aí, todo o dia eu falo que tenho que matar uma pessoa e levantar um defunto. Eu me escondo, eu meio que me travo. Mas enquanto a minha família não sabe eu vivendo na minha marginalidade, eu vivo fora e dentro do armário. Aí, o trem ia pegar, se eu chegasse em casa com o nome social, se eu pegasse os documentos que eu tenho em casa, o trem ia ficar bonito.

Segundo seus relatos, Gustavo passa a se auto-observar como diferente, em sua comunidade, desde o início de sua adolescência, mesmo não conhecendo os motivos que o levam a se perceber como tal. Há uma sensação de estar deslocado socialmente e, se tornar trans e pansexual, a partir do conhecimento de outras experiências, lhe dá uma inteligibilidade emocional, é como pudesse se compreender (ou se definir) melhor. Tanto a orientação sexual quanto a identidade de gênero podem estar relacionadas a uma dimensão afetiva (até então, inexplicável) para os sujeitos. Ainda, é importante ressaltar que a constituição da feminilidade ou da masculinidade pode ocorrer por meio de identificações parciais do encontro entre o eu do sujeito com o outro.

Além disso, Gustavo não apresenta explicações rígidas sobre os conceitos de gênero, pois, à primeira vista, não tem uma definição do que significa ser homem e ser mulher, apesar de apresentar significados socialmente aceitos sobre o que é ser homem "é ser másculo, é ter atitude". Diz, por outro lado, que se trata de algo que está ligado ao que ele mesmo se identifica (nomeia, designa, compreende), por isso menciona que se identifica com o gênero masculino e, ainda se quisesse, poderia se vestir com roupas femininas: "se eu me sentisse bem e se eu quisesse. Isso não afeta o meu gênero. Não afeta a minha masculinidade".

Dois pontos importantes a ser destacados se referem ao que aconteceu, em geral, com a maioria dos participantes desta pesquisa. Os/as participantes disseram se assumir como homossexual, num primeiro momento de suas vidas, para, depois, se reconhecerem como trans. Essa dimensão diz respeito a um processo de transição entre a concepção de orientação sexual para a seu entendimento sobre constituição relativa ao gênero, mas é importante ressaltar que não se tratam de eventos lineares. Outro ponto diz que a modificação do nome é o primeiro momento de suas transições e assumir seu próprio nome (auto-designado) em público se torna um importante 
acontecimento para eles/as. Nesse sentido, enfatiza-se a necessidade do nome social para a inteligibilidade e respeito, em contextos em que podem (ou querem ser) reconhecidos/as dessa forma, devido à transfobia a que esses sujeitos estão expostos em seus cotidianos e que está generalizada em vários contextos sociais, na família, no trabalho, ou nas relações interpessoais.

Quando Gustavo e os outros cinco participantes da pesquisa narram os acontecimentos de sua experiência, colocam em evidência um evento que lhes é particular e, ao mesmo tempo, é intersubjetivo. Se alguém os chamam de trans, são interpelados e estão abertos a se designar como tais. Na identificação, há uma recusa à unidade do sujeito, pois se identifica a partir de um processo de abertura que é inerente a subjetivação. Neste contexto, é importante fazer uma análise mais abrangente e colocar que, em geral, se refere à produção de subjetividade no que tange às relações estabelecidas entre os sujeitos entrevistados. Butler (1993) diz que há uma ambivalência no evento da "identificação", pois ao mesmo tempo que existe um processo de diferenciação no próprio eu do sujeito, algo se cristaliza no momento da enunciação, e eles/as (os participantes desta pesquisa) escolheram corresponder a esse processo de interpelação.

\section{b. Desenvolvimento, gênero e processos de subjetivação}

Nesta última seção, é realizado um trajeto com base nos indicadores obtidos e gerados pela relação entre os conceitos trabalhos na pesquisa teórica e a análise das entrevistas com cada um/a dos/as participantes. Para a realização do diagrama, foi considerado o conjunto do material estudado e, assim, foi possível discutir sobre como os processos de autorregulação psíquica e autorreflexividade foram compreendidos nesta investigação. Entendeu-se que tais concepções foram ponderadas no intuito de apoiar às questões centrais do estudo: como o gênero participa dos processos de constituição da subjetividade? Como pensar o "desenvolvimento" a partir das práticas de produção da subjetividade na perspectiva da filosofia da diferença?

Nesse sentido, o que a filosofia da diferença oferece à psicologia é um entendimento particular sobre o desenvolvimento de processos de subjetivação, uma vez que foi possível tecê-lo a partir das ideias de Foucault, Deleuze e Butler. Trata-se da concepção de uma perspectiva crítica e processual em psicologia do desenvolvimento. Além disso, outra questão que se visou apontar está relacionada a como o conceito de gênero se articula com processos de constituição da subjetividade. O gênero é, então, um olhar privilegiado para analisar a subjetivação e, por sua vez, a transgeneridade e a transexualidade apareceram como pontos de partida para a análise. Não diz respeito a qualquer subjetividade, mas a como as de experiências trans têm sido constituídas. Assim, torna-se importante colocar em evidência como o gênero participa da formação de sujeitos e, por meio desta abordagem, tem sido o elemento observado a fim de saber como a subjetividade é produzida.

Neste contexto, o gênero foi eleito como uma linha de análise sobre a formação de subjetividades das/os participantes, em que foram feitas as entrevistas, sendo realizadas perguntas 
sobre seus gêneros. Portanto, o que se visou foi uma compreensão sobre como o gênero trabalha para constituir subjetividades no âmbito das pessoas entrevistadas. E isso é parte da cartografia, que precisa ser singularizada, pois cada sujeito tem a sua própria resposta.

Nesse sentido, foi utilizada a filosofia da diferença (Butler, Foucault, Deleuze) para entender as especificidades dos processos e de como acontecem. Trata-se de uma das contribuições para a perspectiva tradicional em psicologia do desenvolvimento, pois o que está em jogo são os processos de subjetivação e suas linhas de forças. Não é apenas um crescimento orgânico ou mental, o que a psicologia do desenvolvimento poderia entender como o desdobramento de um evento que já está contido no indivíduo. Por outro lado, a filosofia da diferença diz que o desenvolvimento pode estar relacionado às interações entre diferentes forças, ou ainda, pode trazer um entendimento específico sobre tempo, por exemplo.

Gênero não é o único trajeto para se entender processos de produção da subjetividade, mas se optou olhar por esse ângulo. A psicologia do desenvolvimento contempla as particularidades de um determinado processo quando observa, prioritariamente, a constituição de gênero na infância. Ao se tomar como exemplo as entrevistas com as pessoas que se tornaram trans, o processo pode também ocorrer quando estão adultas. O que é bem diferente de uma perspectiva de desenvolvimento que privilegia a infầncia no que diz respeito à gênese da constituição de gênero. $\mathrm{O}$ que aconteceu com alguns dos participantes é que pode acontecer tardiamente na vida e eles se projetam de volta para a infância, de acordo com uma estrutura temporal sobre desenvolvimento. No entanto, esse fato desafia a psicologia do desenvolvimento e a ênfase sobre a infância, pois podem também se perceber como trans, a partir de processos de autorreflexividade ${ }^{54}$, quando são adultos. Essa é uma consideração sobre desenvolvimento de gênero que não acontece somente na infância.

Há uma perspectiva de psicologia do desenvolvimento nas entrevistas com os sujeitos sobre a constituição de gênero relativo ao desenvolvimento, que foi entendido como um evento não linear. Não é a infância que explica a transgeneridade ou a transexualidade, mas o relato da infância no tempo presente da/o participante em relação ao seu passado que a justifica. Por outro lado, pode-se dizer que a proposta inicial não foi estudar como essas pessoas se desenvolvem enquanto crianças, mas como adultas/os, enfatizando a narração com marcadores específicos para se auto-explicar: quando crianças, adolescentes, ou adultos, sendo que cada participante pode tecer um olhar diferenciado sobre suas experiências.

Se focarmos apenas na infância, isso significa que para a retificação do nome nos registros civis e a realização da cirurgia de redesignação sexual precisam de um laudo baseado em provas que atestem viver a transexualidade desde o início de suas vidas. Segundo o dispositivo de captura da transexualidade, o conceito "transexual verdadeiro" é utilizado como parâmetro e a experiência de não-conformidade de gênero precisa se manter linear em toda a vida para provar uma determinada

54 Conceito será explicado mais adiante. 
verdade da experiência, sem questionamento. O papel das explicações essencialistas sobre a constituição de gênero é para dar legitimidade a uma determinada forma de viver a transgeneridade e a transexualidade. Há o perigo da legitimação de uma identidade linear, como só os fatos contidos na infância pudessem justificar e comprovar a verdade. Nesse sentido, o problema não é uma concepção de temporalidade no relatório psicológico, mas uma determinada forma de analisar o tempo e a sua relação com o desenvolvimento da subjetividade.

Os sujeitos podem forjar uma compreensão de linearidade da constituição de gênero, baseado em uma perspectiva cronológica de desenvolvimento, uma vez que são interpelados a assegurar uma determinada "verdade" para quem vai escutá-las/os. Em suas narrações, precisam provar que são trans pautados em determinados regimes de verdade. Em geral, as pessoas podem internalizar sistemas de conhecimento para tecer um entendimento acerca de si mesmos, por isso é importante examinar as implicações da psicologia do desenvolvimento quando se trata de gênero e processos de subjetivação, uma vez que diz respeito à produção de verdades específicas e contextuais.

Numa tentativa de recorrer ao passado para laçar respostas à verdade da experiência, convoca-se um tempo estático baseado em uma cronologia linear. Esse é o problema dos relatórios psicológicos que colocam em evidência uma determinada perspectiva de desenvolvimento. No entanto, evoca-se o passado como uma forma de atualizar e explicar o presente, "o passado é virtual e sempre emana ou ilumina o presente" (Deleuze, 2006). Assim, há a necessidade de compreender o tempo como um índice não-linear em psicologia do desenvolvimento, uma vez que é composto por planos heterogêneos, passado e futuro são vistos como dimensões do presente para que as pessoas possam se autoexplicar e elaborar interpretações de si, do outro e do mundo. Não é uma variável independente, tal como alguns autores colocam (Valsiner \& Conolly, 2003), para a pesquisa em desenvolvimento, mas uma variável dependente de outros elementos possíveis, como a constituição de gênero e os processos de subjetivação.

A noção de dobra indica um modo de funcionamento, no caso, da subjetivação humana, por uma duplicidade que lhe é constituinte: o sujeito não é idêntico a si mesmo, é assujeitado aos poderes e aos discursos, mas ao mesmo tempo se produz a partir de resistências aos dispositivos de poder. A diferença repousa no desenvolvimento de si, ao mesmo tempo como mesmo e diferente de si, por isso não há possibilidade de conceber o desenvolvimento sem transição e transformação. Nós nos subjetivamos de formas diferenciadas, a partir de processos de autoprodução, em micro ou macro níveis de desenvolvimento, e as experiências trans evidenciam essa característica própria à subjetivação.

A constituição do gênero vista a partir de temporalidades flexíveis sugere um outro modo de conceber o desenvolvimento de nossas subjetividades. Como nos lemos ou como somos lidos evoca uma perspectiva de como nos subjetivamos de determinada forma e não de outra. Para Halberstam (2005), as pessoas trans podem abrir o potencial de outras narrativas de vida e de relações 
alternativas em relação ao tempo e ao espaço.

Após essas considerações, é apresentado o diagrama do desenvolvimento psicológico numa perspectiva processual a partir da articulação conceitual e da análise das entrevistas. A proposta é explicar pelas narrativas de pessoas trans como se desenvolvem os processos de autorreflexividade e autorregulação psíquica, entendendo a relação de agência, em um co-funcionamento, entre gênero e subjetivação. 
Diagrama 3: Desenvolvimento psicológico numa perspectiva processual.

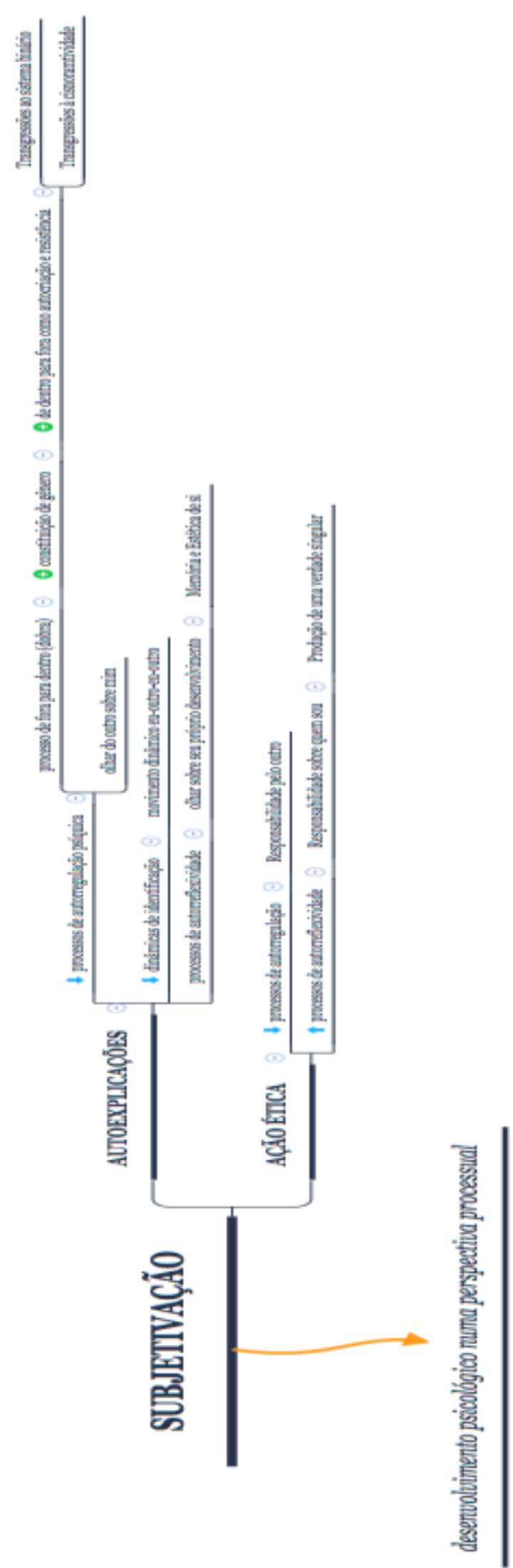


Será feita uma descrição do desenho apresentado acima, em que a parte central do diagrama é o conceito de subjetivação. Trata-se de uma concepção sistêmica para entender o desenvolvimento psicológico numa perspectiva processual. Do conceito de subjetivação surgem duas ramificações: uma diz respeito às autoexplicações das pessoas entrevistadas e a outra foi denominada como ação ética.

Nas narrativas se encontram as autoexplicações quando, por meio das entrevistas, a/o participante faz o relato de si e utiliza termos relativos à primeira pessoa do singular e se explica no intuito de justificar a transgeneridade ou transexualidade, utilizando marcações como "sou", "era", "me identifico", "minha sexualidade", "minha identidade de gênero", "minha transexualidade":

melhor começar da parte que eu me identifiquei trans... (Dan);

Então, eu nunca me identifiquei nem como homem e nem como mulher... (Jackie);

Sou um homem binário, contrariando todos os paradigmas na nova égide de subjetividade de homens trans. Eu sou um homem trans hetero binário, não sou gay, não sou bissexual, não sou pansexual. Tenho a minha identidade de gênero definida como homem (Roberto); A minha transexualidade ... Eu entendi o que era a minha identidade de gênero em 2014. Eu estava com 24 anos. Eu entendi que era homem trans, porque antes disso eu não tinha acesso, éé... a essa discussão, neh? E, tipo, eu passei a entender o que era com uma amiga trans (João);

Apesar de a minha identidade ser feminina e meu nome ser reconhecido socialmente no masculino. Eu não me percebo como gênero neutro ou gênero fluído ou agênero, eu me vejo como uma travesti e por ter uma identidade, eu vejo que eu tenho um terceiro gênero assim. Um gênero a mais, mas sendo esse gênero é a travesti. (Lee);

Eu sabia que era diferente, mas eu não cheguei a me assumir como lésbica, porque eu não era lésbica. Eu já namorei homens e já namorei mulheres, entendeu? Uma lésbica, até hoje eu sou pansexual, entendeu? Naquela época não tinha, nem falava que eu era bi... (Gustavo).

Segundo a fala das/os participantes, a narração de si é uma parte de toda a experiência e as entrevistas mostram um determinado processo de narrá-la. Todas as entrevistas efetuadas dizem respeito às autoexplicações de cada sujeito e a pesquisadora escolheu perguntas que os permitiram abordar sobre os seus processos de identificação e de subjetivação. Nesse sentido, por meio das autoexplicações, foi possível encontrar três dinâmicas: processos de autorregulação psíquica, identificação e processos de autorreflexividade.

A primeira dinâmica se refere aos processos de autorregulação. Foi entendido, por meio das entrevistas, que a regulação psíquica acontece mediante processos que ocorrem de fora para dentro da experiência, por exemplo: "meu corpo é lido de uma forma, eu me comporto de determinada maneira, faço das minhas práticas de si um processo de produção de mim mesmo. Mas alguém me lê o que eu faço de mim mesmo de determinada forma”. Para Butler (1993), há uma relação entre a subjetivação formada por práticas sociais e os processos de interpelação a que as pessoas estão sujeitas.

Nos processos de autorregulação as linhas de análise se bifurcam: "um processo que ocorre de fora para dentro" designa a constituição de gênero e "o olhar do outro sobre mim" pode designar outros processos (que não serão analisados). Neste último, significa que o modo como as pessoas 
olham para o sujeito pode exercer a influência de fazê-lo ser construído de determinado modo, através do olhar do outro, exemplo: "eu construo a mim mesmo nesse sentido, porque eu não estou sozinha/o no mundo, eu estou me construindo como ser humano de determinado modo na cultura, em um espaço-tempo específico". Nesse sentido, entende-se que o processo de constituição de gênero acontece por meio desses processos de autorregulação, porque a dimensão de gênero é situada como produto da cultura, uma vez que nascemos e nos desenvolvemos em um mundo repleto de signos, inclusive, que baseia a divisão binária entre os gêneros pautada na diferença entre os sexos. O gênero é o meio de regulação das práticas sociais e há uma internalização dinâmica desse processo na constituição de subjetividades. Quando passa a ocorrer de dentro para fora é chamado de autoprodução, que não é diferente da autorregulação, mas um produto desta, uma parte do processo de autorregulação é a autoprodução.

Por isso, o processo é dinâmico e se movimenta de forma heterogênea, o que acontece de dentro para fora é de autoprodução, em que é possível se constituir a partir de práticas de resistência contra o sistema binário ou a cisheteronormatividade: "e eu me tornei trans e estou consciente do que sou, embora tenha coragem de viver nesse mundo que é transfóbico, mas esse é o modo em que me tornei e é assim o modo como vejo a mim mesmo".

Nas autoexplicações, existe uma outra ramificação: são os processos de identificação, que também é processo dinâmico e acontece entre os processos de autorregulação e autorreflexividade. Constrói-se a sentença, para exemplificar: "eu admiro você, eu gostaria de ser como você", este é um processo de identificação, em que começa a construir a si mesmo por meio de um processo psíquico em que o outro é projetado como reflexo de mim mesmo. Então, esse é um processo dinâmico entre "eu e o outro", "mim mesmo e o outro", "eu mesmo como outro", "o outro como parte de mim mesmo". Isso acontece com as pessoas trans também e apareceram nas entrevistas. Um exemplo baseado na análise dos resultados: "eu me nomeio como mulher, mas tenho comportamentos de homem eu não sou valorizado como tal em um grupo de mulheres lésbicas. Se alguém me diz: 'você é um trans?’ Após esse processo de interpelação, começo a me perguntar: 'eu sou trans?', 'agora preciso ser homem"'. Isso é algo que acontece entre os processos de autorregulação e os de identificação, porque esse evento de autodescoberta também está relacionado a um determinado modo interpelação pelo outro. Além disso, notou-se a confluência entre tais processos, a partir da narrativa das/os entrevistadas/os, quando observam narrativas situadas no mesmo espaço-tempo que tornam as suas experiências inteligíveis.

Outra ramificação se trata dos processos de autorreflexividade, que deriva da análise dos processos de autoexplicação. É possível observar essa dinâmica quando o sujeito passa a refletir sobre si mesmo e seu próprio processo de subjetivação por meio de práticas de si. Além disso, diz respeito ao modo como a memória trabalha para o sujeito de autoexplicar de determinada forma, por exemplo: o relato sobre a infância ilumina a própria narrativa, em que explica a si mesmo enquanto trans. Assim, no processo de autorreflexividade, há a possibilidade de explicar a si mesmo de 
determinada forma e, neste contexto, é denominado como estética de produção do eu, tal como Foucault (1993; 2010a) assinala. Uma estética de si que diz respeito a como construo um passado coerente ao meu presente.

Para finalizar a descrição, foi observada outra dimensão no processo de análise das entrevistas, diz respeito à ação ética segundo duas ramificações: a autorregulação e a autorreflexividade. De acordo com os processos de autorregulação, as/os participantes são interpelados pela cultura em que estão desenvolvendo a si, segundo o olhar de outros. Existem uma série de sinais em que o outro pode regular, de várias formas. Lee disse que precisa ser responsável pela aparência de seu corpo, pois se um dia decide se apresentar com vestimentas entre o masculino e o feminino, questiona-se qual o banheiro poderia usar. Se decide pelo usualmente utilizado pelas mulheres e sua aparência não está em consonância com o gênero feminino, questiona-se como as mulheres poderiam a/o ver naquela ocasião, uma vez que elas poderiam se sentir ameaçadas. A ação ética parte da transformação da identidade e como isso vai impactar outras pessoas tanto do círculo íntimo, como a família, quanto das relações sociais, em geral, em diversos contextos. João mostra outro exemplo, "não sou um homem cisgênero heterossexual, mas estou construindo a minha masculinidade, não de um modo padrão, eu preciso ser responsável pelo modo como a presença o meu corpo impacta as pessoas, e se alguma mulher se aproxima de mim e estamos no ônibus e nossos corpos estão muito próximos uns dos outros, eu preciso ter cuidado para não mostrar que estou a assediando".

Nesse contexto, observam-se processos de autorregulação, por meio da ação moral sobre si e os outros, que envolve uma responsabilidade no modo como o corpo e o gênero são construídos e traduzidos. Nos processos de autorreflexividade, envolve narrar sobre a experiência da ação ética e significa um processo de reflexão do eu de diferentes modos, em que existem uma série de diálogos internos. Assim, é possível ser responsável por "quem eu sou em relação aos outros" ou "como eu posso construir a verdade da minha experiência". Não se trata de uma verdade estipulada ou normatizada pelos outros ou por regimes de governamentalidades, é por meio da construção de uma verdade singular que é possível tecer a coragem (da verdade) de se dizer trans, porque é assim que o sujeito se experimenta, por meio de uma coerência interna na produção de si. 


\section{CONSIDERAÇÕES FINAIS}

\section{A cartografia de um processo em construção}

Diante de todo o trajeto desenvolvido até o momento, a tessitura das últimas reflexões se produz sobre os acontecimentos da pesquisa: a análise de informações mediante a construção dos dispositivos e de seus desdobramentos em analisadores. Assim, as considerações finais também funcionam como um dispositivo para a emergência de novas problematizações, por isso não são entendidas como um desfecho ou um produto final. A escrita da tese faz operar deslocamentos, uma vez que foi necessário manter a processualidade e os campos de força da pesquisa em todas as etapas do percurso. O que implicou em avaliar a própria prática como um ato de criação e um disparador de efeitos e de implicações para que as/os leitoras/res pudessem acessar e validar à experiência da investigação.

Nesse sentido, essas considerações pautaram-se pelo desenvolvimento de uma cartografia como um processo que ainda pode acompanhar outros caminhos ou propostas. Considera-se importante ter como ponto de partida a construção de análises que possam permitir a transgressão do status quo, que está relacionado a como os regimes hegemônicos de governamentalidade afetam os modos de subjetivação ou ainda as práticas de si. A ideia principal é para não nos basearmos em conhecimentos que visam a manutenção de privilégios, retroalimentam às relações de poder entre grupos sociais e autorizam a sujeição de vidas. Portanto, o conceito de dispositivo da transexualidade utilizado, nesta tese, permitiu que o próprio trabalho pudesse ressoar novos sentidos por meio de linhas propositivas.

Em geral, a conclusão pode ser entendida como um fechamento, um término, para sugerir, de algum modo, uma verdade que se pretende definitiva. Neste contexto, não se trata de substituir uma verdade, sobre o modo de constituição de experiências, por outra, o que significaria apenas trocar as questões de lugar. Ao contrário, por meio de um diagnóstico provisório, este texto se propôs a colaborar com a construção de possibilidades de resistências por meio de novas teorizações. Nesse sentido, compreendeu-se que há uma dimensão da realidade que se apresenta como processo de criação. Por isso, torna-se importante sugerir caminhos em que os resultados e os efeitos gerados pelo trabalho não se esgotem por si mesmos, sendo possível que, até mesmo, os comentários conclusivos possam lançar indicadores.

Durante o percurso, o desenvolvimento de um modo de narrar trouxe profundidade e rigor à investigação, mas também esteve implicado com um processo inventivo. Portanto, rigor e inventividade foram utilizados como parâmetros e envolveu fazer ciência psicológica com a criação de conceitos e também a intervenção sobre a realidade. Entendeu-se que para promover afetos e processualidade durante a leitura da tese, a poiesis foi utilizada como uma política narrativa e se pautou pela arte com a escrita, no intuito de agenciar vida e pesquisa. Ou seja, para trazer fundamento às reflexões, a pesquisadora não quis cumprir receitas ou protocolos prévios baseados pelo simples 
acúmulo de argumentos; de outro modo, se propôs tecer um saber encarnado por meio da escrita como invenção de si, do outro e do mundo.

Stryker (2008) pontua sobre a necessidade de a pesquisa no âmbito dos Estudos Transgêneros estar ligada às inovações tanto teóricas quanto metodológicas, devido às metamorfoses das condições pós-modernas, por isso a proposta metodológica da cartografia para a análise de processos de subjetivação se mostrou significativa. Nesta investigação, foi possível observar as implicações da pesquisadora e das/os participantes no processo de construção do conhecimento com o participar, o conhecer e o intervir, sendo necessário um engajamento do pesquisar com o campo. As resistências das pessoas trans para participarem de pesquisas realizadas por pessoas cis evidencia um rico potencial de discussão, uma vez que historicamente as ciências humanas foram construídas para manter relações de poder e de privilégios. No traçado do plano comum e heterogêneo da pesquisa, as políticas de amizade foram avaliadas com uma possibilidadade da pesquisadora e das/os participantes poderem transgredir juntas/os.

Entendeu-se que o pesquisar pode se tornar mais potente a partir da abertura para uma diferença que perturbe e resista aos modos de ser hegemônicos no intuito de desnaturalizar a norma em prol da busca por caminhos singulares. Por sua vez, o exame da cisgeneridade retira do lugar de "normal" aquele que não é trans e também opera como efeito do dispositivo da transexualidade e, por isso, se efetua nos processos de subjetivação em todos nós. Por isso, foi necessário colocar em análise os campos de força por meio de práticas de resistência, na tentativa de incomodar os centros: às hegemonias cisheteronormativas e ao binarismo de gênero que vem sendo historicamente construídas como naturais e, portanto, se tornam invisibilizados.

A pesquisa trouxe novas considerações sobre as relações entre desenvolvimento psicológico, gênero e processos de produção de subjetividade, em que tomou como parâmetro a luta pela despatologização e a luta pelo direito à saúde. As práticas de resistência enunciam a flexibilidade do gênero e o seu potencial de transformação. As pessoas trans são seres humanos psicologicamente saudáveis, suas articulações políticas e as práticas de si como transgressão são provas disso.

É importante considerar que há um amplo campo a ser explorado entre os Estudos Transgêneros e a Psicologia. Além disso, é importante refletir sobre como promover orientações às/aos estudantes no âmbito formação em psicologia e às/aos respectivas/os profissionais da área, pois há a possibilidade do perigo à precarização da atuação de psicólogas/os, se não alçarmos com profundidade essa discussão. Uma proposta de trabalho sobre a ética do corpo e dos afetos em pessoas trans seria possível e é imprescindível que o debate sobre a hegemonia cisnormativa nos discursos e nas práticas psicológicas se amplie. Traçar novas cartografias sobre as experiências trans pode ser um assunto inesgotável e é importante que seja.

Além disso, tornou-se necessário o questionamento da temporalidade pressuposta em psicologia do desenvolvimento, em suas tentativas de captura da experiência por meio de um tempo linear, estático, único. Um tempo que ainda fecha possibilidades, que exclui diferenças, que cataloga, 
marca, reduz, essencializa. Um tempo concebido como linear se torna insuficiente para o reconhecimento das singularidades e só tende a reafirmar o mesmo, a partir da anulação da alteridade.

Esse é o problema dos relatórios psicológicos que colocam uma perspectiva de desenvolvimento dentro de uma perspectiva temporal estática e linear. Em suas narrativas, as pessoas entrevistadas evocaram o passado como uma forma de atualizar e explicar o presente. Eis a importância de pensar o tempo como não-linear em psicologia do desenvolvimento, mas a partir de planos heterogêneos, passado e futuro são vistos como dimensões do presente para as pessoas que se autoexplicam e tecem interpretações de si e do outro.

A estilística da existência compreende práticas alternativas e modos de compartilhamento e já não mais aquelas formas que representam a captura de modos de vida. As experiências da transgeneridade e da transexualidade abrem o potencial de outras narrativas de vida e relações alternativas em relação ao tempo e ao espaço. Além disso, a cultura de si em práticas de subjetivação em experiências trans produz formas alternativas de temporalidades, permitindo acreditar que futuros podem ser imaginados e vividos como potências de vida. Por meio do tempo e do espaço queer pode ser possível avaliar mudanças culturais e políticas presentes no século XXI. 


\section{REFERÊNCIAS BIBLIOGRÁFICAS}

Agamben, G. (2005). O que é um dispositivo? Retirado de: https://periodicos.ufsc.br/index.php/Outra/article/view/12576/11743.

Allouch, J. (2004). A psicanálise é um exercício espiritual? Resposta a Michel Foucault. Campinas, SP.: Editora Unicamp.

Alvarez, J. \& Passos, E. (2009). Cartografar é habitar um território existencial. In E. Passos, V. Kastrup \& L. Escóssia (orgs.). Pistas do método da cartografia - pesquisa-intervenção e produção de subjetividade. (pp. 131-149). Porto Alegre, RG: Sulina.

Alves, C. \& Delmondez, P. (2015). Contribuições do pensamento decolonial à Psicologia Política. Revista de Psicologia Política, 3 (34).

Ansara, Y. G. \& Hegarty, P. (2012). Cisgenderism in psychology: pathologising and misgendering children from 1999 to 2008. Psychology \& Sexuality, 3 (2), 137-160. doi: http://dx.doi.org/10.1080/19419899.2011.576696.

American Psychiatric Association (2002). DSM-IV. Manual Diagnóstico e Estatístico de Transtornos Mentais. (C. Dornelles, trad., 4a ed.). Porto Alegre, RG: Artmed.

American Psychiatric Association (2013). DSM-V. Diagnostic and statistical manual of mental disorders (5a ed.). Retirado de: http://www.dsm5.org/pages/Default.aspx.

American Psychological Association (2009). Report of the Task Force on Gender Identity and Gender Variance. Retirado de: http://www.apa.org/pi/lgbc/publications/ therapeutic-resp.html.

American Psychological Association (2012). Guidelines for Psychological Practice with Lesbian, Gay, and Bisexual clients. American Psychologist, 67, 10-42. http://dx.doi.org/10/1037/a0024659.

American Psychological Association (2015). Guidelines for Psychological Practice with Transgender and Gender Nonconforming People. American Psychologist, 70 (9), 832-864, doi: http://dx.doi.org/10.1037/a0039906.

Arán, M. (2006). A transexualidade e a gramática normativa dos sistemas de sexo-gênero. Ágora, 9 (1), 49-63.

Arán, M.; Murta, D.; Lionço, T (2009). Transexualidade e saúde pública no Brasil. Ciência \& Saúde Coletiva, 14, 1141-1149.

Arendt, R. J. J. (2016). A escrita como laboratório. Polis e Psiquê, 6 (1), 28-38.

Ariès, P. (1989). História social da criança e da família. Rio de Janeiro, RJ: Guanabara.

Aultman, B. (2014). Cisgender. In P. Currah \& S. Stryker (orgs.). Postposttransexual: key concepts for a Twenty-first-century Transgender Studies, Transgender Studies Quartely, 1, (1-2), 61-62. doi: $10.2015 / 23289252-2399614$.

Austin, J. L. (1975). How to do things with words. (2a. ed.). New York, NY: Harvard University Press. 
Ávila, S. (2014). Transmasculinidades: a emergência de novas identidades políticas e sociais. Rio de Janeiro, RJ: Editora Multifoco.

Bakhtin, M. (2010). Questões de literatura e estética. (7a ed.). São Paulo, SP: HUCITEC Editora.

Bakhtin, M. (2011). Estética da criação verbal (6a. ed.). São Paulo, SP: Martins Fontes.

Barros, L. P., \& Kastrup, V. (2009). Cartografar é acompanhar processos. In E. Passos, V. Kastrup \& L. da Escóssia (orgs.). Pistas do método da cartografia: pesquisa-intervenção e produção da subjetividade (pp. 52-75). Porto Alegre, RG: Sulina.

Barros, L. M. R., \& Barros, M. E. (2014). O problema da análise em pesquisa cartográfica. In E. Passos, Kastrup, V. \& Tedesco, S. (orgs.) Pistas do método da cartografia: a experiência da pesquisa e o plano comum. (pp. 175-202). Porto Alegre, RG: Editora Sulina.

Barthes, R. (1973). Le plaisir du texte. Paris: Éditions du Seuil.

Beauvoir, S. (2009). O segundo sexo. São Paulo, SP: Editora Nova Fronteira.

Benjamin, H. (1966/1999). The transsexual phenomenon. New York, NY: Julian Press.

Benjamin, H. (2006). Transexualism and Travestism as psycho-somatic and somato-psychic syndromes. In S. Stryker \& S. Whittle (orgs). The Transgender Studies Reader. (pp. 45-52). New York, NY: Routledge.

Benjamin, W. (1933/1987). Experiência e Pobreza. In W. Benjamin. Obras escolhidas. Magia e técnica, arte e política: ensaios sobre literatura e história da cultura (pp. 70-79). São Paulo, SP: Brasiliense.

Bento, B. (2006). A (re)invenção do corpo: sexualidade e gênero na experiência transexual. Rio de Janeiro, RJ: GARAMOND/CLAM.

Bento, B. (2008). O que é transexualidade. São Paulo: Brasilense.

Bergson, H. (2011). Matéria e memória: ensaio sobre a relação do corpo com o espírito. (P. Neves, trad.). (4a ed.). São Paulo, SP: Martins Fontes.

Birman, J. (2002). Jogando com a Verdade. Uma Leitura de Foucault. PHYSIS: Rev. Saúde Coletiva, $12(2), 301-324$.

Borba, R. (2014a). (Des)aprendendo a ser: trajetórias de socialização e performances narrativas do processo transexualizador. (Tese de doutorado). Programa de Pós-graduação em Linguística Aplicada, Faculdade de Letras, Universidade do Rio de Janeiro.

Borba, R. (2014b). Sobre os obstáculos discursivos para a atenção integral e humanizada à saúde de pessoas transexuais. Sexualidad, Salud y Sociedad, 17, 66-97.

Borges, L., Canuto, A. \& Oliveira, D. (2013). Abordagens de gênero e sexualidade na Psicologia: revendo conceitos, repensando práticas. Psicologia: Ciência e Profissão, 33(3), 730-745.

Brait, B. (2014). Bakhtin: conceitos-chave. (5a ed.). São Paulo: Contexto.

Burman, E. (2008). Deconstructing Developmental Psychology. London and New York: Routledge.

Burman, E. (2010). Desenvolvimento desejado? Contribuições psicanalíticas para o 
desenvolvimento psicológico. A peste 1(2), 269-294.

Burman, E. (2011). Deconstructing neoliberal childhood: towards a feminist antipsychological approach. Childhood 19 (4), 423-438. doi: 10.1177/0907568211430767.

Burman, E. (2015). Limits of deconstruction, deconstructing limits. Feminism \& Psychology, 25 (3), 408-422. doi: 10.1177/0959353515582274.

Burman, E. (2016). Fanon, Foucault, feminisms: Psychoeducation, theoretical psychology, and political change. Theory \& Psychology, 1-25. doi: 10.1177/0959354316653484.

Butler, J. (1993). Bodies that matter: on the discursive limits of sex. New York, NY: Routledge.

Butler, J. (1997). The psych life of power. Theories of subjection. New York, NY: Stanford University.

Butler, J. (2001). Corpos que pesam: sobre os limites discursivos do sexo. In G. L. Louro (org.). $O$ corpo educado. Belo Horizonte, MG: Autentica Editora.

Butler, J. (2013a). Inversões sexuais. In I. Passos (org.). Poder, normalização e violência: incursões foucaultianas para a atualidade. Belo Horizonte, MG: Editora Autêntica.

Butler, J. (2013b). Problemas de gênero: feminismo e subversão da identidade. Rio de Janeiro, RJ: Civilização Brasileira.

Butler, J. (2015). Relatar a si mesmo, crítica da violência ética (R. Bettoni, trad.). Belo Horizonte, MG: Editora Autêntica.

Candiotto, C. (2007). Verdade e Diferença no pensamento de Michel Foucault. KRITERION, 115, 203-217.

Candiotto, C. (2008). Subjetividade e verdade no último Foucault. Trans/Form/Ação, 31, 87-103.

Carvalho, A. F. (2007). História e Subjetividade no pensamento de Michel Foucault. (Tese de Doutorado). Departamento de Filosofia, Universidade de São Paulo.

Castel, P. H. (2001). Algumas reflexões para estabelecer a cronologia do "fenômeno transexual". Revista Brasileira de História, 21 (41), 77-111.

Castro, L. R. (1992). Desenvolvimento Humano: uma perspectiva paradigmática sobre a temporalidade. Psicologia: Reflexão e Crítica, 5 (2), 99-110.

Cauldwell, D. (1949/2006). Psychopathia Transexualis. In S. Stryker \& S. Whittle. (orgs). The Transgender Studies Reader. (pp. 40-44) New York, NY: Routledge.

Ceccarelli, P. R. (2003). Transexualismo e caminhos da pulsão. Reverso: Revista do Circulo Psicanalítico de Minas Gerais, 25 (50), 37-49.

César, J. M., Silva, F. H., \& Bicalho, P. P. G. (2014). O lugar do quantitativo na pesquisa cartográfica. In E. Passos, V. Kastrup, \& Tedesco, S. (orgs.) Pistas do método da cartografia: a experiência da pesquisa e o plano comum (pp.153-174). Porto Alegre, RG: Editora Sulina.

Cidade, M. L. (2016). Nomes (im)próprios: Registro civil, norma cisgênera e racionalidades do Sistema Judiciário (Dissertação de mestrado). Programa de Pós-graduação em Psicologia, Instituto de Psicologia, Universidade Federal do Rio de Janeiro. 
Conselho Federal de Psicologia (1999). Resolução 001/99. Estabelece normativas de atuação para psicólogos em relação à orientação sexual. Brasília, DF. Retirado de: http://site.cfp.org.br/wpcontent/uploads/1999/03/resolucao1999_1.pdf.

Conselho Federal de Psicologia (2013). Nota técnica sobre processo transexualizador e demais formas de assistência às pessoas trans. Brasília, DF. Retirado de: http://site.cfp.org.br/wpcontent/uploads/2013/09/Nota-técnica-processo-Trans.pdf.

Costa, L. A., Angeli, A. C. \& Fonseca, T. M. G. (2012). Cartografar. In T. M. G. Fonseca (org.). Pesquisar na diferença: um abecedário. (pp. 45-48). Porto Alegre, RG: Sulina.

David-Ménard, M. (2014). Deleuze e a psicanálise (M. J. Moraes, trad.). Rio de Janeiro, RJ: Civilização Brasileira.

Deleuze, G. (1992). Conversações (P. Pelbart, trad.). São Paulo, SP: Editora 34.

Deleuze \& Guattari (1997a). Mil platôs - capitalismo e esquizofrenia (S. Rolnik, trad.). Vol. 4. São Paulo, SP: Editora 34.

Deleuze \& Guattari (1997b). Mil platôs - capitalismo e esquizofrenia (P. Pelbart \& J. Caiafa, trads.). Vol. 5. São Paulo, SP: Editora 34.

Deleuze, G. \& Guattari, F. (2000). Mil Platôs: capitalismo e esquizofrenia (A. G. Neto \& C. P. Costa, trads.). Vol. 1. Rio de Janeiro, RJ: Editora 34.

Deleuze, G. (2003). Qu'est-ce qu'un dispositif. In G. Deleuze. Deux regimes de fous et autres textes. Paris: Minuit.

Deleuze, G. (2004). A Ilha Deserta e outros textos. São Paulo, SP: Editora Iluminuras.

Deleuze, G. (2006). Diferença e repetição (L. Orlandi \& R. Machado, trads.). Rio de Janeiro, RJ: Graal.

Deleuze, G. (2007). Francis Bacon: lógica da sensação (R. Machado, trad.). Rio de Janeiro, RJ: Zahar.

Deleuze, G. (2010). Conversações (P. Pelbart, trad.). São Paulo, SP: Editora 34.

Deleuze \& Guattari (2011). Mil platôs - capitalismo e esquizofrenia (A. Oliveira \& L. Leão, trads.). Vol. 2. São Paulo, SP: Editora 34.

Deleuze, G. (2012). Empirismo e subjetividade: ensaio sobre a natureza humana segundo Hume (L. Orlandi, trad.). São Paulo, SP: Editora 34.

Deleuze, G. (2013a). A imagem-tempo (E. A. Ribeiro, trad.). São Paulo, SP: Brasilense.

Deleuze, G. (2013b). Foucault (C. S. Martins, trad.). São Paulo, SP: Brasilense.

Deleuze, G. \& Parnet, C. (2013). Diálogos. São Paulo, SP: Editora Escuta.

Delmondez, P. (2013). A diferença cultural na escola: uma cartografia de processos de subjetivação de adolescentes e professores/as (Dissertação de mestrado). Programa de Pós-graduação em Processos de Desenvolvimento Humano e Saúde. Universidade de Brasília.

Delmondez, P. \& Pulino, L. H. C. Z. (2014). Sobre identidade e diferença no contexto da educação 
escolar indígena. Psicologia \& Sociedade, 26, 632-641.

Delmondez, P. (2014). Subjetivação e experiência trans: subversões corporais nas práticas de si. Rio de Janeiro: Anais do VII Colóquio de Filosofia da Educação.

Derrida, J. (2008). Da gramatologia. (R. J. Ribeiro, trad., 2a ed.). São Paulo, SP: Editora Perspectiva.

Dickinson, E. (2016). Envelope Poems. New York, NY: Christine Burgin/New Directions.

Dubert, F. (1996) Sociologia da experiência. Lisboa: Instituto Piaget.

Duff, C. (2010). Towards a development ethology: exploring Deleuze's contribution to the study of health and human development. Heath, 14 (6), 619-634.

Edgardo, C. (2009). Vocabulário de Foucault - um percurso pelos seus temas, conceitos e autores. (I. Xavier, trad.). Belo Horizonte, MG: Autêntica Editora.

Escóssia, L. \& Tedesco, S. (2009). O coletivo de forças como plano de experiência cartográfica. In E. Passsos, V. Kastrup, \& L. Escóssia (orgs.). Pistas do método da cartografia: pesquisaintervenção e produção de subjetividade. (pp. 92-108). Porto Alegre, RG: Sulina.

Fausto-Sterling, A. (2012). Sex/gender: biology in a social world. New York, NY: Routledge.

Feinberg, L. (1996). Transgender Warriors: Making History from Joan of Arc to Dennis Rodman. Boston, MA: Beacon Press.

Finn Enke, A. (2013). The Education of Little cis: cisgender and the discipline of opposing bodies. In S. Stryker \& A. Z. Aizura (orgs.). The transgender Studies Reader (pp. 234-247). New York, NY: New Routledge.

Flick, U. (2000). Entrevista episódica. In M. W. Bauer \& G. Gaskell (orgs.). Pesquisa qualitativa com texto, imagem e som: um manual prático (pp. 114-136). Petrópolis, RJ: Vozes.

Fonseca, T. M. G. \& Costa, L. A. (2013). A duração do devir: como construir objetos problema para a cartografia. Fractal, 25 (2), 419-432.

Fornazari, S. K. (2004). O bergsonismo de Gilles Deleuze. Trans/Form/Ação, 27 (2), 31-50.

Foucault, M. (1981). Da amizade como modo de vida. Entrevista de Michel Foucault a R. de Ceccaty, J. Danet e J. le Bitoux. (W. F. Nascimento, trad.) Gai Pied, 25, 38-39.

Foucault, M. (1984). História da sexualidade - o uso dos prazeres. (M. T. Albuquerque, trad., 13a ed.). Rio de Janeiro, RJ: Edições Graal.

Foucault, M. (1985). História da sexualidade - o cuidado de si (M. T. Albuquerque, trad.). Rio de Janeiro, RJ: Edições Graal.

Foucault, M. (1988). A história da sexualidade - vontade de saber. (M. T. Albuquerque \& J. A. G. Albuquerque, trads.). São Paulo, SP: Editora Graal.

Foucault, M. (1993). Verdade e subjetividade. Revista de Comunicação e Linguagem, 1, (19), 203223.

Foucault, M. (1997). Resumo dos cursos do Collège de France (1970-1982). (A. Daher, trad.). Rio de Janeiro, RJ: Zahar. 
Foucault, M. (2000). As palavras e as coisas (S. T. Muchail, trad., 8a ed.). São Paulo, SP: Martins Fontes.

Foucault, M. (2001). Os anormais: curso no Collège de France (E. Brandão, trad.). São Paulo, SP: Martins Fontes.

Foucault, M. (2002). A verdade e as formas jurídicas (R. Machado \& E. Moraes, trads.). Rio de Janeiro, RJ: Nau Editora.

Foucault, M. (2006a). A hermenêutica do sujeito (M. A. Fonseca \& S. T. Muchail, trads., 2a ed.). São Paulo, SP: Martins Fontes.

Foucault, M. (2006b). A Psicologia de 1850 a 1950. In M. Foucault. Problematização do sujeito: psicologia, psiquiatria, psicanálise. (2a ed., pp. 133-151). Rio de Janeiro, RJ: Forense Universitária.

Foucault, M. (2010a). A ética do cuidado de si como prática de liberdade. In M. Foucault. Ética, Sexualidade e Política (pp. 258-280). Rio de Janeiro, RJ: Forense Universitária.

Foucault, M. (2010b). A ordem do discurso. São Paulo, SP: Edições Loyola.

Foucault, M. (2010c). O governo de si e dos outros (E. Brandão, trad.). São Paulo, SP: Martins Fontes.

Foucault, M. (2010d). Em defesa da sociedade (M. E. A. P. Galvão, trad., 2a ed.). São Paulo, SP: Martins Fontes.

Foucault, M. (2011). A coragem da verdade: o governo de si e dos outros II (E. Brandão, trad.). São Paulo, SP: Martins Fontes.

Foucault, M. (2012a). A governamentalidade. In M. Foucault. Estratégia, Poder-saber. (3a ed., pp. 281-305). Rio de Janeiro, RJ: Forense Universitária.

Foucault, M. (2012b). Microfísica do poder (R. Machado, trad., 5a ed.). São Paulo, SP: Graal.

Foucault, M. (2013). A História da Loucura na Idade Média. (J. T. C. Neto, trad., 9a ed.). São Paulo, SP: Editora Perspectiva.

Guattari, F. (1990). As três ecologias (M. C. F. Bittencourt, trad.). Campinas: Papirus.

Guattari, F. (1996). Da Produção de Subjetividade (S. Rolnik, trad.). In A. Parente (org.). Imagem Máquina: A era das tecnologias do virtual (pp. 130-154). São Paulo: Editora 34.

Guattari, F. (2008). Caosmose: um novo paradigma estético (A. L. Oliveira \& L. C. Leão, trad.). São Paulo, SP: Editora 34.

Gurgel, A. (2012). A coexistência entre passado e presente na duração de Henri Bergson. Revista Eletrônica Espaço Teológico, 6 (9), 74-84.

Halberstam, J. (2005). In a queer time and place: transgender bodies, subcultural lives. New York, NY: New York University Press.

Hall, S. (2007). Quem precisa de identidade? In Identidade e diferença: a perspectiva dos estudos culturais. (7a ed., pp.103-133). Petrópolis, RJ: Vozes. 
Haraway, D. (2006). A Cyborg Manifesto: Science, Technology and Socialist-feminism in the late century. In S. Stryker \& S. Whittle. (orgs). The Transgender Studies Reader. (pp.103-118). New York: Routledge.

Haraway, D. (2009). Antropologia do ciborgue (T. T. Silva, trad.). Belo Horizonte, MG: Autêntica Editora.

Harding, S. (1986). The Science Question in Feminism. Ithaca, MA: Cornell University Press.

Henriques, J., Hollway, W., Urwin, C., Venn, C. \& Walkerdine, V. (2002). Selections from Changing the Subject: Psychology, Social Regulation and Subjectivity. Feminism \& Psychology. 2 (4), 427-431.

Hirschfeld, M. (1910/2006). Selections from the Transvestites: the erotic drive to cross-dress. In S. Stryker \& S. Whittle (orgs). The Transgender Studies Reader (pp. 28-39). New York: Routledge.

Honneth, A. (2003). Luta por reconhecimento: a gramática moral dos conflitos sociais. São Paulo: Editora 34.

Houaiss (2012). Dicionário Houaiss: sinônimos e antônimos. São Paulo: Publifolha.

Hur, D. U. (2009). Discursos do trânsito da guerrilha ao Estado neoliberal: estratopolítica, tecnolopolítica e Nomadologia. (Tese de doutorado). Instituto de Psicologia, Universidade de São Paulo.

Hur, D. U. (2013). Memória e tempo em Deleuze: multiplicidade e produção. Athenea Digital. 13(2), 179-190.

Irigaray, L. (1993). An ethics of sexual difference. Ithaca, MA: Cornell University Press.

Jay, M. (2004). Songs of experience: modern American and European variations on a universal theme. Los Angeles, CA: University of California Press.

Jesus, J. G. (2014). Transfobia e crimes de ódio: assassinatos de pessoas transgêneras como genocídio. História Agora, 16, 101-123.

Jesus, J. G; et all (2014). Transfeminismo: Teorias e Práticas. Rio de Janeiro: Metanóia Editora.

Jesus, J. G. (2016a). Operadores do direito no atendimento às pessoas trans. Revista Direito e Práxis, 7, 537-556.

Jesus, J. G. (2016b). Medicina: uma ciência maligna? Debate psicopolítico sobre estereótipos e fatos. Revista Periódicus, 1, 195-204.

Kahhale, E. M. S. P. (2011). Enfrentamento à patologização e a homofobia: Código de Ética do Psicólogo e Resolução CFP 001/1999. Conselho Federal de Psicologia (org.). Psicologia e Diversidade sexual: desafios para uma sociedade de direitos. (pp. 201-126). Brasília, DF.

Kastrup, V. (2007). A invenção de si e do mundo: uma introdução do tempo e do coletivo no estudo da cognição. Belo Horizonte: Autêntica.

Kastrup, V. e Passos, E. (2014). Cartografar é traçar um plano comum. In Passos, E., Kastrup, V., \& Tedesco, S. (orgs.) Pistas do método da cartografia: a experiência da pesquisa e o plano comum (pp.15-41). Porto Alegre, RG: Editora Sulina. 
Kohan, W. O. (2012). Sócrates no último curso de Foucault. In L. Pulino \& S. Gadelha (orgs). Biopolítica, escola e resistência: infâncias para a formação de professores/as. (Vol.1, pp.103118). São Paulo, SP: Editora Alínea.

Krafft-Ebing, R. V. (1893/2006). Psychopathia sexualis with special reference to contrary sexual instinct. A medical-legal study. In S. Stryker \& S. Whittle. (orgs). The Transgender Studies Reader (pp. 21-27). New York, NY: Routledge.

Laqueur, T. (2001). Inventando o sexo: o corpo e gênero dos gregos à Freud. (V. Whately, trad.) Rio de Janeiro, RJ: Relume Dumará.

Larrosa, J. (2014). Tremores: escritos sobre experiência. (C. Antunes \& J. W. Geraldi, trads.) Belo Horizonte: Autêntica Editora.

Lauretis, T. (1987). Technologies of gender - Essays on Theory, Film, and Fiction. Bloomington, IN: Indiana University Press.

Latour, B. (2000). When things strike back: a possible contribution of science studies to the social sciences. British Journal of Sociology, 51 (1), 107-203.

Leite Junior, J. (2008). Nossos corpos também mudam: sexo, gênero e invenção das categorias "travesti" e "transexual" no discurso cientifico. (Tese de doutorado). Programa de Pósgraduação em Ciências Sociais, Universidade Católica de São Paulo.

Lennon, E. \& Mistler, B. J. (2014). Cisgenderism. In P. Currah \& S. Stryker (orgs). Postposttransexual: key concepts for a Twenty-first-century Transgender Studies, Transgender Studies Quartely, 1, (1-2), 61-62. doi: 10.1215/23289252-2399623.

Lionço, T. (2006). Um olhar sobre a transexualidade a partir da tensionalidade somato-psíquica. (Tese de doutorado). Programa de Pós-graduação em Psicologia Clínica e Cultura. Universidade de Brasília.

Lionço, T. (2009). Atenção integral à saúde e diversidade sexual do processo transexualizador do SUS: avanços, impasses, desafios. Physis, 19, 43-63.

Lima, M. F. S. (2010). A construção do dispositivo da transexualidade: saberes, tessituras $e$ singularidades nas experiências trans. (Tese de doutorado). Instituto de Medicina Social, Universidade do Estado do Rio de Janeiro.

Lourau, R. (1993). Análise institucional e práticas de pesquisa. Rio de Janeiro: UERJ.

Mangueira, M. (1997). Empirismo e subjetividade: acerca do pensamento e de alguns princípios ontológicos para uma "psicologia" sem sujeito em Gilles Deleuze. Fractal, 9 (2), 68-82.

Marcondes, D. (2008). Iniciação à história da filosofia: dos pré-socráticos à Wittgenstein. Rio de Janeiro: Jorge Zahar.

Mattos, A. R. (2012). Liberdade, um problema do nosso tempo: os sentidos de liberdade para os jovens no contemporâneo. Rio de Janeiro: Fundação Getúlio Vargas.

Maués, M. (2007). A temática de gênero nas produções provenientes dos grupos de pesquisa da Universidade Federal do Pará. (Dissertação de mestrado). Programa de Pós-graduação em Educação. Universidade Federal do Pará.

Merhy, E. E. (2004). O conhecer militante do sujeito implicado: o desafio de reconhecê-lo como 
saber válido. In T. B. Franco \& M. A. Peres. (org.). Acolher Chapecó: uma experiência de mudança do modelo assistencial, com base no processo de trabalho (pp.21-45). São Paulo: Editora Hucitec.

Money, J. (1969). Sex reassignment as related to hermaphroditism and transexualism. In R. Green \& J. Money (orgs.). Transexualism and sex reassignment. (pp. 40-70). Baltimore: The Johns Hopkins Press.

Morawski, J. G. (1990). Toward the unimagined: feminism and epistemology in psychology. In R. Hare-Mustin \& J. Mareek (orgs.). Making Difference. Psychology and the construction of gender. (pp.150-183). New Hawen, CT: Yale University Press.

Morss, J. R. (1992). Making waves: deconstruction and developmental psychology. Theory and Psychology, 2 (4), 445-465.

Morss, J. R. (2002). Growing Critical: alternatives to developmental psychology. New York, NY: Taylor \& Fancis e-Library.

Murta, D. (2007). A psiquiatrização da transexualidade: análise dos efeitos do diagnóstico de Transtorno de Identidade de Gênero nas práticas de Saúde. (Dissertação de mestrado). Programa de Pós-graduação em Saúde Coletiva. Instituto de Medicina Social. Universidade do Estado do Rio de Janeiro.

Murta, D. (2011). Os desafios da despatologização da transexualidade: reflexões sobre a assistência a transexuais no Brasil. (Tese de doutorado.) Programa de Pós-graduação em Saúde Coletiva. Instituto de Medicina Social. Universidade do Estado do Rio de Janeiro.

Murta, D. (2014). Sobre a apropriação médica da transexualidade e a construção do "transtorno de identidade de gênero": considerações sobre a psiquiatrização das vivências trans. História Agora: a Revista de história do tempo presente, 16, 69-83.

Narvaz, M. (2009). A (in)visibilidade do gênero na psicologia acadêmica: onde os discursos fazem(se) política. (Tese de Doutorado). Programa de Pós-Graduação em Psicologia. Universidade Federal do Rio Grande do Sul.

Nery, J. W. (2011). Viagem solitária: memórias de um transexual trinta anos depois. São Paulo: Leya.

Nietzsche, F. (1873/2007). Sobre verdade e mentira no sentido extra-moral (F. M. Barros, trad.). São Paulo, SP: Hedra Editora.

Nogueira, C. (2001a). Feminismo e discurso do gênero na Psicologia social. Psicologia \& Sociedade, 3 (1), 107-128.

Nogueira, C. (2001b). Contribuições do construcionismo social a uma nova Psicologia de gênero. Cadernos de Pesquisa, 112, 137-153.

Nuernberg, A. (2005). Gênero no contexto da produção científica brasileira. (Tese de doutorado). Programa de Pós-graduação Interdisciplinar em Ciências Humanas. Centro de Filosofia e Ciências Humanas, Universidade Federal de Santa Catarina.

Oliveira, M. J. (2013). Confissões da carne: uma experiência clínica de atendimento psicoterapêutico a transexuais. (Tese de doutorado). Programa de Pós-graduação em Sociologia. Departamento de Sociologia, Universidade de Brasília. 
Oliveira, M. J. (2014). Uma etnografia sobre o atendimento psicoterapêutico a transexuais. Revista Estudos Feministas, 22, 839-862.

Ortega, F. (1999). Amizade e Estética da Existência em Foucault. Rio de Janeiro, RJ: Editora Graal.

Ortega, F. (2002). Genealogias da amizade. São Paulo, SP: Editora Iluminuras.

Passos, E. \& Barros, R. B. (2009). Por uma política da narratividade. In E. Passsos, V. Kastrup \& L. Escóssia (orgs.) Pistas do método da cartografia: pesquisa intervenção e produção de subjetividade (pp.150-171). Porto Alegre, RG: Sulina.

Passos, E. \& Kastrup, V. (2013). Sobre a validação na pesquisa cartográfica: acesso à experiência, consistência e produção de efeitos. Fractal: Revista de Psicologia, 25, 391-413.

Passos, E., Kastrup, V. \& Tedesco. (2014). Pistas do método da cartografia: a experiência da pesquisa e o plano comum. Vol. 2. Porto Alegre, RG: Editora Sulina.

Pelbart, P. P. (2007). O tempo não reconciliado. São Paulo, SP: Perspectiva.

Pelbart, P. P. (2013). O avesso do niilismo: cartografias do esgotamento. São Paulo, SP: n-1 Edições.

Pierce, C. S. (1999). Semiótica (J. T. C. Neto, trad., 3a ed.). São Paulo: Perspectiva.

Porchat, P. (2014). Psicanálise e transexualismo: desconstruindo gêneros e patologias com Judith Butler. Curitiba, PR: Juruá.

Preciado, P. B. (2014). Manifesto contrassexual. (M. P. G. Ribeiro, trad.). São Paulo, SP: n-1 edições.

Prince, V. C. (1980). How to be a Woman, though Male. Los Angeles, CA: Chevalier.

Quijano, A. (2002). Colonialidade, poder, globalização e democracia. Novos Rumos, 17 (37), 1-25.

Rodrigues, S. E. (2009). Subjetividade, tempo e instituição no empirismo transcendental de Gilles Deleuze. Psicologia em Foco, 3 (2), 73-86.

Rose, N. (2011). Inventando nossos selfs: psicologia, poder e subjetividade (A. Arruda, trad.). Petrópolis, RJ: Vozes.

Sabsay, L. (2014). Des-heterossexualizara cidadania é ainda uma frente de batalha (A. Lacombe \& E. Song, trad.). Revista Cult, 193, 30-33.

Sade, C., Ferraz, G. C., \& Rocha, J. M. (2014). O ethos da confiança na pesquisa cartográfica: experiência compartilhada e aumento da potência de agir. In E. Passos, V. Kastrup, \& Tedesco, S. (orgs.) Pistas do método da cartografia: a experiência da pesquisa e o plano comum (Vol. 2, pp. 66-91). Porto Alegre, RG: Editora Sulina.

Safatle, V. (2015). Para um conceito anti-predicativo de reconhecimento. Lua Nova, 1, 79-116.

Salamon, G. (2010). Assuming a body. Transgender and Rhetorics of Materiality. New York, NY: Columbia Press University.

Salih, S. (2012). Judith Butler e a Teoria Queer (G. L. Louro, trad.). Belo Horizonte, MG: Autêntica Editora. 
Scott, J. (1995). Gênero: uma categoria de análise histórica. Educação \& Realidade, 20 (2), 71-99.

Serano, J. (2007). Whipping girl: a transexual woman on sexism and the scapegoating of feminity. Berkeley, CA: Seal Press.

Serano, J. (2013). Excluded: making feminist and queer movements more inclusive. Berkeley, CA: Seal Press.

Silva, T. T. (2007). A produção social da identidade e da diferença. In T. T. Silva (org). Identidade e diferença: a perspectiva dos estudos culturais. (7a ed., pp. 73-102). Petrópolis, RJ: Vozes.

Sperling, D. M. (2003). Arquiteturas contínuas e topologia: similaridades e processos. (Dissertação de mestrado). Programa de Pós-graduação em Tecnologia do Meio Ambiente Construído da Escola de Engenharia de São Carlos. Departamento de Arquitetura e Urbanismo. Universidade de São Paulo.

Stoller, R. (1982). A experiência transexual. Rio de Janeiro: Imago.

Stoller, R. (2006). Selection from biological substrates of sexual behavior. In S. Stryker \& S. Whittle. (orgs). The Transgender Studies Reader (pp. 53-57). New York: Routledge.

Stone, S. (1993/2006). The empire strikes back: a posttransexual manifesto. In S. Stryker \& S. Whittle (orgs). The Transgender Studies Reader (pp. 221-235). New York: Routledge.

STP (2012). Internacional Campaign Stop Trans Pathologization. Reflections on the ICD Revision Process from a Depathologization and Human Rights Perspective. Retirado de: www.stp2012.info.

Stryker, S. (2006). (De)subjugated knowledges: introduction to transgender studies. In S. Stryker \& S. Whittle. (orgs). The Transgender Studies Reader (pp. 1-17). New York, NY: Routledge.

Stryker, S. (2008). Transgender History. Berkeley: Seal Press.

Suess, A. Espineira, K. \& Walters, P. C. (2014). Depathologization. In P. Currah \& S. Stryker (orgs.) Postposttransexual: key concepts for a Twenty-First-Century Transgender Studies. Transgender Studies Quaterly, 1 (1-2), 73-76. doi: 10.1215/23289252-2399650.

Tedesco, S., Sade, C. \& Caliman, L. V. (2014). A entrevista na pesquisa cartográfica: a experiência do dizer. In Passos, E., Kastrup, V., \& Tedesco, S. (orgs.). Pistas do método da cartografia: a experiência da pesquisa e o plano comum. (Vol. 2, pp. 92-127). Porto Alegre: Editora Sulina.

Teixeira, F. (2009). Vidas que desafiam corpos e sonhos: uma etnografia do construir-se outro no gênero e na sexualidade. (Tese de doutorado). Programa de Pós-graduação em Ciências Sociais, Instituto de Filosofia e Ciências Humanas. Universidade Estadual de Campinas.

Valsiner, J. \& Connolly, K. (2003). Introduction: The nature of Development: the continuing dialogue of processes and outcomes. In J. Valsiner \& K. Connolly (orgs). Handbook of Developmental Psychology (pp.1-13). London: Sage Publications.

Veiga-Neto, A. (2003). Cultura, culturas e educação. Revista Brasileira de Educação, 23 (2), 5-15.

Vergueiro, V. (2015). Por inflexões decoloniais de corpos e identidades de gênero inconformes: uma análise autoetnográfica da cisgeneridade como normatividade. (Dissertação de Mestrado). Programa Multidisciplinar de Pós-graduação, Cultura e Sociedade. Universidade Federal da Bahia. 
Walkerdine, V. (1993). Beyond developmentalism? Theory and Psychology, 3, 451-469.

Walkerdine, V. (2013). Using the Work of Felix Guattari to Understand Space, Place, Social Justice, and Education. Qualitative Inquiry, 19 (10), 756-764. doi: 10.1177/1077800413502934.

Woodward, K. (2007). Identidade e diferença: uma introdução teórica e conceitual. In T. T. Silva (org). Identidade e diferença: a perspectiva dos estudos culturais (7a ed., pp.7-72). Petrópolis: Vozes.

Wittig, M. (1992). The Straight Mind and other essays. Boston, MA: Beacon Press.

Zambrano, E. (2003). Trocando os Documentos: Um Estudo Antropológico sobre a Cirurgia de Troca de Sexo. (Dissertação de Mestrado). Instituto de Filosofia e Ciências Sociais, Universidade Federal do Rio Grande do Sul.

Zambrano, E. (2011). Transexuais: identidade e cidadania. In G. Venturi \& V. Bokany (orgs.). Diversidade e Homofobia no Brasil (pp. 97-108). São Paulo: Editora Fundação Perseu Abramo.

Zourabichvili, F. (2016). Deleuze: uma filosofia do acontecimento (L. Orlandi, trad.). São Paulo: Editora 34. 


\begin{abstract}
ANEXOS
Anexo. 1

Roteiro de entrevista

Entrevista com pessoas transexuais divididas em dois momentos. No primeiro dia o objetivo é que a pessoa possa relatar livremente através da entrevista narrativa, no segundo, o objetivo é que aprofunde temas previamente selecionados pela pesquisadora.
\end{abstract}

\title{
Primeiro momento: entrevista narrativa
}

Nossos encontros serão divididos em dois dias. No primeiro momento o objetivo é que você possa falar livremente como se estivesse narrando a sua história para escrever sua própria biografia, ou seja, um livro sobre a sua própria história de vida. Depois você pode ter acesso a esse material transcrito. No segundo farei perguntas mais específicas e gostaria que trouxesse fotografias de sua vida (infância, adolescente e idade adulta). Você quer começar?

\section{Segundo momento: entrevista episódica}

(retomar elementos ressaltados na entrevista narrativa e aprofundá-los)

1) Pedir para trazer objetos e fotografias de várias etapas do desenvolvimento e descrevê-los;

a) Conversar sobre cada foto, porque escolheu cada foto e o que tem para dizer sobre cada foto.

b) Se você fosse tirar foto de você daqui a tantos anos como você se imaginaria nessa foto.

2) Como você foi constituindo a sua feminilidade/masculinidade ao longo da sua experiência transexual

a) Quando começou a se tratar no masculino/feminino?

b) O que é ser homem/mulher para você?

c) E no seu processo transexualizador;

d) Contem-me três exemplos que achou mais marcante nesse processo; 


\section{Anexo 2. Termo de Consentimento Livre e Esclarecido (TCLE)}

Você está sendo convidado a participar da pesquisa "A constituição da identidade de gênero na experiência transexual", de responsabilidade de Polianne Delmondez, aluna de doutorado em Psicologia pela Universidade de Brasília. O objetivo desta pesquisa é analisar como as/os transexuais dão sentido a sua experiência de subjetivação, ou seja, como constroem significações acerca de si e de seu processo de definição da identidade de gênero. Assim, gostaria de consultá-lo(a) sobre seu interesse e disponibilidade de cooperar com a pesquisa.

Você receberá todos os esclarecimentos necessários antes, durante e após a finalização da pesquisa, e lhe asseguro que o seu nome não será divulgado, sendo mantido o mais rigoroso sigilo mediante a omissão total de informações que permitam identificá-lo(a). Os dados provenientes de sua participação na pesquisa, tais como questionários, entrevistas, fitas de gravação ou filmagem, ficarão sob a guarda do pesquisador responsável pela pesquisa.

A coleta de dados será realizada por meio de pesquisa documental, observação exploratória e entrevistas narrativas e episódicas. Para os procedimentos relativos às entrevistas você está sendo convidado a participar. Sua participação na pesquisa não implica em nenhum risco.

Espera-se que esta pesquisa contribua para uma compreensão acerca dos processos de subjetivação e de identificações na transexualidade, a partir dos resultados objetiva-se a inovação das técnicas de atendimento psicológico para as pessoas trans.

Sua participação é voluntária e livre de qualquer remuneração ou benefício. Você é livre para recusar-se a participar, retirar seu consentimento ou interromper sua participação a qualquer momento. A recusa em participar não irá acarretar qualquer penalidade ou perda de benefícios. Se você tiver qualquer dúvida em relação à pesquisa, você pode me contatar através do telefone (61) 81196369 ou pelo e-mail polianne.delmondez@gmail.com.

A pesquisadora garante que os resultados do estudo serão devolvidos aos participantes por meio da entrega de uma cópia da tese defendida à instituição (com previsão de defesa para dezembro de 2016), podendo ser publicados posteriormente na comunidade científica.

Este projeto foi revisado e aprovado pelo Comitê de Ética em Pesquisa do Instituto de Ciências Humanas da Universidade de Brasília - CEP/IH. As informações com relação à assinatura do TCLE ou os direitos do sujeito da pesquisa podem ser obtidos através do e-mail do CEP/IH: cep_ih@unb.br.

Este documento foi elaborado em duas vias, uma ficará com o(a) pesquisador(a) responsável pela pesquisa e a outra com você.

Assinatura da/o participante

Assinatura da pesquisadora

Brasília, de de 